ANDRÉ LUIZ MARGUTI

EFEITO DO RECEBIMENTO DE LODOS ORIUNDOS DE ESTAÇÕES DE TRATAMENTO DE ÁGUA NOS PROCESSOS DE TRATAMENTO DE ESGOTOS POR LODOS ATIVADOS CONVENCIONAL 


\title{
EFEITO DO RECEBIMENTO DE LODOS ORIUNDOS DE ESTAÇÕES DE TRATAMENTO DE ÁGUA NOS PROCESSOS DE TRATAMENTO DE ESGOTOS POR LODOS ATIVADOS CONVENCIONAL
}

\author{
Dissertação apresentada à Escola \\ Politécnica da Universidade de São \\ Paulo para a obtenção do título de \\ Mestre em Engenharia
}

Área de concentração: Engenharia Hidráulica e Sanitária

Orientador: Professor Livre-Docente Sidney Seckler Ferreira Filho 
Este exemplar foi revisado e alterado em relação à versão original, sob responsabilidade única do autor e com a anuência de seu orientador.

São Paulo, de junho de 2012.

Assinatura do autor

Assinatura do orientador

FICHA CATALOGRÁFICA

Marguti, André Luiz

Efeito do recebimento de lodos oriundos de estações de tratamento de água nos processos de tratamento de esgotos por lodos ativados convencional / A.L. Marguti. -- ed.rev. -- São Paulo, 2012.

222p.

Dissertação (Mestrado) - Escola Politécnica da Universidade de São Paulo. Departamento de Engenharia Hidráulica e Ambiental.

1.Tratamento de esgotos sanitários 2.Disposição de lodos de estações de tratamento de água 3.Lodo ativado I.Universidade de São Paulo. Escola Politécnica. Departamento de Engenharia Hidráulica e Ambiental II.t. 
À minha avó Josina, para quem eu já era doutor. 


\section{AGRADECIMENTOS}

Meus agradecimentos a todos àqueles de alguma forma contribuíram para a realização deste trabalho e conclusão de mais esta etapa na minha evolução, em especial:

Aos meus queridos pais Aparecido e Adguimar, por toda dedicação, apoio e incentivo em toda vida, sendo desde sempre minha base e porto seguro. Estendo este agradecimento às minhas irmãs Elaine e Letícia, cunhados Rodrigo e Rafael, sobrinhos Luísa e Eduardo, e demais familiares.

Ao orientador Prof. Dr. Sidney Seckler, que me acompanha desde a graduação, sempre me guiando com conselhos não só para a vida acadêmica, mas também profissional e pessoal.

A todos os funcionários da SABESP pela possibilidade de realização deste trabalho em suas instalações, em especial à Magda Carvalho e à Sheila Oliveira, representando o pessoal da ETA Rio Grande e da ETE ABC, respectivamente.

Aos amigos e companheiros de jornada do mestrado Bruno Chieregatti e Fernanda Belizário, pelos momentos de suporte, desabafos mútuos e trabalho conjunto.

Às amigas Mila Amaro e Juliana Kawahashi pelo companheirismo inquestionável durante todos os momentos, compartilhando desde as melhores alegrias quanto as piores situações.

Aos demais amigos, que sempre me incentivaram e acompanharam, não só neste trabalho como em todos os outros já realizados, bem como pelos momentos de descontração fundamentais para a finalização saudável desta etapa: Maria Cristina Pereira, Silvia Oliveira, Diego Tietz, Thiago Zanon, Patricie Barricelli, Vitor Oliveira, Rafael Soliaman, Ana Fernandes, Clarissa Yebra, Suyami Maruyama, Diego Carreras e Talita de Andrade.

À amiga Renata Monte, por toda ajuda sobre a pós-graduação, principalmente pelas estatísticas e pelo conhecimento do CEA, incluindo neste agradecimento profa . Lane,

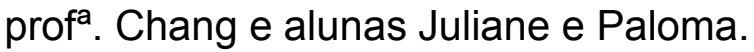


Aos professores da Escola Politécnica, com destaque aos docentes do PHD, prof. Dr. Pedro Alem Sobrinho, prof. Dr. Roque Passos Pivelli, prof ${ }^{a}$. Dra. Dione Morita e prof. Dr. Mario Thadeu.

À ETEP, por me possibilitar a realização deste mestrado concomitantemente à execução de seus projetos. Em especial, meus sinceros agradecimentos aos eng ${ }^{\circ \text {. }}$. Hildebrando Vasconcellos, José Luiz Prado e Bruno Hespanhol, pelo compartilhamento diário de suas vastas experiências, tanto técnica quanto de vida.

E a todos aqueles que de alguma forma tornaram possível mais essa conquista em minha vida, meu mais sincero muito obrigado! 
“Nascer, morrer, renascer ainda e progredir continuamente, tal é a lei."

(Allan Kardec) 


\section{RESUMO}

Por razões técnicas e ambientais, o lodo gerado no tratamento de águas para abastecimento público deve ser adequadamente tratado antes de ser disposto no meio ambiente. Uma alternativa é a disposição do lodo de ETA em ETE, o que dispensa a implantação da linha de tratamento do lodo na ETA. O objetivo deste trabalho foi estudar os impactos ocorridos na ETE $A B C$, estação de lodos ativados convencional operada pela SABESP, devido ao recebimento do lodo da ETA Rio Grande. Trata-se de caso particular, pois envolve instalações reais, e pelo fato de a ETA apresentar vazão próxima de três vezes a vazão da ETE (vazão de lodo corresponde a $0,1 \%$ da vazão da ETE). Os dados utilizados incluem variáveis de qualidade do efluente (DBO, DQO, SST, SSV, nitrogênio amoniacal e total, fósforo e ferro) e do lodo (sólidos), e parâmetros operacionais das unidades da ETE (vazões, taxas de aplicação superficial e de sólidos, idade do lodo, tempo de detenção, entre outros). Foi possível analisar o processo de tratamento na ETE e comparar seu desempenho entre dois períodos: "controle" (anos de 2005 e 2006) e com lodo (janeiro de 2007 a março de 2008). Nestes períodos, a ETE operou com $50 \%$ de sua capacidade (taxas de aplicação abaixo dos valores de projeto), idade do lodo de 4 dias e taxa de reciclo em torno de $80 \%$. No período com lodo, as variáveis que apresentaram maior aumento de concentração no esgoto afluente foram SST, SSV, fósforo e ferro; o lodo da ETA contribuiu para maiores eficiências de tratamento da fase líquida na ETE, uma vez que houve a manutenção da qualidade do efluente final, nos níveis exigidos pela legislação, mesmo com o aumento das concentrações afluentes. Este aumento de eficiência foi mais acentuado para o fósforo (de $52 \%$ para $88 \%$ ), e maior no tratamento primário, com variações nos parâmetros operacionais que não influíram negativamente no desempenho das unidades. No tratamento de lodo, o maior impacto causado foi o aumento na produção final de lodo (de $50 \mathrm{t} / \mathrm{d}$ para $76 \mathrm{t} / \mathrm{d}$ ). Tais conclusões são então favoráveis ao lançamento de lodos de ETA convencional em ETE de lodos ativados convencional, mesmo nos casos em que a vazão tratada na ETA exceda em muito a vazão da ETE.

Palavras-chave: Lodo de ETA. Lodos ativados. Tratamento de lodos. 


\section{ABSTRACT}

For technical and environmental reasons, sludge from water treatment plants should be properly treated before being discharged into the environment. An emerging practice is the disposal of such sludge in WWTP, an alternative that does not require the installation of sludge treatment facilities in the WTP. The main purpose of this research was to study the impacts at the ABC WWTP, an activated sludge process facility operated by SABESP and located in São Paulo, Brazil, due to receiving sludge from the Rio Grande WTP, also located in the same region. It is a particular case due to the fact that the WTP provides a flow of three times the flow treated in the WWTP (sludge flow is $0,1 \%$ of WWTP flow). The used data include effluent quality variables (BOD, COD, TSS, VSS, ammonia and total nitrogen, phosphorus and iron), sludge (solids) and WWTP units operational parameters (flow, surface and solid application rates, sludge retention time, hydraulic detention time, among others). It was possible to analyze the treatment process at the WWTP and compare its performance between two periods: "control" (years 2005 and 2006) and "with sludge" (from January 2007 to March 2008). In these periods, the WWTP worked with half of its capacity (all loading rates stayed below design values), sludge retention time of 4 days and recycle rate around $80 \%$. In the "with sludge" period, the quality variables with the highest inflow concentration increase were TSS, VSS, phosphorus and iron. During the same period, the WTP sludge contributed to greater efficiencies in the WWTP treatment process, since the effluent quality was maintained under levels legally required, even with the increase of influent concentrations. This fact is mostly evident in the case of phosphorus (from $52 \%$ to $88 \%$ ), and higher in primary treatment, with changes in operational parameters that did not adversely affect the units performances. In solid phase treatment, the most important impact was the increase in final sludge production (from $50 \mathrm{t} / \mathrm{d}$ to $76 \mathrm{t} / \mathrm{d}$ ). These conclusions are then favorable to the disposal of sludge from conventional WTP in an activated sludge WWTP, even in cases in which the flow treated in the WTP far exceeds the WWTP flow.

Keywords: WTP sludge. Activated sludge. Sludge treatment. 


\section{LISTA DE FIGURAS}

Figura 1 - Resíduos produzidos em ETA do tipo convencional. (Fonte: Cordeiro, 1999).

Figura 2 - Processo de lodos ativados e geração de resíduos. (Fonte: ANDREOLI et al., 2001).

Figura 3 - Captação de água bruta da ETA Rio Grande. 21

Figura 4 - Vista aérea da ETA Rio Grande. 21

Figura 5 - Fluxograma esquemático da ETA Rio Grande 22

Figura 6 - Chegada da água bruta na ETA, com aplicação de produtos químicos...23

Figura 7 - Floculadores hidráulicos da ETA Rio Grande. 23

Figura 8 - Decantadores da ETA Rio Grande. 24

Figura 9 - Água decantada. 24

Figura 10 - Filtros da "ala velha" da ETA Rio Grande. .25

Figura 11 - Floculadores mecanizados da "ala nova" da ETA Rio Grande. .26

Figura 12 - Decantadores de fluxo laminar da "ala nova" da ETA Rio Grande... 26

Figura 13 - Canal e tubulação de coleta de lodo. 27

Figura 14 - Calhas de coleta dos novos filtros da ETA Rio Grande. 27

Figura 15 - Retrolavagem dos novos filtros da ETA Rio Grande. 28

Figura 16 - Novos reservatórios de água de retrolavagem. 28

Figura 17 - Vista geral do Reservatório de Lodo. 29

Figura 18 - Lodo armazenado no reservatório. 29

Figura 19 - Vista aérea da ETE ABC 30

Figura 20 - Fluxograma esquemático da ETE ABC 32

Figura 21 - Instalações de gradeamento. 33

Figura 22 - Caixa de areia aerada. 33

Figura 23 - Clam-shell para retirada de areia. 34 
Figura 24 - Decantador primário vazio, para limpeza e manutenção. 34

Figura 25 - Decantador primário em operação.

Figura 26 - Tanque de aeração inoperante da ETE ABC.

Figura 27 - Vista geral de um decantador secundário da ETE ABC .....................36

Figura 28 - Detalhe da saída de efluente final, clarificado, da ETE ABC...............36

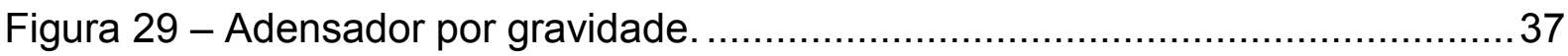

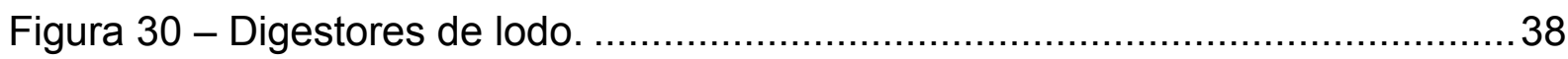

Figura 31 - Silos para armazenamento de cal. ......................................... 38

Figura 32 - Canal de recalque para o tanque de condicionamento. ..................... 39

Figura 33 - Instalações de aplicação de produtos químicos no condicionamento do lodo da ETE ABC. ............................................................... 39

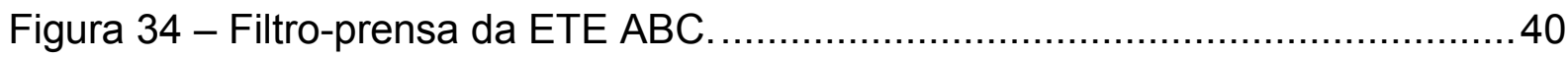

Figura 35 - Torta desidratada, pronta para disposição final em aterro. .................40

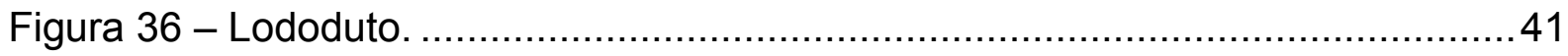

Figura 37 - Produção média diária por mês de lodo na ETA Rio Grande durante o período de estudo............................................................. 50

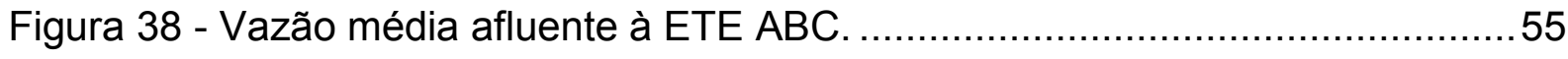

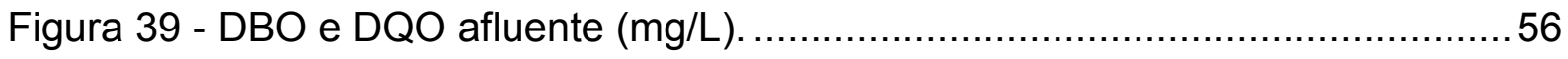

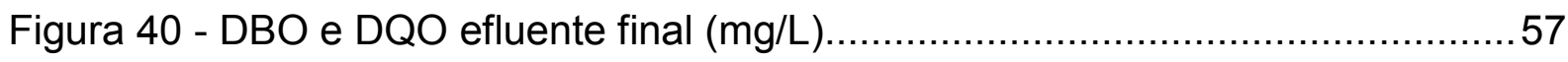

Figura 41 - DBO e DQO: Eficiência de remoção total na ETE ABC (\%). ................58

Figura 42 - Série de valores - DBO e DQO no esgoto afluente e no efluente final da

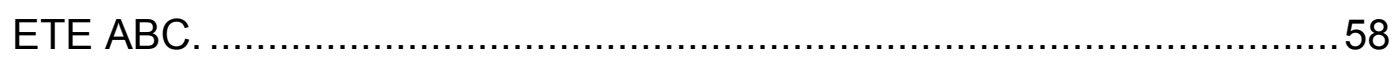

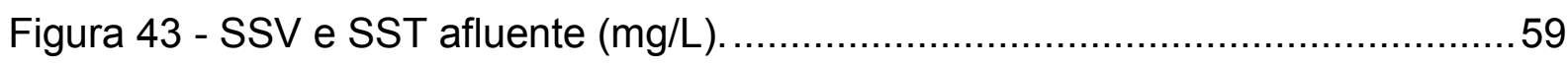

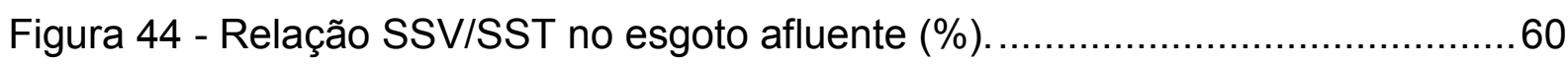

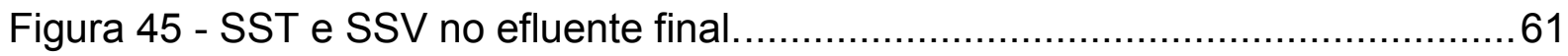

Figura 46 - SST e SSV: Eficiência de remoção total na ETE ABC (\%). ..................62 
Figura 47 - Série de valores - SST, SSV e relação SSVISST no esgoto afluente e efluente final da ETE ABC.

Figura 48 - NTK e Nitrogênio Amoniacal afluente (mg/L)................................63

Figura 49 - NTK e Nitrogênio Amoniacal efluente final $(\mathrm{mg} / \mathrm{L})$. ..........................64

Figura 50 - NTK e N-NH3: Eficiência de remoção total na ETE ABC (\%). ................64

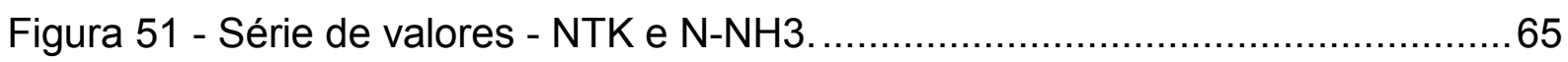

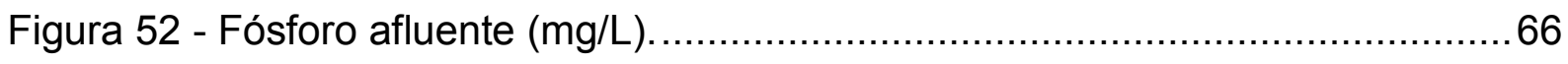

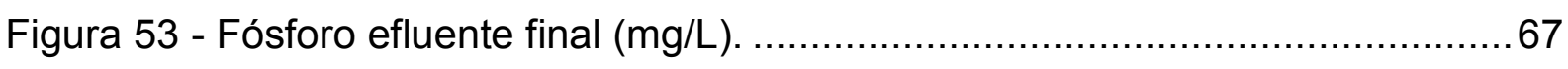

Figura 54 - Fósforo total: Eficiência de remoção total na ETE ABC (\%). ................67

Figura 55 - Série de valores: Fósforo total no esgoto afluente e efluente final da ETE

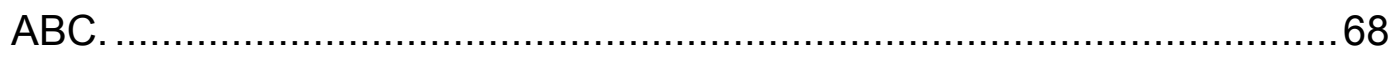

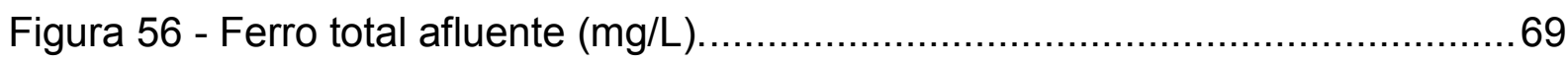

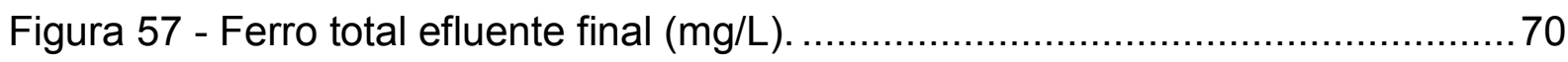

Figura 58 - Ferro total: Eficiência de remoção total na ETE ABC (\%).................... 70

Figura 59 - Série de valores: Ferro total no esgoto afluente e efluente final da ETE

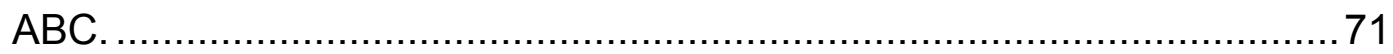

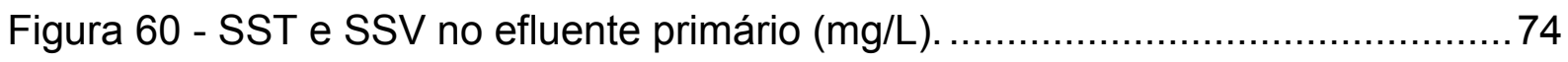

Figura 61 - SST e SSV: Eficiência de remoção nos decantadores primários (\%)....74

Figura 62 - Série de valores: SST e SSV no efluente primário............................ 75

Figura 63 - DBO e DQO no efluente primário $(\mathrm{mg} / \mathrm{L})$. ................................ 75

Figura 64 - DBO e DQO: Eficiência de remoção nos decantadores primários (\%)...76

Figura 65 - Série de valores: DBO e DQO no efluente primário da ETE ABC..........76

Figura 66 - Fósforo total: Eficiência de remoção no decantador primário (\%)..........77

Figura 67 - Série de valores: Fósforo total no efluente primário da ETE ABC..........77

Figura 68 - Ferro total: Eficiência de remoção no decantador primário (\%)............78

Figura 69 - Série de valores: Ferro total no efluente primário. ..........................78

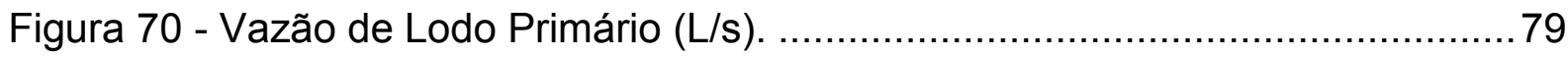




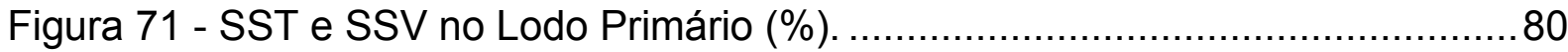

Figura 72 - SST e SSV no Lodo Adensado nos Adensadores por Gravidade (\%)....81

Figura 73 - Vazão de Lodo Adensado nos adensadores por gravidade (L/s). .......... 82

Figura 74 - SST e SSV nos Tanques de Aeração (mg/L)...................................... 85

Figura 75 - Índice Volumétrico do Lodo nos Tanques de Aeração $(\mathrm{mL} / \mathrm{g})$............... 85

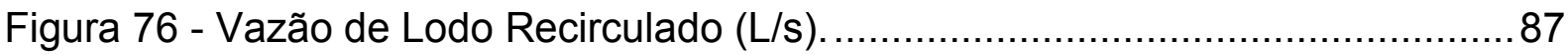

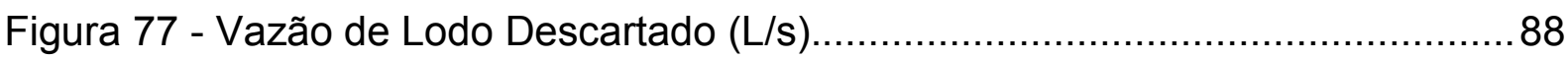

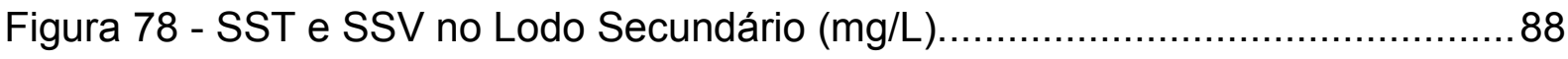

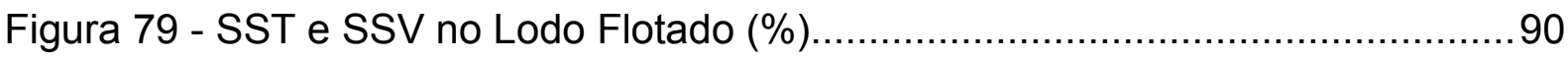

Figura 80 - Vazão de Lodo Flotado (L/s) ......................................................

Figura 81 - Vazão de lodo afluente e efluente dos Digestores (L/s) .......................92

Figura 82 - Tempo de detenção nos Digestores (dias). .........................................93

Figura 83 - Produção de Gás nos Digestores (m³/dia) .........................................93

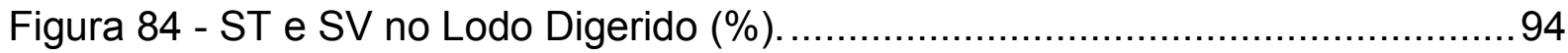

Figura 85 - Eficiência de remoção de SV nos Digestores da ETE ABC....................94

Figura 86 - Relação entre geração de gás e remoção de SV nos Digestores da ETE

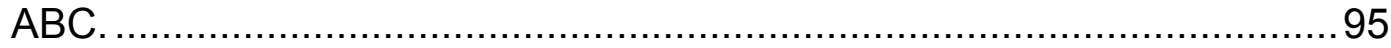

Figura 87 - Consumo de $\mathrm{CaO}$ no condicionamento do lodo (kg/dia) ......................97

Figura 88 - Consumo de $\mathrm{FeCl} 3$ no condicionamento do lodo (kg/dia).....................98

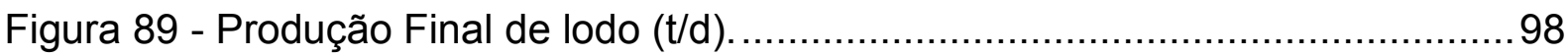

Figura 90 - Teor de Sólidos no lodo desidratado final da ETE ABC (\%). .................99 


\section{LISTA DE TABELAS}

Tabela 1 - Quantitativo de lodos gerados calculados pela fórmula da WRC para as ETA's da RMSP nos anos de 2003 e 2005

Tabela 2 - Frequência de amostragem no monitoramento da ETE ABC. 44

Tabela 3 - Produção média diária por mês de lodo na ETA Rio Grande durante o período de estudo

Tabela 4 - Comparação entre estimativas de produção de lodo pela formulação WRC e formulação estequiométrica.

Tabela 5 - Concentração adicional de SST no esgoto bruto da ETE ABC, decorrente do lançamento do lodo da ETA Rio Grande.

Tabela 6 - Variáveis monitoradas no esgoto bruto afluente e efluente final da ETE $A B C$ - período controle.

Tabela 7 - Variáveis monitoradas no esgoto bruto afluente e efluente final da ETE ABC - período pós-lançamento do lodo da ETA na ETE.

Tabela 8 - Valores de TAS dos decantadores primários da ETE ABC, para vazão média.

Tabela 9 - Variáveis monitoradas no efluente primário da ETE ABC - períodos controle e com lodo.

Tabela 10 - Variáveis monitoradas no lodo primário da ETE ABC - períodos controle e com lodo.

Tabela 11 - Parâmetros operacionais monitorados nos Adensadores por Gravidade períodos controle e com lodo.

Tabela 12 - Variáveis e Parâmetros Operacionais monitorados nos Tanques de Aeração - períodos controle e com lodo.

Tabela 13 - Parâmetros Operacionais monitorados nos Decantadores Secundários períodos controle e com lodo.

Tabela 14 - Variáveis monitoradas no Lodo Secundário - períodos controle e com lodo 
Tabela 15 - Variáveis e Parâmetros Operacionais monitorados nos Flotadores períodos controle e com lodo. 90

Tabela 16 - Variáveis e Parâmetros Operacionais dos Digestores - períodos controle

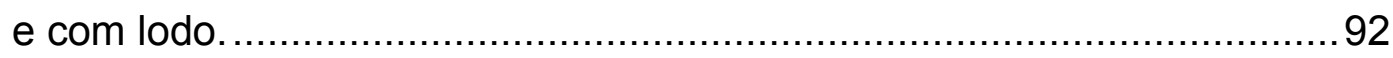

Tabela 17 - Variáveis e Parâmetros Operacionais monitorados no Condicionamento e na Desidratação do lodo na ETE ABC - períodos controle e com lodo. 97

Tabela 18 - Resumo das Análises Estatísticas. ...................................................100

Tabela 19 - Dados Mensais da Fase Líquida.................................................. 122

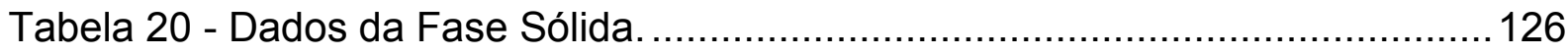

Tabela 21 - Parâmetros Operacionais ..............................................................128 


\section{SUMÁRIO}

1. INTRODUÇÃO

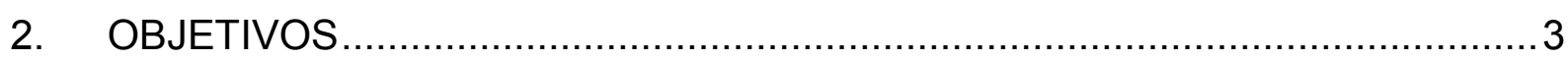

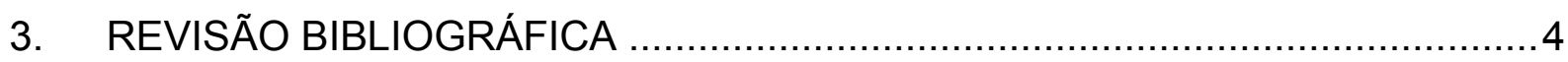

3.1. Estações de tratamento de água e a geração de resíduos.............................. 4

3.2. Estação de tratamento de esgotos sanitários, geração de resíduos e tratamento da fase sólida....................................................................... 10

3.3. Lançamento de lodos de ETA em ETE com processo de tratamento biológico

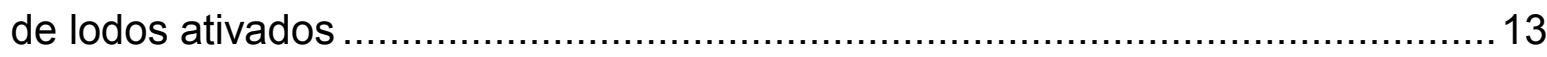

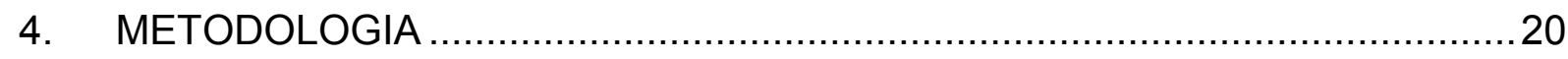

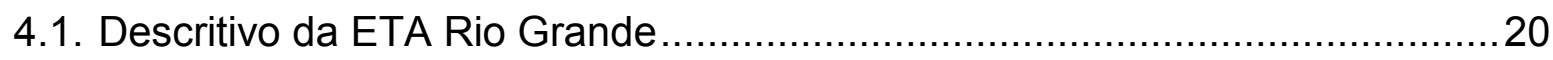

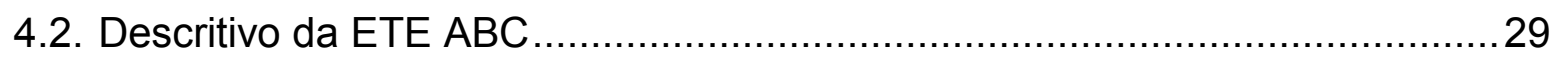

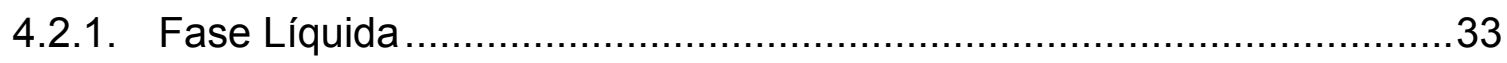

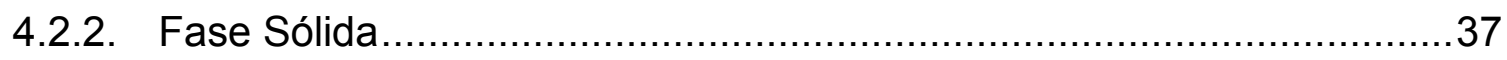

4.3. Descrição do histórico do lançamento de lodo da ETA na ETE......................41

4.4. Dados utilizados e métodos de análise ................................................... 42

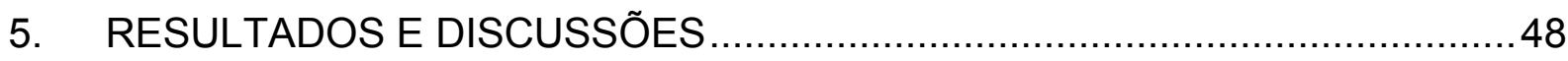

5.1. Lodo produzido na ETA Rio Grande ....................................................... 48

5.2. Esgoto afluente à $E T E A B C$ e eficiência global do tratamento .......................52

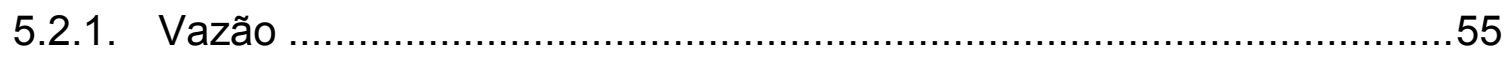

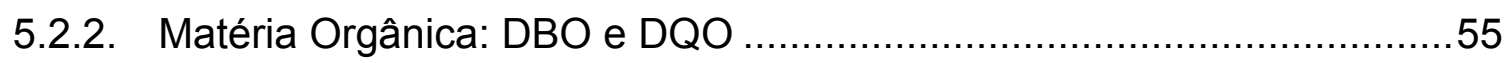

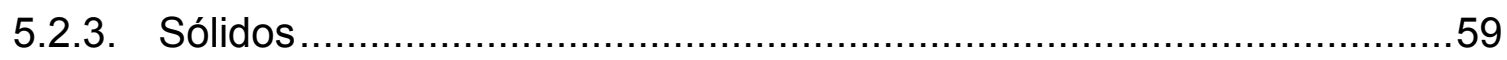

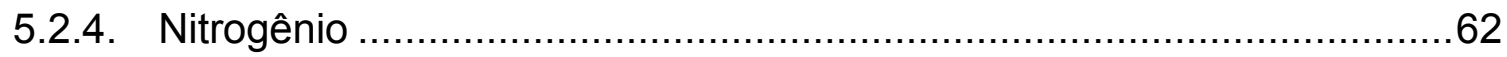

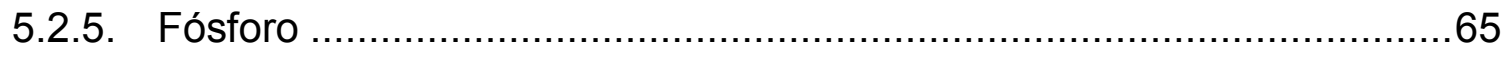

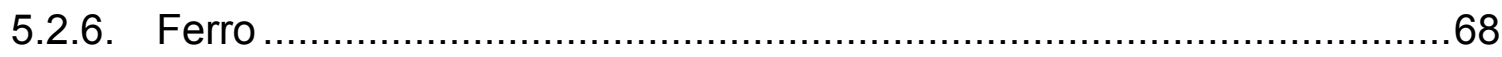

5.3. Impactos nas unidades de tratamento de fase líquida e sólida .....................71 


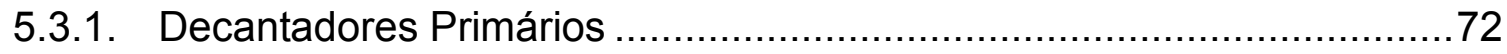

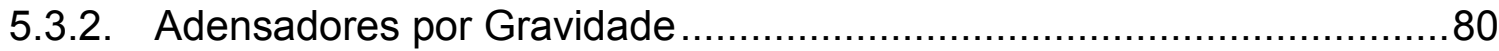

5.3.3. Tanque de Aeração e Decantador Secundário......................................82

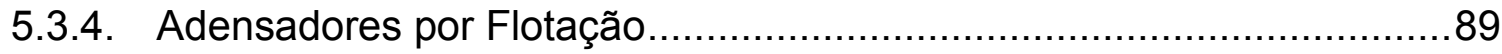

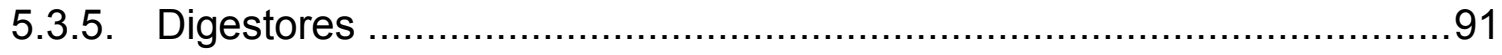

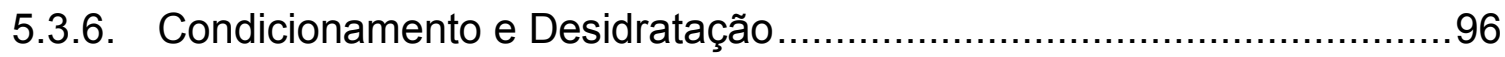

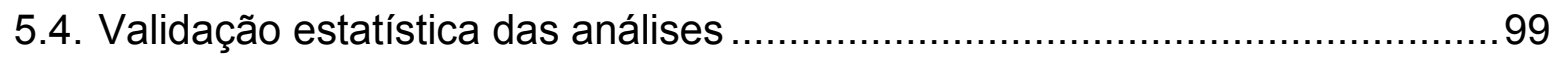

6. CONCLUSÕES E RECOMENDAÇÕES ………….................................110

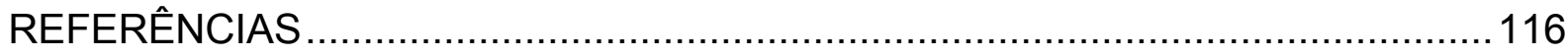

ANEXO A - DADOS UTILIZADOS - FASE LÍQUIDA …..................................121

ANEXO B - DADOS UTILIZADOS - FASE SÓLIDA …........................................125

ANEXO C - DADOS UTILIZADOS - PARÂMETROS OPERACIONAIS ................127

ANEXO D - ESTUDO ESTATÍSTICO - CEA / IME-USP ...................................129 


\section{INTRODUÇÃO}

O tratamento de águas para abastecimento público, por se tratar de um processo que visa à separação e retirada de impurezas das mesmas, gera certos resíduos. A quantidade de lodo gerada no processo de tratamento depende de diversos fatores, dentre eles a qualidade da água bruta, da qualidade e da dosagem do coagulante empregado, dos métodos de limpeza e lavagem, da automação do processo, etc. (DI BERNARDO, 2005).

Segundo a norma NBR 10.004, os lodos gerados em estações de tratamento de água (ETA) e de efluentes (ETE) são considerados resíduos sólidos, mesmo sendo composto por mais de $95 \%$ de água (ABNT, 1987). Sendo assim, por razões técnicas e ambientais, tais resíduos devem ser adequadamente tratados antes de serem dispostos no meio ambiente.

Há diversas formas de tratar o lodo produzido em uma ETA, sendo os métodos mais usados o condicionamento seguido de adensamento e desaguamento, por meio de centrífugas, filtros-prensa, lagoas de secagem, etc. Tal tratamento pode ser realizado nas dependências da ETA ou fora dela.

Uma prática que está em evidência é a disposição do lodo de ETA nas estações de tratamento de esgotos (ETE), uma vez que é uma alternativa que dispensa a implantação da linha de tratamento do lodo na ETA, cujo custo pode variar de $20 \%$ a $60 \%$ dos custos operacionais (ANDREOLI, 2001).

Deve-se levar em consideração que as ETA geralmente não têm a infraestrutura, nem espaço necessário para a instalação da mesma, para o tratamento dos lodos nelas gerados. Enquanto isso, nas ETE essa presença geralmente é garantida, uma vez que no processo de tratamento de esgotos por métodos biológicos, geram-se grandes quantidades de lodos, além de haver uma tradição em operação do lodo nestas estações (JANUÁRIO, 2005).

De modo a embasar tecnicamente tal prática, muitas pesquisas vêm sendo feitas nessa área, buscando avaliar os efeitos do lançamento dos lodos de ETA em ETE, nas mais diversas configurações de tratamento. $O$ tratamento convencional em ETA, como a própria definição indica, e processo de tratamento por lodos ativados em 
ETE são os mais comuns, de modo que é necessário se estudar o efeito desse tipo de combinação de tratamentos no tocante disposição de lodos, principalmente quando apresentam algum tipo de particularidade.

Desta forma, neste trabalho, foi escolhido para estudo o caso da ETE ABC, estação operada pela Sabesp e localizada na Região Metropolitana de São Paulo, a qual recebe desde janeiro de 2007 o lodo da ETA Rio Grande, também localizada na mesma região. Esta escolha foi feita por se tratar de um caso peculiar, devido ao fato da ETE operar com folga em sua capacidade, contando com infraestrutura para tratar o dobro da vazão que hoje recebe. 


\section{OBJETIVOS}

O objetivo desta dissertação é estudar os impactos causados nos processos da Estação de Tratamento de Esgotos do ABC decorrentes do lançamento de lodos gerados na Estação de Tratamento de Água Rio Grande, ambas localizadas na RMSP e operadas pela Sabesp.

Serão analisados os efeitos da introdução do lodo da ETA sobre os seguintes aspectos relativos ao processo de lodos ativados:

- Remoção de sólidos nos decantadores primários e secundários;

- Remoção de matéria orgânica nos decantadores e no reator biológico (tanque de aeração);

- Ocorrência do processo de nitrificação;

- Remoção de fósforo;

- Produção e qualidade do lodo da ETE; e

- Eficiência das demais etapas de tratamento da fase sólida: adensamento, digestão, condicionamento e desaguamento. 


\section{REVISÃO BIBLIOGRÁFICA}

\subsection{Estações de tratamento de água e a geração de resíduos}

Estações de tratamento de água (ETA) empregam diversos processos de tratamento, os quais dependem de fatores como as características da água bruta e os padrões de qualidade a serem atingidos. Do mesmo modo, os resíduos produzidos durante o tratamento de águas para abastecimento dependerão do processo utilizado. Dentre estas diversas concepções, podem-se citar como as mais utilizadas (AWWA, 1996):

- Tratamento por coagulação e filtração: o dito tratamento convencional, que visa à remoção de turbidez, e logo, de sólidos suspensos, e de organismos patogênicos. Tem-se em sequência as operações unitárias de coagulação (mistura rápida), floculação (mistura lenta), sedimentação (ou decantação) e desinfecção;

- Abrandamento por precipitação, que visa diminuir a dureza da água, complementando o tratamento convencional com uma etapa de abrandamento com cal;

- Tratamento com membranas de micro, ultra e nanofiltração, de osmose reversa e de eletrodiálise: neste caso o objetivo é remover turbidez, dureza, nitratos, radionuclídeos e alguns sólidos dissolvidos nas águas, podendo se estender à remoção de microrganismos patogênicos;

- Troca iônica: utilizando-se de resinas especiais, visa remover constituintes inorgânicos, incluindo dureza, nitratos, radionuclídeos e até arsênico;

- Adsorção em carvão ativado granular (CAG): o CAG é utilizado em diversos processos para a remoção de compostos orgânicos naturais e sintéticos das águas para abastecimento.

No denominado processo convencional, tem-se que os resíduos comumente gerados provêm de (DI BERNARDO, 2005): 
- Limpezas ou descargas dos decantadores (ou eventualmente em flotadores), responsável pela maior parcela mássica dos resíduos produzidos, chamados de lodo;

- Lavagem dos filtros, sendo este resíduo produzido em maior quantidade volumétrica; e

- Lavagem de tanques de preparação de suspensões e soluções de produtos químicos.

Segundo AWWA (1996), podem-se dividir os resíduos gerados em ETA em quatro categorias:

- Lodos, isto é, água contendo altas concentrações de sólidos suspensos, advindos da água bruta e dos produtos químicos utilizados no processo de tratamento, principalmente coagulantes;

- Águas de lavagem de filtros, geradas no processo de retrolavagem destas unidades, as quais contém todo o material retido no meio filtrante;

- Concentrados (salmoura) resultantes do processo de troca iônica e no tratamento por membranas;

- Material sólido e de preenchimento, como resinas de troca iônica, CAG e meio filtrante gastos;

- Emissões gasosas, produzidas, por exemplo, em instalações de stripping e de controle de odor.

A Figura 1 abaixo apresenta os pontos geradores de resíduos em uma ETA convencional (podendo o sulfato de alumínio ser substituído por outros coagulantes):

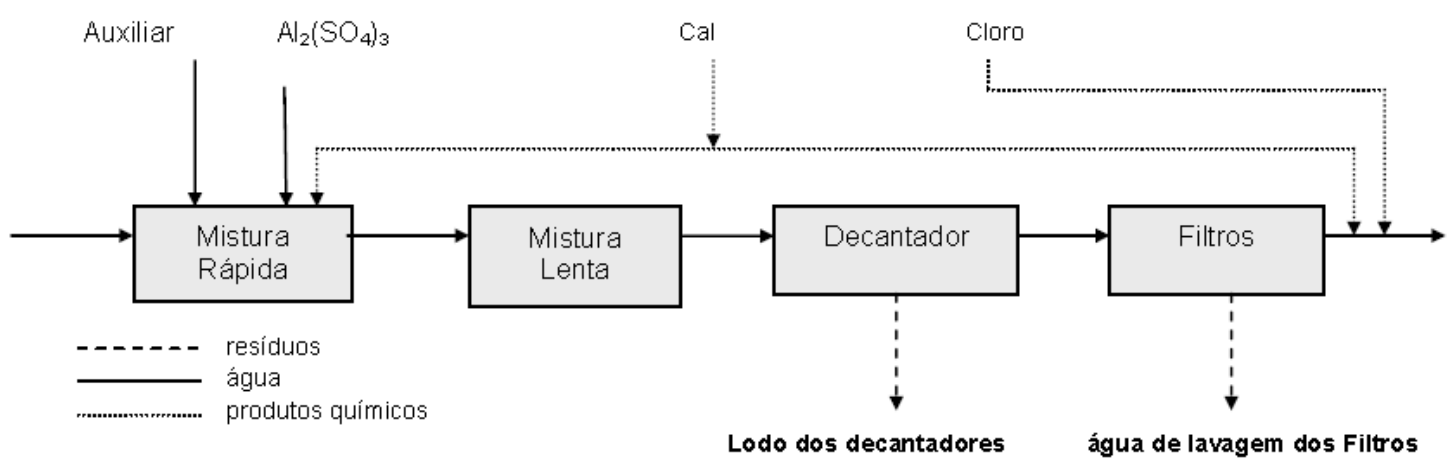

Figura 1 - Resíduos produzidos em ETA do tipo convencional. (Fonte: Cordeiro, 1999). 
Os lodos são resíduos semissólidos produzidos em processos de remoção de sólidos suspensos na água, sendo o mais significativo destes a sedimentação. Os tipos mais comuns de lodo gerados são os lodos de coagulantes e coadjuvantes de coagulação (polímeros), de abrandamento químico, e ferro e manganês oxidados. São compostos, principalmente, por hidróxidos sólidos gelatinosos, como $\mathrm{Al}(\mathrm{OH})_{3}$, $\mathrm{Fe}(\mathrm{OH})_{3}$ e $\mathrm{Mn}(\mathrm{OH})_{2}$ (AWWA, 1996).

As vazões de lodo e concentrações de sólidos em suspensão nos mesmos dependem de fatores como a qualidade da água bruta, a pureza dos produtos químicos empregados no tratamento, o tipo de sal utilizado como coagulante, e a maneira como os sólidos gerados são removidos do decantador. Diversas equações podem ser utilizadas para prever a quantidade de lodo gerado quando da utilização de coagulantes de sais de ferro e de alumínio. São equações empíricas que levam em conta a qualidade da água bruta e a quantidade de produtos químicos utilizada (coagulante e coadjuvantes), como apresentado por Cornwell et al. (1987):

$S=(8,34 \cdot Q) \cdot(0,44 \cdot A l+S S+A)$

onde,

$\mathrm{S}=$ produção de lodo (em Ib/dia);

$\mathrm{Q}=$ vazão em processo, em milhões de galões por dia (mgd);

$\mathrm{Al}=$ dosagem de sal de alumínio (mg/L, considerando $17,1 \%$ de $\left.\mathrm{Al}_{2} \mathrm{O}_{3}\right)$;

SS = sólidos em suspensão total da água bruta (mg/L);

$A=$ geração de sólidos pela adição de outros produtos químicos auxiliares, como polímero ou PAC (mg/L).

No caso do ferro, tem-se:

$S=(8,34 \cdot Q) \cdot(2,9 \cdot F e+S S+A)$ 
onde,

$\mathrm{Fe}=$ dosagem de sal de ferro (mg Fe/L);

Em Saron e Leite (2001) é apresentada uma equação do Water Research Center (WRC):

$P=(1,2 \cdot T+0,07 \cdot C+k \cdot D+A)$

onde, $\mathrm{P}$ representa a produção de sólidos ( $\mathrm{g}$ matéria seca $/ \mathrm{m}^{3}$ de água tratada), T é a turbidez (UT), C a cor aparente da água bruta (uH), D a dosagem de coagulante (mg/L), k o coeficiente de precipitação (igual a 0,26 quando se usa sulfato de alumínio liquido; 0,66 no caso do cloreto férrico anidro; e 0,81 para o sulfato férrico), e A a dosagem de outros produtos químicos, como polímeros e CAP (mg/L).

Na Tabela 1 abaixo são apresentadas as estimativas de produção de lodo nas ETA da RMSP, calculadas através da fórmula da WRC (ENCIBRA e HIDROCONSULT, 2004 apud JANUÁRIO e FERREIRA FILHO, 2007). Percebe-se uma grande variação na quantidade de lodo gerado nas ETA, reforçando o fato de que tal produção não depende apenas da vazão de água tratada, mas de outros fatores como a qualidade da água bruta, dos produtos químicos utilizados e da época do ano (em períodos chuvosos, há maior turbidez e concentração de SST na água):

Tabela 1 - Quantitativo de lodos gerados calculados pela fórmula da WRC para as ETA da RMSP nos anos de 2003 e 2005

\begin{tabular}{cccccc}
\hline ETA & $\begin{array}{c}\text { Vazão } \\
\text { média } \\
\mathbf{2 0 0 3}\left(\mathbf{m}^{3} / \mathbf{s}\right)\end{array}$ & $\begin{array}{c}\text { Vazão } \\
\mathbf{m e ́ d i a} \\
\mathbf{2 0 2 5}\left(\mathbf{m}^{3} / \mathbf{s}\right)\end{array}$ & $\begin{array}{c}\text { Lodo gerado } \\
\left(\mathbf{g} / \mathbf{m}^{3} \text { água) }\right.\end{array}$ & $\begin{array}{c}\text { Produção de } \\
\text { lodo 2003 } \\
\text { (base seca - } \\
\text { t/dia) }\end{array}$ & $\begin{array}{c}\text { Produção de } \\
\text { lodo 2025 } \\
\text { (base seca - } \\
\text { t/dia) }\end{array}$ \\
\hline Guaraú & 31,3 & 33,0 & 9,7 & 26,3 & 27,7 \\
ABV & 13,5 & 16,0 & 34,7 & 40,5 & 48,0 \\
Taiaçupeba & 9,6 & 18,0 & 21,8 & 18,2 & 33,9 \\
Rio Grande & 4,7 & 7,0 & 22,8 & 9,3 & 13,8 \\
Casa Grande & 3,9 & 4,0 & 13,1 & 4,4 & 4,5 \\
Morro Grande & 1,0 & 1,2 & 32,0 & 2,8 & 3,3 \\
Baixo Cotia & 0,9 & 1,0 & 59,7 & 4,6 & 5,2 \\
TOTAL & 64,9 & 80,2 & - & 106,1 & 136,4 \\
\hline
\end{tabular}

Outras equações empíricas podem ser encontradas em AWWA (1978) e Ferreira Filho e Alem Sobrinho (1998). É importante dizer que tais equações devem ser 
utilizadas principalmente na fase de projeto da ETA, e estando esta operante, devese quantificar a quantidade de lodo através do monitoramento de sua produção ao longo do ano.

Em relação à geração de água de lavagem, esta representa um volume de 2 a $5 \%$ do total processado na ETA. A concentração de sólidos suspensos presente nestas águas varia ao longo do processo de retrolavagem, indo de altas para baixas concentrações, numa faixa de 50 a $400 \mathrm{mg} / \mathrm{L}$. É prática comum o retorno destas águas de lavagem para o início do processo de tratamento na ETA, havendo uma equalização prévia para que o retorno não represente mais de $10 \%$ da vazão em processo na estação (AWWA, 1996).

Para uma caracterização completa do lodo de ETA, faz-se necessário conhecer os seguintes parâmetros físico-químicos: série de sólidos (totais, voláteis, em suspensão total e suspensos voláteis), granulometria, densidade, resistência específica, pH, DBO (demanda bioquímica de oxigênio), DQO (demanda química de oxigênio), concentração dos principais íons metálicos de interesse (exemplo: alumínio, ferro, manganês, cádmio, cobre, cromo, chumbo, mercúrio, níquel, zinco, etc.), concentração de fósforo total, nitrogênio total, além de indicadores biológicos, como coliformes totais e fecais (SUNDEFELD JR., 2007).

As características físicas do lodo devem ser conhecidas, pois afetam diretamente a forma como tal material será transportado, adensado, desaguado e disposto, isto é, o processo de tratamento do lodo. Sendo assim, as características que devem ser analisadas com critério são: o teor de sólidos, a resistência especifica ao desaguamento, a compressibilidade (capacidade de deformação durante o desaguamento), tensão de cisalhamento, densidade (relacionada ao tamanho dos flocos, apresenta valores na faixa de 1,03 a $1,44 \mathrm{~g} / \mathrm{cm}^{3}$ ) e distribuição granulométrica das partículas.

As características químicas mais importantes do lodo são o teor de sólidos, a presença de metais - muitas vezes decorrente de impurezas presentes nos produtos químicos utilizados -, e a toxicidade. Tais características estão associadas à disposição final e às possibilidades de reuso benéfico do lodo (AWWA, 1996).

Vale dizer que o teor de sólidos é uma característica física e química, pois depende da qualidade da água bruta, do tipo e dosagem de coagulantes e de outros produtos 
químicos utilizados no processo de tratamento. Águas com alta turbidez tendem a gerar lodos com maior concentração de sólidos. A utilização de sais de alumínio como coagulantes resulta num menor teor de sólidos quando comparada ao uso de outros sais metálicos. Além disso, o pH da água durante o processo de coagulação também influencia a quantidade de sólidos presente no lodo, de acordo com o coagulante utilizado. A utilização de polímeros não afeta a concentração de sólidos no lodo, pois não interferem na presença de água dentro dos flocos, agindo apenas na superfície externa dos mesmos (AWWA, 1996).

Uma vez caracterizado, o lodo deve ser tratado, o que consiste em aumentar o teor de sólidos no mesmo, por adensamento ou desidratação, de modo a torná-lo menos liquido, facilitando assim seu manejo e transporte à disposição final.

Segundo Di Bernardo (2005), o tratamento do lodo gerado na ETA compreende os seguintes processos: coleta nos pontos geradores; equalização em tanques, quando necessário; condicionamento com produtos químicos (geralmente polímeros aliados a sulfato de cálcio hidratado), para desestabilizar as partículas e facilitar a liberação da água; adensamento do lodo, onde se aumenta o teor de sólidos no lodo (chegando a valores de massa especifica de 1,01 a 1,04 kg/L), sendo as tecnologias mais utilizadas o método por gravidade, por flotação com ar dissolvido ou por equipamentos mecânicos, como filtro de esteira, adensador de disco, de peneira, e tambor rotativo; e desaguamento, onde o teor de sólidos deve chegar a, pelo menos, 20\% (200 g/L de SST), sendo realizado em leitos de secagem, centrífugas ou filtros prensa, de forma a ocorrer uma diminuição significativa de volume de lodo que facilita o transporte para disposição final.

Em relação à disposição final destes resíduos, têm-se diversas formas e métodos, sendo o mais simples e inadequado o lançamento direto em corpos d'água. Outra maneira geralmente utilizada é a disposição em aterros sanitários. Além destes, têmse outros métodos, a saber (DI BERNARDO, 2005; JANUÁRIO e FERREIRA FILHO, 2007):

- Disposição em aterros de resíduos particulares, municipais ou exclusivos; 
- Disposição direta no solo, que pode gerar certos benefícios como ajuste de $\mathrm{pH}$ e aumento da capacidade de retenção de água, estabilização do solo e recuperação de áreas degradadas;

- Reciclagem, com a utilização na produção de cimento, por conter teores consideráveis de sílica, ferro e alumínio, ou na fabricação de tijolos e blocos cerâmicos, quando sua composição for prioritariamente de argila, silte e coagulantes;

- Outras formas, como tratamento via compostagem, no cultivo de grama, em mistura de solo comercial, na plantação de cítricos, no controle de $\mathrm{H}_{2} \mathrm{~S}$, incineração e recuperação de coagulantes.

Uma alternativa interessante de disposição do lodo de ETA, tanto do ponto de vista técnico quanto do ponto de vista econômico é o lançamento do lodo no sistema de coleta, afastamento e tratamento de esgotos, adaptado para tal, de modo que este resíduo atinja uma ETE, sendo nela tratado em suas instalações de tratamento de fase sólida.

\subsection{Estação de tratamento de esgotos sanitários, geração de resíduos e tratamento da fase sólida}

Entende-se como processo de tratamento biológico de esgotos sanitários via lodos ativados um sistema onde ocorre, após um tratamento primário que remove o material mais grosseiro do esgoto bruto (gradeamento, desarenação e decantação primária), a degradação da matéria orgânica contida no esgoto por meio da ação de microrganismos, suspensos em flocos na massa líquida, na presença de oxigênio, fornecido artificialmente. Podem ocorrer, além da remoção da matéria orgânica, os processos de nitrificação e remoção de fósforo.

Seguido do processo de aeração, tem-se uma unidade de separação de sólidos (decantador secundário), na qual parte destes retorna para o sistema de aeração, e parte é descartada do processo, constituindo assim outro ponto de geração de resíduos (o lodo) no tratamento de esgotos sanitários, além do tratamento primário já citado, que gera resíduos grosseiros, areia e lodo (este último no decantador primário). 
A massa biológica contida no reator do processo de lodo ativado é constituída de agregados de microrganismos, material coloidal orgânico e inorgânico, e material particulado onde todos estão unidos numa matriz orgânica compacta. Um grande número de protozoários está fixo aos flocos, os chamados pedunculados. Também se têm na massa líquida e dentro da matriz do floco ciliados livre-nadantes e flagelados (HORAN, 1990). Em sua maioria, se tratam de organismos heterotróficos.

O processo de lodos ativados tem como principais fatores influentes:

- pH: segundo Metcalf e Eddy (2003), o pH para a remoção de matéria orgânica deve ser mantido próximo ao neutro $(7,0)$, podendo variar entre 6 e 9; já para a nitrificação, deve se encontrar entre 7,5 e 8,5. A variação de $\mathrm{pH}$ na massa líquida depende da alcalinidade do afluente e da produzida e consumida no sistema;

- Temperatura: influencia a atividade microbiana, as taxas de transferência gasosas e as características de sedimentação dos sólidos biológicos (METCALF e EDDY, 2003);

- Toxicidade: os microrganismos são sensíveis a certas substâncias orgânicas e inorgânicas. Os compostos orgânicos incluem solventes orgânicos, aminas, proteínas, taninos, compostos fenólicos, alcoóis, cianetos, éteres, carbamatos e benzenos. Os organismos nitrificantes são mais sensíveis que microrganismos heterotróficos, sendo bons indicadores da presença de compostos orgânicos tóxicos a baixas concentrações (METCALF e EDDY, 2003);

- Presença de metais: pequenas concentrações de metais, como níquel, cromo e cobre, também são tóxicas aos microrganismos envolvidos no processo de lodos ativados;

- Presença de nutrientes: os principais nutrientes inorgânicos para os microrganismos são N, S, P, K, Mg, Ca, Fe, Na e Cl. Em estações de tratamento de esgotos municipais, geralmente, há quantidades de nutrientes suficientes, mas em águas residuárias industriais pode ser necessária à adição nos processos biológicos de tratamento (METCALF e EDDY, 2003).

Para o funcionamento correto do processo de tratamento, é fundamental que a etapa de separação de sólidos ocorra de forma eficiente, condicionada por outros 
parâmetros de controle do processo, como concentração de OD e de nutrientes, e o $\mathrm{pH}$. Os problemas que podem ocorrer nessa fase do tratamento são o crescimento disperso de microrganismos (quando estes não conseguem se ligar uns aos outros), o intumescimento gelatinoso (produz um lodo viscoso, que sedimenta e compacta mau), flocos pontuais (quando estes são muito pequenos), intumescimento filamentoso (excesso de microrganismos filamentosos, gerando flocos de estrutura difusa, com pobres características de sedimentação) e formação de escuma (formação de flocos ligados às bolhas de ar e que flotam) (ASADA, 2007).

Em suma, o tratamento biológico de esgotos pelo processo de lodos ativados gera como resíduos (ANDREOLI et al., 2001):

- Material grosseiro, vindo do gradeamento;

- Areia, retirada nas unidades de desarenação do tratamento preliminar, sendo encaminhada para aterros sanitários, junto com o material gradeado;

- Lodo primário, saído dos decantadores primários;

- Lodo secundário, retirado nos decantadores secundários e em parte recirculado para os tanques de aeração.

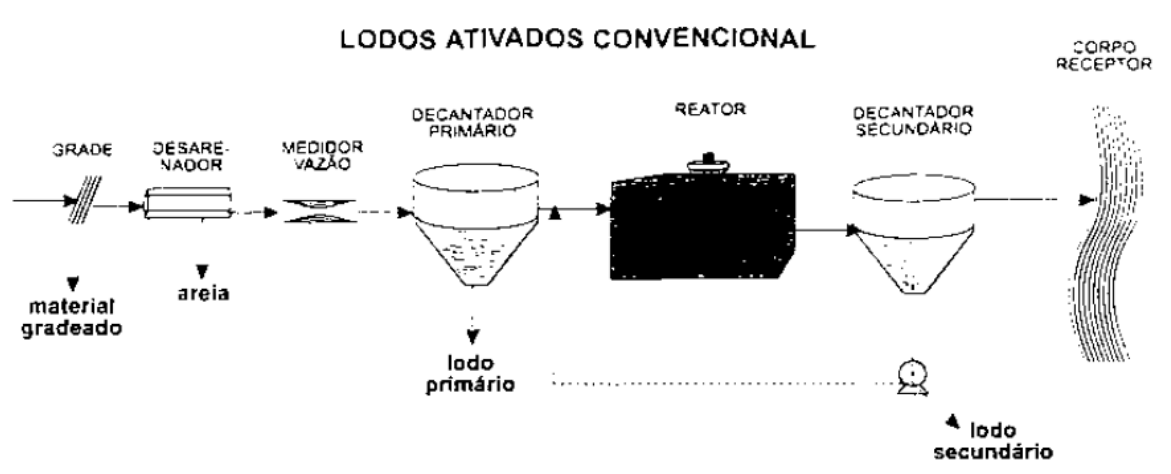

Figura 2 - Processo de lodos ativados e geração de resíduos. (Fonte: ANDREOLI et al., 2001).

Como a produção de lodo em uma ETE por lodos ativados é maior do que em uma ETA, uma vez que o tratamento biológico é fundamentado na existência de biomassa em suspensão na massa líquida, é comum que as estações de tratamento de esgotos contem com instalações de tratamento de fase sólida, o qual, 
semelhante ao tratamento de lodo de ETA, tem como principais objetivos (ANDREOLI et al, 2001):

- Adensamento, através da remoção de umidade, garantindo assim menor volume. Para o lodo primário, este é feito por gravidade, enquanto para o secundário, por flotação, sendo isso consequência do tipo de lodo gerado em cada decantador;

- Estabilização, ou seja, remoção de matéria orgânica (redução de sólidos voláteis), atenuando maus odores no tratamento e manuseio do lodo. Geralmente, faz-se uma digestão do lodo, que pode ser aeróbia ou anaeróbia;

- Condicionamento, preparando o lodo para a desidratação através da adição de produtos químicos, como coagulantes e polieletrólitos;

- Desaguamento/desidratação, onde se retira o máximo de umidade restante (e consequentemente volume), utilizando métodos naturais (leitos ou lagoas de secagem), mecânicos (centrífugas, filtros prensa, prensas desaguadoras) ou térmicos (secagem térmica), de modo a se ter menores custos com transporte e destinação final e facilitar o manuseio;

- Higienização, ou seja, remoção de organismos patogênicos, sendo necessária em caso de uso agrícola do lodo;

- Disposição final: destinação final dos subprodutos, mais comumente feita em aterros sanitários, ou dando usos alternativos ao lodo, como disposição agrícola. Antes da disposição final pode ocorrer algum tipo de transformação do lodo, como incineração e oxidação úmida.

\subsection{Lançamento de lodos de ETA em ETE com processo de tratamento biológico de lodos ativados}

Constituindo um método alternativo de disposição final de lodo de ETA, o lançamento destes em ETE vem sendo considerado uma proposta interessante, sob o ponto de vista técnico e econômico. 
O transporte de lodo de uma instalação para outra pode ser feito pelo lançamento do lodo da ETA por caminhão, ou por tubulação exclusiva, chamada de lododuto. No Brasil, o lançamento de lodo em rede coletora de esgoto doméstico é proibido por lei, sendo a resolução CONAMA no 430/11 (alteração e complementação da resolução CONAMA $n^{\circ}$ 357/05) válida em âmbito federal, e o decreto $n^{\circ}$ 8.468/76 (artigos 18 e 19) complementar a esta no estado de São Paulo (CONAMA, 2005; CONAMA, 2011; SÃO PAULO, 1976).

AWWA (1999) indica que a adição de lodo de ETA em instalações de tratamento de esgotos pode impactar significativamente a qualidade do efluente primário, o consumo de volume útil dos digestores e com isso a eficiência dos mesmos - uma vez que o lodo de ETA é prioritariamente inorgânico e não biodegradável -, e o potencial de aplicação do lodo biológico na agricultura ou compostagem, ao diminuir a concentração de nutrientes e poder aumentar a concentração de metais no biossólido.

Segundo Cornwell et al. (1987) a disposição dos resíduos de ETA em ETE pode ser amplamente praticado e ter sucesso se for realizado um constante monitoramento do sistema e uma equalização do lodo proveniente dos decantadores e dos filtros antes do descarte na ETE, a fim de se evitar cargas de choque. Os possíveis efeitos no tratamento biológico de esgotos, tanto benéficos como prejudiciais, estão relacionadas à toxicidade, remoção de sólidos suspensos ou aumento destes, remoção de DBO/DQO ou aumento destes e remoção de fósforo no efluente final.

Babatunde e Zhao (2007) concluem que a maior remoção de matéria orgânica e de fósforo nos decantadores primários após a adição de lodo de ETA ocorre pelos mecanismos de sedimentação por varredura e adsorção no floco.

Em AWWA (1996), realizou-se um levantamento de diversas ETA dos EUA que praticam o lançamento de lodo em ETE, destacando-se:

- A necessidade de equalizar as vazões afluentes de lodo, de modo a uniformizar a entrada deste na ETE, evitando assim sobrecargas;

- Deve-se atentar para a qualidade do lodo lançado, a fim de se evitar problemas com toxicidade, principalmente relacionada à presença de metais pesados, advindos tanto do manancial quanto de impurezas presentes nos produtos químicos utilizados no tratamento da água. 
Mesmo se o lodo contiver metais ditos essenciais, isto é, necessários para o desenvolvimento da microbiota do lodo ativado, caso a sua concentração seja muito alta, pode gerar efeitos adversos, inibitórios ao crescimento microbiano;

- Ao se promover o lançamento em tubulação por gravidade, deve-se atender a certas exigências hidráulicas, como uma velocidade mínima de $0,8 \mathrm{~m} / \mathrm{s}$, vazões de "flushing" para limpeza da linha. Se o lançamento se der por conduto forçado, levar em conta que o lodo possui características de fluido diferentes da água;

- A escolha do ponto de lançamento do lodo da ETA na ETE - se na linha de tratamento da fase líquida ou diretamente na da fase sólida - deve estar de acordo com a capacidade da ETE e as características expostas nos três itens acima;

- Deve-se levar em conta o adicional de carga hidráulica, geralmente atenuado no caso da chegada do lodo via rede coletora; de carga orgânica, que geralmente não significa um impacto significativo; da carga de sólidos, a qual pode gerar impactos nos decantadores e na qualidade do lodo final;

Em relação à remoção de matéria orgânica nos tanques de aeração, medida em DBO, DQO ou COT, os impactos observados não foram significativos, sendo apenas destacada a influência inibitória que a toxicidade do lodo de ETA pode causar no desenvolvimento dos microrganismos.

Como impacto na geração de lodos no tratamento de esgotos, tem-se uma maior geração volumétrica nos decantadores primários, com o lodo apresentando menor teor de sólidos, causando assim impactos nas instalações de tratamento de fase sólida - maior necessidade de adensamento e maior quantidade de lodo para desaguamento - e nas linhas de recirculação/retorno de lodo. Em alguns casos, observou-se sobrecarga nos decantadores secundários, levando ao carreamento de sólidos pelo efluente final, o qual mesmo assim ainda respeitou os limites de emissão da legislação vigente.

Se a carga de sólidos adicional advinda do lançamento de lodo da ETA não é significativamente alta em relação à já existente e há capacidade volumétrica suficiente, o processo de digestão anaeróbia do lodo não sofre impactos 
significativos. Neste processo, deve-se atentar para a relação entre sólidos voláteis e sólidos totais, que pode diminuir com a adição do lodo da ETA, o qual é majoritariamente inorgânico.

Já nas unidades de adensamento, foram observados alguns impactos negativos, como sobrecarga de sólidos e problemas de sedimentabilidade do lodo (IVL). Em compensação, nas instalações de desaguamento de lodo - centrífugas, filtrosprensa, leitos de secagem, etc. - foram observadas ou melhorias na capacidade de desaguamento, gerando tortas com maior teor de sólidos, ou a mera manutenção da eficiência observada antes do lançamento do lodo de ETA na ETE (AWWA, 1996).

Outros estudos indicam melhorias no desaguamento e sedimentabilidade, além da diminuição no consumo de produtos químicos no condicionamento do lodo na ETE, pelo fato de o coagulante presente no lodo da ETA garantir um esqueleto para 0 lodo biológico (BABATUNDE e ZHAO, 2007).

Carvalho (2000) realizou estudos para verificar as interferências do lançamento de resíduos de uma ETA, que utilizava cloreto férrico como coagulante, na decantação primária, digestão de lodo e no tratamento biológico do esgoto em uma ETE. Em termos gerais, os resultados indicaram como impactos significativos o aumento na eficiência de sedimentação, porém havendo maior volume de lodo primário, embora menos concentrado. Em relação à qualidade do efluente final, não foram verificadas interferências significativas, concluindo-se que resíduos similares aos gerados na ETA estudada poderão ser dispostos em ETE com decantação primária, sem interferências prejudiciais no seu desempenho.

Scalize (2003) também analisou os impactos da adição de lodo de ETA no tratamento de esgotos, lodo este proveniente da ETA São Carlos, do município paulista de mesmo nome, realizando ensaios em colunas de sedimentação com o efluente da ETE Araraquara. Tal ETA utiliza como coagulante o sulfato de alumínio. As variáveis SST, SSV, cor, turbidez, DQO, coliformes totais, Escherichia coli e parasitas, pesquisados no sobrenadante, diminuíram com o aumento da dosagem de resíduo da ETA adicionada. Porém, em relação ao lodo produzido (sedimentos obtidos nas colunas de sedimentação), encontrou-se maior quantidade de ST e menor resistência específica após a adição de lodo da ETA. 
Para analisar os efeitos sobre a digestão do lodo, realizaram-se testes de atividade metanogênica, os quais mostraram que a concentração molar de metano foi reduzida nos sistemas que receberam resíduo da ETA-SC, influenciando negativamente no desenvolvimento dos microrganismos metanogênica, devido à inibição.

Dando continuidade às análises, em uma segunda fase Scalize (2003) estudou os efeitos da adição do lodo da ETA Fonte em uma instalação piloto contendo efluente da ETE Araraquara, composta de lagoa de aeração seguida de lagoa de sedimentação. Neste caso, a ETA utiliza cloreto férrico como coagulante. Verificouse que o resíduo da ETA melhorou a qualidade do efluente em termos de DQO, DBO, SST, turbidez, cor, amônio, nitrato, NTK e fosfato total. Já o lodo formado apresentou-se em maior quantidade e com menor resistência específica, indicando um aumento da produção, porém com maior capacidade de desaguamento, comprovada pela menor quantidade de polieletrólito necessária para a desidratação em centrífuga. Baseado neste estudo não foi verificado interferências que possam impedir o lançamento do resíduo da ETA Fonte na ETE Araraquara (SCALIZE, 2003; SCALIZE e DI BERNARDO, 2009a e 2009b).

Estudos mais recentes apresentaram resultados satisfatórios em relação ao uso de lodo de ETA como agente coagulante e adsorvente para remoção de fósforo em ETE, alcançando-se remoções da ordem de 95\%. Tal remoção é justificada principalmente pela presença de íons ferro e alumínio na forma amorfa, e depende do $\mathrm{pH}$ do meio, sendo otimizada na região ácida. Tal característica adsorvente aponta para um uso eficiente de lodo de ETA em wetlands construídas, uma vez que uma das deficiências deste processo de tratamento é justamente a remoção de nutrientes (BABATUNDE e ZHAO, 2007; BABATUNDE et al, 2009; ZHAO et al, 2008).

Asada (2007) avaliou o efeito do lodo de ETA, aplicado em dosagens diversas, em uma instalação piloto operando segundo um sistema de lodos ativados com aeração prolongada. Neste estudo, notou-se que a adição de lodo de ETA no sistema não interfere na remoção de DBO, havendo manutenção da eficiência na ordem de $94 \%$, embora em termos de DQO a eficiência de remoção tenha diminuído com o aumento da dosagem de lodo da ETA. 
Além disso, no que se refere à sedimentabilidade do lodo biológico, percebeu-se uma melhora após a adição de lodo da ETA, devido à diminuição do IVL. Ainda em relação aos sólidos, foi observado um aumento na concentração de SS no tanque de aeração e na linha de retorno de lodo, além da produção de lodo, enquanto houve diminuição no valor da relação SSVISST, uma vez que o lodo de ETA é prioritariamente inorgânico (sólidos fixos). Em relação aos nutrientes, não foi observada alteração significativa nos processos de nitrificação e de remoção de fósforo (ASADA, 2007).

Alvarez Rosario (2007), por sua vez, estudou o efeito da disposição de lodo de ETA em sistema piloto de tratamento de esgotos por reator UASB. Neste estudo, chegouse a uma maior remoção de matéria orgânica, em termos de DQO e DBO, no reator que recebeu dosagens de lodo de ETA, atingindo eficiências da ordem de $70 \%$ a $78 \%$, contra a faixa de $64 \%$ a $70 \%$ do reator sem adição de lodo. Aumentou-se a produção de lodo, com diminuição da relação SSVISST conforme se aumentava a dosagem de lodo de ETA $(0,79$ a 0,74$)$. Em relação à remoção de fósforo, não foi observada alterações significativas na eficiência deste processo.

Sundefeld (2007) analisou os efeitos do recebimento de lodo de ETA em uma ETE real, no município de Juquitiba, a qual opera com dois reatores SBR - sequencial batch reactor - utilizando o processo de lodos ativados com aeração prolongada. Foram observados aumentos na concentração de sólidos no lodo (da ordem de $2.850 \mathrm{mg} / \mathrm{L}$ para $3.400 \mathrm{mg} / \mathrm{L})$, na produção de lodo de excesso $(40 \%)$, no valor de sólidos suspensos no efluente final $(73 \%)$ e na eficiência de remoção de fósforo. Por outro lado, observou-se uma diminuição na eficiência de remoção de matéria orgânica e de nitrogênio.

Um estudo em escala real foi realizado por Bueno et. al (2007), onde foram feitos testes na ETE do município paulista de Franca, a qual recebe o lodo proveniente da ETA Norte. Tal lodo é enviado à ETE através da rede de coleta doméstica, em períodos de menor vazão (madrugada), chegando a um decantador primário inativo da ETE, o qual funciona como tanque-pulmão para regularização das vazões, de modo que a aplicação do lodo na linha de tratamento da ETE foi feita em dosagens de 50 e $100 \mathrm{mg} \mathrm{ST/L}$. 
Como principais efeitos decorrentes da adição de lodo de ETA na linha de tratamento da ETE, observou-se:

- Melhora na eficiência dos decantadores, primário e secundário, com aumento da concentração de sólidos no lodo e queda da turbidez do efluente final, respectivamente;

- Mudança da coloração do lodo biológico de marrom para avermelhada (consequente aumento da cor) e redução no percentual de SSV em relação ao SST nos tanques de aeração;

- Redução da produção total de biogás nos biodigestores anaeróbios, causada não por efeito tóxico, mas apenas inibitório sobre os microrganismos metanogênicos responsáveis pela digestão anaeróbia do lodo;

- Houve aumento na remoção de fósforo, devido a maior precipitação deste nos decantadores primários. Porém, tais efeitos não chegam a alterar a qualidade do efluente final tratado no tocante a este parâmetro, o mesmo valendo para $\mathrm{DBO}_{5,20}$.

Sendo assim, constatou-se que o recebimento de lodo da ETA na ETE, nas condições testadas, interfere no desempenho operacional da ETE, mas que é possível conviver com os efeitos produzidos realizando algumas mudanças operacionais e eventuais aumentos de custos de operação/manutenção da ETE Franca (BUENO et al, 2007).

Os estudos acima apresentados obtiveram como conclusão mais importante que a adição de lodo de ETA em ETE não impacta significativamente o tratamento de esgoto, em diversas configurações de estações, mesmo ocorrendo diminuição na eficiência de alguns processos de remoção. Porém, ressalta-se que as ETE devem estar devidamente preparadas no que se refere às instalações de tratamento de fase sólida, pois é evidente que a produção de lodo aumenta no decorrer do processo de tratamento da fase líquida. Desta forma, de modo a complementar tais estudos, fazse necessário analisar também tais instalações de tratamento de fase sólida, se possível em ETE reais. 


\section{METODOLOGIA}

Neste capítulo primeiramente serão descritas as duas estações de tratamento analisadas neste trabalho: no caso da ETA Rio Grande, que realiza tratamento convencional de águas para abastecimento, serão descritas as características gerais do processo, os pontos geradores de resíduos e as características do lodo enviado à $E T E A B C$, da qual serão apresentados as características gerais do processo de tratamento da fase líquida e da fase sólida, e um histórico do recebimento de efluentes não domésticos (lodo e chorume).

As informações acima descritas foram obtidas do Memorial Descritivo da ETE ABC (SABESP, 2005a), e dos Relatórios Gerenciais da ETE (SABESP, 2005b, 2006, $2007,2008)$. Já os dados da ETA Rio Grande foram obtidos de um estudo técnico sobre a mesma (FERREIRA FILHO, 2006) e também diretamente com a equipe de operação.

A seguir, serão apresentados os dados a serem utilizados: pontos e frequências de amostragem, variáveis amostradas, dados gerenciais e períodos analisados.

Em relação às análises feitas neste trabalho, serão descritas a organização das estatísticas básicas, as formas de apresentação e de comparação e a obtenção dos resultados.

\subsection{Descritivo da ETA Rio Grande}

A ETA Rio Grande está localizada no município de São Bernardo do Campo, na RMSP, próxima da rodovia Anchieta ( $k m$ 26,5), e opera desde 1958. É responsável pelo tratamento da água do sistema Rio Grande, com captação neste braço da represa Billings, que foi isolado da mesma na década de 80 para garantir a qualidade das águas captadas.

O manancial apresenta problemas frequentes qualidade da água bruta, decorrentes da eutrofização - crescimento de algas e problemas de gosto e odor - e da estratificação sazonal - aumento na concentração de ferro e manganês. 


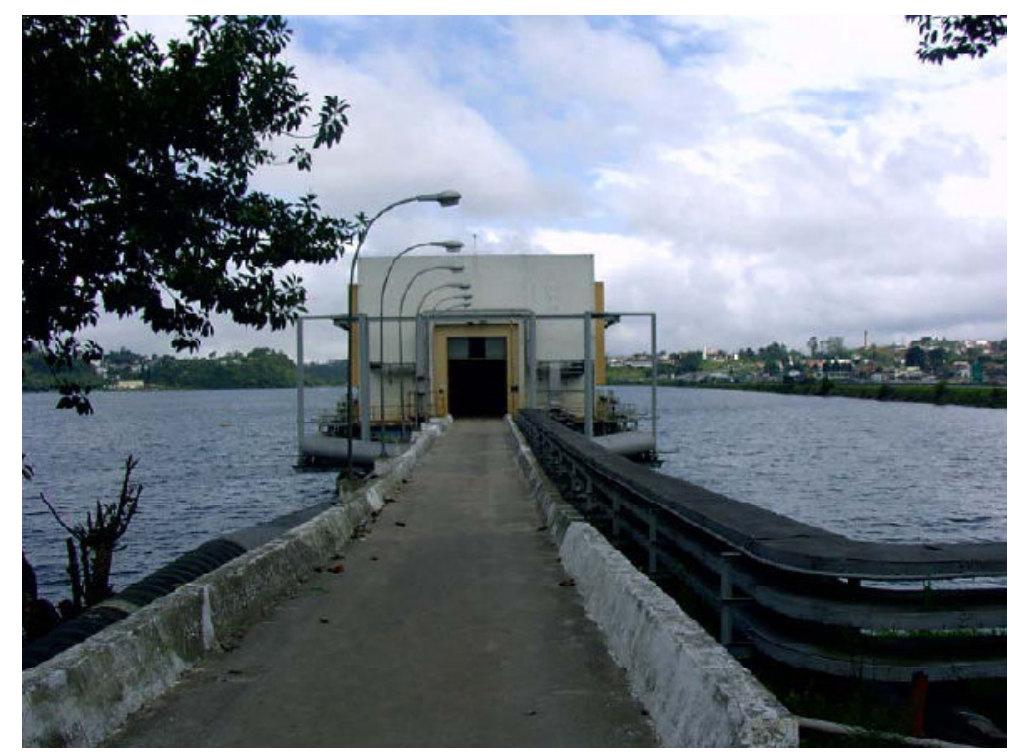

Figura 3 - Captação de água bruta da ETA Rio Grande.

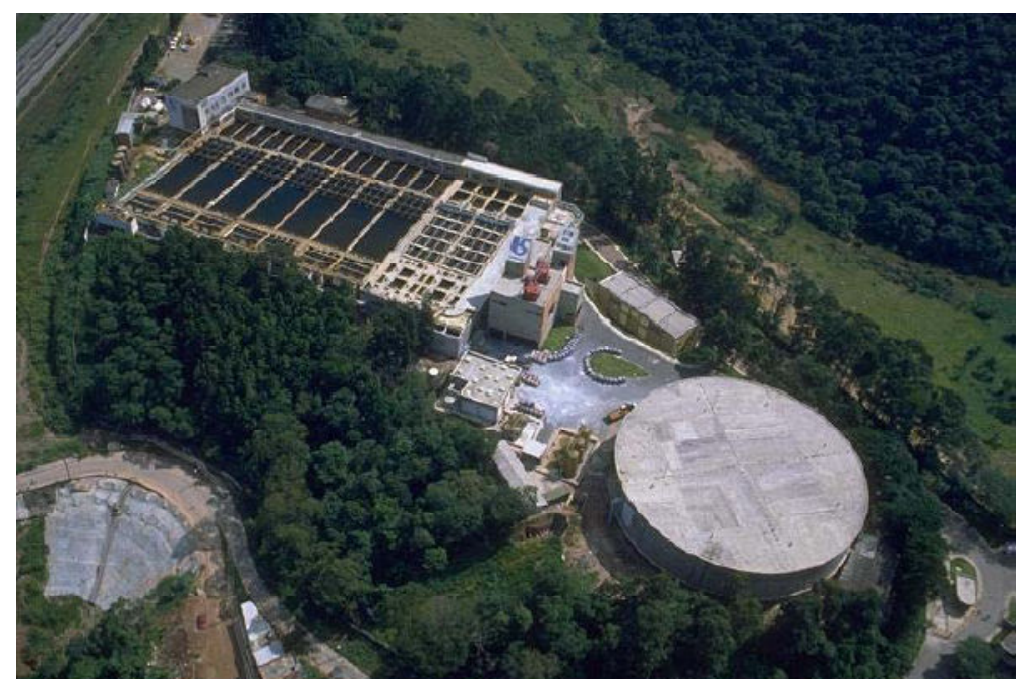

Figura 4 - Vista aérea da ETA Rio Grande.

Atualmente, a produção mensal do sistema Rio Grande situa-se na faixa de 11,7 milhões de $\mathrm{m}^{3}$, com vazão média de $4,50 \mathrm{~m}^{3} / \mathrm{s}$, sendo responsável por cerca de $6,5 \%$ da produção de água tratada na RMSP, abastecendo uma população de 1,2 milhões de habitantes, dos municípios de São Bernardo do Campo, Diadema e Santo André (Setor Paraíso).

Na Figura 5 abaixo, tem-se um fluxograma esquemático da ETA Rio Grande: 


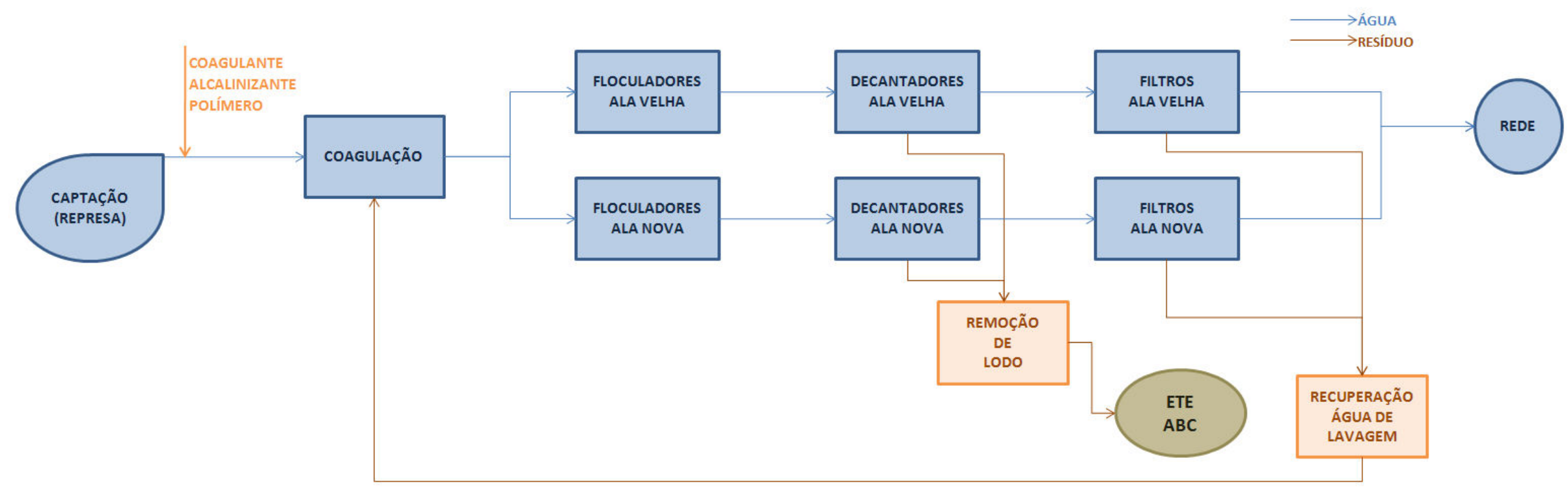

Figura 5 - Fluxograma esquemático da ETA Rio Grande 
A chegada de água bruta ocorre em uma caixa vertedoura contendo dois vertedores tipo bico de pato, onde ocorre a fase de mistura rápida, com a aplicação de sulfato férrico como coagulante e de cal para pré-alcalinização, quando necessária (em épocas que se necessita remover manganês, o que ocorre melhor em pH básico).

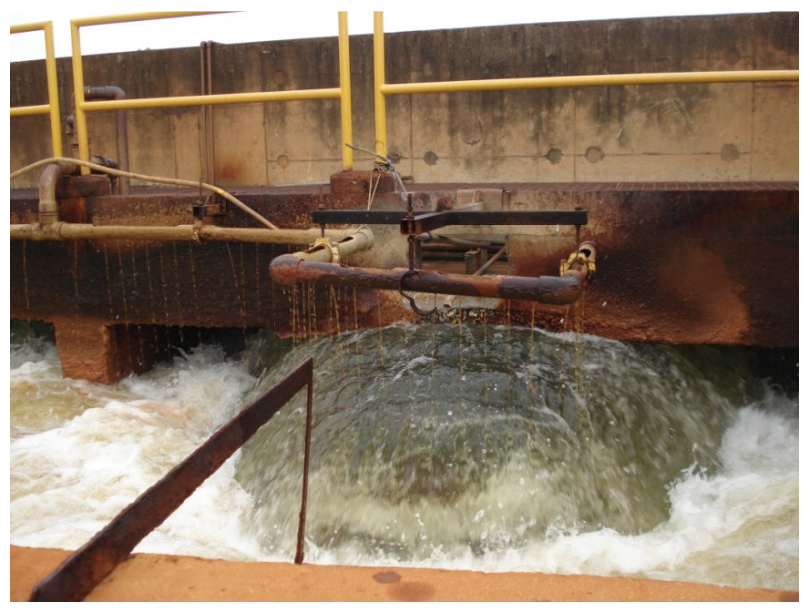

Figura 6 - Chegada da água bruta na ETA, com aplicação de produtos químicos.

O arranjo atual do módulo de tratamento apresenta duas concepções distintas, fruto das ampliações e modificações que a ETA sofreu ao longo dos anos, visando aumentar sua capacidade de produção. Há uma ala de tratamento denominada "antiga", composta de:

- Três floculadores hidráulicos de fluxo horizontal, cada um com 5 células, dimensões $11,4 \mathrm{~m} \times 10,2 \mathrm{~m} \times 3,57 \mathrm{~m}$, que garante, para uma vazão média de $5,0 \mathrm{~m}^{3} / \mathrm{s}$, um tempo de detenção em torno de 12 minutos;

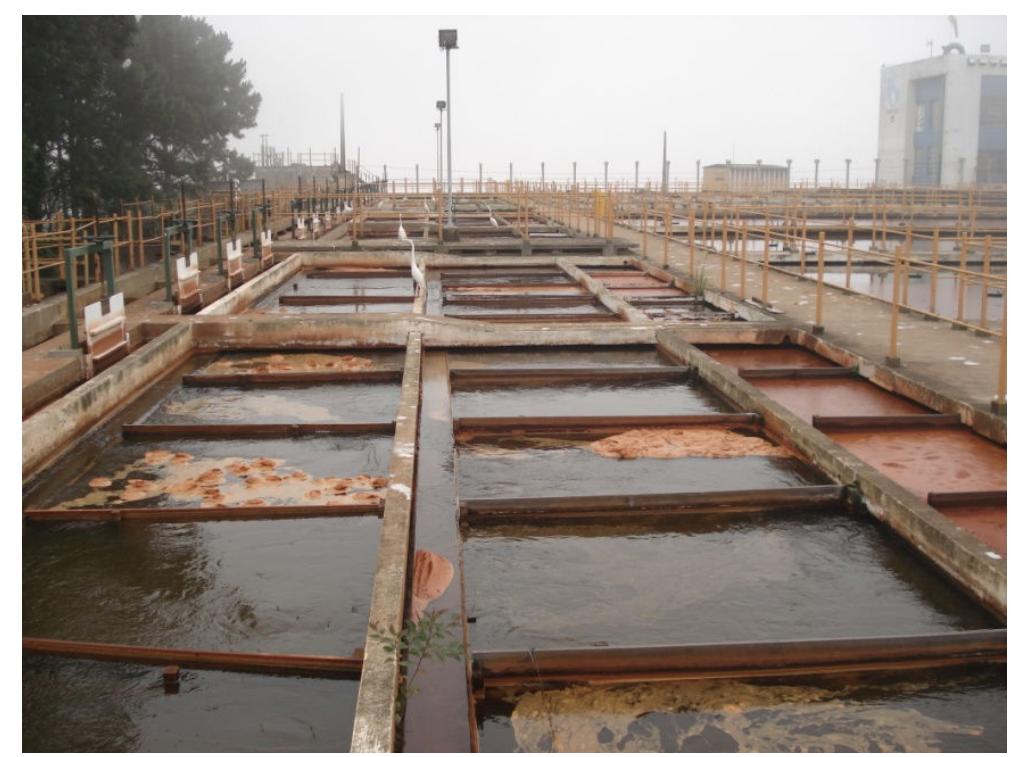

Figura 7 - Floculadores hidráulicos da ETA Rio Grande. 
- Sete decantadores híbridos de fluxo horizontal do tipo convencional, hoje adaptados para módulos tubulares, com dimensões 36,9m x 12,5m x 4,9m, que na vazão média garante uma taxa de escoamento superficial em torno de $105 \mathrm{~m}^{3} / \mathrm{m}^{2}$.dia, maior que os $80 \mathrm{~m}^{3} / \mathrm{m}^{2}$.dia considerados suficientes para uma ótima decantação. Porém, as adaptações feitas estão em condições precárias, principalmente em relação à sustentação dos módulos tubulares, acarretando em operação precária destes decantadores;

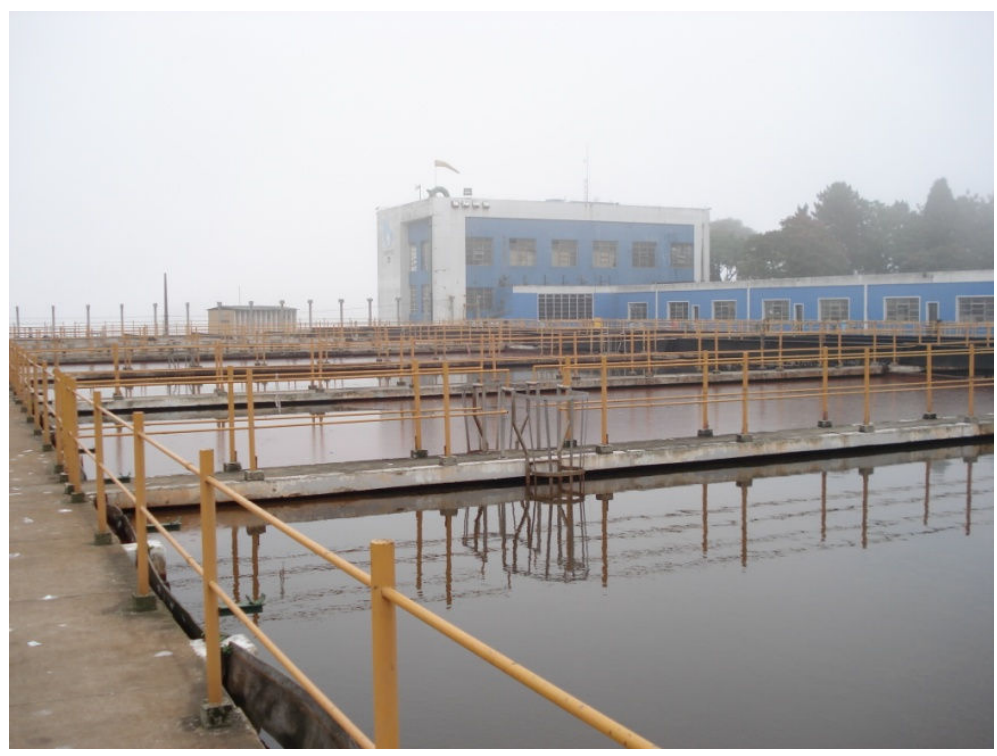

Figura 8 - Decantadores da ETA Rio Grande.

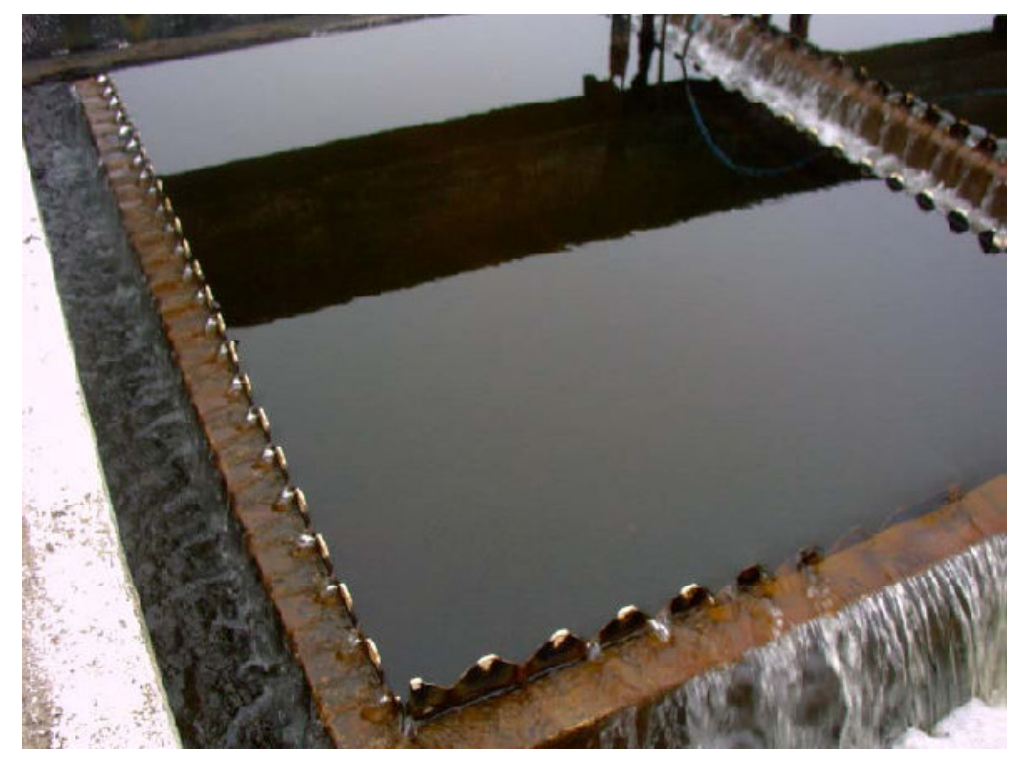

Figura 9 - Água decantada. 
- 14 filtros convencionais de dupla camada de areia-antracito, com taxas de filtração da ordem de $360 \mathrm{~m}^{3} / \mathrm{m}^{2}$.dia, operando, assim, no limite máximo para um funcionamento adequado.

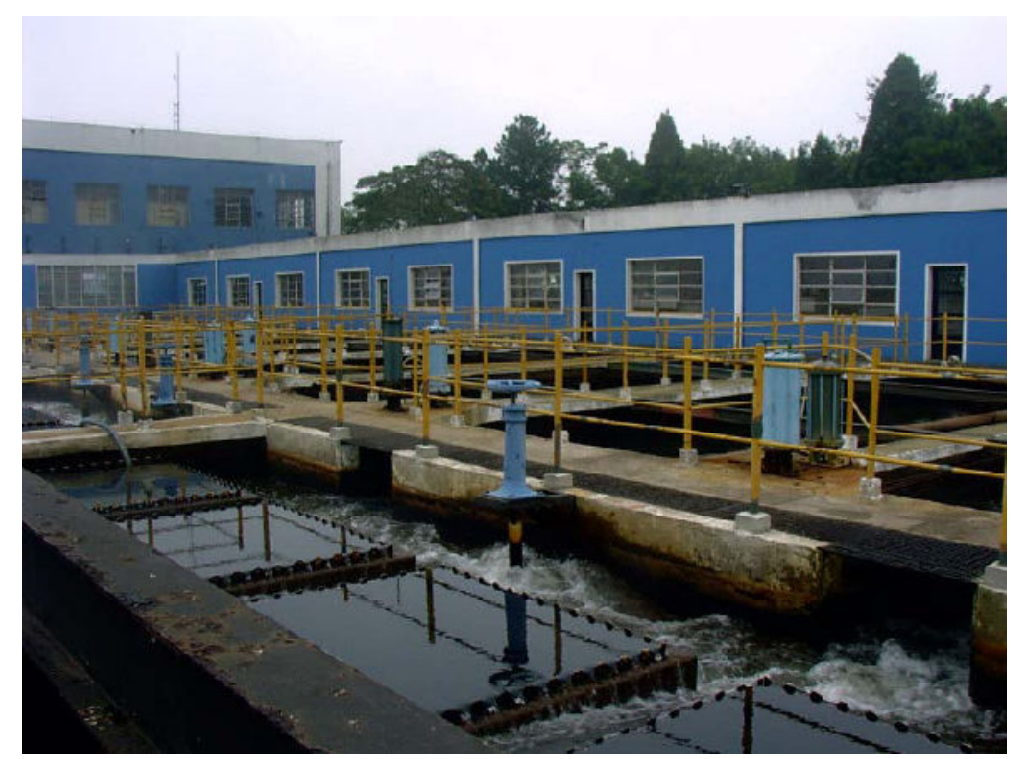

Figura 10 - Filtros da "ala velha" da ETA Rio Grande.

A concepção e projeto da ala "nova" acrescentaram algumas unidades à ETA existente. Tais alterações foram efetuadas de modo que, durante a reforma das unidades existentes, não houvesse nenhum prejuízo ao abastecimento de água, uma vez que, do ponto de vista hidráulico, ambas as alas "antiga" e "nova" trabalham de modo independente. Sendo assim, as novas unidades instaladas correspondem a:

- Dois floculadores mecanizados, cada um com três câmaras de floculação, que permitem maior flexibilidade operacional à ETA ao possibilitarem a variação do gradiente de velocidade em cada câmara; 


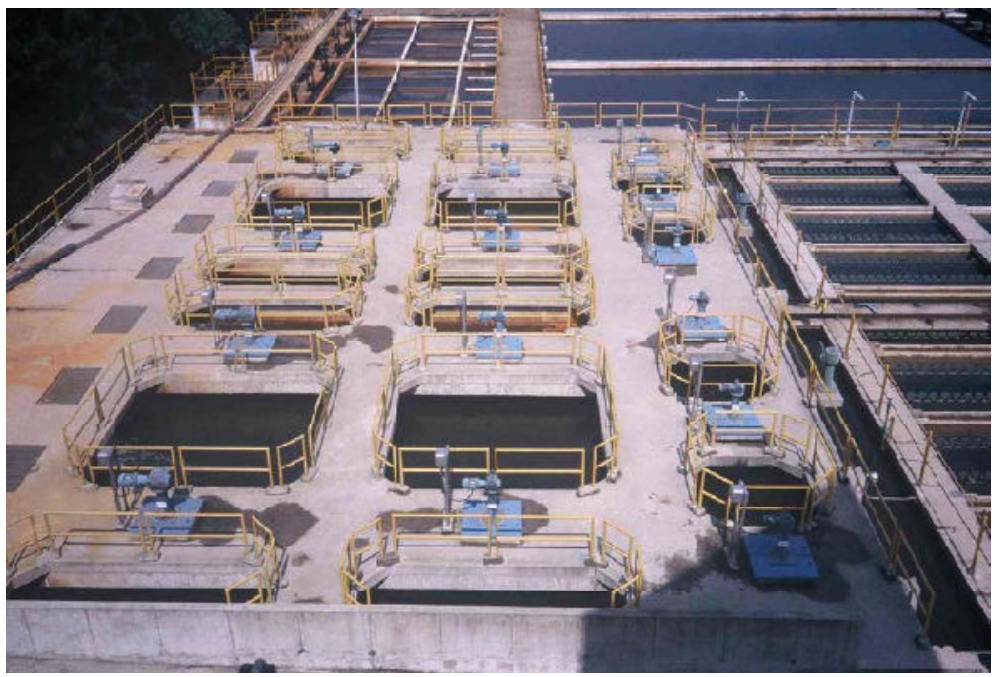

Figura 11 - Floculadores mecanizados da "ala nova" da ETA Rio Grande.

- Dois decantadores de fluxo laminar, com dimensões 30,0m x 12,1m e remoção semicontínua de lodo, o qual é encaminhado para um reservatório de lodo, e deste para a ETE ABC. A velocidade de escoamento entre as placas é da ordem de $11 \mathrm{~cm} / \mathrm{min}$, que seria adequada para um bom funcionamento da decantação (menor que 20 $\mathrm{cm} / \mathrm{min}$ ), não fossem os problemas com a instalação das placas e da operação da ponte removedora de lodo.

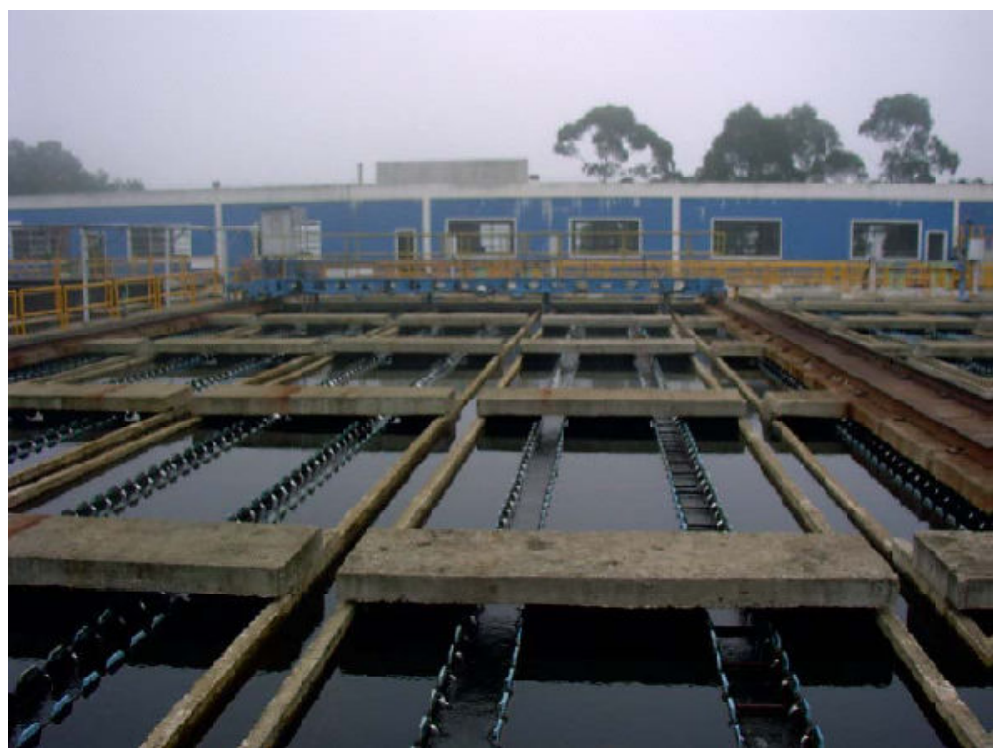

Figura 12 - Decantadores de fluxo laminar da "ala nova" da ETA Rio Grande. 


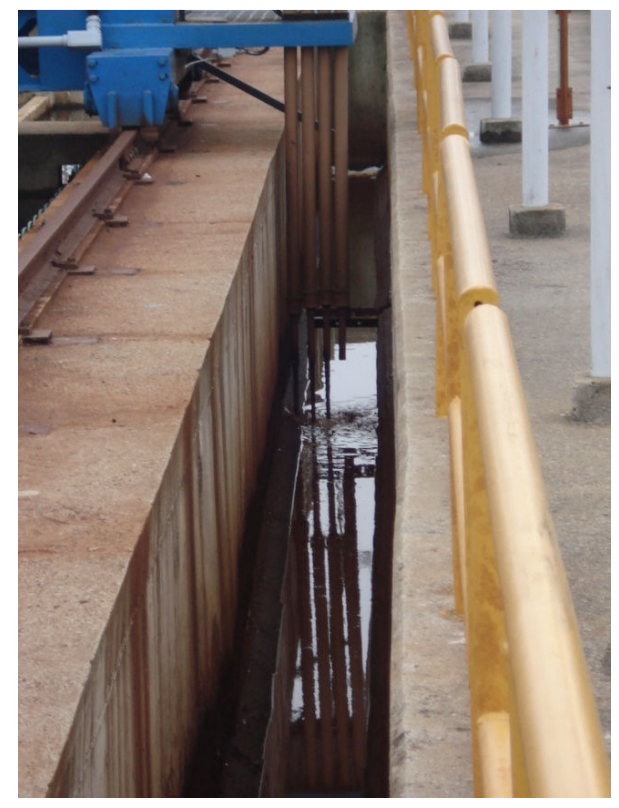

Figura 13 - Canal e tubulação de coleta de lodo.

- Quatro filtros rápidos de areia, do tipo camada profunda, que, operando com a taxa de filtração na ordem de $360 \mathrm{~m}^{3} / \mathrm{m}^{2}$.dia, são subaproveitados, uma vez que este tipo de filtro é projetado para taxas bem maiores (500 a $600 \mathrm{~m}^{3} / \mathrm{m}^{2}$.dia), fato que é compensado pela granulometria inadequada da areia utilizada. A lavagem é feita com ar e água, sendo as águas de lavagem coletadas em canaletas e encaminhadas a reservatórios de acúmulo, para posteriormente voltaram ao início do tratamento;

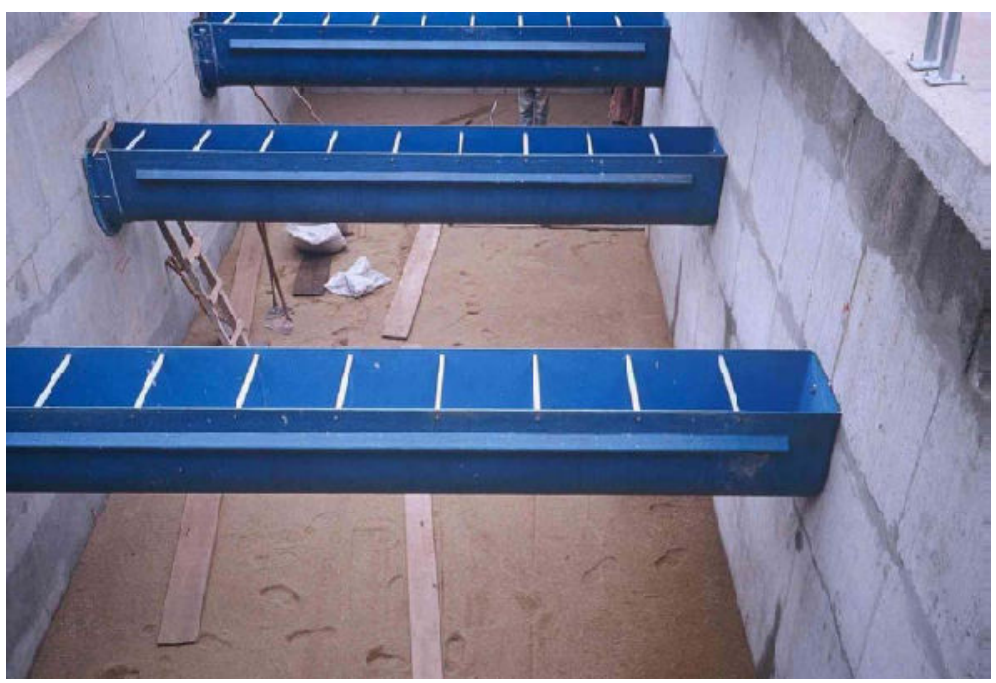

Figura 14 - Calhas de coleta dos novos filtros da ETA Rio Grande. 


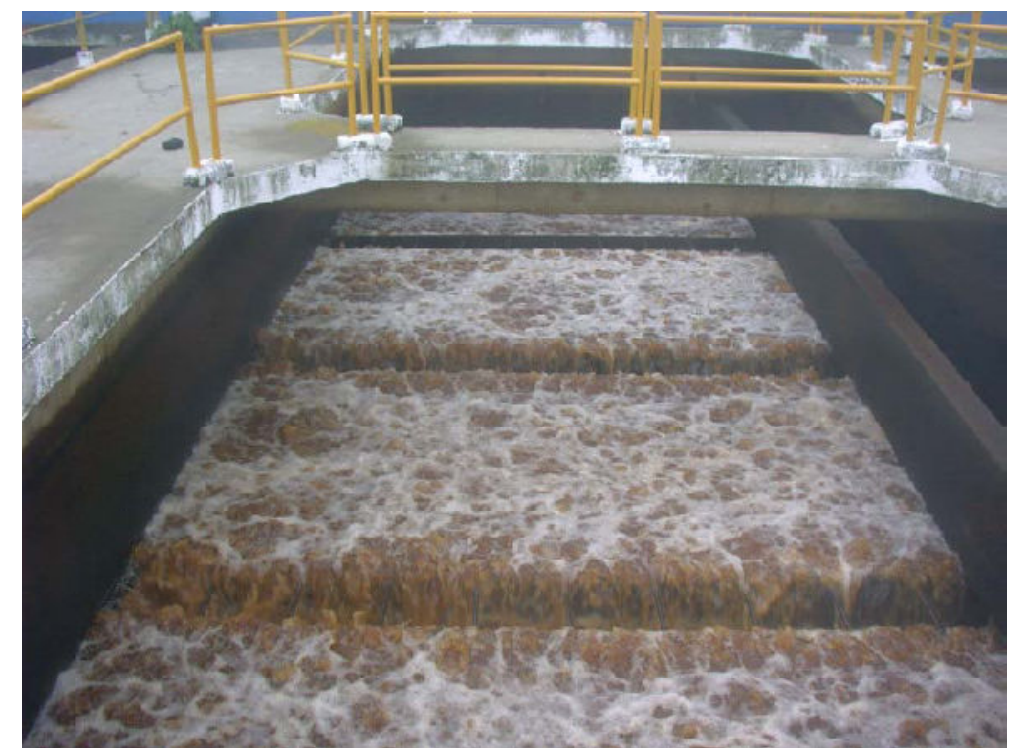

Figura 15 - Retrolavagem dos novos filtros da ETA Rio Grande.

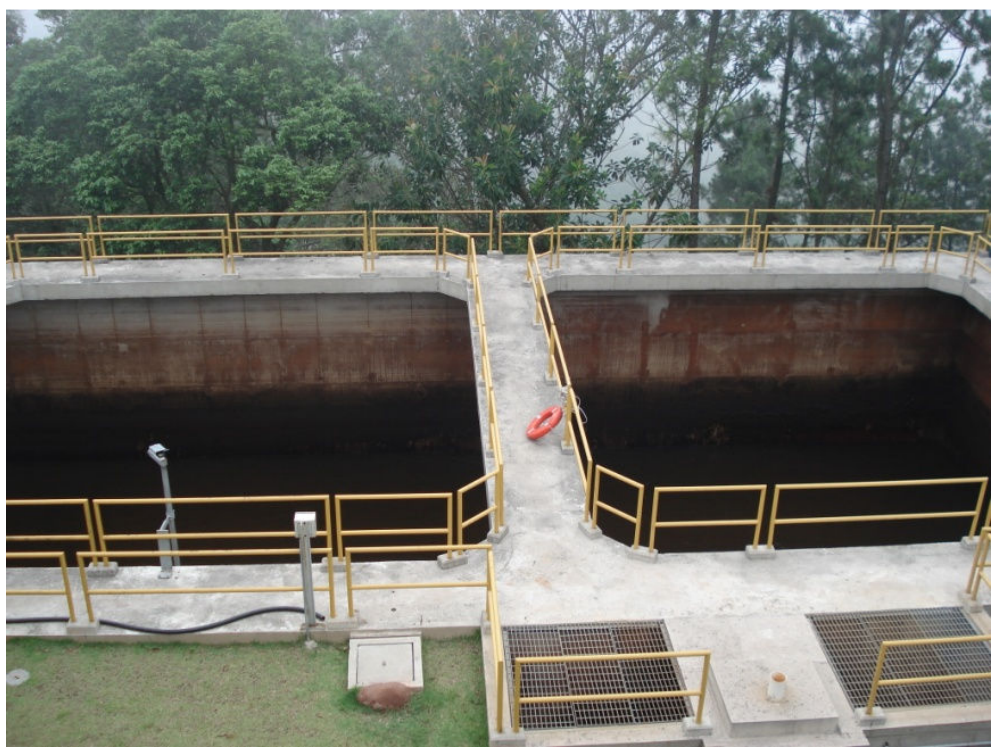

Figura 16 - Novos reservatórios de água de retrolavagem.

- Aplicação de produtos químicos: a água filtrada produzida nos 18 filtros da ETA Rio Grande é encaminhada por recalque ao Reservatório de Distribuição e, antes de seu bombeamento, a mesma recebe a aplicação de flúor, cal como agente pós-alcalinizante e cloro como agente pósdesinfetante, sendo este aplicado em dosagens de 3,0 a $5,0 \mathrm{mg} \mathrm{Cl} / \mathrm{L}$ em época de estiagem, e de até $10 \mathrm{mg} \mathrm{Cl} / 2$ em período chuvoso, para maior remoção de ferro e manganês por oxidação. 
Como subprodutos, a ETA gera água de lavagem dos filtros, que retornam ao início do tratamento, e o lodo nos decantadores, os quais são encaminhados via recalque para o tanque de acumulação, e deste para a ETE ABC.

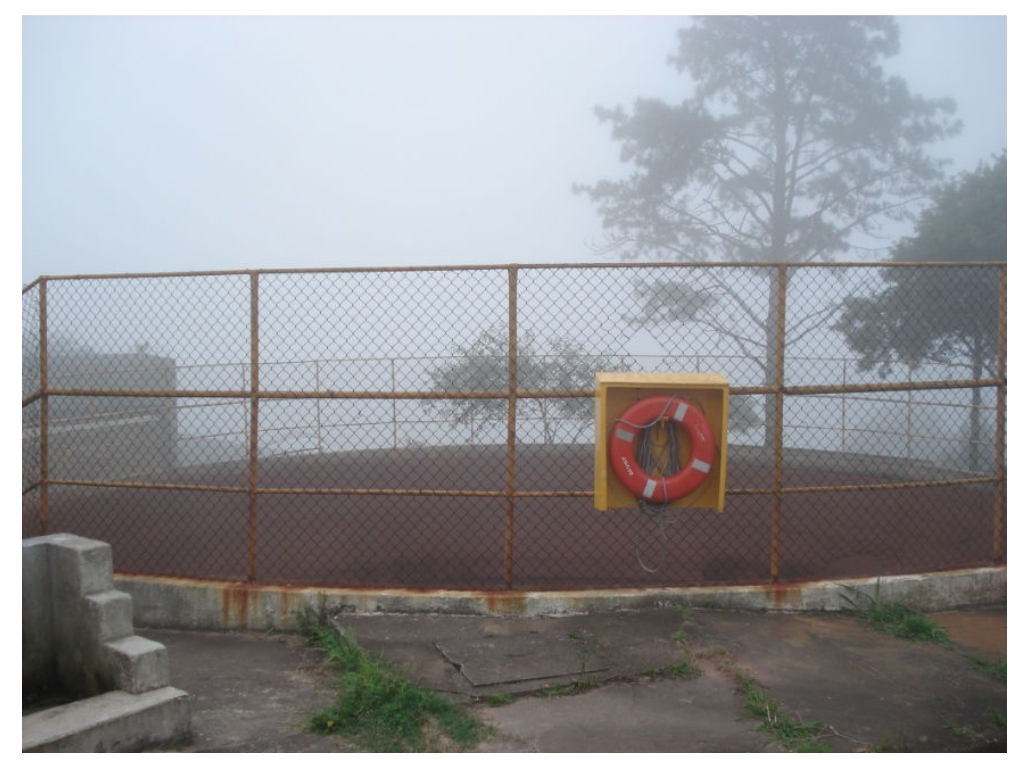

Figura 17 - Vista geral do Reservatório de Lodo.

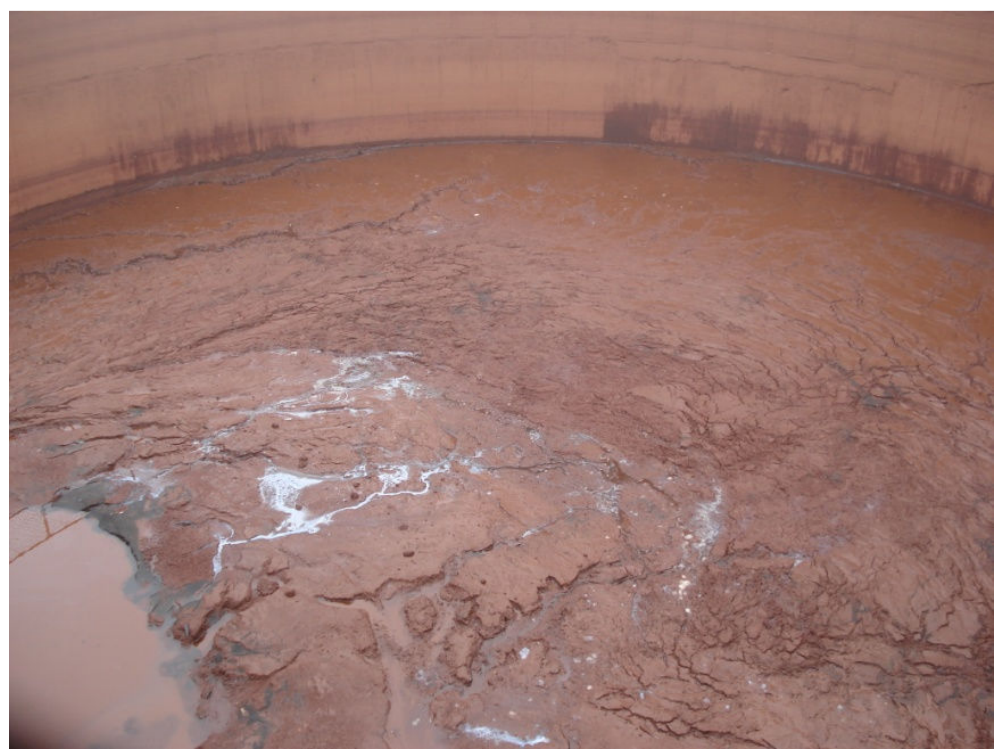

Figura 18 - Lodo armazenado no reservatório.

\subsection{Descritivo da ETE ABC}

A ETE ABC situa-se no município de São Paulo na margem esquerda do Ribeirão dos Meninos, distante cerca de $2 \mathrm{~km}$ da confluência deste curso de água com o Rio 
Tamanduateí. Trata dos esgotos das cidades de Santo André, São Bernardo do Campo, São Caetano do Sul, Diadema e Mauá, acrescido de parte dos esgotos da região sudeste da cidade de São Paulo.

O início da implantação da ETE ABC ocorreu em 1978, prevendo-se inicialmente uma instalação modulada para $6,0 \mathrm{~m}^{3} / \mathrm{s}$ com um total de 2,5 módulos, correspondentes a $15,0 \mathrm{~m}^{3} / \mathrm{s}$ na fase final.

Com a Revisão do Plano Diretor de Esgotos da RMSP, em 1985, a capacidade final da estação foi reduzida de $15,0 \mathrm{~m}^{3} / \mathrm{s}$ para $8,5 \mathrm{~m}^{3} / \mathrm{s}$. Tal capacidade seria alcançada a partir do redimensionamento de um único módulo de $6,0 \mathrm{~m}^{3} / \mathrm{s}$ (agora considerados como dois módulos de $3,0 \mathrm{~m}^{3} / \mathrm{s}$ ), sem prejuízo da eficiência prevista, ressalvando-se os decantadores secundários (acréscimo de mais duas unidades) e digestores (adição de mais quatro unidades).

No entanto, atualmente a ETE trabalha com folga, tratando em média uma vazão de $1,8 \mathrm{~m}^{3} / \mathrm{s}$, operando apenas um módulo de $3,0 \mathrm{~m}^{3} / \mathrm{s}$. Isto resulta na existência de uma capacidade ociosa, motivo pelo qual ela teve condições de receber o lodo da ETA Rio Grande.

As características qualitativas básicas estimadas para cada etapa correspondem a um tratamento de carga de $77.760 \mathrm{~kg} / \mathrm{dia}$ de DBO e de SST para a etapa atual (um módulo, vazão de $3,0 \mathrm{~m}^{3} / \mathrm{s}$ ) e uma carga de $220.320 \mathrm{~kg} / \mathrm{dia}$ de DBO e de SST para a operação final.

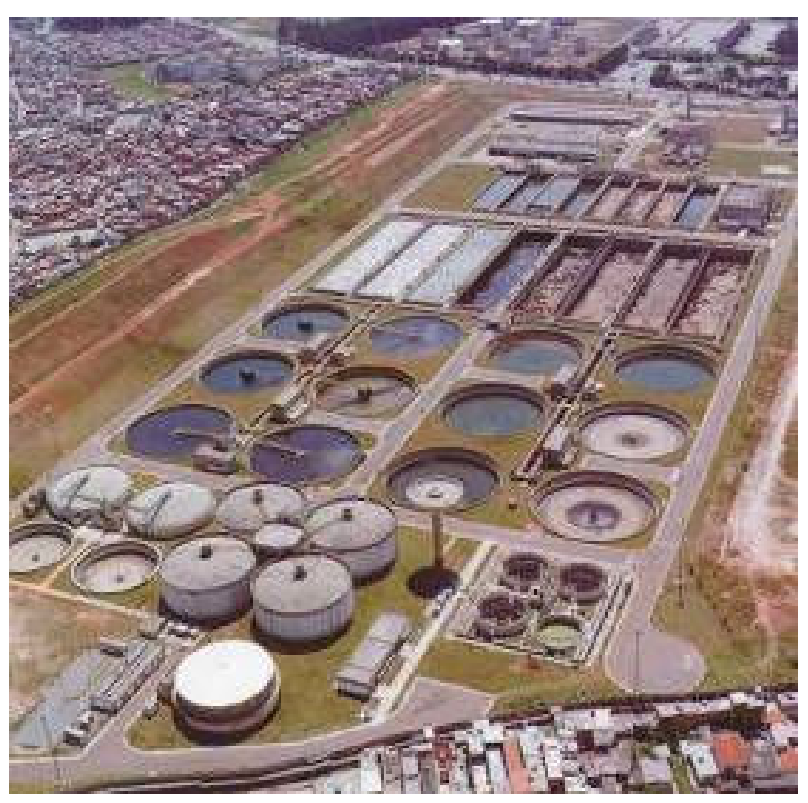

Figura 19 - Vista aérea da ETE ABC. 
O processo de tratamento da ETE ABC é o de lodos ativados convencional, sendo constituído por duas fases: líquida e sólida. A eficiência de remoção prevista em projeto é de $90 \%$ tanto para a carga orgânica quanto para os sólidos em suspensão.

A fase líquida engloba os tratamentos preliminares, primário e secundário convencionais. A fase sólida é formada pelo tratamento preliminar, tratamento do lodo e desidratação mecânica. Na Figura 20 a seguir, segue um fluxograma esquemático do processo de tratamento na ETA ABC. Em linhas gerais, cada etapa do processo é formada por (HIDROSERVICE, 1998; SABESP, 2005a): 


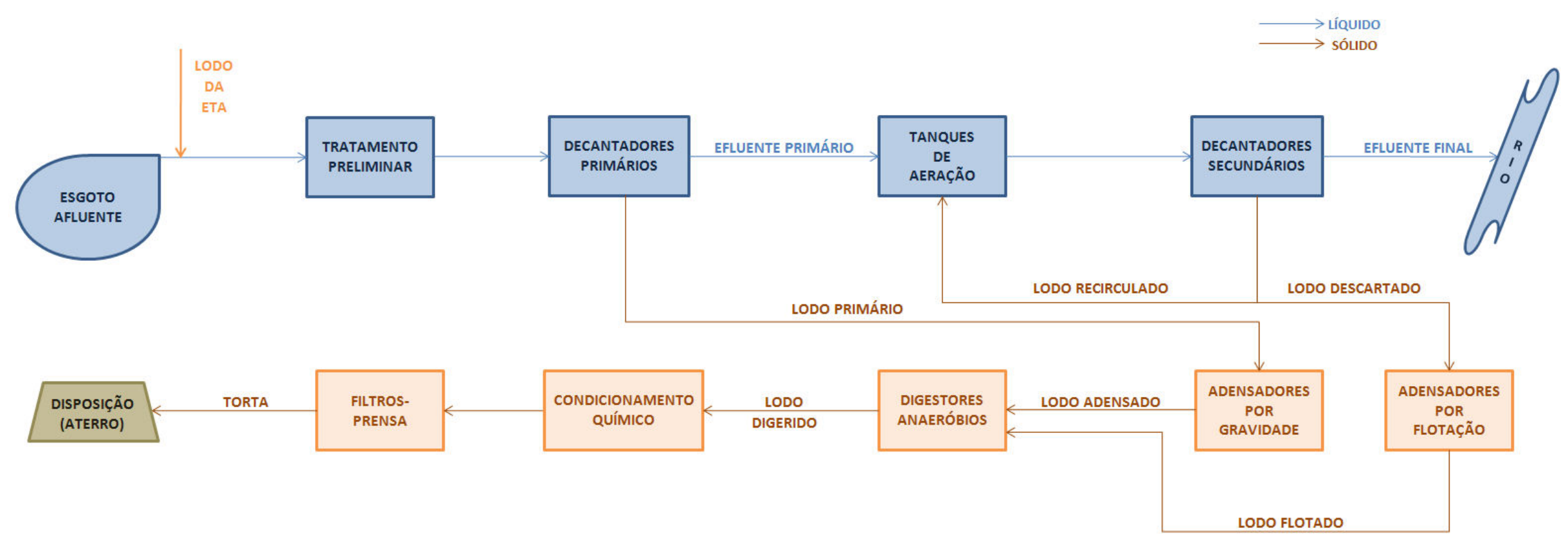

Figura 20 - Fluxograma esquemático da ETE ABC. 


\subsubsection{Fase Líquida}

Tratamento Preliminar:

Gradeamento: após o bombeamento na Estação Elevatória Final, o esgoto afluente à ETE chega por uma tubulação de $1.200 \mathrm{~mm}$ ao canal de gradeamento, por onde passa por duas grades de $25 \mathrm{~mm}$. Retira-se assim o material sólido mais grosseiro, o qual é transportado via esteira transportadora para caçambas, seguindo daí para um aterro sanitário;

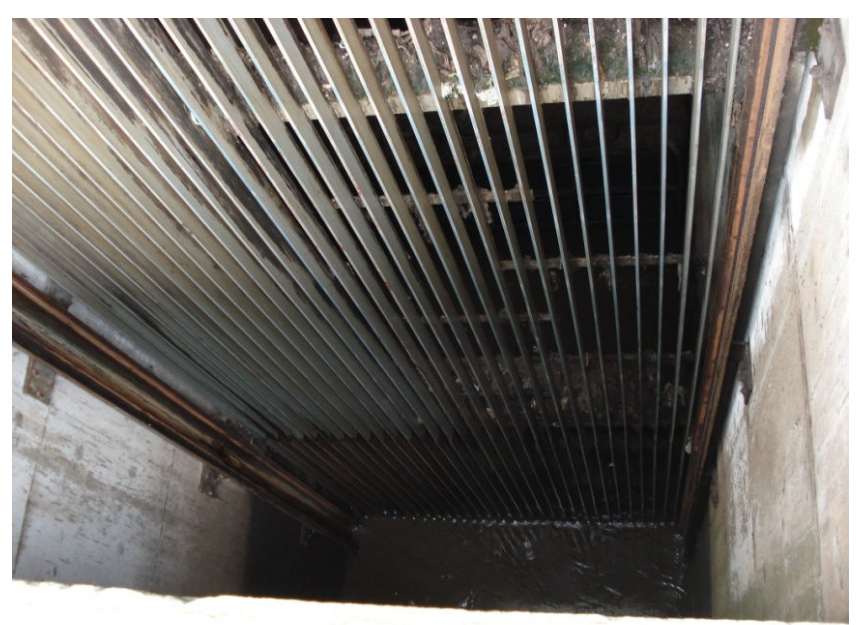

Figura 21 - Instalações de gradeamento.

Caixas de Areia Aeradas: são utilizadas duas das três caixas construídas, cada uma com dimensões $27,0 \mathrm{~m} \times 9,0 \mathrm{~m} \times 4,5 \mathrm{~m}$. A aeração ocorre via difusores de bolhas grossas e a remoção de areia é feita por meio de clam-shell;

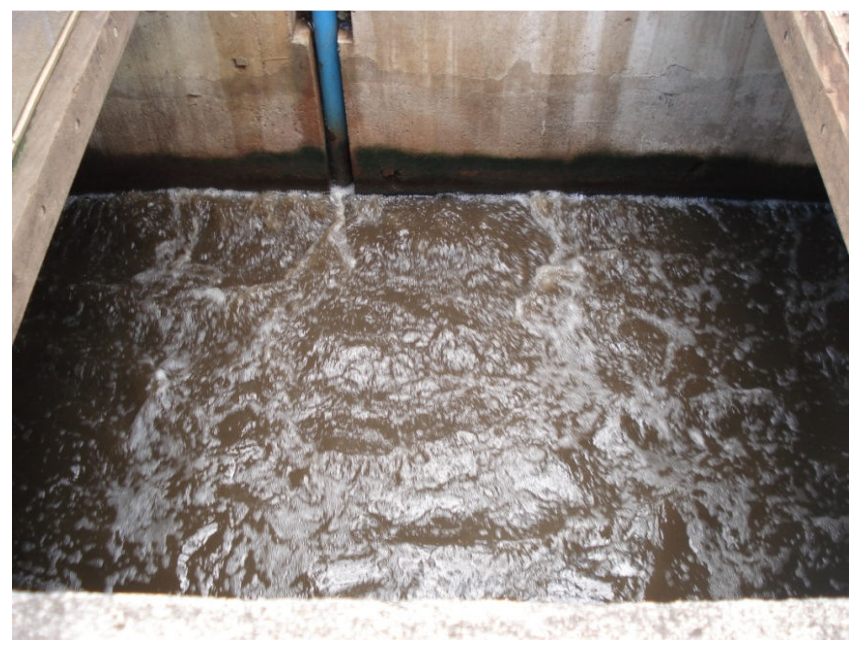

Figura 22 - Caixa de areia aerada. 


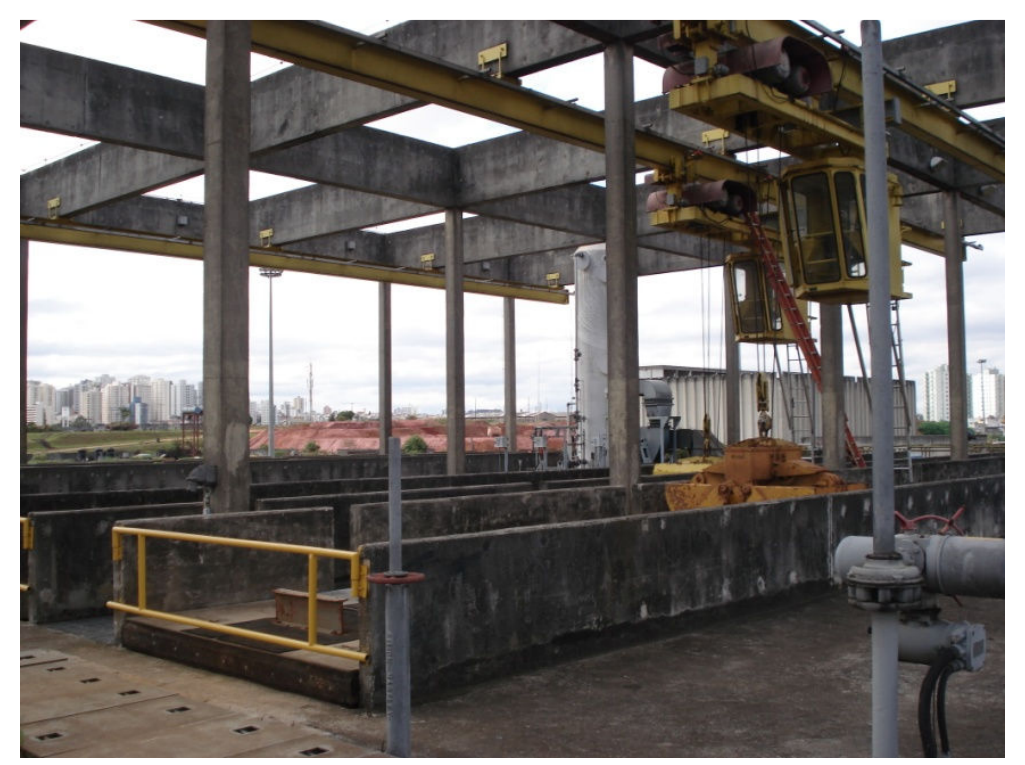

Figura 23 - Clam-shell para retirada de areia.

Tratamento Primário:

Decantadores Primários: há oito tanques para sedimentação, cada um com dimensões $75,0 \mathrm{~m} \times 18,0 \mathrm{~m} \times 3,5 \mathrm{~m}$, dos quais 4 estão em operação. A remoção de lodo primário ocorre por um raspador mecanizado, que também remove escuma da superfície. Dos poços de acumulação de lodo (três para cada decantador), este é bombeado para os adensadores por gravidade (uma elevatória para cada dois tanques);

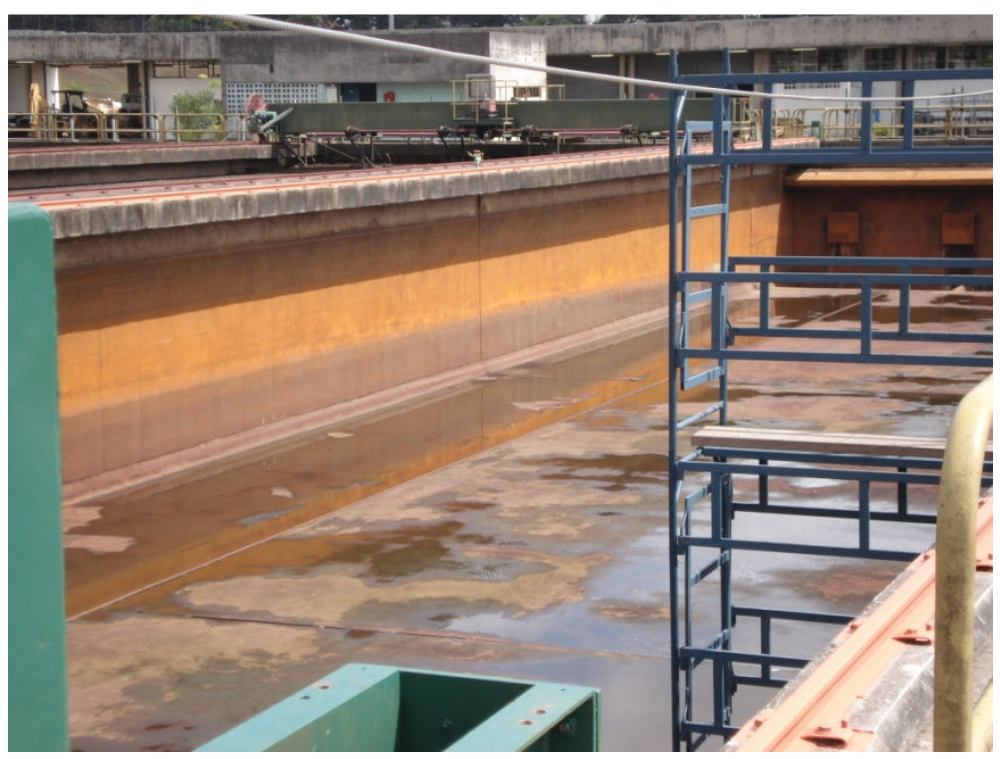

Figura 24 - Decantador primário vazio, para limpeza e manutenção. 


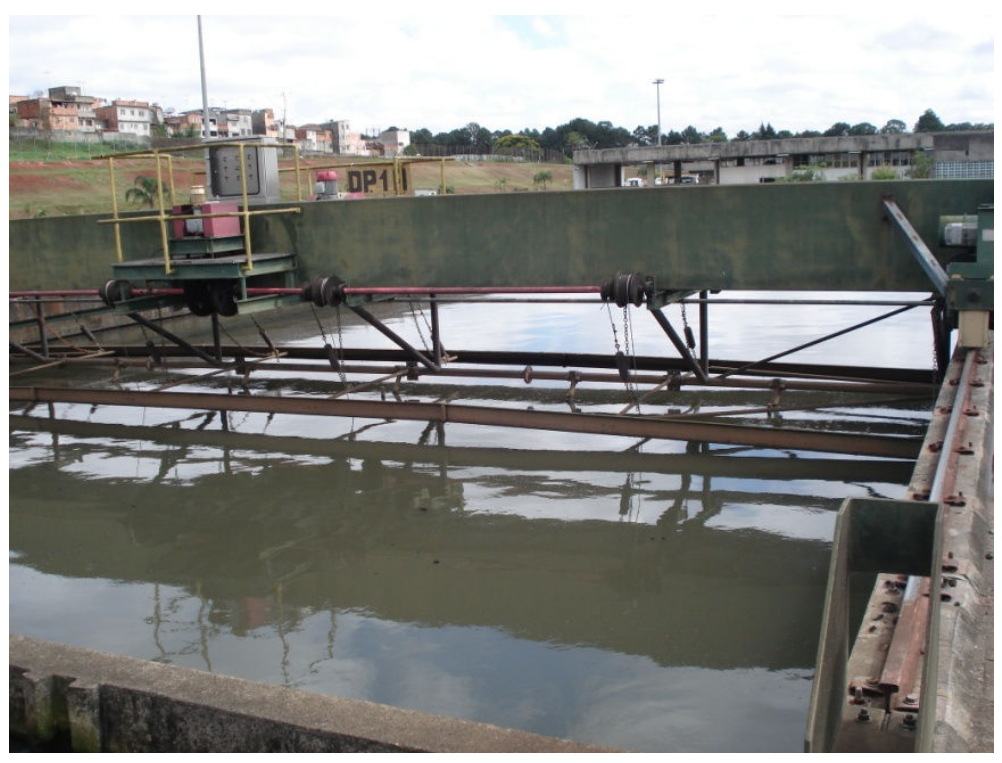

Figura 25 - Decantador primário em operação.

Tratamento Secundário:

Tanques de Aeração: local onde ocorre de fato o tratamento biológico, são quatro tanques operantes, de oito existentes. Cada um dos tanques possui um volume útil de $17.595 \mathrm{~m}^{3}(115,0 \mathrm{~m} \times 25,5 \mathrm{~m} \times 6,0 \mathrm{~m})$. Funcionam em regime de mistura completa e a aeração ocorre por meio de difusores de bolha fina.

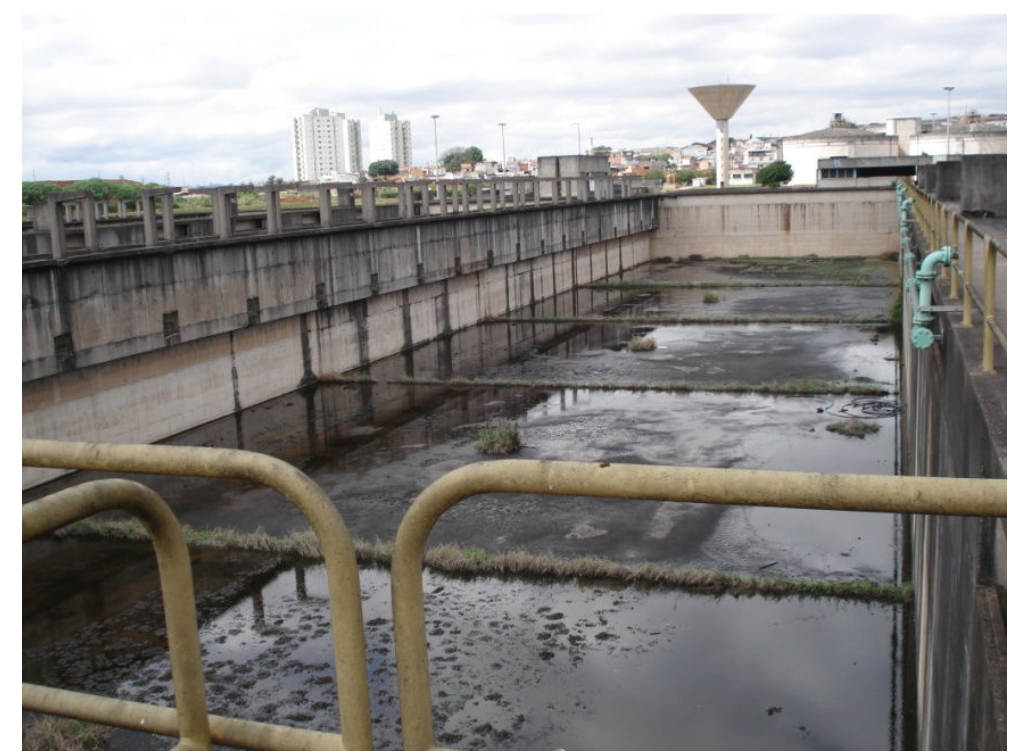

Figura 26 - Tanque de aeração inoperante da ETE ABC.

Decantadores Secundários: o efluente dos tanques de aeração chega aos seis decantadores secundários circulares operantes por canais aerados. Cada um dos decantadores possui $46,0 \mathrm{~m}$ de diâmetro e a remoção de lodo é feita por uma ponte 
giratória, que encaminha o lodo para o centro do tanque, de onde aquele é bombeado em parte para a linha de retorno aos tanques de aeração e parte para os adensadores por flotação. O efluente líquido final é recolhido em canais periféricos e chega, através de uma tubulação de $800 \mathrm{~mm}$, ao canal efluente final, que o leva ao Córrego dos Meninos.

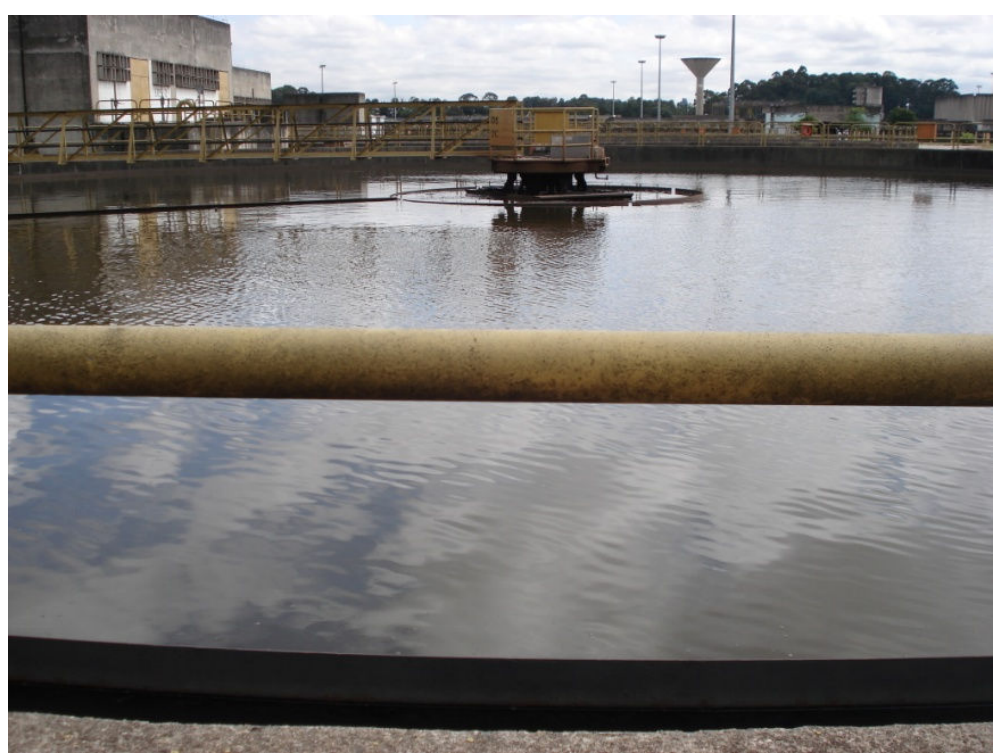

Figura 27 - Vista geral de um decantador secundário da ETE ABC.

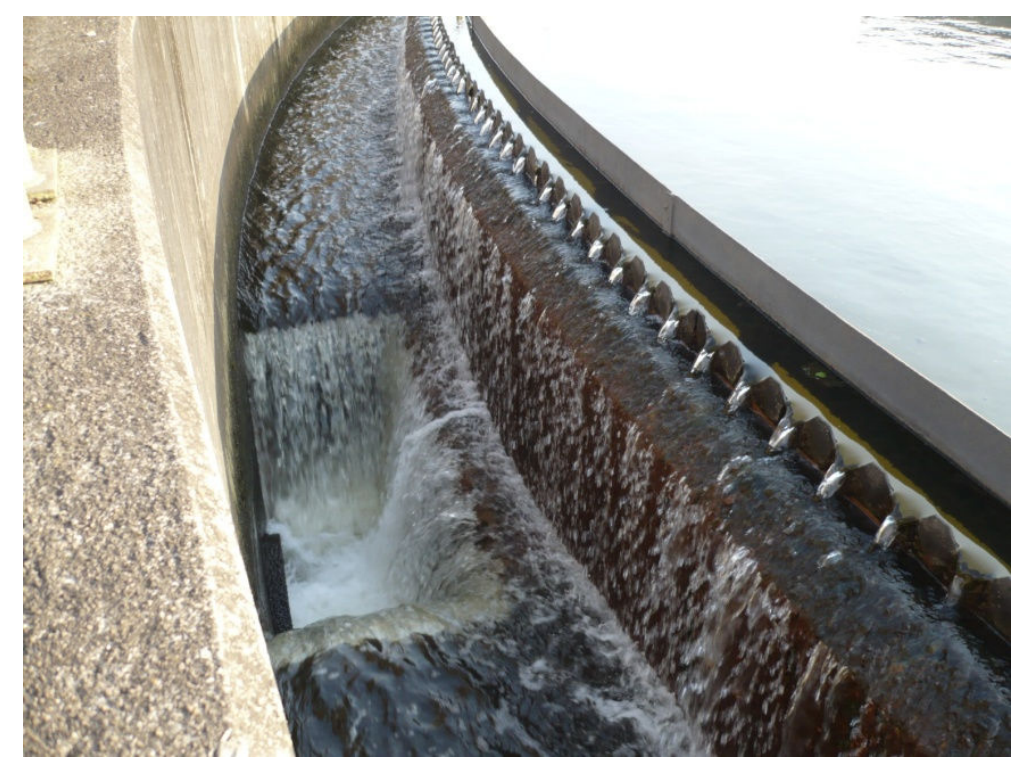

Figura 28 - Detalhe da saída de efluente final, clarificado, da ETE ABC. 


\subsubsection{Fase Sólida}

Adensadores por Gravidade: recebe por bombeamento o Lodo Primário com teor de sólidos entre $2 \%$ e $4 \%$, adensando-o até cerca de $4 \%$ a $5 \%$, sendo então encaminhado para os digestores anaeróbios. São quatro tanques circulares, com $29 \mathrm{~m}$ de diâmetro e 3,50 m de profundidade.

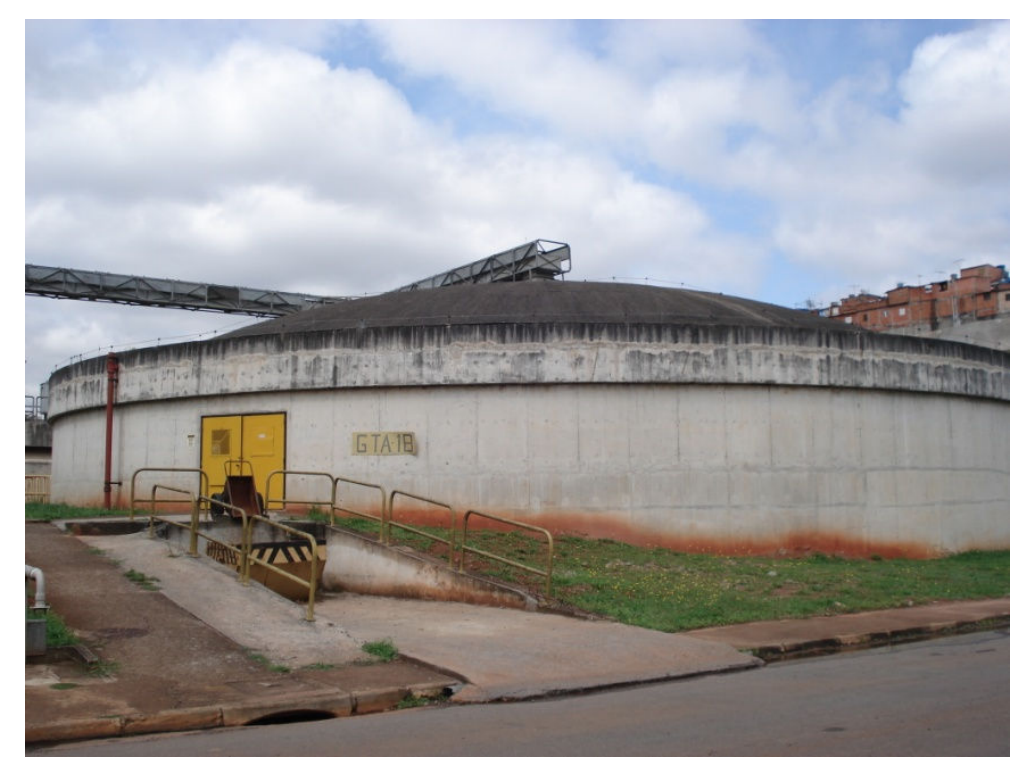

Figura 29 - Adensador por gravidade.

Flotadores por Ar Dissolvido: são três tanques circulares, diâmetro 14,0m e 3,0m de profundidade, que recebem o excesso de Lodo Biológico Secundário, adensando-o a um teor de sólidos de $3 \%$ a $4 \%$ para assim encaminhá-los aos digestores. 0 processo de flotação ocorre através da injeção de ar que carrega as partículas de lodo para a superfície, sendo estas removidas por raspadores superficiais e enviadas a poços de lodo, seguindo daí para os digestores.

Digestores Anaeróbios: recebem os lodos dos adensadores e flotadores, para estabilização do conteúdo orgânico dos mesmos, a qual ocorre em duas etapas: digestão e adensamento. Foram construídos 4 tanques circulares, cada um com $33 \mathrm{~m}$ de diâmetro e $12,3 \mathrm{~m}$ de altura, resultando em um volume útil de $10.520 \mathrm{~m}^{3}$ cada. Durante o processo de digestão, a matéria orgânica é consumida por microrganismos anaeróbios, gerando biogás, o qual é utilizado, após compressão, para homogeneização do lodo contido nos tanques. O excesso de biogás é enviado 
ao gasômetro, onde é então armazenado para ser utilizado como combustível do sistema de aquecimento do lodo ou então é queimado.

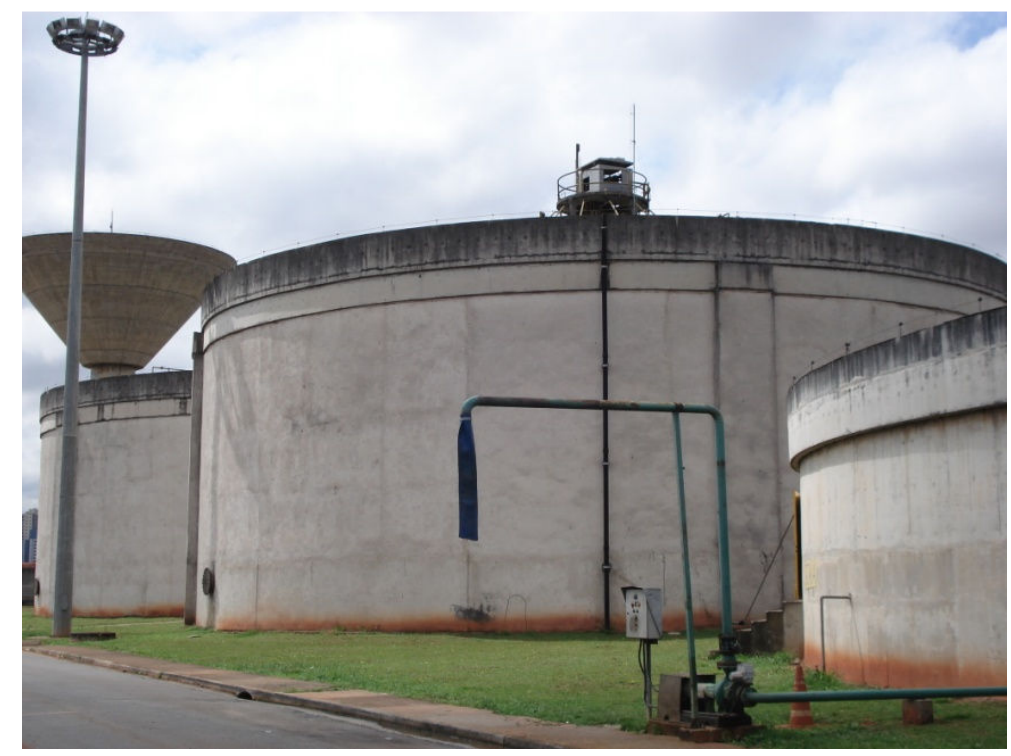

Figura 30 - Digestores de lodo.

Condicionamento Químico do Lodo: com a finalidade de melhorar as condições na etapa de desaguamento, os lodos digeridos recebem uma dosagem de cal e cloreto férrico. O sistema de condicionamento é formado por um tanque de homogeneização do lodo, provido de agitadores, dois tanques de condicionamento com misturadores rápidos, um tanque de lodo condicionado, dois silos de cal e dois tanques de cloreto férrico.

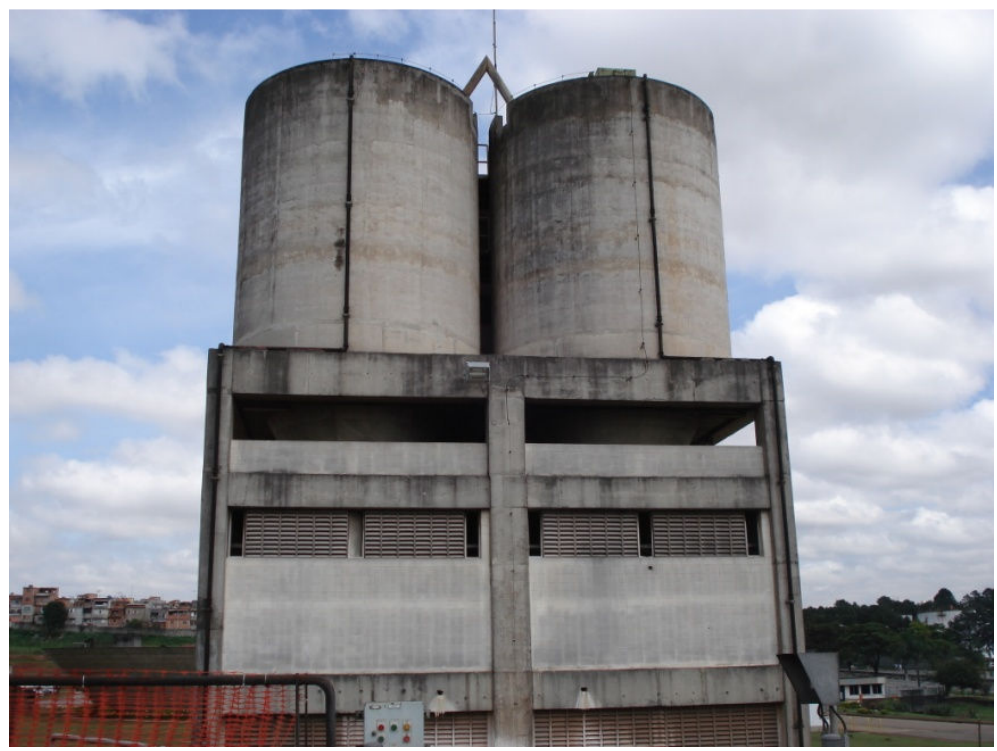

Figura 31 - Silos para armazenamento de cal. 


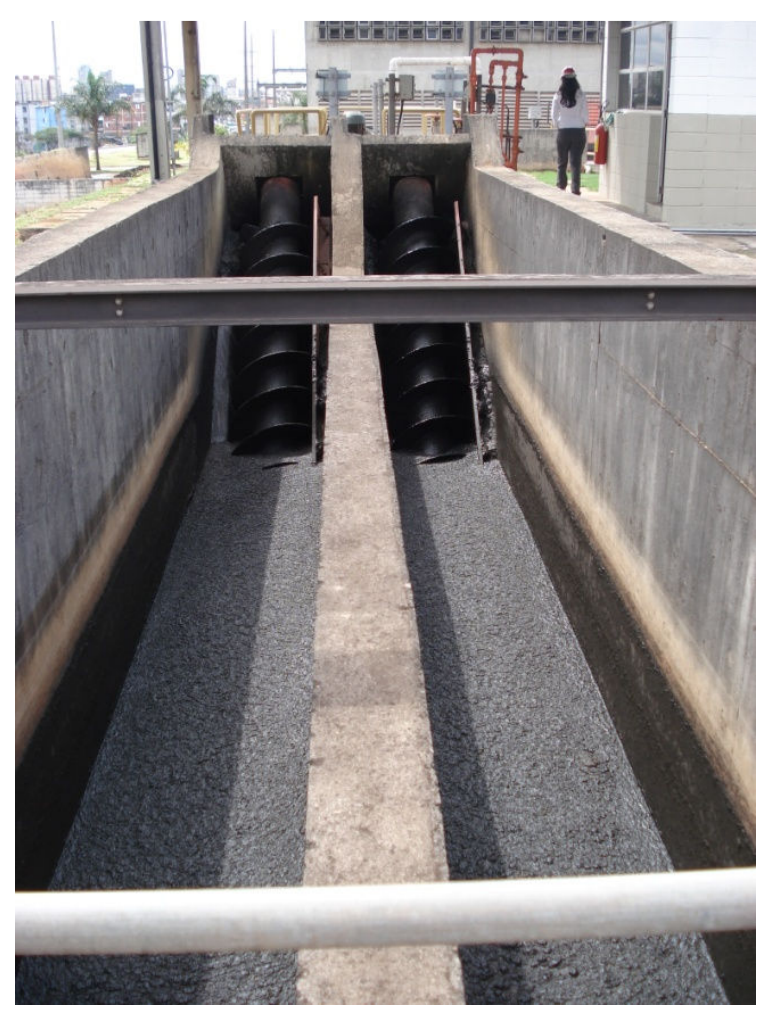

Figura 32 - Canal de recalque para o tanque de condicionamento.

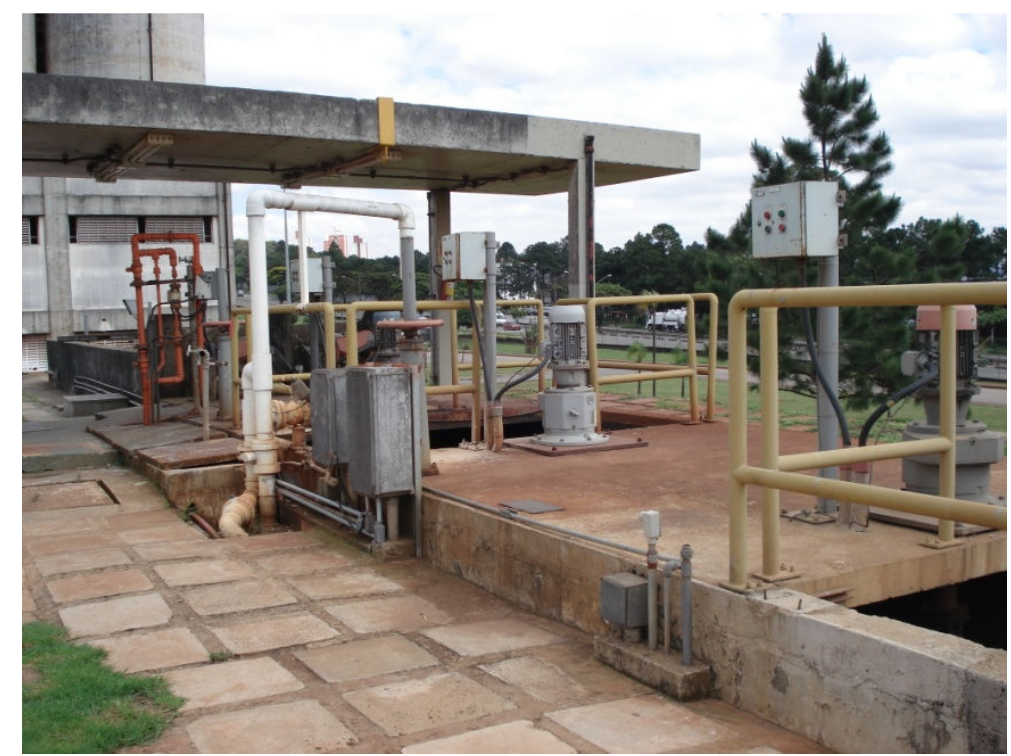

Figura 33 - Instalações de aplicação de produtos químicos no condicionamento do lodo da ETE ABC.

Desidratação do Lodo com Filtros-Prensa de Placas: a última etapa do processo de tratamento do lodo na ETE ocorre em dois filtros-prensa de placas (150 placas cada um, $4 \mathrm{~m}^{2} /$ placa), os quais elevam o teor de sólidos do lodo condicionado até cerca de $40 \%$. Após a desidratação mecânica, a torta de lodo é transportada por quatro correias até a área da qual será levada ao aterro sanitário. 


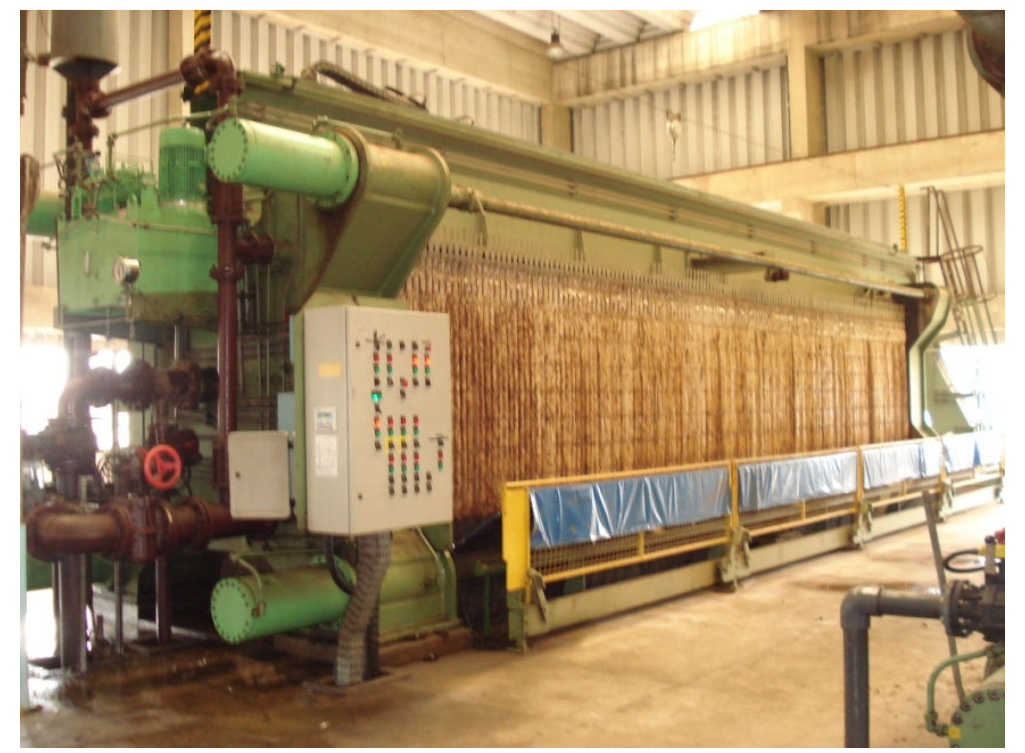

Figura 34 - Filtro-prensa da ETE ABC.

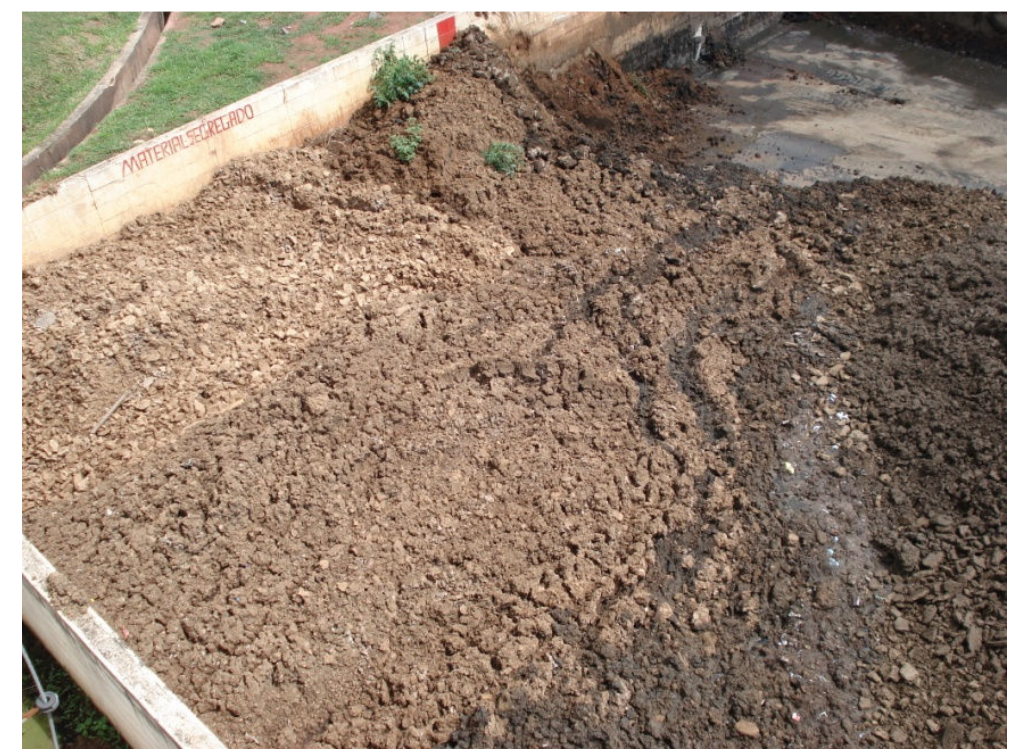

Figura 35 - Torta desidratada, pronta para disposição final em aterro.

A ETE conta ainda com alguns sistemas auxiliares: estação de reuso para água de utilidades, subestação elétrica, edifício de sopradores, instalações de tratamento de gases e controle de odores, redes de drenagem (de fundo das unidades e pluvial) e sistema de Supervisão e Controle. 


\subsection{Descrição do histórico do lançamento de lodo da ETA na ETE}

Tendo em vista que a ETE $A B C$ tem maior capacidade de tratamento em relação ao que hoje ela trata, além do fato de na ETA Rio Grande não haver área suficiente para a construção de instalações de tratamento de fase sólida e ser necessário revolver a sua questão da disposição final de seus lodos, em janeiro de 2007 começou-se a lançar os mesmo na ETE ABC.

O transporte de lodo é feito por conduto forçado, por gravidade, diâmetro de 200mm, em PEAD, denominado "lododuto".

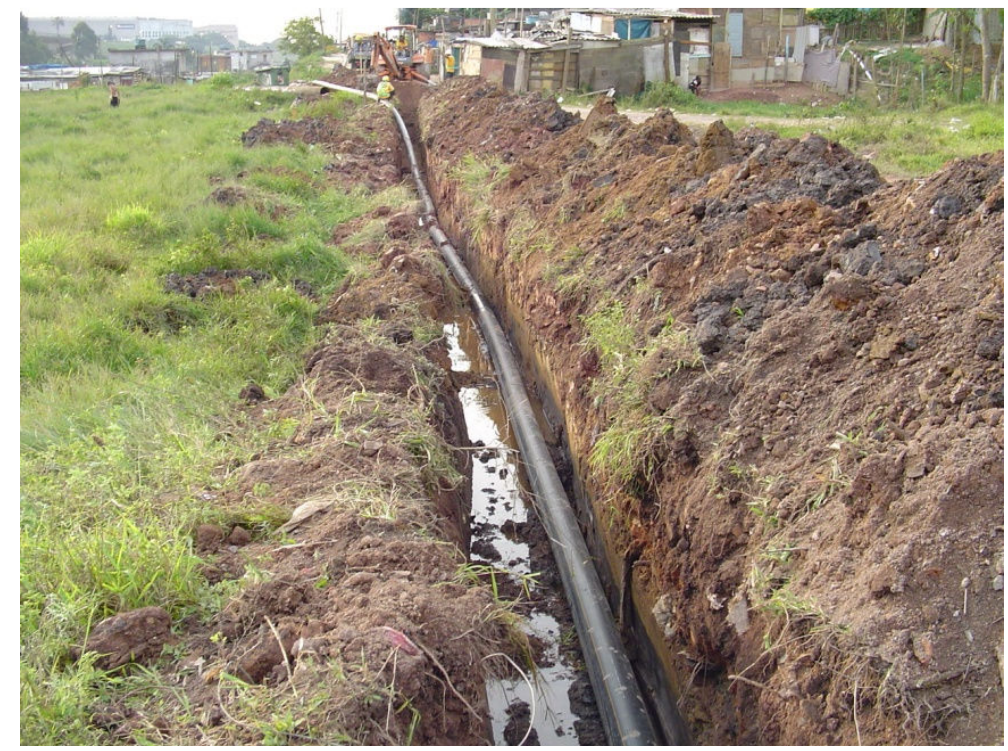

Figura 36 - Lododuto.

Apesar de iniciado o lançamento há cerca de quatro anos, não se sabe ao certo o quanto esta prática está impactando os processos envolvidos no tratamento de esgotos na ETE $A B C$, sendo necessária então uma melhor análise e avaliação destes impactos.

Além do lodo da ETA Rio Grande, a ETE ABC passou a receber, em março de 2008, outro efluente não doméstico crítico: chorume, emitido em aterro sanitário operado pela Solvi. Como seus efeitos sobre o tratamento de esgotos na ETE são diversos em relação aos do lodo da ETA, o período de análise de dados - apresentados a seguir - se estende então esta data. 
Por fim, é importante considerar a diferença de magnitude entre as duas estações consideradas: a vazão de água tratada na ETA Rio Grande é de 3 (três) vezes o valor de vazão de esgoto na ETE ABC. Caso o lançamento do lodo da ETA se mostre viável, sem causar prejuízos ao funcionamento da ETE e na qualidade do seu efluente final, pode-se indicar esta prática em situações em que se tem apenas uma ETA e uma ETE no município, de modo que suas vazões são praticamente iguais (salvo parcela de retorno e infiltrações). São casos bastante frequentes no Brasil, que podem ter melhor destinação dos lodos e sobrecarregar menos os aterros sanitários. Ressalta-se que isto é válido desde que as estações possuam configuração de processos de tratamento bastante semelhantes ao adotado na ETA Rio Grande (tratamento convencional completo de água para abastecimento) e na ETE ABC (sistema de lodos ativados convencional, operando com idade do lodo em torno de quatro dias e taxa de reciclo de lodo de aproximadamente $80 \%$ ), uma vez que processos diferentes podem gerar impactos diversos, conforme visto no item 3.3. É importante considerar também que a vazão de lodo da ETA Rio Grande equivale a apenas $0,1 \%$ da vazão tratada na $E T E A B C$, e esta opera com certa capacidade ociosa (em torno de $50 \%$ do total instalado).

\subsection{Dados utilizados e métodos de análise}

Como base de dados principal para este trabalho, foram utilizados os chamados "Relatórios Gerenciais" da ETE ABC, organizados na forma de planilhas Excel, e tabelas operacionais da ETA Rio Grande (SABESP, 2005b, 2006, 2007, 2008). Nestes relatórios, organizados anualmente pela Sabesp, são apresentadas informações mensais relativas à:

- Eficiência nos processos de tratamento na ETE, representada pelas concentrações dos parâmetros típicos no afluente e no efluente nas diversas unidades da estação. Tais parâmetros são obtidos pelo monitoramento periódico das estações, em seus respectivos Laboratórios; 
- Indicadores relativos a produtos e serviços, como consumo de produtos químicos, vazão afluente, entre outros;

- Parâmetros operacionais nas diversas operações unitárias dos respectivos processos de tratamento;

- Outros dados: no caso da ETE ABC, análises mais específicas no efluente e no lodo (metais, por exemplo), parâmetros microbiológicos, relatório de ocorrências na ETE, etc.

Em relação à ETA Rio Grande, analisou-se o processo de tratamento no que se refere a:

- Qualidade da água bruta ao longo do período estudado;

- Variações operacionais no tocante à dosagem de coagulantes.

Com isso, avaliou-se a produção de lodo na ETA e as características deste em termos vazão, concentração de sólidos, etc. -, estimadas pelas diversas equações disponíveis na literatura e apresentadas no capítulo 1.

No caso da $E T E A B C$, analisaram-se, via comparação entre a situação antes do lançamento do lodo da ETA Rio Grande na ETE - período controle (relatórios de 2005 e 2006) -, e a situação após o início deste lançamento período com lodo (relatórios de 2007 a março de 2008) -, os seguintes dados relacionados a pontos de amostragem específicos na ETE e que possibilitam compreender as diversas ocorrências no processo de tratamento:

- Esgoto bruto: foram analisadas as vazões afluentes à ETE e as concentrações afluentes de DBO, DQO, NTK (nitrogênio total Kjeldahl), P (fósforo total), Ferro Total, SST e SSV, a fim de caracterizar o esgoto bruto. Desejou-se analisar também a alcalinidade afluente, porém esta variável não é monitorada neste ponto;

- Efluente primário: foram analisadas as mesmas variáveis que para o esgoto bruto, visando determinar a eficiência de remoção de sólidos, de matéria orgânica e de nutrientes nos decantadores primários, e as características do esgoto afluente aos tanques de aeração; 
- Tanque de aeração: neste ponto foi de interesse compreender o desenvolvimento dos microrganismos, através da concentração de sólidos no tanque, e das características do lodo ativado, através do IVL (índice volumétrico do lodo);

- Efluente Final: foram analisadas as mesmas variáveis do esgoto bruto, para assim se obterem conclusões em relação aos processos de remoção de sólidos, de matéria orgânica, de nitrificação e de remoção de fósforo ocasionados pelo tratamento de fase líquida na ETE ABC como um todo;

- Tratamento de fase sólida: foi analisada a série de sólidos ao longo da linha de tratamento de lodos, nos pontos relativos ao lodo primário, lodo recirculado dos decantadores secundários para os tanques de aeração, lodo afluente aos adensadores por gravidade, lodo afluente aos flotadores, lodo digerido e torta produzida nos filtros-prensa.

Tais variáveis foram obtidas no Laboratório de Análises de ETE $A B C$, que realiza um monitoramento periódico de todo a ETE. A frequência de amostragem das variáveis analisadas é apresentada na Tabela 2 abaixo:

Tabela 2 - Frequência de amostragem no monitoramento da ETE ABC.

\begin{tabular}{|c|c|c|c|c|c|}
\hline \multirow{2}{*}{ Pontos e variáveis } & \multicolumn{4}{|c|}{ Ano } & \multirow{2}{*}{ Observações } \\
\hline & 2005 & 2006 & 2007 & 2008 & \\
\hline \multicolumn{6}{|l|}{ Esgoto bruto } \\
\hline DBO & S & $S$ & $S$ & $S$ & \\
\hline $\mathrm{DQO}$ & D & D & $D$ & $\mathrm{D}$ & \\
\hline SST e SSV & D & D & $\mathrm{D}$ & $\mathrm{D}$ & \\
\hline $\mathrm{P}$ & M & M & M & M & \\
\hline Ferro & M & $M$ & $M$ & $M$ & \\
\hline $\mathrm{NTK}$ e N-NH${ }_{3}$ & $S$ & $S$ & $\mathrm{~S} / \mathrm{M}$ & M & mensal a partir de julho \\
\hline \multicolumn{6}{|l|}{ Efluente primário } \\
\hline DBO & S & $S$ & S & $S$ & \\
\hline DQO & D & $\mathrm{D} / \mathrm{T}$ & $\mathrm{T}$ & $\mathrm{T}$ & \\
\hline SST e SSV & D & $\mathrm{D}$ & $\mathrm{D}$ & D & \\
\hline $\mathrm{P}$ & M & M & $\mathrm{M}$ & M & \\
\hline $\mathrm{NTK}$ e N-NH & $S$ & $S$ & $S / M$ & M & mensal a partir de julho \\
\hline \multicolumn{6}{|l|}{ Tanque de aeração } \\
\hline SST, SSV e IVL & D & D & D & D & \\
\hline
\end{tabular}

D: diária; S: semanal; M: mensal.

Continua. 
Tabela 2 - Frequência de amostragem no monitoramento da ETE ABC (cont.).

\begin{tabular}{|c|c|c|c|c|c|}
\hline \multirow{2}{*}{ Pontos e variáveis } & \multicolumn{4}{|c|}{ Ano } & \multirow{2}{*}{ Observações } \\
\hline & 2005 & 2006 & 2007 & 2008 & \\
\hline \multicolumn{6}{|l|}{ Efluente final } \\
\hline $\mathrm{DBO}$ & $S$ & $S$ & $S$ & $S$ & \\
\hline DQO & $\mathrm{D}$ & $\mathrm{D}$ & $\mathrm{D}$ & $\mathrm{D}$ & \\
\hline SST e SSV & $\mathrm{D}$ & $\mathrm{D}$ & $\mathrm{D}$ & $\mathrm{D}$ & \\
\hline $\mathrm{P}$ & M & $M$ & M & M & \\
\hline NTK & $S$ & $\mathrm{~S}$ & $\mathrm{~S} / \mathrm{M}$ & M & \\
\hline $\mathrm{N}-\mathrm{NH}_{3}$ & $S$ & $S$ & $S$ & $\mathrm{~S}$ & \\
\hline \multicolumn{6}{|l|}{ Linha de lodo primário } \\
\hline SST, SSV & $\mathrm{D}$ & $\mathrm{D}$ & $\mathrm{D}$ & $\mathrm{D}$ & \\
\hline \multicolumn{6}{|l|}{ Linha de lodo recirculado } \\
\hline SST, SSV & $\mathrm{D}$ & $\mathrm{D}$ & $\mathrm{D}$ & $\mathrm{D}$ & \\
\hline \multicolumn{6}{|c|}{ Linha afluente aos flotadores } \\
\hline SST, SSV & $S$ & $S$ & $S$ & $S /-$ & \\
\hline \multicolumn{6}{|c|}{ Linha efluente dos digestores } \\
\hline SST, SSV & $S$ & $S$ & $S$ & $\mathrm{~S} /-$ & \\
\hline \multicolumn{6}{|l|}{ Entrada dos filtros-prensa } \\
\hline ST, SV & $\mathrm{D}$ & $\mathrm{D}$ & $\mathrm{D}$ & $\mathrm{D} / \mathrm{S}$ & \\
\hline \multicolumn{6}{|l|}{ Lodo seco (torta) } \\
\hline TS total & - & - & $-/ D$ & $\mathrm{D}$ & mais de uma medida diária \\
\hline
\end{tabular}

D: diária; S: semanal; M: mensal.

Percebe-se que há uma variabilidade significativa entre as frequências de amostragem e análise das diversas variáveis monitoradas pelo Laboratório da ETE ABC. Assim, a fim de se uniformizar a apresentação dos resultados, foram consideradas as médias mensais para cada variável.

A partir destas, para possibilitar a comparação entre os dois períodos analisados, foram utilizadas as estatísticas básicas - médias, medianas, desvios - e a sua representação gráfica via diagramas tipo box-plot, nos quais apresentam-se também o primeiro e o terceiro interquartil. Nestes diagramas, $\mathrm{O}$ período controle é representado como "ANTES", e o com lodo, "DEPOIS".

De modo a garantir maior embasamento estatístico na comparação entre os dois períodos, para cada uma das variáveis estudadas, a análise gráfica dos box-plot foi complementada com uma sequência de testes, realizados com o auxílio da equipe do CEA - Centro de Estatística Aplicada, afiliado ao 
Departamento de Estatística do Instituto de Matemática e Estatística da USP (IME-USP).

Verificou-se inicialmente se os dados em cada período de estudo eram passíveis de um ajuste através de regressão, a fim de verificar a existência de correlação com o tempo. Utilizou-se, para isso, o modelo de regressão robusta, também conhecido como método dos mínimos quadrados ponderados interativamente, com objetivo de minimizar a influência de valores discrepantes (outliers) no ajuste da reta aos dados (HUBER, 1981).

A avaliação do ajuste foi feita pela homocedasticidade (manutenção da variância) e pela a dispersão dos resíduos. Para as variáveis em que este modelo indicou bom ajuste, realizou-se a comparação entre os períodos controle e lodo, através do valor-p para o coeficiente de inclinação da reta, com valor de significância (a) de 5\% (corte). Assim, pode-se notar se houve tendência de aumento ou diminuição da variável, bem como se houve variação na magnitude destas tendências.

Para as variáveis que não obtiveram bom ajuste nos modelos regressivos e nem diferenças significantes de inclinação entre os dois períodos estudados, considerou-se que se tratava de variáveis independentes que seguem uma distribuição normal, e aplicou-se o teste de homocedasticidade (teste de variâncias - teste $F$ ), para verificar se houve mudança de variância entre os dois períodos estudados. Na sequência, aplicou-se o teste de médias (teste tStudent), utilizando o método que se adequava ao resultado do teste de variância, para verificar se houve mudança no valor médio quando se passa do período controle para o período com lodo (BUSSAB e MORETTIN, 2006).

Maiores esclarecimentos sobre este estudo estatístico desenvolvido com auxílio do CEA são apresentados no Anexo D (ALENCAR et al., 2011).

Assim, é importante ressaltar que nos resultados apresentados no capítulo seguinte, bem como nas conclusões obtidas a partir destes resultados, as comparações realizadas entre os dois períodos estudados possuem maior valor qualitativo do que quantitativo, uma vez que se utilizou de médias mensais (com desvios e coeficientes de variação consideráveis) e da validação pelos testes supracitados. Além disso, a existência de valores consagrados na 
literatura, passíveis de comparação, colaboram para a tais conclusões qualitativas sob o ponto de vista prático da engenharia sanitária.

Importante destacar ainda que o período com lodo apresenta um ciclo completo de dados (o ano de 2007) e outro incompleto, pois se analisa até março de 2008. Por se tratar de apenas três meses, optou-se por manter estes dados, sem ocorrer risco de desbalancear os resultados das estatísticas básicas.

A partir destas análises, foi possível então avaliar o efeito do lançamento do lodo da ETA Rio Grande na ETE ABC sobre os seguintes processos do tratamento biológico por lodos ativados e do tratamento da fase sólida:

- Impacto na eficiência de remoção de matéria orgânica;

- Ocorrência de nitrificação;

- Impacto na eficiência de remoção de fósforo e ferro;

- Impactos ocorridos no tratamento da fase sólida, como produção de lodo, capacidade de adensamento e desidratação.

Além disso, outras análises foram feitas acerca do sistema de tratamento na ETE, baseada em alguns dados não laboratoriais e sim em parâmetros operacionais ou de projeto, a saber:

- Nos decantadores primários: taxa de aplicação superficial - TAS $\left(\mathrm{m}^{3} / \mathrm{m}^{2} . \mathrm{dia}\right)$;

- Nos tanques de aeração: relação A/M (kg DBO/kg SSV.dia) e idade do lodo (dias);

- Nos decantadores secundários: TAS e taxa de aplicação de sólidos - TASol (kg/m².h);

- Nos adensadores por gravidade e flotadores: TAS e TASol;

- Nos digestores: tempo de detenção (dias), quantidade de gás produzida e sua relação com a remoção de SV;

- No condicionamento do lodo: consumo diário ( $\mathrm{kg} / \mathrm{dia})$ de produtos químicos ( $\mathrm{CaO}$ e $\mathrm{FeCl}_{3}$ ); 


\section{RESULTADOS E DISCUSSÕES}

Os resultados serão apresentados da seguinte forma: inicialmente são apresentadas as análises do lodo produzido na ETA Rio Grande no período de estudo do lançamento (janeiro de 2007 a março de 2008). A seguir, serão apresentadas as análises comparativas para caracterizar e avaliar alterações decorrentes da adição do lodo da ETA no esgoto afluente e efluente final da $E T E A B C$, dando atenção à eficiência global do tratamento na ETE.

Por fim, baseando-se nestes últimos, serão apresentados os resultados operacionais de cada unidade do tratamento de fase líquida e de fase sólida, de modo a justificar as alterações na qualidade do efluente lançado e do lodo produzido.

\subsection{Lodo produzido na ETA Rio Grande}

Os dados de produção média diária por mês de lodo na ETA Rio Grande, durante o período de janeiro de 2007 a março de 2008, isto é, época em que foi lançado na ETE $A B C$ como principal interferente no tratamento de esgotos domésticos, foram estimados pela equipe de operação da ETA a partir da fórmula do WRC, conforme apresentada no capítulo 3.1:

$P=(1,2 \cdot T+0,07 \cdot C+k \cdot D+A)$

onde, $\mathrm{P}$ representa a produção de sólidos (g matéria seca $/ \mathrm{m}^{3}$ de água tratada), T é a turbidez (UT), C a cor aparente da água bruta (uH), D a dosagem de coagulante $(\mathrm{mg} / \mathrm{L}), \mathrm{k}$ o coeficiente de precipitação (igual a 0,26 quando se usa sulfato de alumínio liquido; 0,66 no caso do cloreto férrico anidro; e 0,81 para o sulfato férrico), e $\mathrm{A}$ a dosagem de outros produtos químicos, como polímeros e $\operatorname{CAP}(\mathrm{mg} / \mathrm{L})$. 
Tabela 3 - Produção média diária por mês de lodo na ETA Rio Grande durante o período de estudo.

\begin{tabular}{cccccccc}
\hline Mês & $\begin{array}{c}\text { Vazão de } \\
\text { água tratada } \\
\text { na ETA } \\
\text { (m³/s) }\end{array}$ & $\begin{array}{c}\text { Dosagem de } \\
\text { Coagulante } \\
\text { (sulfato } \\
\text { férrico- } \\
\text { mg/L) }\end{array}$ & $\begin{array}{c}\text { Dosagem } \\
\text { de } \\
\text { polímero } \\
\text { (mg/L) }\end{array}$ & $\begin{array}{c}\text { Cor } \\
\text { aparente } \\
\text { da água } \\
\text { bruta (uH) }\end{array}$ & $\begin{array}{c}\text { Turbidez } \\
\text { da água } \\
\text { bruta (UT) }\end{array}$ & $\begin{array}{c}\text { Produção de lodo } \\
\text { (kg matéria } \\
\text { seca/m } \mathbf{m}^{3} \text { kg/dia) }\end{array}$ \\
\hline jan/07 & 4,74 & 17,90 & 0,02 & 15,60 & 1,94 & 0,01 & 4.269 \\
fev/07 & 4,84 & 18,49 & 0,01 & 16,24 & 2,23 & 0,01 & 4.615 \\
mar/07 & 4,83 & 18,19 & 0,01 & 26,43 & 3,09 & 0,01 & 5.300 \\
abr/07 & 4,88 & 17,38 & 0,01 & 28,65 & 3,20 & 0,01 & 5.322 \\
mai/07 & 4,72 & 18,11 & 0,03 & 15,15 & 2,53 & 0,01 & 4.557 \\
jun/07 & 4,73 & 16,73 & 0,11 & 14,34 & 2,34 & 0,01 & 4.270 \\
jul/07 & 4,61 & 16,64 & 0,09 & 21,59 & 3,30 & 0,01 & 4.792 \\
ago/07 & 4,74 & 16,56 & 0,08 & 27,62 & 3,17 & 0,01 & 5.030 \\
set/07 & 4,79 & 16,02 & 0,07 & 30,15 & 3,05 & 0,01 & 5.000 \\
out/07 & 4,83 & 17,34 & 0,07 & 56,92 & 5,29 & 0,02 & 7.060 \\
nov/07 & 4,84 & 16,68 & 0,07 & 56,65 & 5,34 & 0,02 & 7.087 \\
dez/07 & 4,71 & 16,83 & 0,07 & 50,49 & 2,40 & 0,00 & 5.310 \\
jan/08 & 4,84 & 16,27 & 0,09 & 73,81 & 3,01 & 0,02 & 6.365 \\
fev/08 & 4,90 & 17,49 & 0,08 & 88,54 & 3,12 & 0,02 & 7.114 \\
mar/08 & 5,08 & 18,29 & 0,07 & 55,64 & 2,50 & 0,01 & 6.173 \\
\hline
\end{tabular}

Observa-se na Tabela 3 que a vazão tratada na ETA manteve-se em torno de um valor médio mesmo com o passar do tempo $\left(4,75 \mathrm{~m}^{3} / \mathrm{s}\right)$. O mesmo pode-se dizer em relação à dosagem de coagulante e a turbidez da água bruta, as quais não apresentaram grandes variações práticas no período estudado. Por sua vez, a dosagem de polímero e a cor aparente da água bruta apresentaram aumento gradual ao longo do tempo.

Percebe-se que a quantidade média diária de lodo produzida é menor que a estimada em Januário e Ferreira Filho (2007), que girava em torno de 9,3 t/dia já no ano de 2003. Isto se deve às modificações ocorridas nas últimas reformas e ampliações da ETA, as quais possibilitaram uma menor geração de lodo (acerto de dosagens, melhora na qualidade da água bruta, descarga otimizada dos decantadores).

Pelo gráfico abaixo (Figura 37), pode-se perceber que a produção de lodo acompanha as variações de vazão tratada na ETA: 


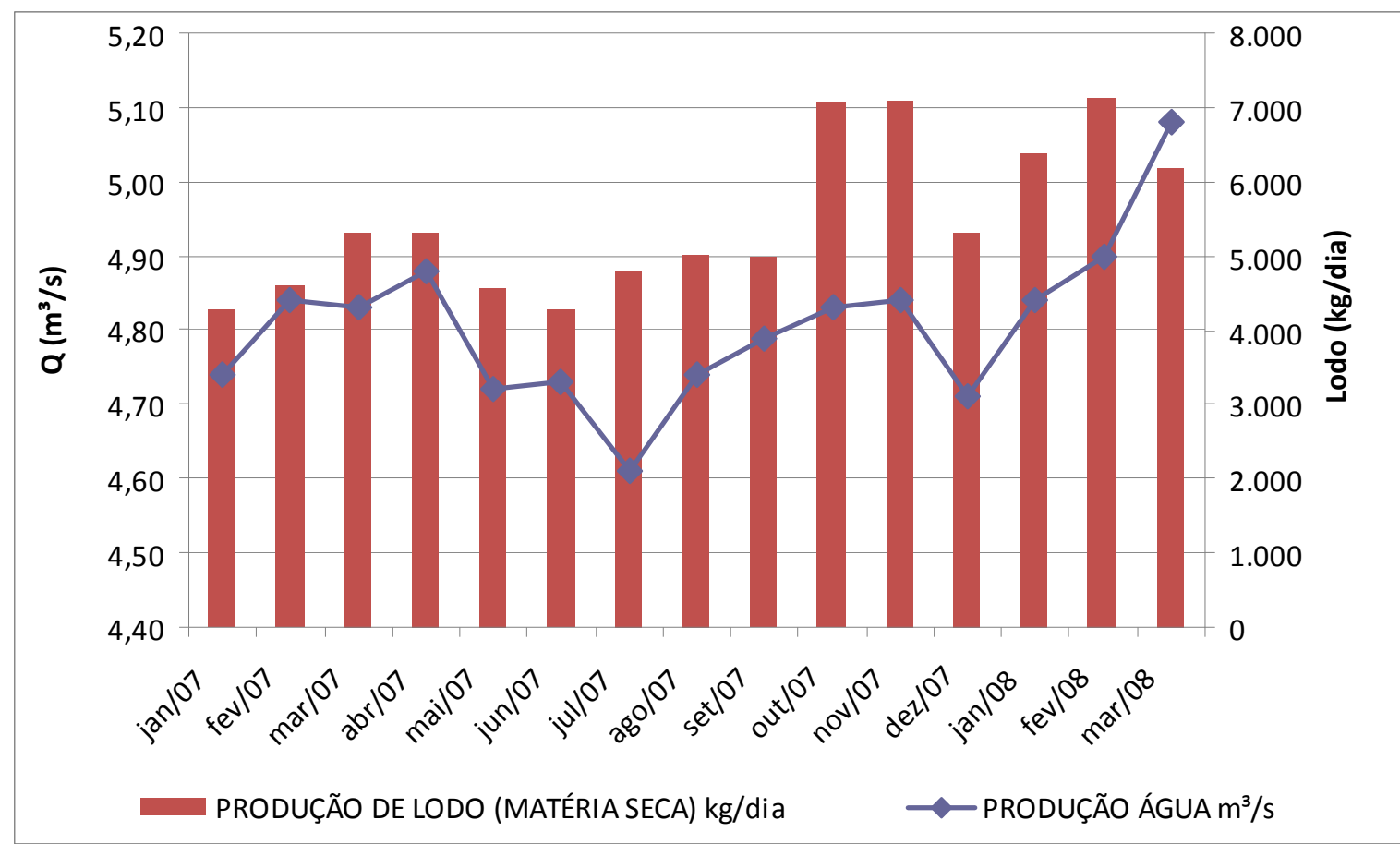

Figura 37 - Produção média diária por mês de lodo na ETA Rio Grande durante o período de estudo.

A partir dos dados de qualidade da água bruta, pode-se avaliar a produção de lodo também pela seguinte formulação, baseada no balanço de massa decorrente da aplicação de coagulantes e outros químicos, sendo bastante parecida com o proposto por Cornwell et al (1987) (FERREIRA FILHO, 2010):

$P=86,4 \cdot Q \cdot(k \cdot D+T+A)$

onde, $\mathrm{P}$ representa a produção de sólidos ( $\mathrm{kg}$ matéria seca/dia), Q é a vazão tratada na ETA ( $\left.\mathrm{m}^{3} / \mathrm{s}\right), \mathrm{k}$ a relação estequiométrica considerando a relação $1: 1$ entre SST e turbidez e função do coagulante dosado (igual a 0,535 no caso do sulfato de alumínio), D a dosagem de coagulante (ppm ou mg/L), T é a turbidez (UT), e A a dosagem de outros produtos químicos, como polímeros e CAP (mg/L).

Os resultados alcançados com esta estimativa são apresentados e comparados com os valores obtidos pela formulação da WRC na Tabela 4 abaixo: 
Tabela 4 - Comparação entre estimativas de produção de lodo pela formulação WRC e formulação estequiométrica.

\begin{tabular}{ccccc}
\hline Mês & $\begin{array}{c}\text { Estimativa WRC } \\
\text { (kg/dia) }\end{array}$ & $\begin{array}{c}\text { Estimativa } \\
\text { Estequiométrica } \\
\text { (kg/dia) }\end{array}$ & \multicolumn{2}{c}{$\begin{array}{c}\text { Diferencial } \\
\text { (kg/dia; \%) }\end{array}$} \\
\hline jan/07 & 4.269 & 4.725 & -456 & $-11 \%$ \\
fev/07 & 4.615 & 5.073 & -458 & $-10 \%$ \\
mar/07 & 5.300 & 5.355 & -55 & $-1 \%$ \\
abr/07 & 5.322 & 5.274 & 48 & $1 \%$ \\
mai/07 & 4.557 & 4.995 & -438 & $-10 \%$ \\
jun/07 & 4.270 & 4.659 & -389 & $-9 \%$ \\
jul/07 & 4.792 & 4.896 & -104 & $-2 \%$ \\
ago/07 & 5.030 & 4.959 & 70 & $1 \%$ \\
set/07 & 5.000 & 4.838 & 162 & $3 \%$ \\
out/07 & 7.060 & 6.108 & 952 & $13 \%$ \\
nov/07 & 7.087 & 5.994 & 1.092 & $15 \%$ \\
dez/07 & 5.310 & 4.669 & 641 & $12 \%$ \\
jan/08 & 6.365 & 4.936 & 1.428 & $22 \%$ \\
fev/08 & 7.114 & 5.316 & 1.798 & $25 \%$ \\
mar/08 & 6.173 & 5.423 & 750 & $12 \%$ \\
MÉDIA & $\mathbf{5 . 4 8 4}$ & $\mathbf{5 . 1 4 8}$ & $\mathbf{3 3 6}$ & $\mathbf{4} \%$ \\
\hline
\end{tabular}

Pode-se perceber que a diferença entre uma estimativa e outra, na média, é muito pequena (4\%), apresentando valores máximos da ordem de $20 \%$ de diferença, aceitável para este tipo de estimação.

Realizando agora um balanço de massa da vazão de lodo que chega à ETE $A B C$ e a vazão afluente a esta, pode-se determinar qual o acréscimo de sólidos decorrente do lançamento do lodo da ETA na ETE $(\Delta S$ indica o acréscimo de sólidos em mg/L; $\mathrm{S}_{\mathrm{L}}$, a concentração de sólidos no lodo; $\mathrm{Q}_{\mathrm{L}}$, a vazão de lodo da ETA; e $Q_{E T E}$ a vazão afluente à ETE):

$$
\Delta S=\frac{S_{L} \cdot Q_{L}}{Q_{L}+Q_{E T E}}
$$

Os resultados mês a mês podem ser vistos na Tabela 5 , considerando uma densidade de lodo de $1.000 \mathrm{~kg} / \mathrm{m}^{3}$ e um teor de sólidos no lodo de $4,0 \%$. Observa-se que a contribuição em termos de concentração de SST (mg/L) é cerca de $38 \mathrm{mg} / \mathrm{L}$. Tal observação será avaliada no próximo capítulo, onde se 
compara as variáveis monitoradas no esgoto bruto nos períodos antes e após o lançamento de lodo na ETE.

Tabela 5 - Concentração adicional de SST no esgoto bruto da ETE ABC, decorrente do lançamento do lodo da ETA Rio Grande.

\begin{tabular}{|c|c|c|c|c|c|c|c|c|}
\hline \multirow[b]{2}{*}{ Mês } & \multirow[b]{2}{*}{$\begin{array}{c}\text { Vazão } \\
\text { ETE ABC } \\
\text { (m³/dia) }\end{array}$} & \multicolumn{3}{|c|}{ ESTIMATIVA WRC } & \multicolumn{3}{|c|}{$\begin{array}{c}\text { ESTIMATIVA } \\
\text { ESTEQUIOMÉTRICA }\end{array}$} & \multirow[b]{2}{*}{$\begin{array}{l}\text { Contribuição } \\
\text { adicional } \\
\text { média de SST } \\
\text { (mg/L) }\end{array}$} \\
\hline & & $\begin{array}{c}\text { Produção } \\
\text { de lodo } \\
\text { (kg/dia) }\end{array}$ & $\begin{array}{l}\text { Vazão } \\
\text { líquida de } \\
\text { lodo } \\
\text { (m³/dia) }\end{array}$ & $\begin{array}{c}\Delta S S T \\
\text { esgoto } \\
\text { bruto } \\
\text { ETE ABC } \\
\text { (mg/L) }\end{array}$ & $\begin{array}{l}\text { Produção } \\
\text { de lodo } \\
\text { (kg/dia) }\end{array}$ & $\begin{array}{l}\text { Vazão } \\
\text { líquida de } \\
\text { lodo } \\
\text { (m³/dia) }\end{array}$ & $\begin{array}{c}\Delta S S T \\
\text { esgoto } \\
\text { bruto ETE } \\
\text { ABC } \\
(\mathrm{mg} / \mathrm{L}) \\
\end{array}$ & \\
\hline jan/07 & 129.600 & 4.269 & 107 & 33 & 4.725 & 118 & 36 & 35 \\
\hline fev/07 & 134.266 & 4.615 & 115 & 34 & 5.073 & 127 & 38 & 36 \\
\hline $\mathrm{mar} / 07$ & 136.080 & 5.300 & 133 & 39 & 5.355 & 134 & 39 & 39 \\
\hline$a b r / 07$ & 135.043 & 5.322 & 133 & 39 & 5.274 & 132 & 39 & 39 \\
\hline mai/07 & 129.600 & 4.557 & 114 & 35 & 4.995 & 125 & 39 & 37 \\
\hline jun/07 & 130.810 & 4.270 & 107 & 33 & 4.659 & 116 & 36 & 34 \\
\hline jul/07 & 148.781 & 4.792 & 120 & 32 & 4.896 & 122 & 33 & 33 \\
\hline ago/07 & 125.885 & 5.030 & 126 & 40 & 4.959 & 124 & 39 & 40 \\
\hline set/07 & 127.267 & 5.000 & 125 & 39 & 4.838 & 121 & 38 & 39 \\
\hline out/07 & 142.560 & 7.060 & 176 & 49 & 6.108 & 153 & 43 & 46 \\
\hline nov/07 & 125.539 & 7.087 & 177 & 56 & 5.994 & 150 & 48 & 52 \\
\hline $\mathrm{dez} / 07$ & 146.275 & 5.310 & 133 & 36 & 4.669 & 117 & 32 & 34 \\
\hline jan/08 & 177.466 & 6.365 & 159 & 36 & 4.936 & 123 & 28 & 32 \\
\hline fev/08 & 171.504 & 7.114 & 178 & 41 & 5.316 & 133 & 31 & 36 \\
\hline $\mathrm{mar} / 08$ & 152.150 & 6.173 & 154 & 41 & 5.423 & 136 & 36 & 38 \\
\hline
\end{tabular}

\subsection{Esgoto afluente à $E T E A B C$ e eficiência global do tratamento}

As variáveis monitoradas neste estudo no esgoto afluente são as seguintes: vazão $\left(\mathrm{m}^{3} / \mathrm{s}\right)$, DBO, DQO, SST, SSV, SSVISST, NTK, nitrogênio amoniacal, fósforo total e ferro total (concentrações em $\mathrm{mg} / \mathrm{L}$ ). As mesmas variáveis são também observadas no efluente final, determinando-se, assim, a eficiência global do tratamento na ETE e se este atende às exigências das legislações ambientais aplicáveis.

As tabelas a seguir (Tabela 6 e Tabela 7) apresentam os valores médios, medianos, de desvio-padrão, máximo, mínimo e do coeficiente de variação destas variáveis para os períodos controle (anos de 2005 e 2006, sem o lodo da ETA) e com lodo (2007 em diante), respectivamente: 
Tabela 6 - Variáveis monitoradas no esgoto bruto afluente e efluente final da ETE ABC - período controle.

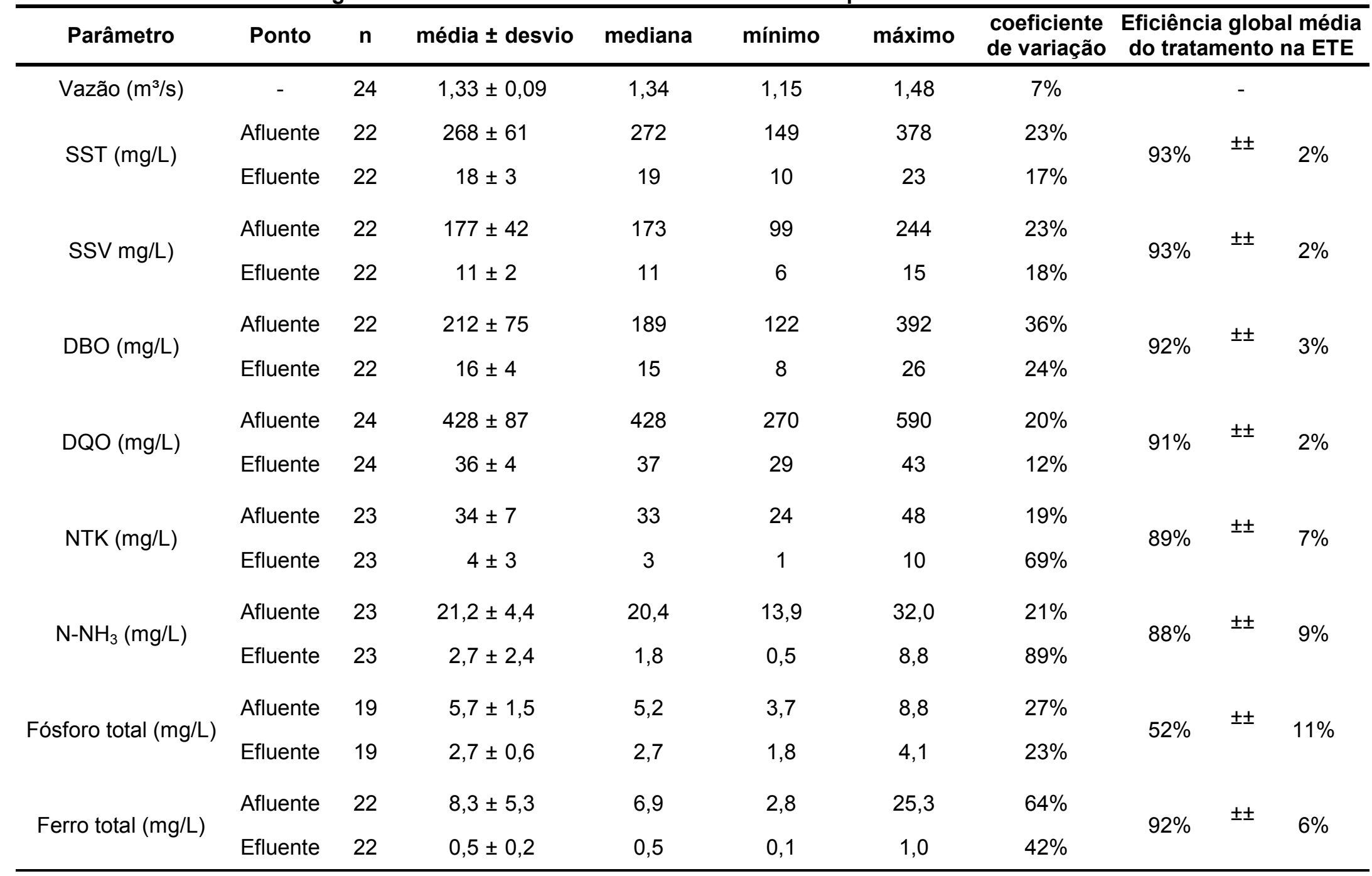


Tabela 7 - Variáveis monitoradas no esgoto bruto afluente e efluente final da ETE ABC - período pós-lançamento do lodo da ETA na ETE.

\begin{tabular}{|c|c|c|c|c|c|c|c|c|c|c|}
\hline Parâmetro & Ponto & $\mathbf{n}$ & média \pm desvio & mediana & mínimo & máximo & $\begin{array}{l}\text { coeficiente } \\
\text { de variação }\end{array}$ & \multicolumn{3}{|c|}{$\begin{array}{l}\text { Eficiência global média } \\
\text { do tratamento na ETE }\end{array}$} \\
\hline Vazão (m³/s) & - & 14 & $1,60 \pm 0,15$ & 1,56 & 1,45 & 1,99 & $9 \%$ & & - & \\
\hline \multirow{2}{*}{ SST (mg/L) } & Afluente & 15 & $342 \pm 77$ & 342 & 228 & 474 & $23 \%$ & \multirow{2}{*}{$96 \%$} & \multirow{2}{*}{ \pm} & \multirow{2}{*}{$1 \%$} \\
\hline & Efluente & 15 & $12 \pm 3$ & 12 & 7 & 18 & $26 \%$ & & & \\
\hline \multirow{2}{*}{ SSV mg/L) } & Afluente & 15 & $208 \pm 50$ & 206 & 124 & 286 & $24 \%$ & \multirow{2}{*}{$96 \%$} & \multirow{2}{*}{ \pm} & \multirow{2}{*}{$1 \%$} \\
\hline & Efluente & 15 & $7 \pm 2$ & 7 & 4 & 10 & $22 \%$ & & & \\
\hline \multirow{2}{*}{ DBO (mg/L) } & Afluente & 15 & $293 \pm 108$ & 298 & 146 & 495 & $37 \%$ & \multirow{2}{*}{$94 \%$} & \multirow{2}{*}{ \pm} & \multirow{2}{*}{$3 \%$} \\
\hline & Efluente & 15 & $16 \pm 5$ & 16 & 8 & 23 & $29 \%$ & & & \\
\hline \multirow{2}{*}{$\mathrm{DQO}(\mathrm{mg} / \mathrm{L})$} & Afluente & 13 & $490 \pm 133$ & 487 & 314 & 689 & $27 \%$ & \multirow{2}{*}{$93 \%$} & \multirow{2}{*}{ \pm} & \multirow{2}{*}{$1 \%$} \\
\hline & Efluente & 13 & $35 \pm 6$ & 34 & 24 & 46 & $17 \%$ & & & \\
\hline \multirow{2}{*}{ NTK (mg/L) } & Afluente & 11 & $37 \pm 5$ & 34 & 31 & 46 & $15 \%$ & \multirow{2}{*}{$85 \%$} & \multirow{2}{*}{ \pm} & \multirow{2}{*}{$9 \%$} \\
\hline & Efluente & 11 & $5 \pm 3$ & 4 & 2 & 11 & $62 \%$ & & & \\
\hline \multirow{2}{*}{$\mathrm{N}-\mathrm{NH}_{3}(\mathrm{mg} / \mathrm{L})$} & Afluente & 15 & $22,3 \pm 3,1$ & 22,0 & 17,8 & 27,8 & $14 \%$ & \multirow{2}{*}{$81 \%$} & \multirow{2}{*}{ \pm} & \multirow{2}{*}{$13 \%$} \\
\hline & Efluente & 15 & $4,2 \pm 2,9$ & 3,0 & 0,6 & 9,1 & $69 \%$ & & & \\
\hline \multirow{2}{*}{ Fósforo total (mg/L) } & Afluente & 15 & $8,4 \pm 4,5$ & 6,9 & 3,0 & 17,8 & $54 \%$ & \multirow{2}{*}{$88 \%$} & \multirow{2}{*}{ \pm} & \multirow{2}{*}{$15 \%$} \\
\hline & Efluente & 15 & $0,7 \pm 0,7$ & 0,4 & 0,2 & 2,3 & $99 \%$ & & & \\
\hline \multirow{2}{*}{ Ferro total $(\mathrm{mg} / \mathrm{L})$} & Afluente & 10 & $41,2 \pm 23,9$ & 34,4 & 5,4 & 76,5 & $58 \%$ & \multirow{2}{*}{$96 \%$} & \multirow{2}{*}{ \pm} & \multirow{2}{*}{$6 \%$} \\
\hline & Efluente & 10 & $0,9 \pm 0,6$ & 0,6 & 0,4 & 2,1 & $73 \%$ & & & \\
\hline
\end{tabular}




\subsubsection{Vazão}

Observa-se que a vazão média no segundo período é maior que no primeiro, fato este esperado, uma vez que há a tendência de aumento de vazão conforme novas ligações à rede coletora são instaladas. A variação observada em cada período se deve à existência de sazonalidade nos valores de vazão: maior vazão no período chuvoso (geralmente, de outubro a março) e menor na época de estiagem (abril a setembro).

Analisando a série histórica de vazões (Figura 38), fica evidente este aumento gradual, através da regressão linear com inclinação positiva (em torno de 13,4 L/s por mês, correspondente a um valor aproximado de mais 6.000 habitantes ligados à rede coletora por mês, seja por ligação direta à rede ou por interceptação de novos coletores-tronco):

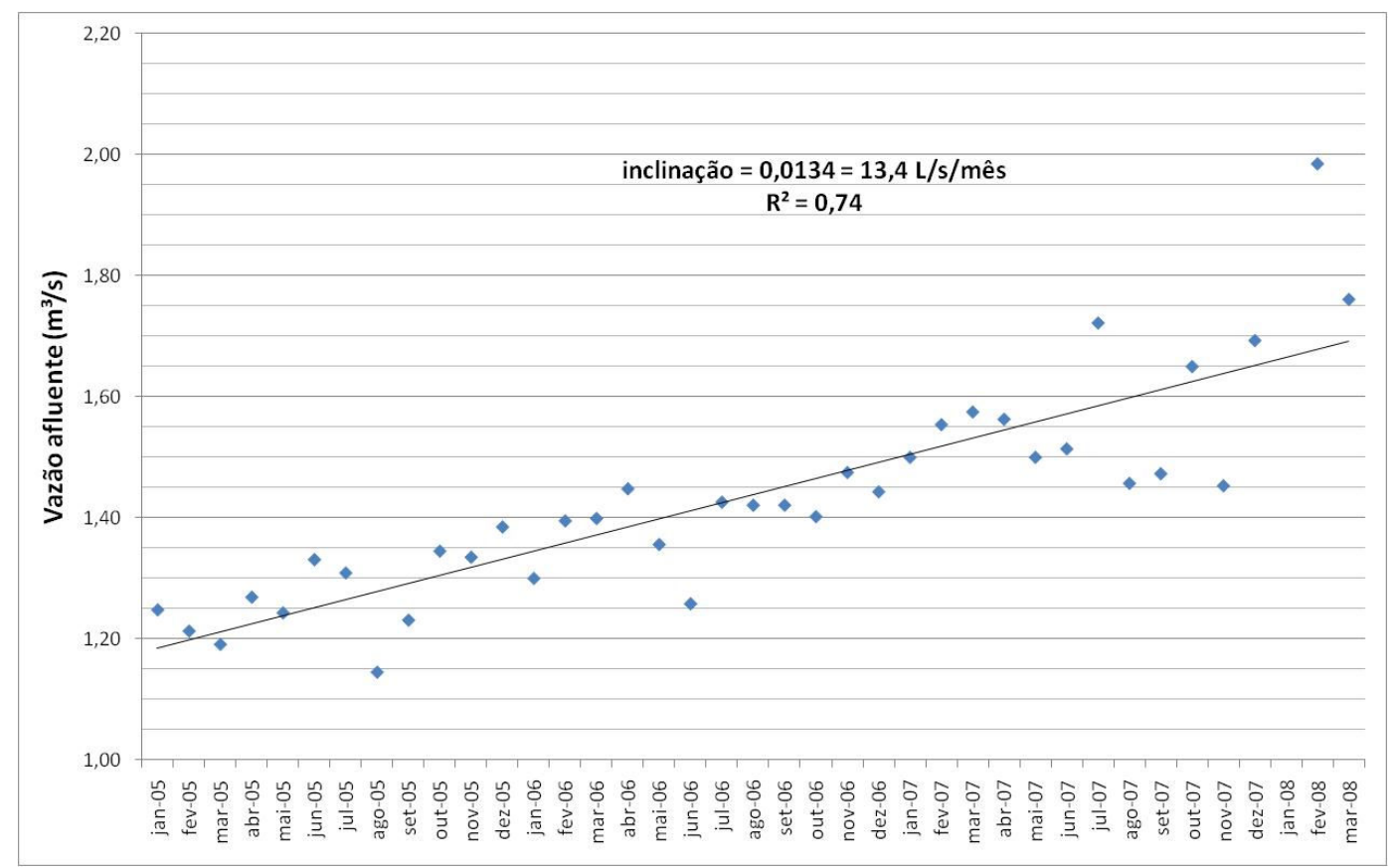

Figura 38 - Vazão média afluente à ETE ABC.

\subsubsection{Matéria Orgânica: DBO e DQO}

Pelos valores apresentados nas Tabela 6 e Tabela 7, a concentração de matéria orgânica no esgoto afluente sofreu um acréscimo quando se compara o período antes do lançamento do lodo com o de depois.

Para a DBO afluente, o aumento médio observado foi de $80 \mathrm{mg} / \mathrm{L}$. Porém, como se observa na série histórica uma diferença significativa entre os dois anos do período 
controle, onde 2006 possui valores de DBO afluente muito menores, convém comparar utilizando apenas o ano de 2005 deste período. Neste caso, apresentado no box-plot da Figura 39, o aumento de DBO foi da ordem de $40 \mathrm{mg} / \mathrm{L}$. Entretanto, quando se leva em consideração a variabilidade dos dados (distância interquartil), percebe-se que este aumento de concentração foi ínfimo.

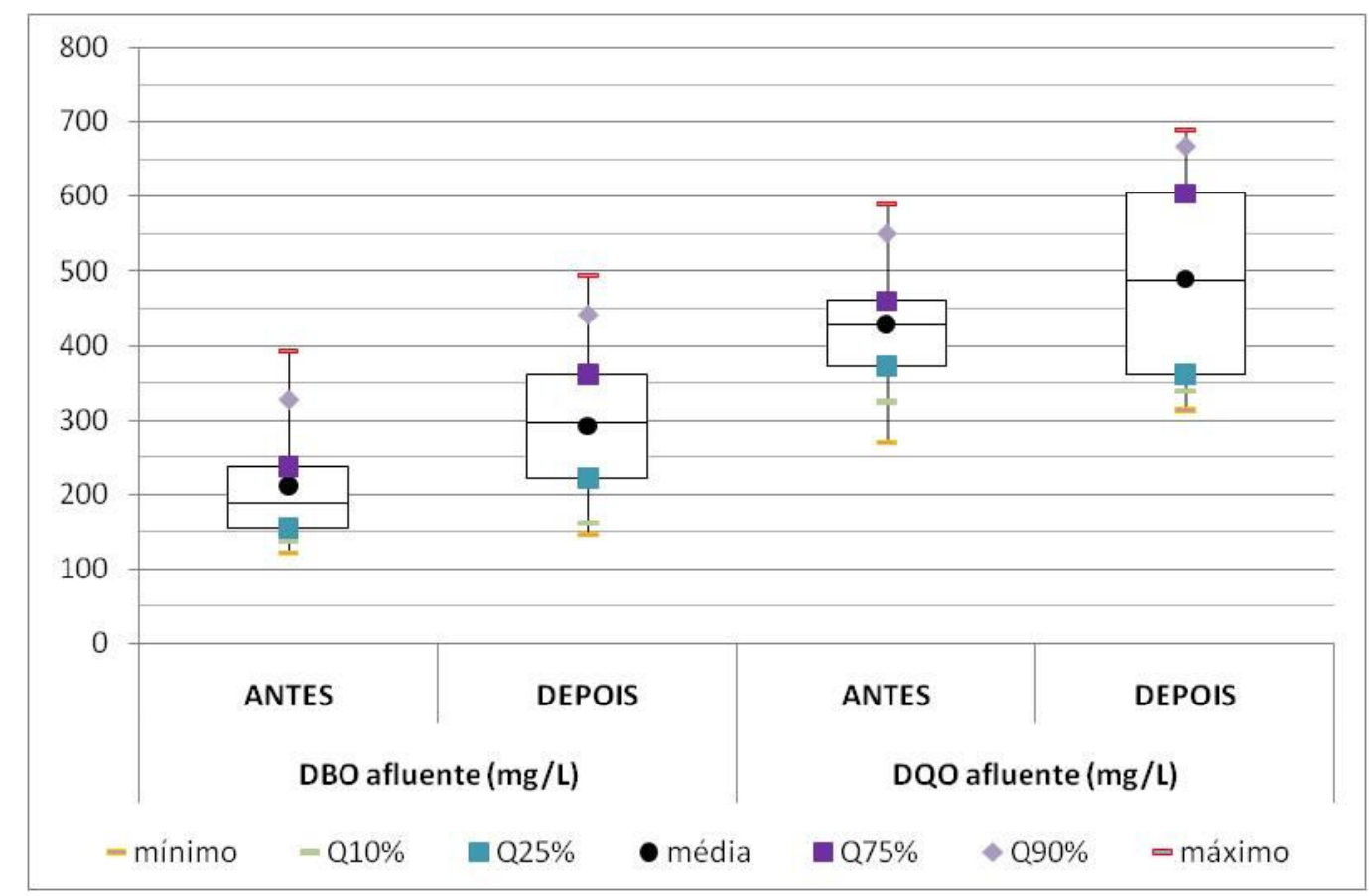

Figura 39 - DBO e DQO afluente (mg/L).

No caso da DQO afluente, esta apresenta valores menos discrepantes entre os anos de 2005 e 2006, de modo que, comparando-se os períodos sem e com lançamento do lodo da ETA, o aumento observado foi de $94 \mathrm{mg} / \mathrm{L}$ na média (22\%). Isto pode ser observado no diagrama box-plot acima, onde se percebe um aumento na variabilidade dos dados no período com o lançamento do lodo na ETE.

Tal aumento de concentração de matéria orgânica no esgoto afluente à ETE justifica-se em parte pelo fato de, mesmo o lodo sendo predominantemente constituído por compostos inorgânicos (porém possivelmente oxidáveis pelo dicromato, daí o aumento de DQO), há ainda certa parcela das impurezas retiradas no tratamento da água que possui composição orgânica, uma vez que se trata de manancial tipo lêntico, onde frequentemente ocorre o acúmulo de algas devido ao fenômeno de eutrofização. 
Além disso, como se observou aumento de vazão decorrente de novas ligações à rede coletora, uma parte deste aumento de carga orgânica pode ser atribuído também à contribuição doméstica.

Em relação ao efluente final da ETE, no período controle houve um valor médio de $16 \mathrm{mg} / \mathrm{L}$ de $\mathrm{DBO}$ e $36 \mathrm{mg} / \mathrm{L}$ de DQO, correspondendo a uma eficiência global de tratamento de $92 \%$ e $91 \%$, respectivamente. No período com lodo, as concentrações observadas são na prática as mesmas observadas no controle $(16 \mathrm{mg} / \mathrm{L}$ de DBO e $35 \mathrm{mg} / \mathrm{L}$ de DQO), indicando que, mesmo com um pequeno aumento na eficiência de remoção total da ETE em termos de matéria orgânica - em $3 \%$ e $2 \%$, respectivamente -, não houve qualquer melhoria global na qualidade do efluente final. Continua-se, então, ainda de acordo com a legislação vigente no período (resolução CONAMA nº. 357/05).

Os diagramas box-plot para DBO e DQO no efluente final, bem como da eficiência de remoção global destas variáveis nos períodos controle e com lodo são apresentados nos gráficos abaixo (Figura 40 e Figura 41):

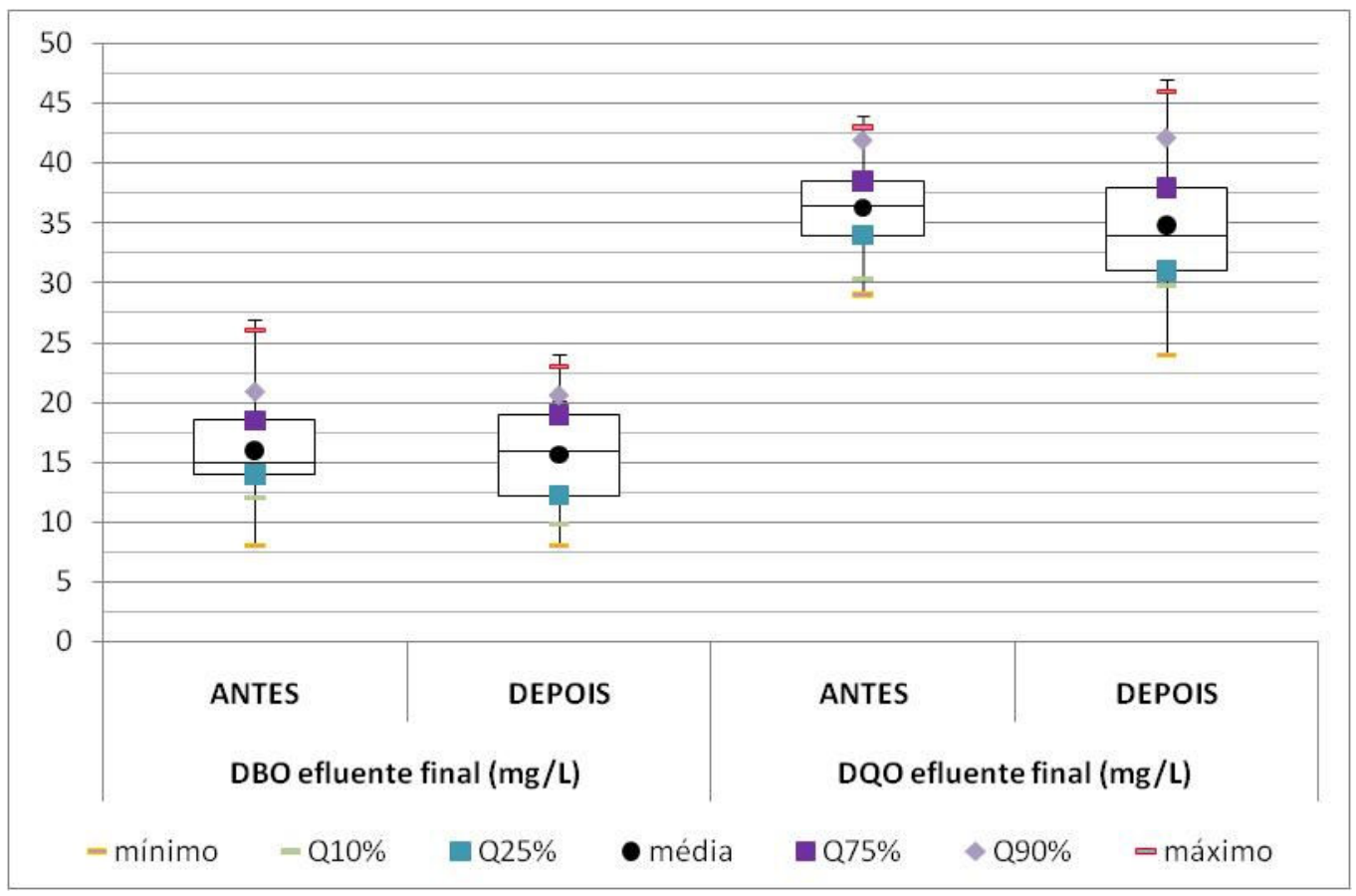

Figura 40 - DBO e DQO efluente final (mg/L). 


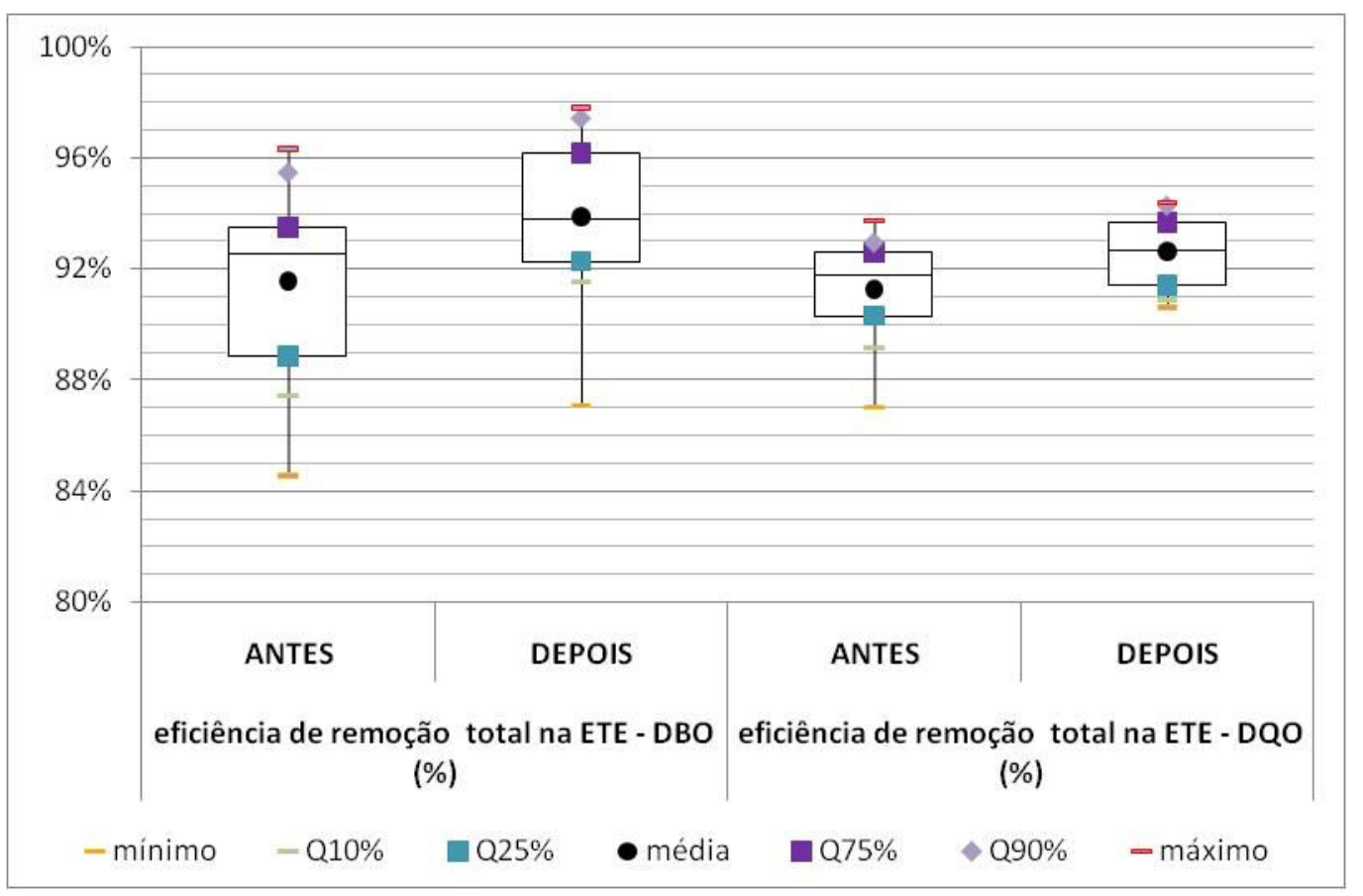

Figura 41 - DBO e DQO: Eficiência de remoção total na ETE ABC (\%).

A Figura 42 abaixo apresenta a série histórica dos valores de DBO e DQO observados tanto no esgoto afluente quanto no efluente final, onde se observa certa sazonalidade nas concentrações, envolvendo período chuvoso e de estiagem. Além disso, observa-se a manutenção da qualidade do efluente final, mesmo após a adição de lodo da ETA na ETE:

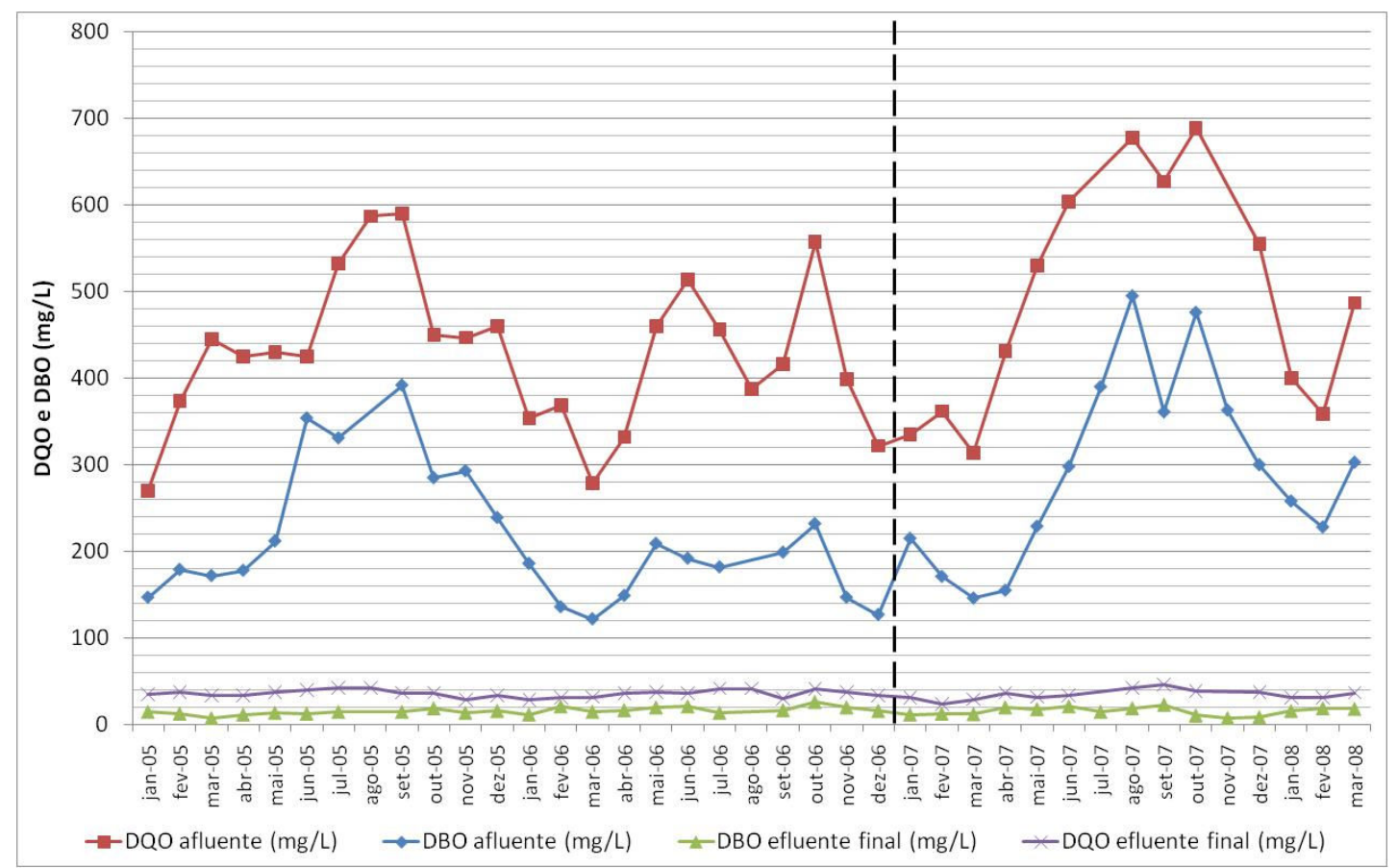

Figura 42 - Série de valores - DBO e DQO no esgoto afluente e no efluente final da ETE ABC. 


\subsubsection{Sólidos}

Como observado nas Tabela 6 e Tabela 7, a concentração de sólidos afluente é maior no período onde há lançamento do lodo da ETA na ETE. Isto ocorre tanto para SST quanto para SSV, ocorrendo um aumento médio de $28 \%$ e $18 \%$, respectivamente.

Para uma melhor visualização deste fenômeno, vale observar os diagramas box-plot para estas duas variáveis, bem como para a relação SSVISST, a qual sofreu uma queda no período pós-lançamento do lodo (Figura 43 e Figura 44).

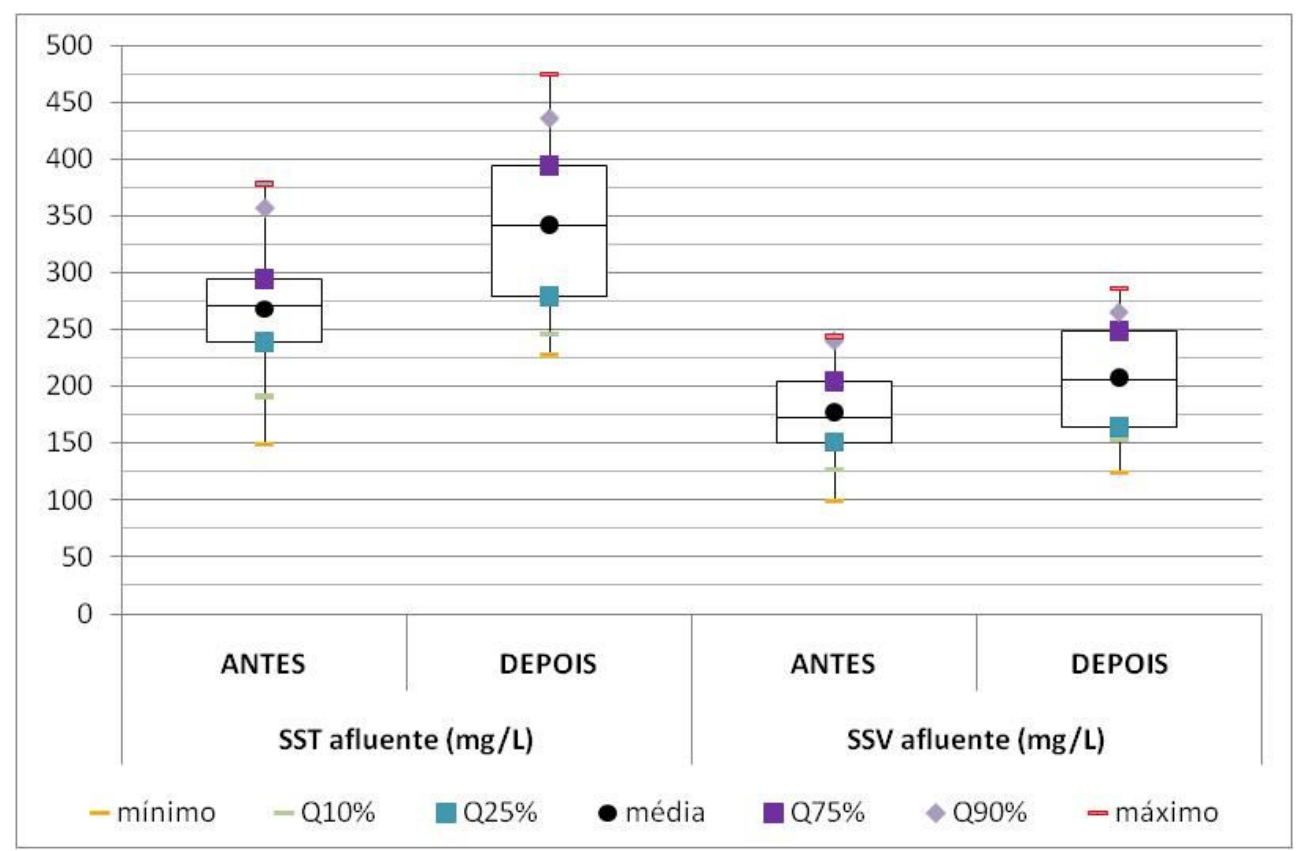

Figura 43 - SSV e SST afluente (mg/L). 


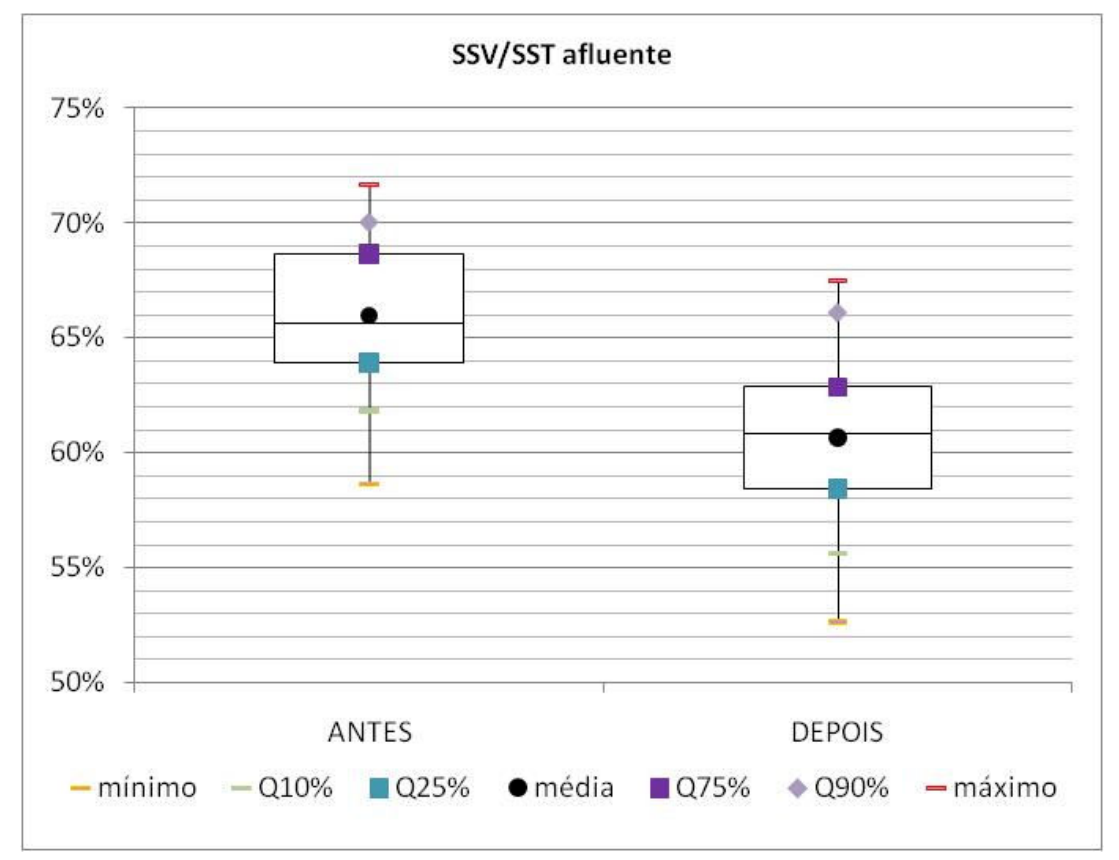

Figura 44 - Relação SSVISST no esgoto afluente (\%).

Pode-se observar que os dados, mesmo apresentando grande variação, são bem distribuídos em torno da média, sendo esta bastante próxima da mediana, ocorrendo também intervalos interquartis moderados, mas que aumentam no período com lodo da ETA, indicando maior variabilidade dos dados neste período.

O maior aumento de sólidos totais afluentes em relação aos voláteis, com a consequente diminuição da relação SSVISST em 8\% (de 66\% para 61\%), se deve ao fato da composição do lodo da ETA ser predominantemente constituída de material inorgânico, advindo das impurezas da água bruta e dos produtos químicos adicionados ao longo do tratamento (coagulante e polímero). Isto também foi observado por Asada (2007).

Percebe-se que o aumento na concentração de SST afluente é maior que o esperado: $74 \mathrm{mg} / \mathrm{L}$, contra os $38 \mathrm{mg} / \mathrm{L}$ estimados no capítulo anterior (Tabela 5). Pode-se justificar este acréscimo de praticamente o dobro da concentração por:

- uma pequena parte à contribuição das novas ligações à rede coletora neste período, como no caso da vazão afluente;

- o fato de o envio de lodo, mesmo sendo contínuo, varia em termos de quantidade ao longo do dia, dependendo das diversas variáveis já relacionadas (vazão, dosagem de produtos químicos e qualidade da água bruta), as quais não são constantes ao longo do dia; 
- $\quad$ por fim, a hipótese de relação 1:1 entre SST e turbidez pode estar falha no caso da ETA Rio Grande.

No efluente final, observa-se uma ligeira melhoria na sua qualidade em termos de SST e SSV após a chegada do lodo da ETA na ETE: a concentração média de SST final passou de $18 \mathrm{mg} / \mathrm{L}$ para $12 \mathrm{mg} / \mathrm{L}$ (redução de 31\%), enquanto para o SSV diminui-se de $11 \mathrm{mg} / \mathrm{L}$ para $7 \mathrm{mg} / \mathrm{L}(35 \%)$.

Em termos de eficiência de remoção global do processo de tratamento da ETE ABC, observou-se, também, uma pequena melhoria, sendo esta em mais $3 \%$ tanto para a remoção de SST quanto de SSV (de 93\% para 96\%). Sendo assim, a ETE continuou a atender os padrões de lançamento estabelecidos mesmo com a adição do lodo da ETA no processo.

As Figura 45 e Figura 46 apresentam, respectivamente, os diagramas box-plot para SST e SSV no efluente final e para a eficiência de remoção global na ETE das duas variáveis. A Figura 47 apresenta a série histórica de sólidos afluente e efluente, assim como a relação SSVISST no afluente.

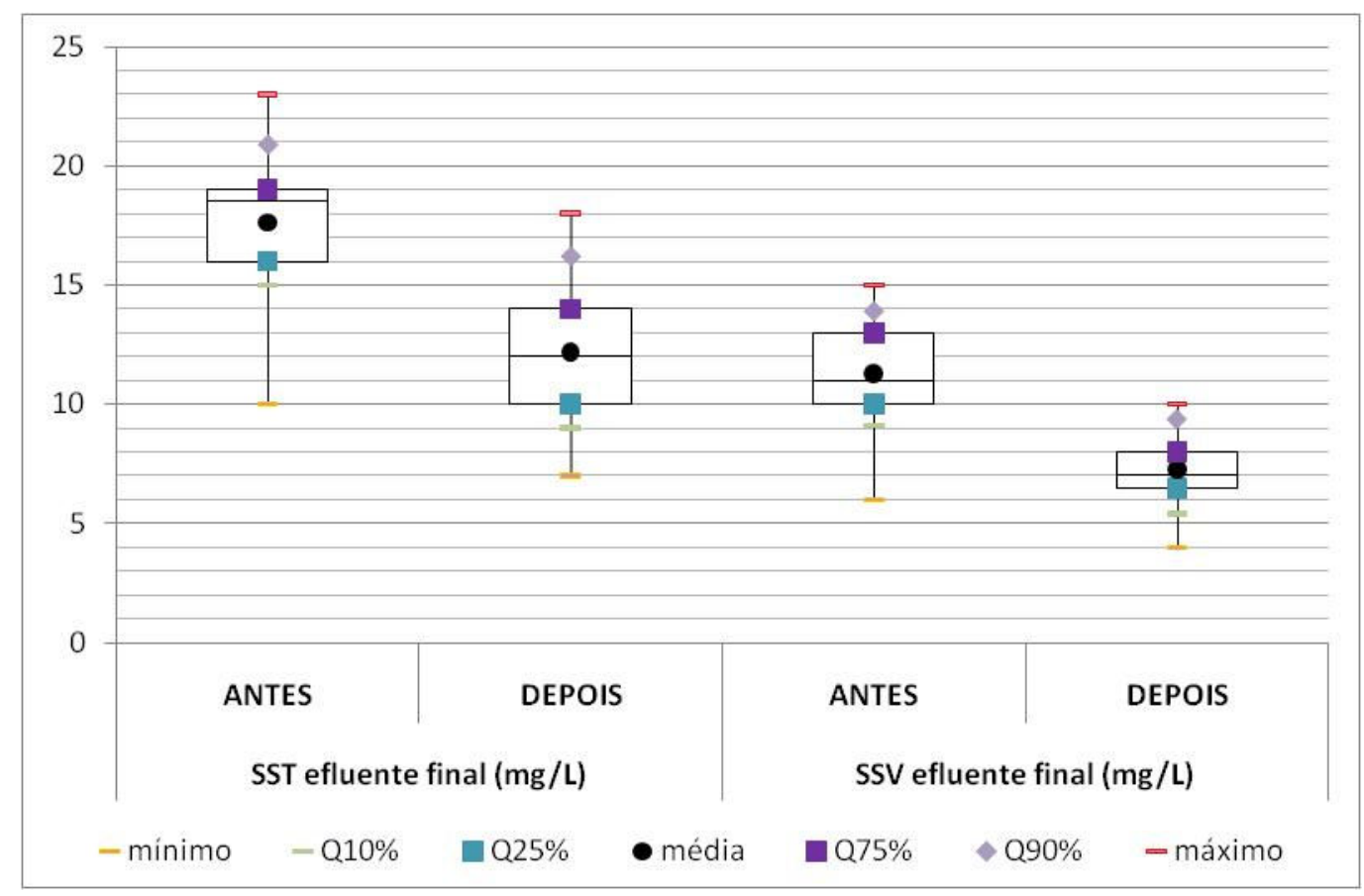

Figura 45 - SST e SSV no efluente final. 


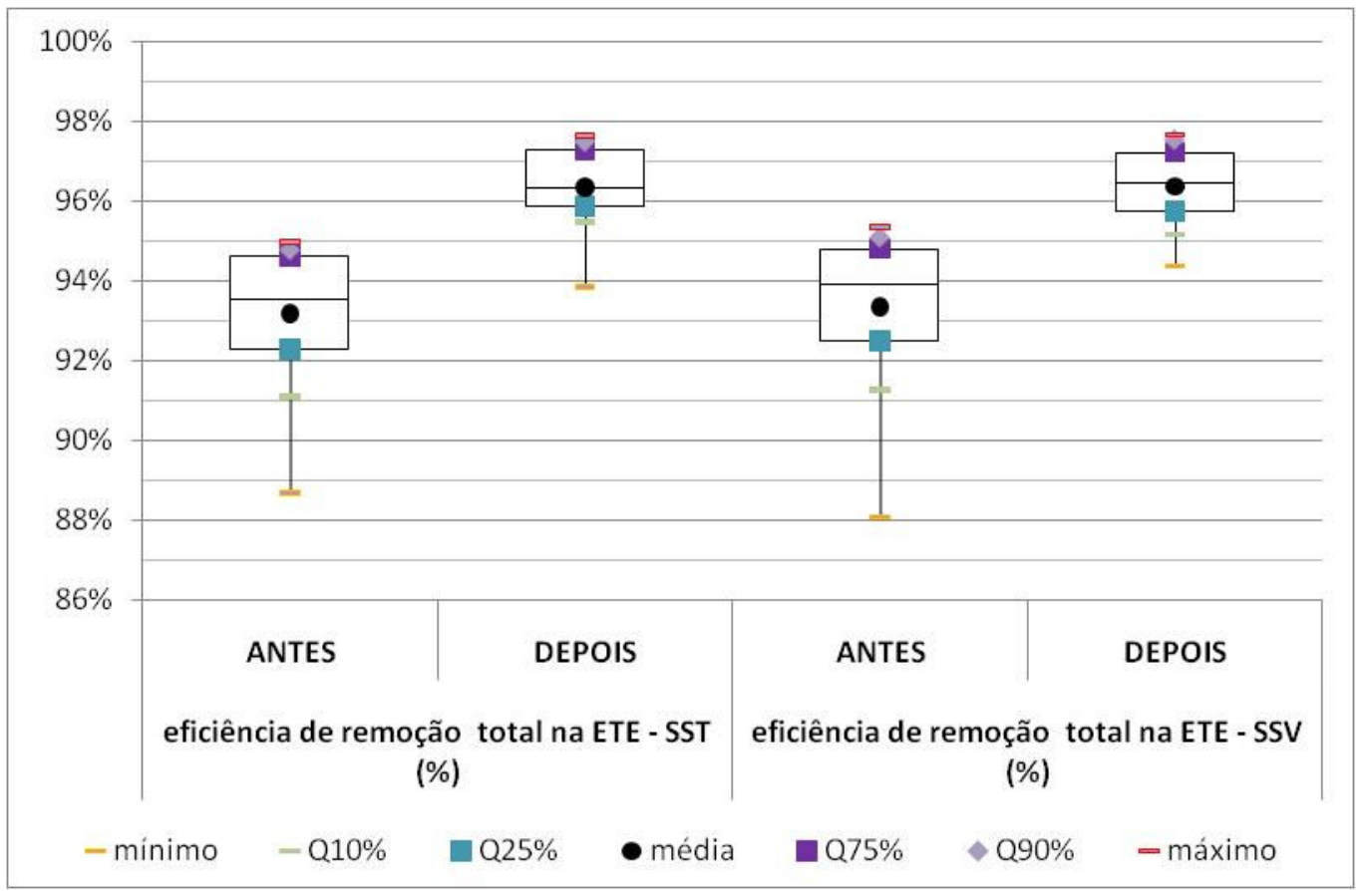

Figura 46 - SST e SSV: Eficiência de remoção total na ETE ABC (\%).

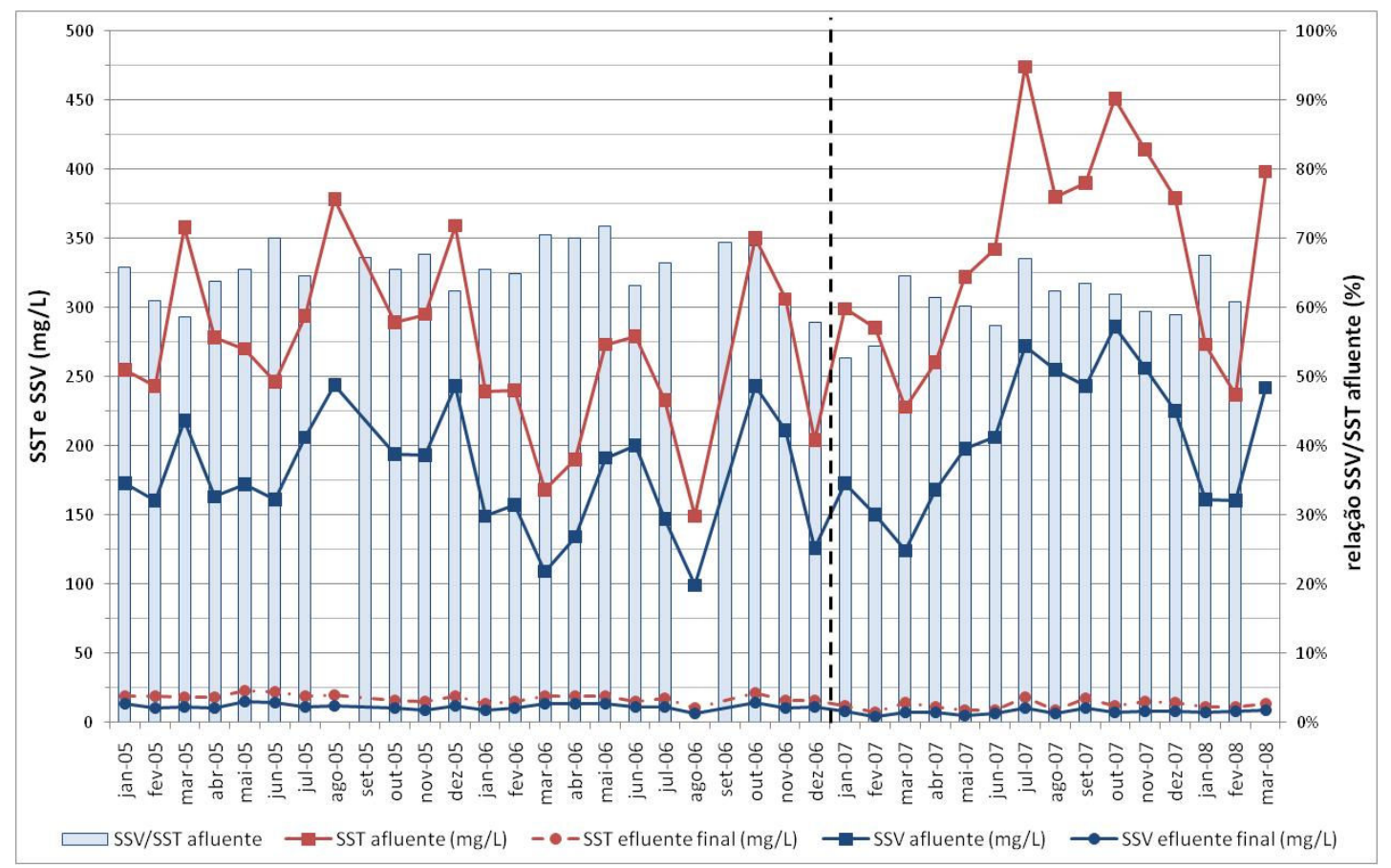

Figura 47 - Série de valores - SST, SSV e relação SSV/SST no esgoto afluente e efluente final da ETE ABC.

\subsubsection{Nitrogênio}

As Tabela 6 e Tabela 7 mostram que as concentrações afluentes tanto de nitrogênio total quanto de nitrogênio amoniacal permaneceram praticamente inalteradas, mesmo após a adição do lodo, da mesma forma que ocorreu em Asada (2007). 
No caso do nitrogênio total, o acréscimo observado foi de $2,4 \mathrm{mg} / \mathrm{L}$ (7\%). Para o nitrogênio amoniacal, este aumento foi de apenas $1,1 \mathrm{mg} / \mathrm{L}(5 \%)$.

A Figura 48 abaixo apresenta os diagramas box-plot para estas variáveis. Neles é nítida que a variabilidade dos dados também não se altera no período com lodo.

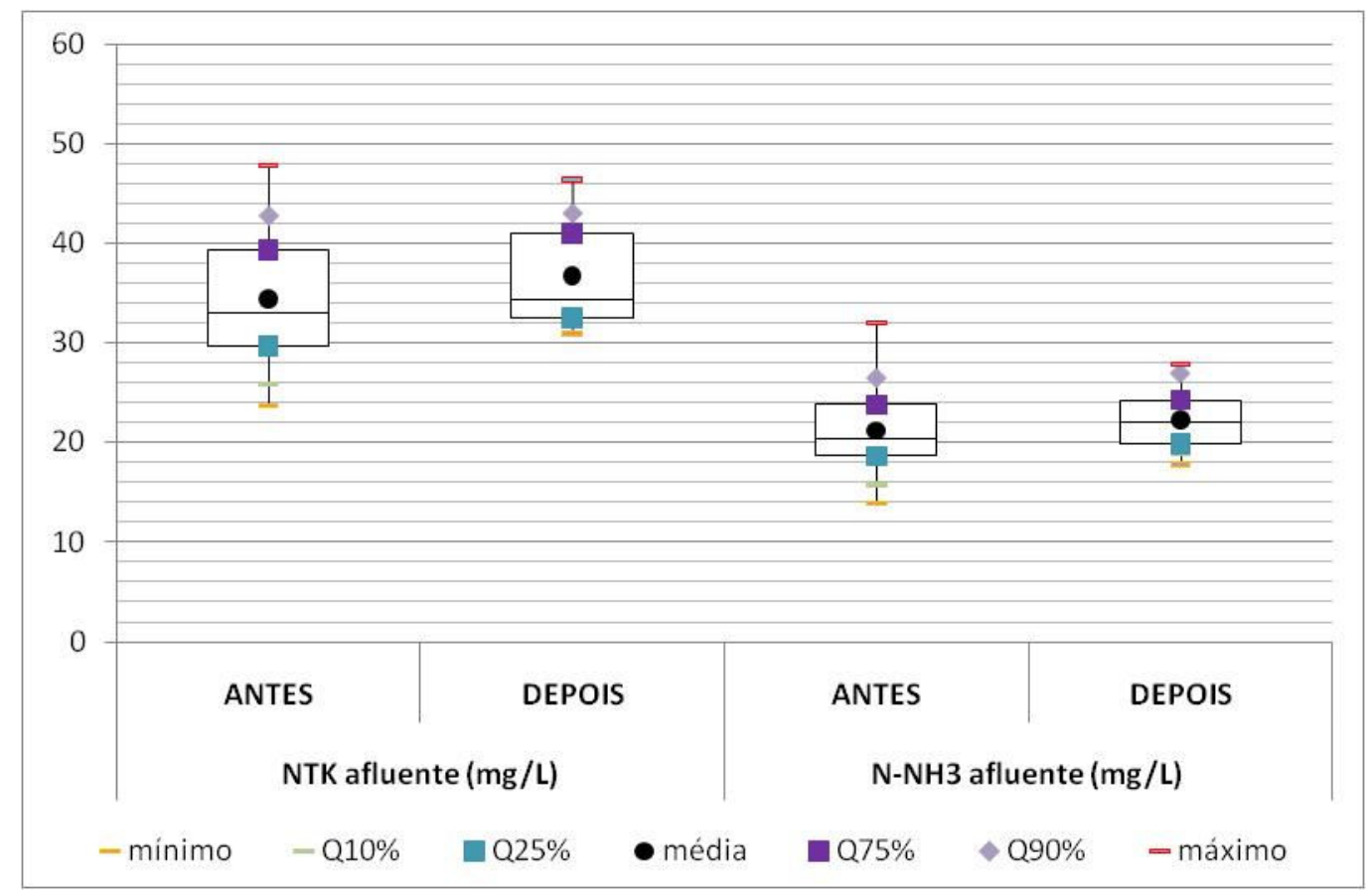

Figura 48 - NTK e Nitrogênio Amoniacal afluente (mg/L).

Em relação ao efluente final da ETE, percebe-se uma ligeira piora na qualidade, não crítica, do efluente no período com lançamento do lodo, com aumento na concentração final de nitrogênio amoniacal e total, indicando menor eficiência de remoção. Para o nitrogênio total final, o aumento de concentração foi de $45 \%$ em média - de 3,7 mg/L para 5,3 mg/L -, enquanto que para o nitrogênio amoniacal foi de $53 \%$ (2,7 mg/L para $4,2 \mathrm{mg} / \mathrm{L})$.

Porém, mesmo com esta piora, os valores efluentes finais após o lançamento do lodo não são críticos, uma vez que a $E T E ~ A B C$ não foi projetada visando a nitrificação e a desnitrificação, de modo que as variáveis nitrogenadas não são padrão de emissão.

As Figura 49 e Figura 50 abaixo apresentam, respectivamente, os diagramas bloxplot para nitrogênio total e amoniacal no efluente final, e a eficiência de remoção global destas variáveis pelo tratamento na ETE ABC. A Figura 51 mostra a série histórica de valores para estas variáveis: 


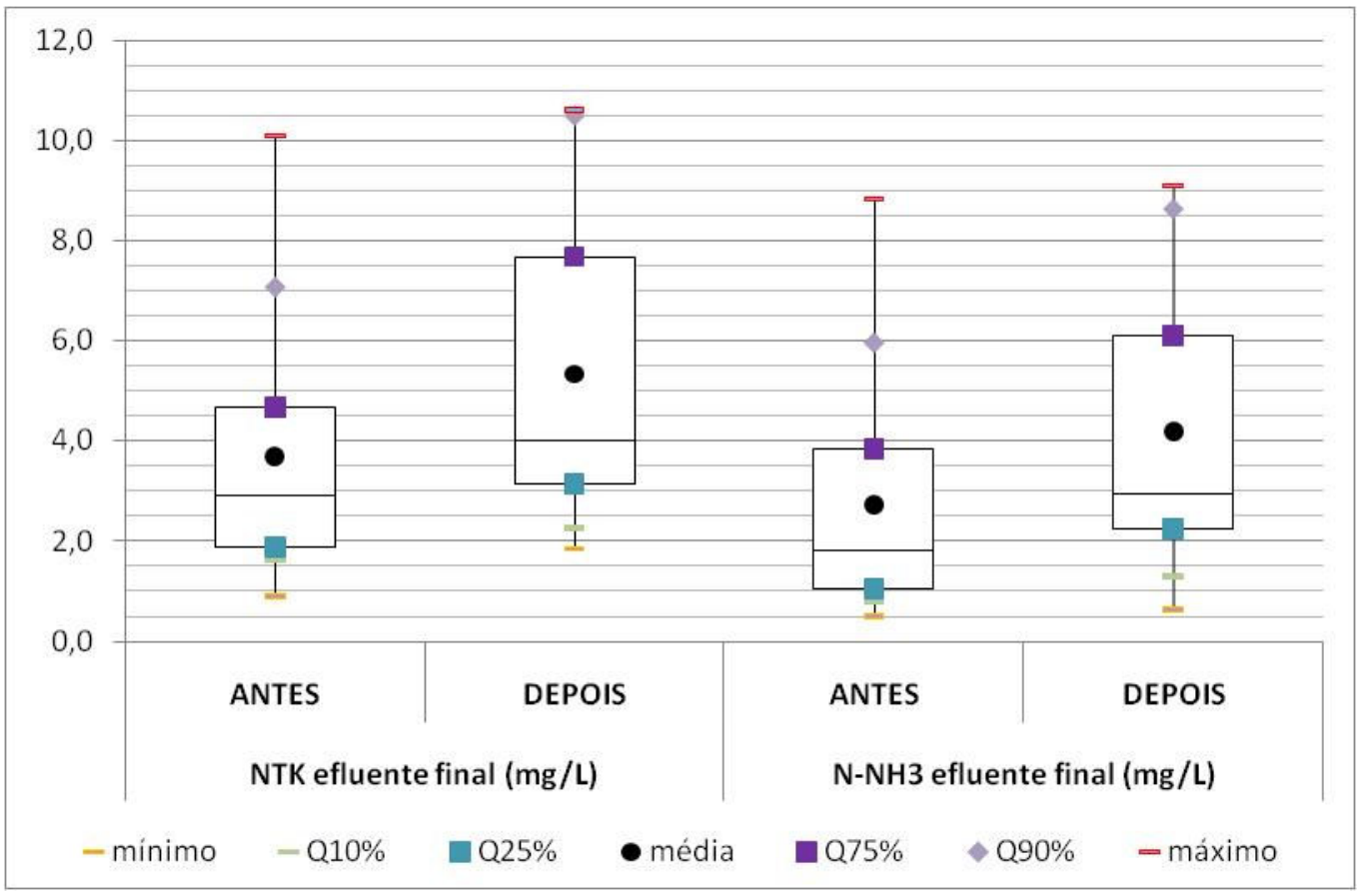

Figura 49 - NTK e Nitrogênio Amoniacal efluente final (mg/L).

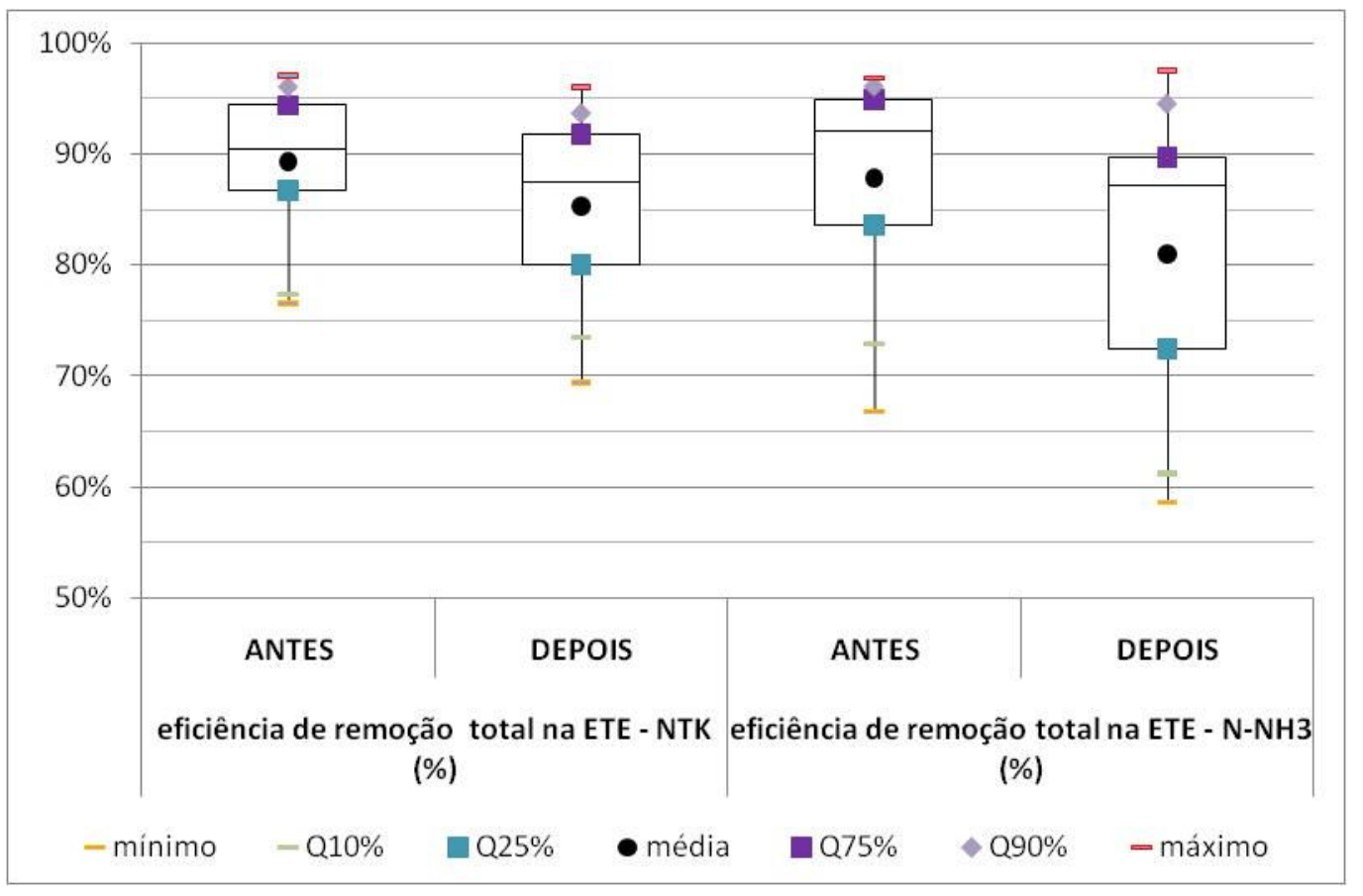

Figura 50 - $\mathrm{NTK}$ e N-NH : Eficiência de remoção total na ETE ABC (\%). 


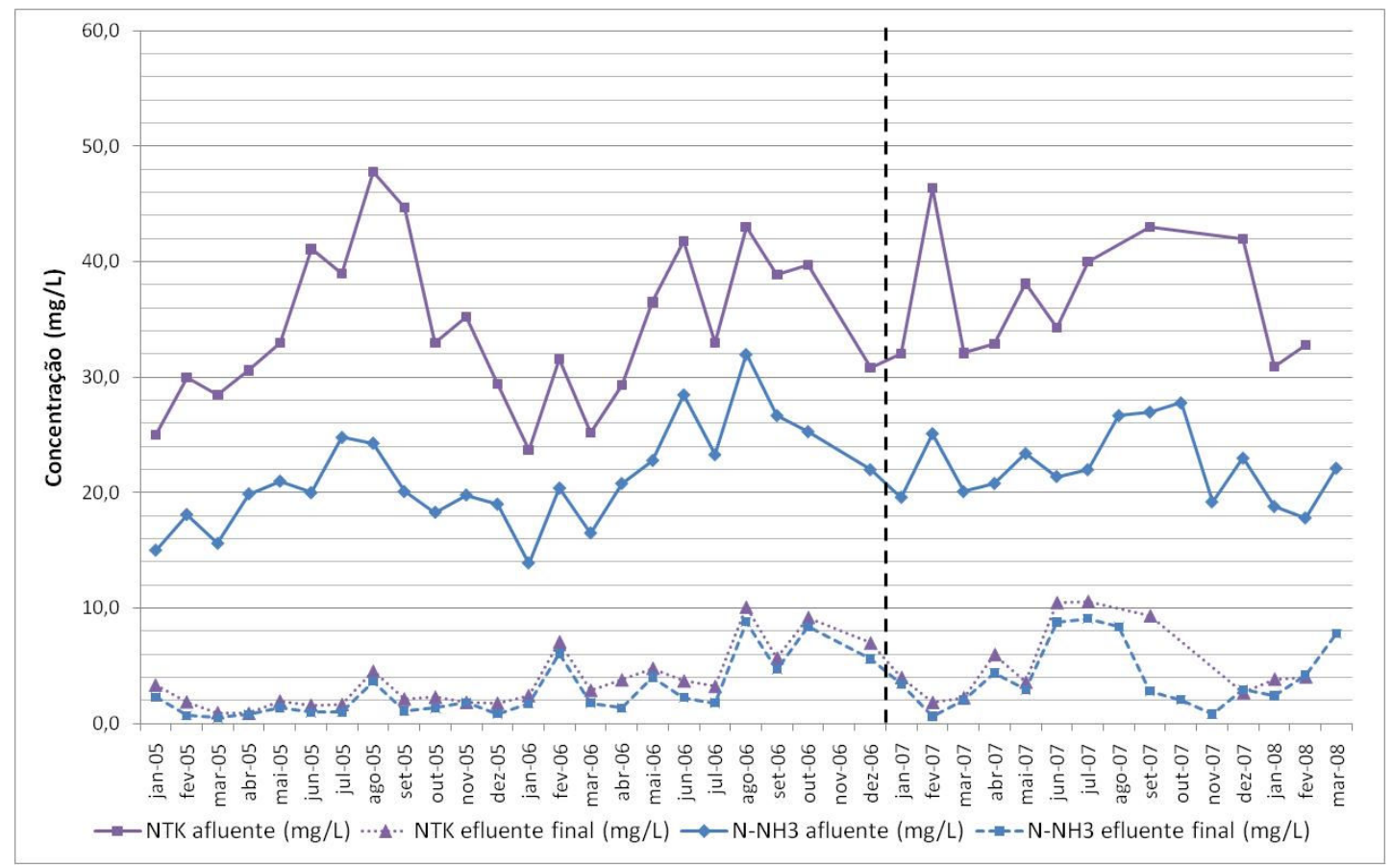

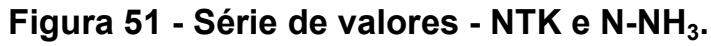

\subsubsection{Fósforo}

No período com lançamento de lodo da ETA na ETE, percebe-se que houve um aumento significativo na concentração de fósforo total afluente em relação ao período controle - em média, de 5,7 mg/L para $8,4 \mathrm{mg} / \mathrm{L}$ (46\%). Este aumento foi acompanhado de uma maior variação de valores, indicada pelo maior intervalo interquartil e pelos máximos e mínimos observados - as medições variaram de 3,0 a $17,8 \mathrm{mg} / \mathrm{L}$ no período (Tabela 6 e Tabela 7 ).

A Figura 52 apresenta o diagrama box-plot para os períodos antes e após o início do lançamento do lodo da ETA.

Este aumento na concentração de fósforo pode se justificar pela forma como este é removido da água bruta na ETA, via precipitação. Deste modo, o fósforo de fato é transferido para o lodo, sendo enviado com este para a ETE ABC. 


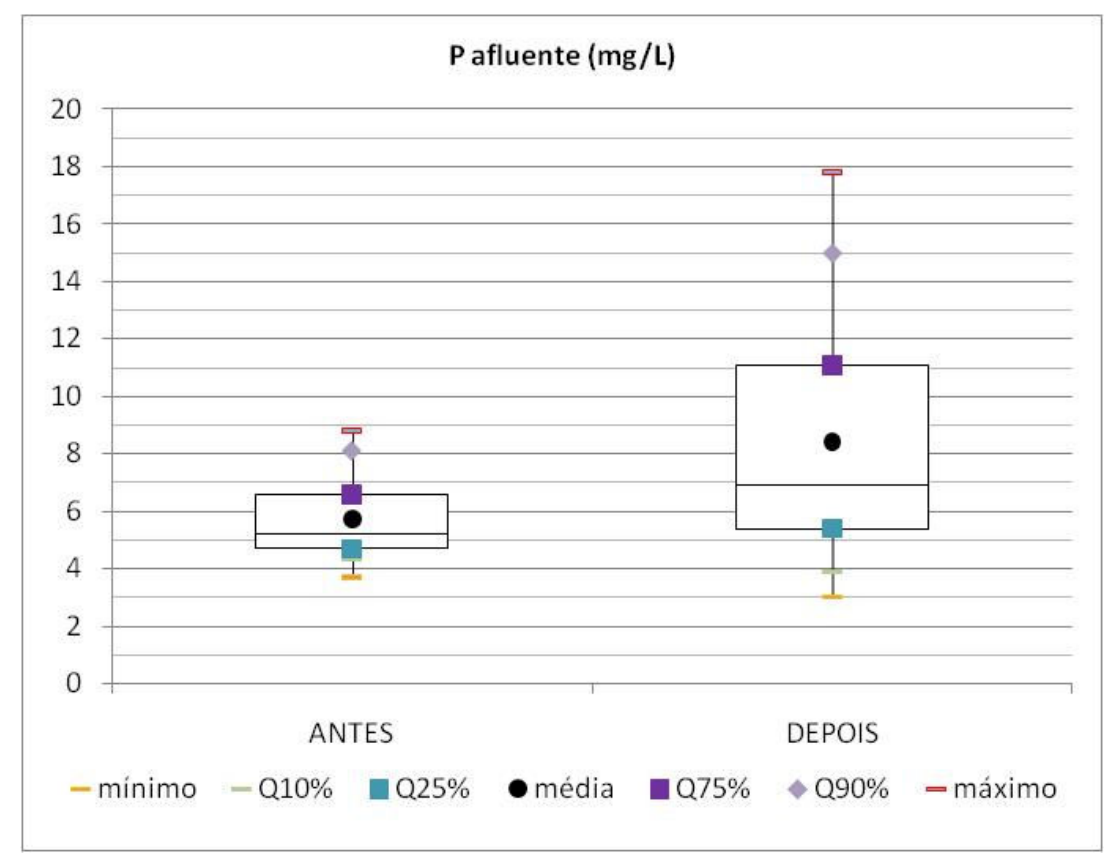

Figura 52 - Fósforo afluente (mg/L).

No caso do fósforo no efluente final da ETE $A B C$, percebe-se que no período com o lodo da ETA houve uma melhoria significativa da qualidade do esgoto efluente, com uma diminuição da concentração final de fósforo total de $74 \%$ na média - de 2,7 $\mathrm{mg} / \mathrm{L}$ para $0,7 \mathrm{mg} / \mathrm{L}$, de modo que a eficiência global de remoção na ETE aumentou em média de $70 \%$, sendo de $52 \%$ no período controle e passando para $88 \%$ no período com lodo.

Percebe-se ainda a ocorrência de máximos isolados na concentração de fósforo efluente no período com lodo da ETA, chegando a $18 \mathrm{mg} / \mathrm{L}$, os quais deslocam a média para valores maiores que a mediana. Assim, se formos considerar a mediana como parâmetro de comparação, o aumento de eficiência de remoção de fósforo na ETE foi maior ainda: passou para $96 \%$ no período após o lançamento do lodo da ETA, se encontrando na mesma faixa que de valores obtidas por Babatunde et al. (2009).

Esta melhoria era de fato esperada, sendo ela uma das principais consequências positivas do lançamento de lodo de ETA em ETE, conforme observado na literatura (BABATUNDE e ZHAO, 2007; BABATUNDE et al, 2009; BUENO et al., 2007; SUNDEFELD, 2007; ZHAO et al, 2008).

As Figura 53 e Figura 54 abaixo apresentam, respectivamente, os diagramas boxplot para o fósforo total efluente da ETE, nos dois períodos de estudo, e a eficiência 
global do processo de tratamento na estação. Apresenta-se também a série histórica dos valores observados (Figura 55). Nesta, é nítido o aumento na concentração de fósforo afluente e a diminuição no efluente, levando a uma maior eficiência de remoção na ETE.

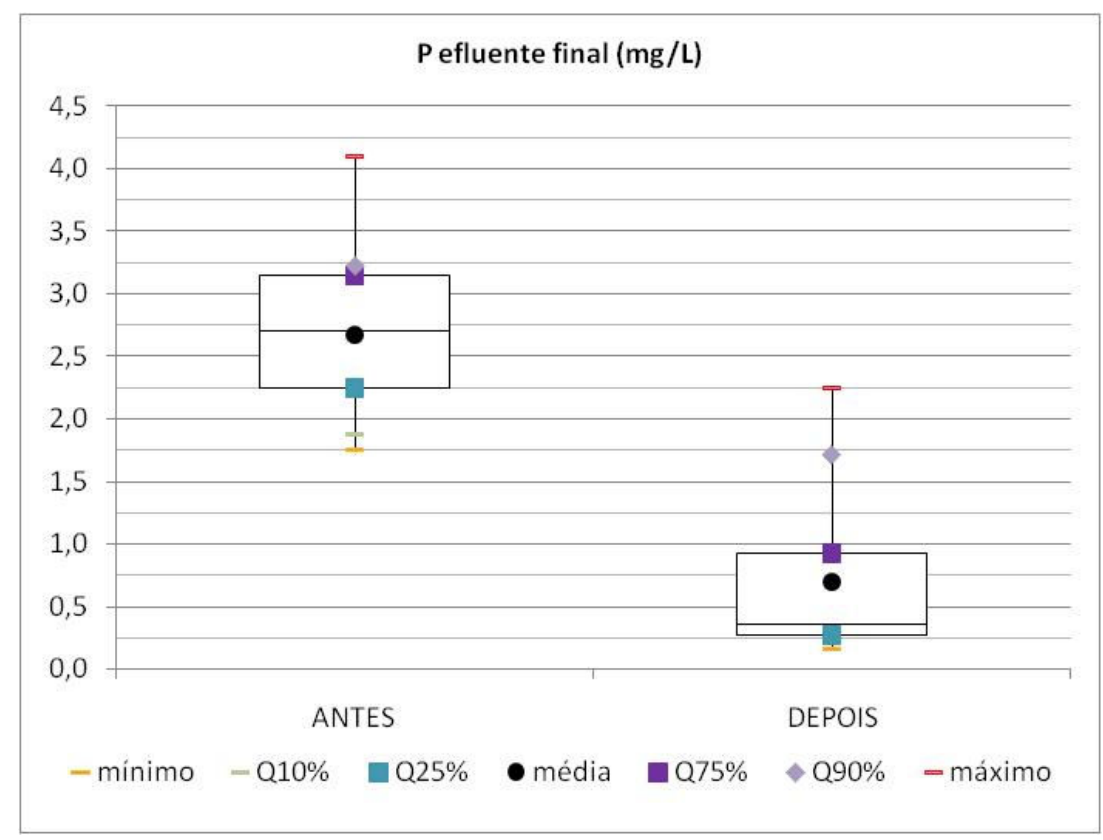

Figura 53 - Fósforo efluente final (mg/L).

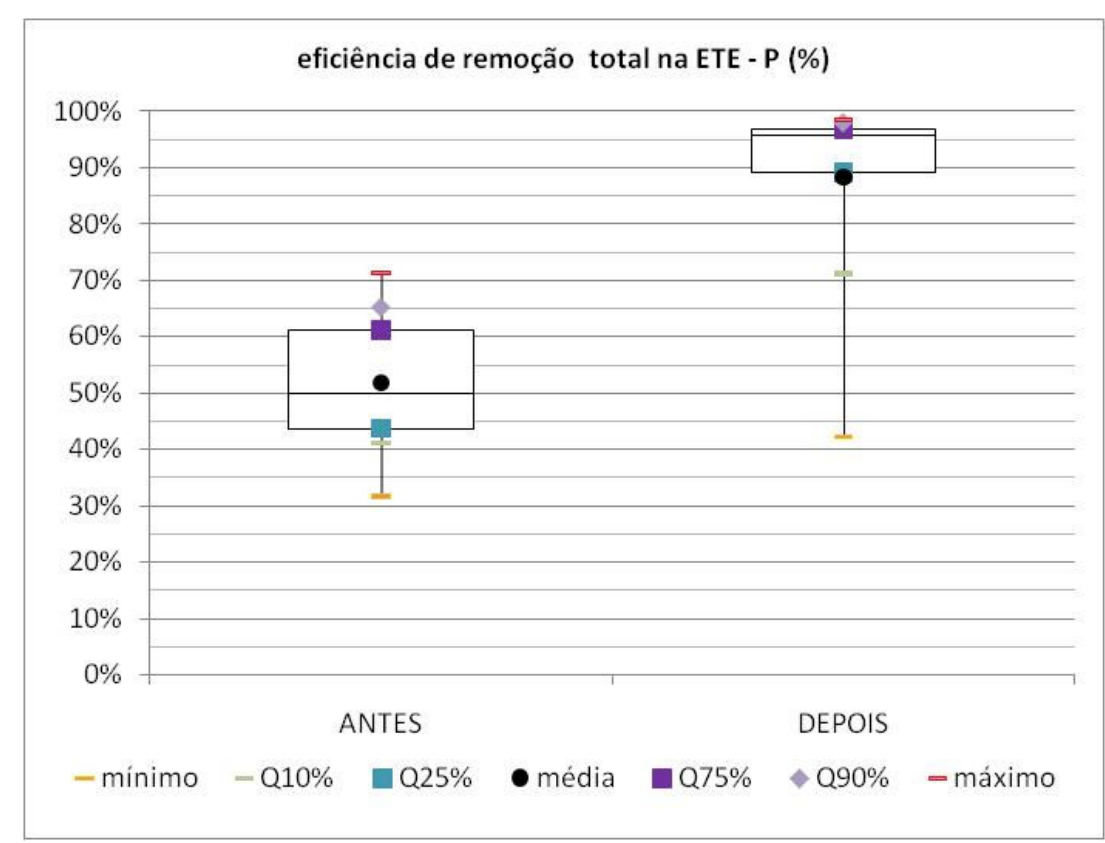

Figura 54 - Fósforo total: Eficiência de remoção total na ETE ABC (\%). 


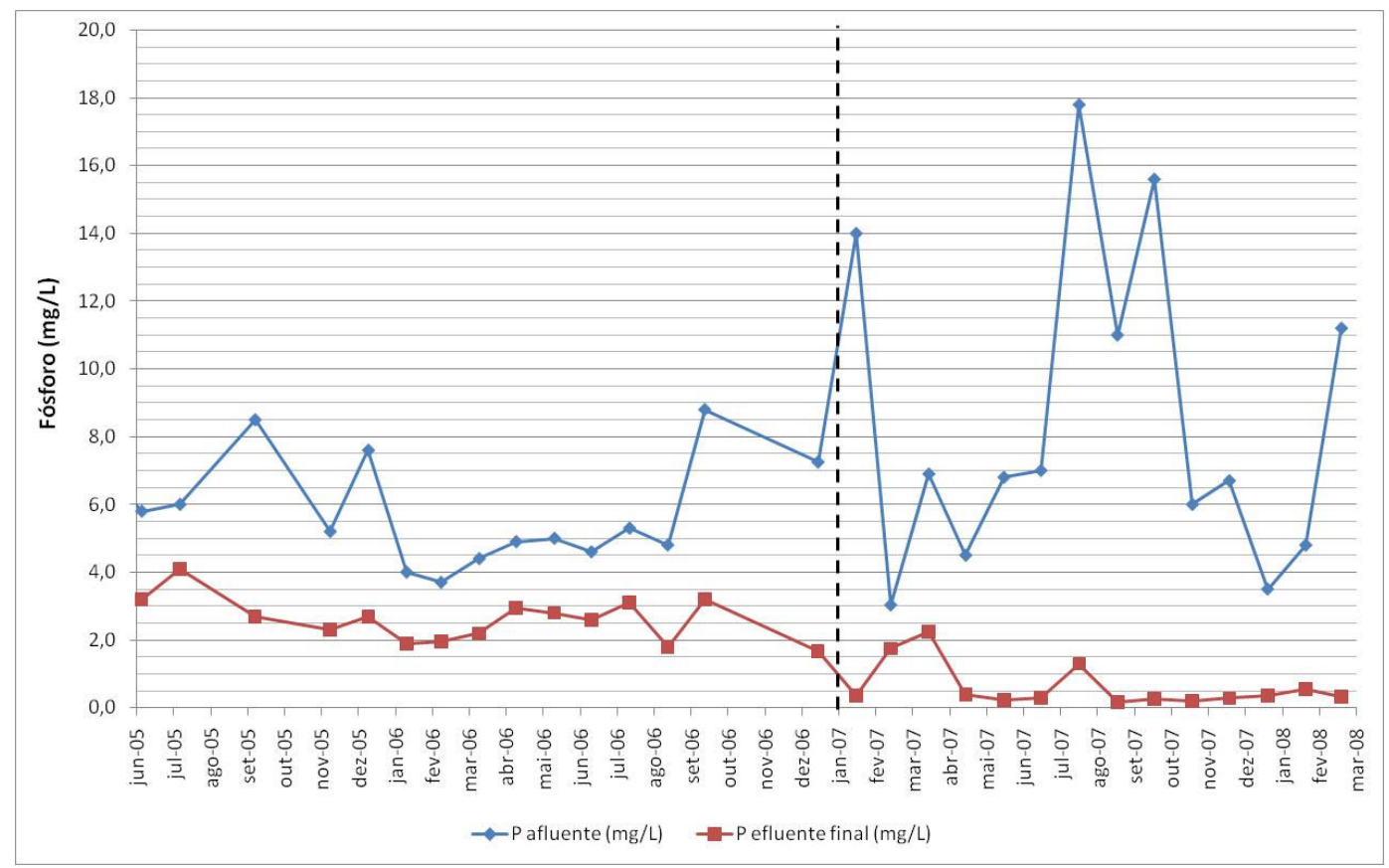

Figura 55 - Série de valores: Fósforo total no esgoto afluente e efluente final da ETE ABC.

\subsubsection{Ferro}

Conforme o esperado, a concentração de ferro total no esgoto afluente à ETE ABC aumentou após o início do lançamento do lodo da ETA Rio Grande, uma vez que o coagulante utilizado no tratamento da água é o sulfato férrico, de modo que o ferro, no processo de coagulação, floculação e sedimentação, precipita-se na forma de hidróxido, passando a constituir parcela importante do lodo formado.

A Figura 56 apresenta o diagrama box-plot comparando os dois períodos de estudo. Percebe-se que além de ter ocorrido aumento na concentração média afluente de ferro total, esta passou a apresentar maior variabilidade no período com o lodo.

$O$ acréscimo de ferro no afluente foi da ordem de $33 \mathrm{mg} / \mathrm{L}$, passando de $8 \mathrm{mg} / \mathrm{L}$ para $41 \mathrm{mg} / \mathrm{L}$ com a contribuição do lodo da ETA (Tabela 6 e Tabela 7). Partindo da mesma metodologia de análise feita para o acréscimo de SST, o aumento de concentração deveria ser da ordem de apenas $14 \mathrm{mg} / \mathrm{L}$. Assim, da mesma forma que para a variável SST, a contribuição do lodo se mostrou maior que o calculado, podendo ser justificada pelos mesmos motivos apresentados no caso dos sólidos. 


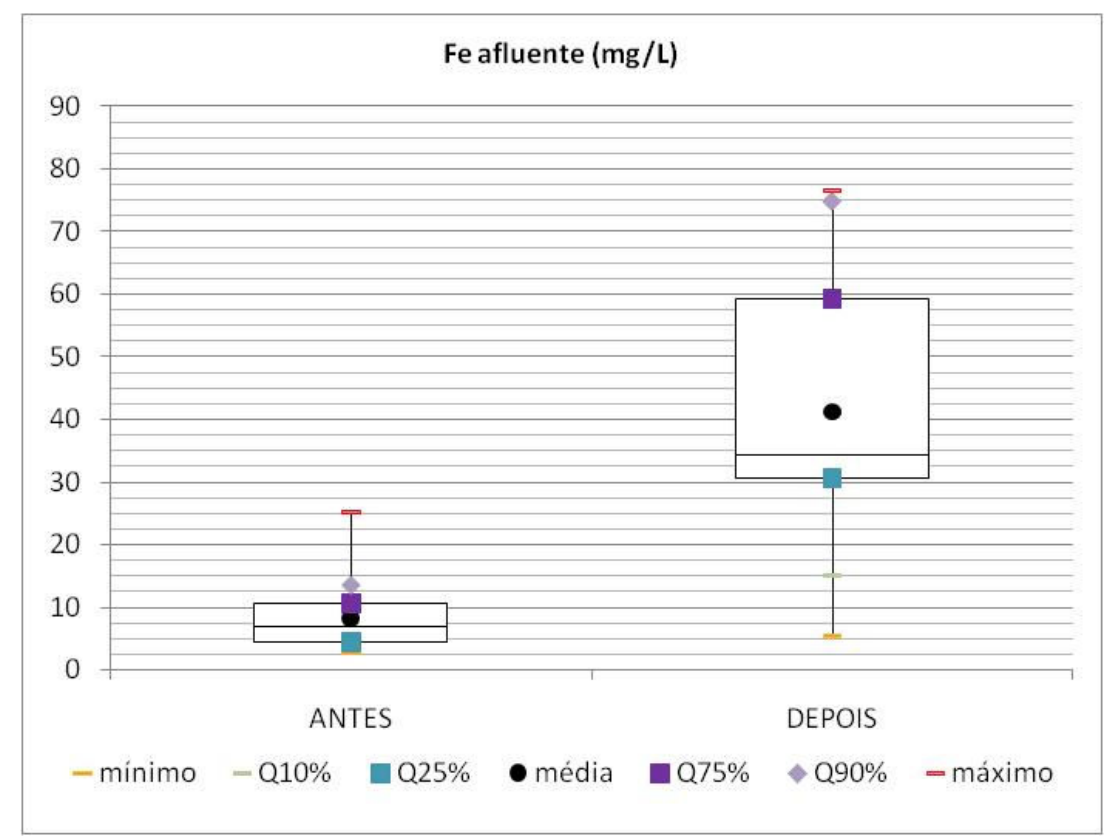

Figura 56 - Ferro total afluente (mg/L).

Em termos do efluente final, a concentração de ferro total praticamente não sofreu alterações, apenas um pequeno aumento de $0,5 \mathrm{mg} / \mathrm{L}$ para $0,9 \mathrm{mg} / \mathrm{L}$ (Figura 57 ), ou seja, continuou muito abaixo do padrão de lançamento estabelecido pelo Decreto 8468/76 e pela resolução CONAMA $n^{\circ} .357 / 05$, que definem $15 \mathrm{mg} / \mathrm{L}$ para o ferro, parcela dissolvida. $O$ aumento de eficiência notado na Figura 58 se deve ao fato apenas de a concentração afluente ter aumentado no período com o lodo da ETA.

Decorrente disto assume-se que o ferro continua sendo eliminado no processo pela sua precipitação na forma de hidróxido, saindo da fase líquida e passando para o lodo produzido na ETE ABC. 


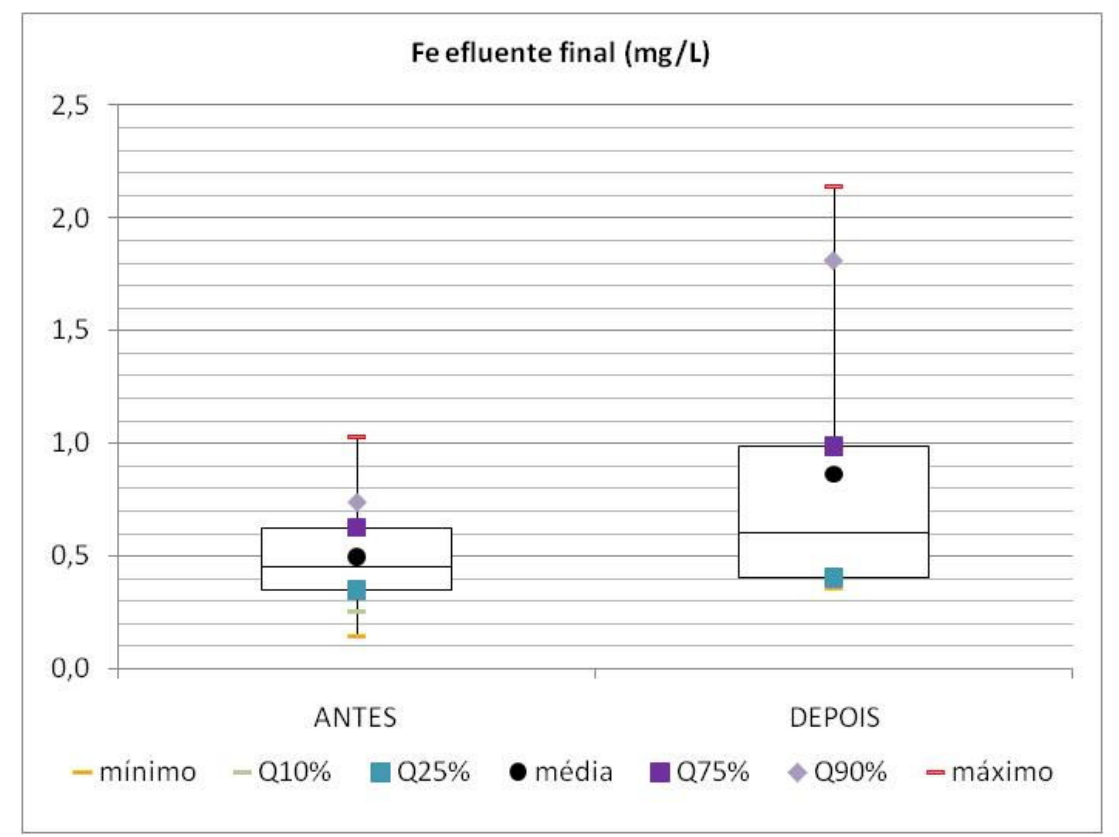

Figura 57 - Ferro total efluente final ( $\mathrm{mg} / \mathrm{L})$.

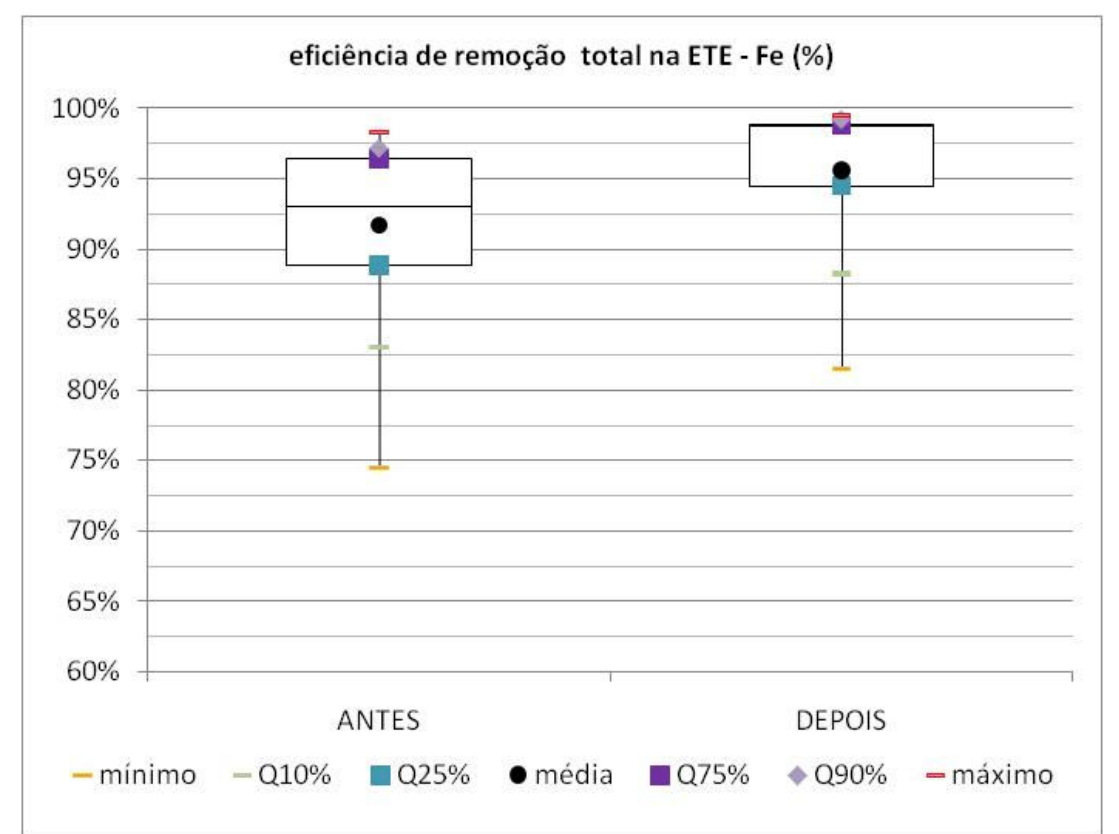

Figura 58 - Ferro total: Eficiência de remoção total na ETE ABC (\%). 


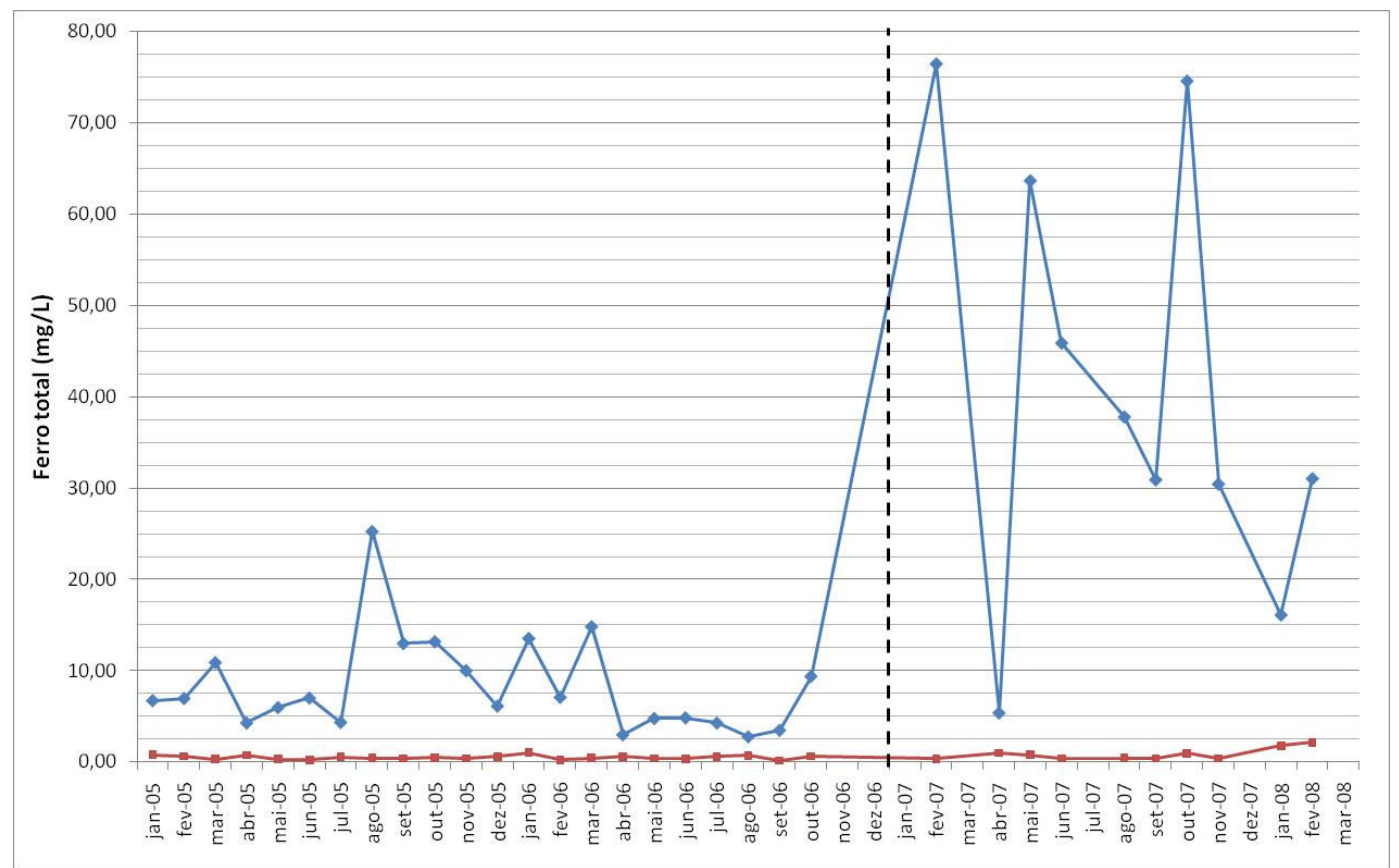

Figura 59 - Série de valores: Ferro total no esgoto afluente e efluente final da ETE ABC.

\subsection{Impactos nas unidades de tratamento de fase líquida e sólida}

Após analisar os impactos do lançamento do lodo da ETA na qualidade dos efluentes bruto e final da ETE $A B C$, convém identificar quais foram os impactos ocorridos em cada uma das unidades de tratamento, a saber:

- Tratamento preliminar e primário, através do decantador primário;

- Tratamento secundário, por meio do tanque de aeração e decantador secundário;

- Adensadores por gravidade e por flotação;

- Digestores;

- Filtros-prensa.

A análise de cada unidade é realizada através das variáveis de qualidade do esgoto (ou do lodo) na entrada e na saída da mesma, além dos parâmetros operacionais específicos. 


\subsubsection{Decantadores Primários}

A função de decantadores primários em uma ETE é remover a parcela de sólidos sedimentáveis, e com isso, diminuir parte da carga orgânica - principalmente o conteúdo particulado, transferindo estes para a fase sólida, constituída pelo lodo primário. As eficiências de remoção de SST giram em torno de 50\%, enquanto para o conteúdo orgânico, na forma de DBO, apresenta comumente eficiência de remoção da ordem de 30\% (METCALF e EDDY, 2003).

O parâmetro operacional relevante para unidades de sedimentação primária é a Taxa de Aplicação Superficial (TAS), relação entre a vazão em trânsito na unidade pela área superficial (em planta) da mesma. Valores de TAS da ordem de 30-50 $\mathrm{m}^{3} / \mathrm{m}^{2}$.dia são recomendados em literatura para a vazão média, e de 80-120 $\mathrm{m}^{3} / \mathrm{m}^{2}$.dia para a máxima horária (METCALF e EDDY, 2003). Pela Norma NBR 12.209, a TAS recomendada é de até $80 \mathrm{~m}^{3} / \mathrm{m}^{2}$.dia para as vazões máximas diárias, quando o decantador precede tratamento biológico (ABNT, 1992). Na ETE ABC em sua fase inicial, tal parâmetro operacional apresenta valores de projeto de 48 $\mathrm{m}^{3} / \mathrm{m}^{2}$.dia a $120 \mathrm{~m}^{3} / \mathrm{m}^{2}$.dia para vazão média, sendo considerados até quatro decantadores primários em uso.

No período estudado, a ETE ABC operou entre 2 e 4 decantadores primários, com os seguintes valores de TAS, considerando uma área de decantação unitária de $1.350 \mathrm{~m}^{2}$, tendo cada decantador $75 \mathrm{~m}$ de comprimento e $18 \mathrm{~m}$ de largura (HIDROSERVICE, 1998):

Tabela 8 - Valores de TAS dos decantadores primários da ETE ABC, para vazão média.

\begin{tabular}{ccccccccc}
\hline Parâmetro & Período & $\mathbf{n}$ & média & \pm desvio & mediana & mín. & máx. & $\begin{array}{c}\text { coef. } \\
\text { var. }\end{array}$ \\
\hline Vazão & Controle & 24 & 1,33 & $\pm 0,09$ & 1,34 & 1,15 & 1,48 & $7 \%$ \\
$\left(\mathrm{~m}^{3} / \mathrm{s}\right)$ & Com lodo & 14 & $1,60 \pm 0,15$ & 1,56 & 1,45 & 1,99 & $9 \%$ \\
TAS & Controle & 24 & $37 \pm 7$ & 40 & 24 & 46 & $20 \%$ \\
$\left(\mathrm{~m}^{3} / \mathrm{m}^{2}\right.$.dia $)$ & Com lodo & 14 & $35 \pm 9$ & 33 & 24 & 56 & $24 \%$ \\
\hline
\end{tabular}

Pode-se notar na Tabela 8 que em ambos os períodos a TAS permaneceu abaixo dos valores de projeto. Desta forma, presume-se que a qualidade do efluente primário permanecerá livre de impactos negativos decorrentes do lançamento do lodo da ETA Rio Grande na ETE, uma vez que a capacidade de decantação na unidade é maior quanto menor a TAS. 
Isto é comprovado pelos valores obtidos para as remoções de sólidos suspensos (voláteis e totais) e matéria orgânica, apresentados respectivamente na Figura 61e na Figura 64: para os primeiros, os valores médios se mantiveram acima de $40 \%$; para DBO e DQO, a eficiência média de remoção foi da ordem $40 \%$ para a primeira e $30 \%$ para a segunda, condizentes com os valores da literatura (METCALF e EDDY, 2003).

Em todos os casos, houve melhoria na eficiência de remoção no período com lodo, mesmo com algum aumento no valor de concentração no efluente primário. Esta melhoria de eficiência foi mais significativa para o fósforo e para o ferro, decorrente principalmente do aumento destas concentrações no esgoto afluente e manutenção da qualidade no efluente primário - salvo ocorrência de picos no final do período seco em 2007 -, conforme pode ser observado na Tabela 9 e nos gráficos abaixo (Figura 60 a Figura 65):

Tabela 9 - Variáveis monitoradas no efluente primário da ETE ABC - períodos controle e com lodo.

\begin{tabular}{|c|c|c|c|c|c|c|c|}
\hline Variável & Período & $\mathbf{n}$ & média \pm desvio & mediana & mínimo & máximo & $\begin{array}{c}\text { Eficiência de } \\
\text { remoção média } \\
\text { dos } \\
\text { decantadores }\end{array}$ \\
\hline \multirow{2}{*}{ SST (mg/L) } & Controle & 22 & $162 \pm 51$ & 147 & 101 & 287 & $39 \% \pm 12 \%$ \\
\hline & Com lodo & 15 & $181 \pm 79$ & 163 & 82 & 390 & $48 \% \pm 16 \%$ \\
\hline \multirow{2}{*}{ SSV mg/L) } & Controle & 22 & $105 \pm 28$ & 95 & 68 & 165 & $40 \% \pm 11 \%$ \\
\hline & Com lodo & 15 & $110 \pm 52$ & 98 & 45 & 246 & $48 \% \pm 17 \%$ \\
\hline \multirow{2}{*}{ DBO (mg/L) } & Controle & 22 & $124 \pm 36$ & 113 & 77 & 237 & $39 \% \pm 11 \%$ \\
\hline & Com lodo & 15 & $169 \pm 83$ & 154 & 72 & 386 & $43 \% \pm 12 \%$ \\
\hline \multirow{2}{*}{$\mathrm{DQO}(\mathrm{mg} / \mathrm{L})$} & Controle & 24 & $297 \pm 57$ & 285 & 199 & 398 & $30 \% \pm 9 \%$ \\
\hline & Com lodo & 13 & $325 \pm 109$ & 293 & 187 & 536 & $34 \% \pm 12 \%$ \\
\hline \multirow{2}{*}{ NTK (mg/L) } & Controle & 23 & $32 \pm 5$ & 32 & 24 & 42 & $7 \% \pm 8 \%$ \\
\hline & Com lodo & 11 & $30 \pm 5$ & 29 & 24 & 40 & $16 \% \pm 13 \%$ \\
\hline \multirow{2}{*}{$\begin{array}{l}\text { Fósforo total } \\
\qquad(\mathrm{mg} / \mathrm{L})\end{array}$} & Controle & 19 & $5,0 \pm 1,0$ & 4,6 & 3,1 & 7,0 & $13 \% \pm 13 \%$ \\
\hline & Com lodo & 15 & $4,4 \pm 2,8$ & 3,9 & 1,3 & 9,8 & $45 \% \pm 24 \%$ \\
\hline \multirow{2}{*}{$\begin{array}{c}\text { Ferro total } \\
(\mathrm{mg} / \mathrm{L})\end{array}$} & Controle & 22 & $5,5 \pm 4,0$ & 4,1 & 1,5 & 17,8 & $33 \% \pm 19 \%$ \\
\hline & Com lodo & 10 & $16,6 \pm 10,8$ & 12,4 & 3,9 & 36,7 & $51 \% \pm 27 \%$ \\
\hline
\end{tabular}




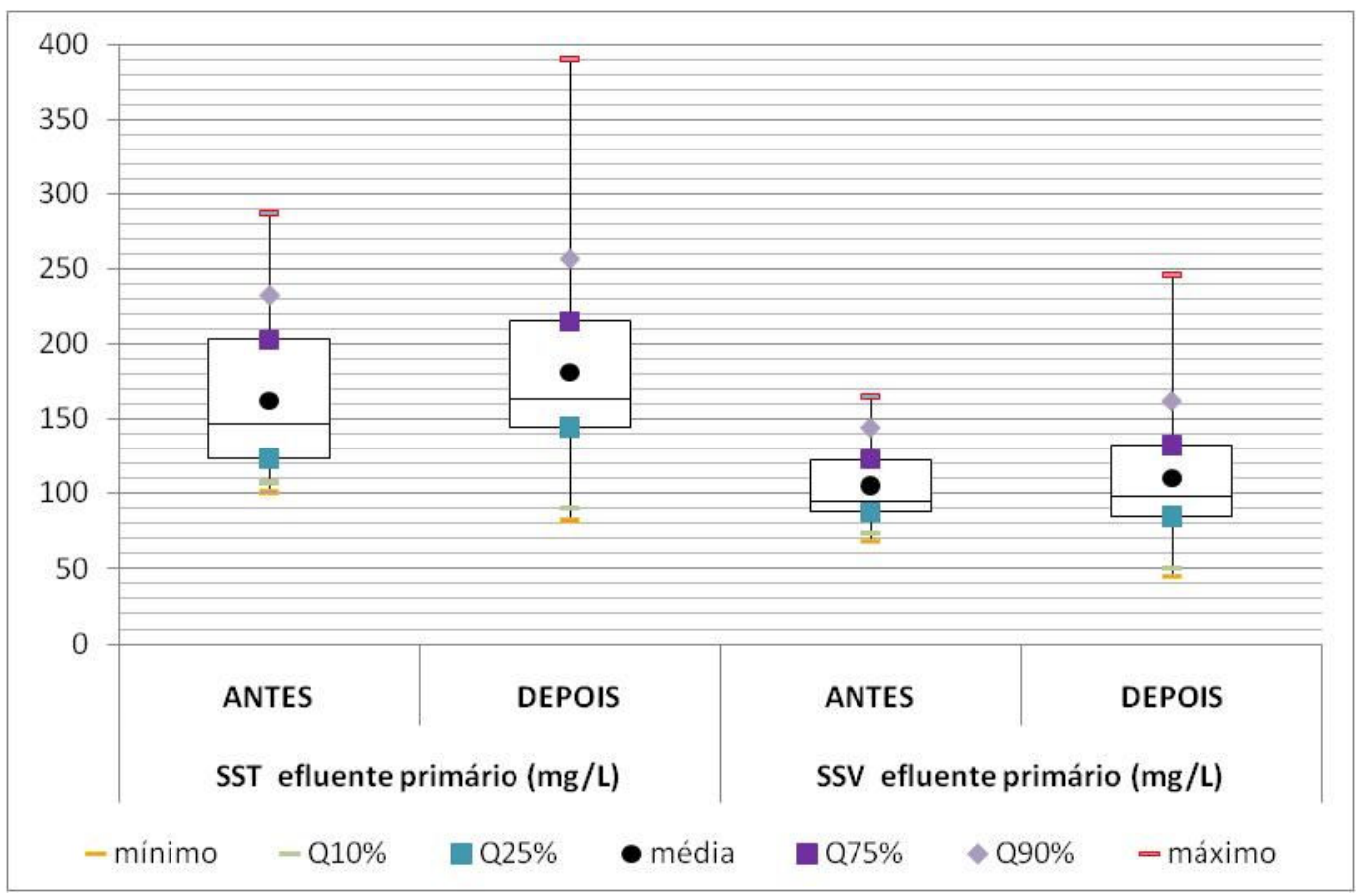

Figura 60 - SST e SSV no efluente primário (mg/L).

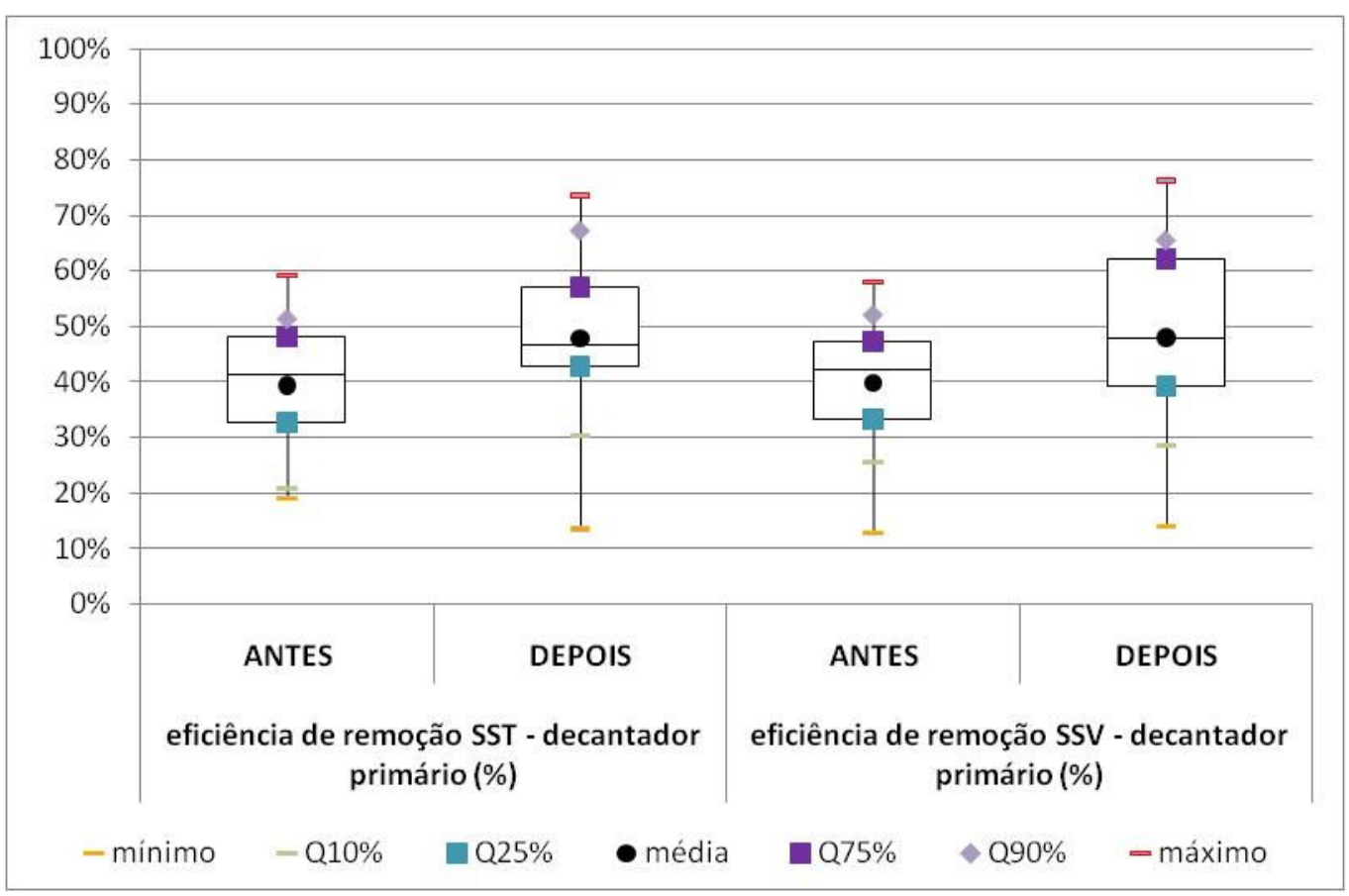

Figura 61 - SST e SSV: Eficiência de remoção nos decantadores primários (\%). 


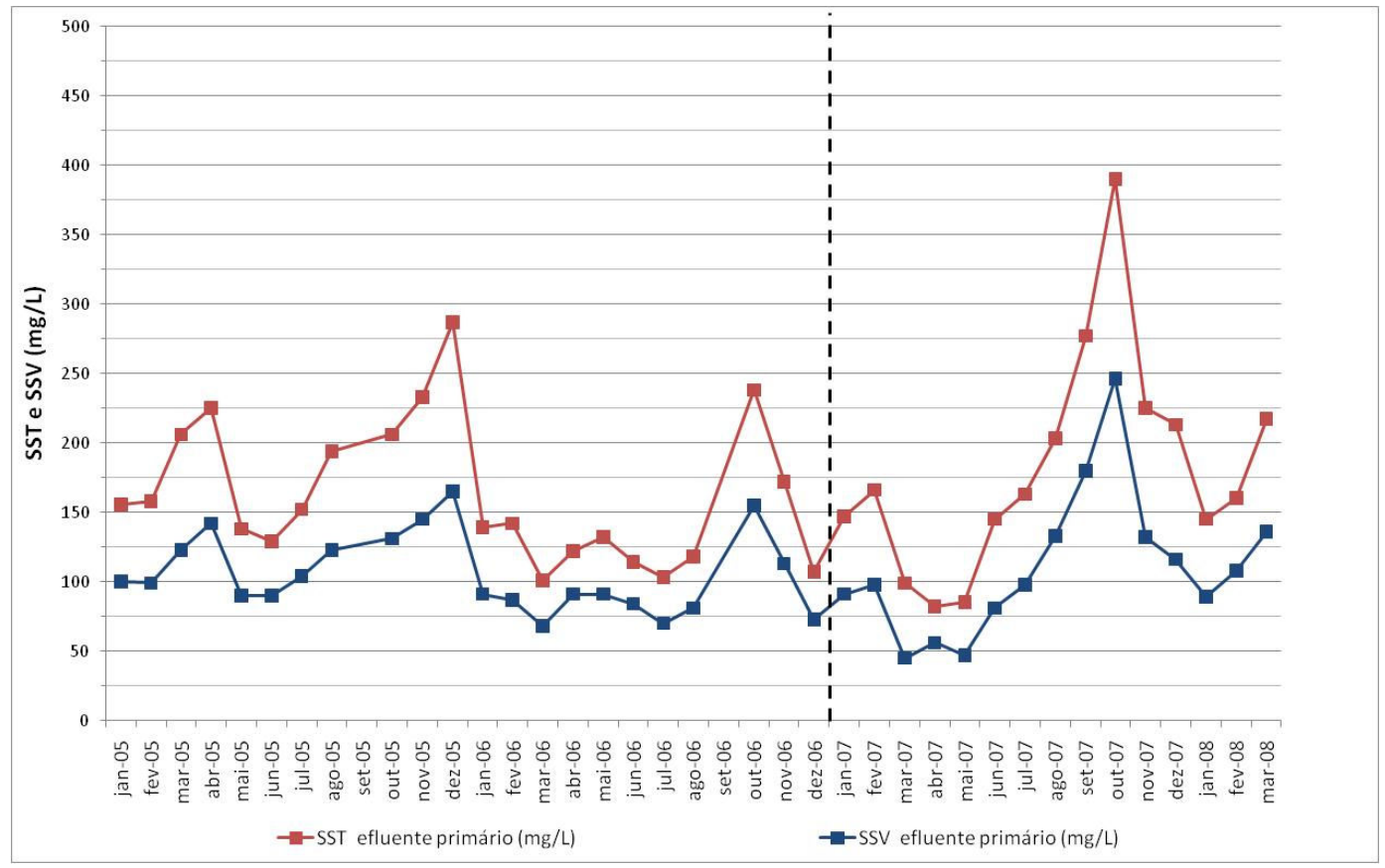

Figura 62 - Série de valores: SST e SSV no efluente primário.

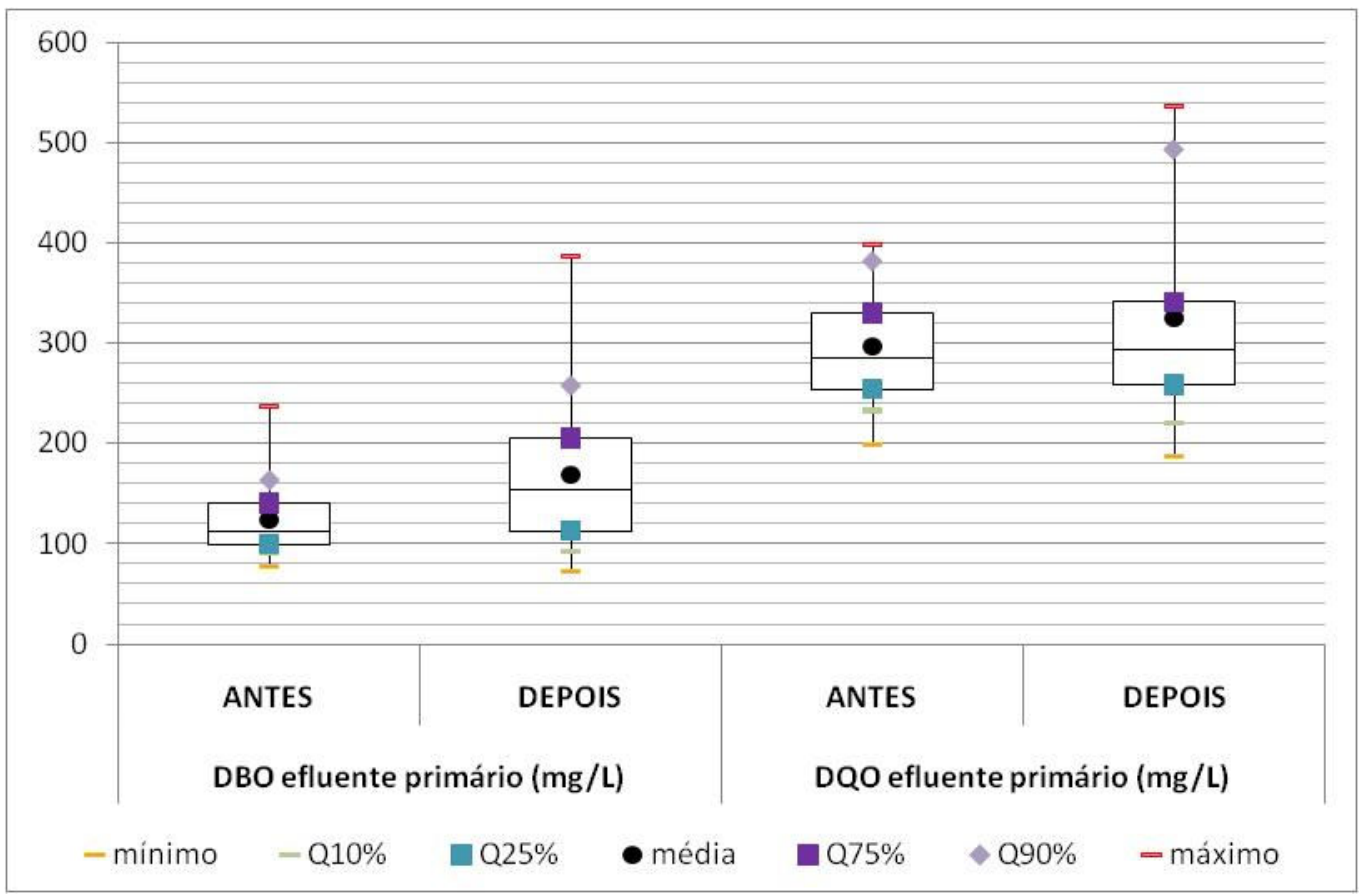

Figura 63 - DBO e DQO no efluente primário (mg/L). 


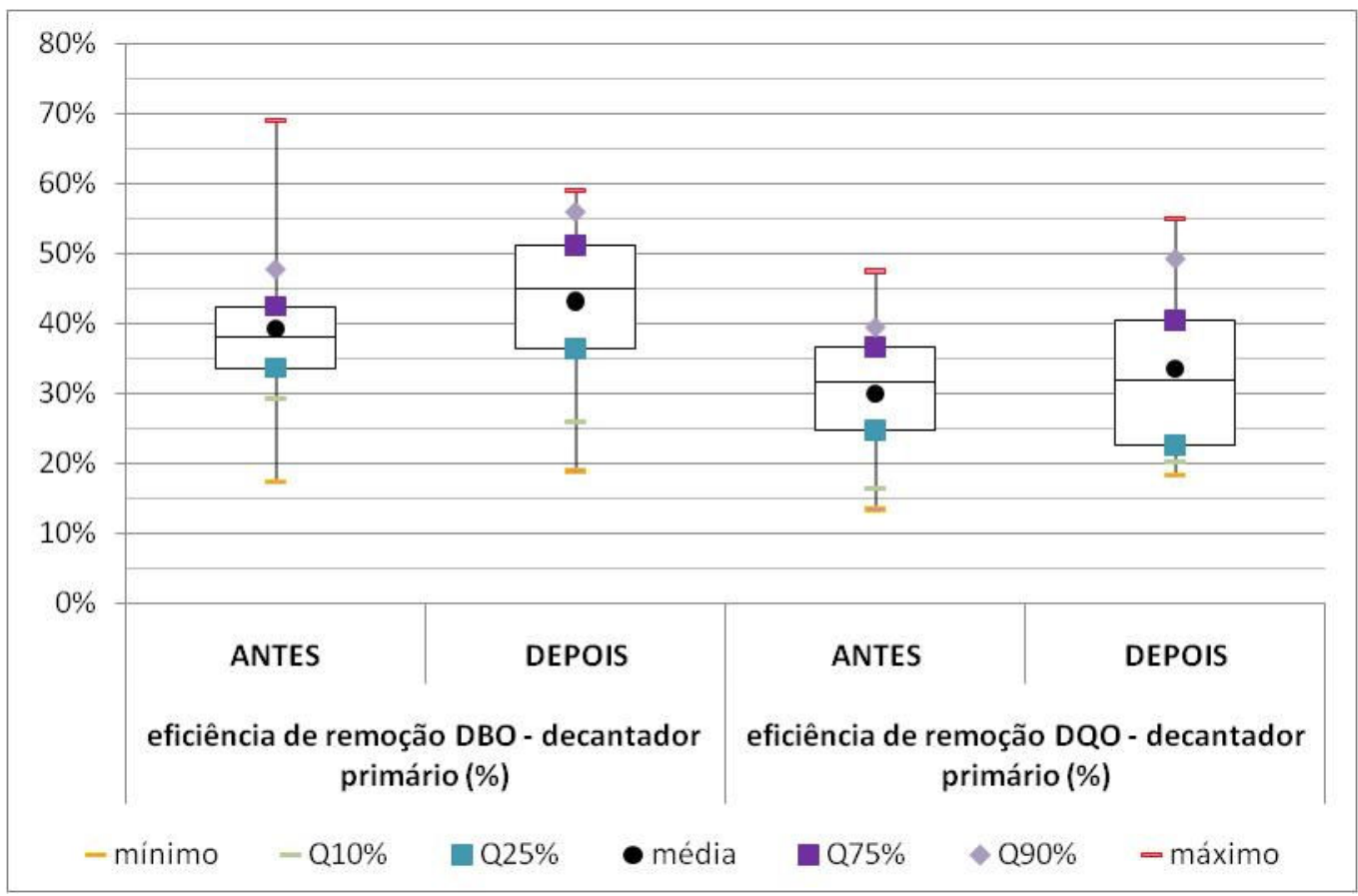

Figura 64 - DBO e DQO: Eficiência de remoção nos decantadores primários (\%).

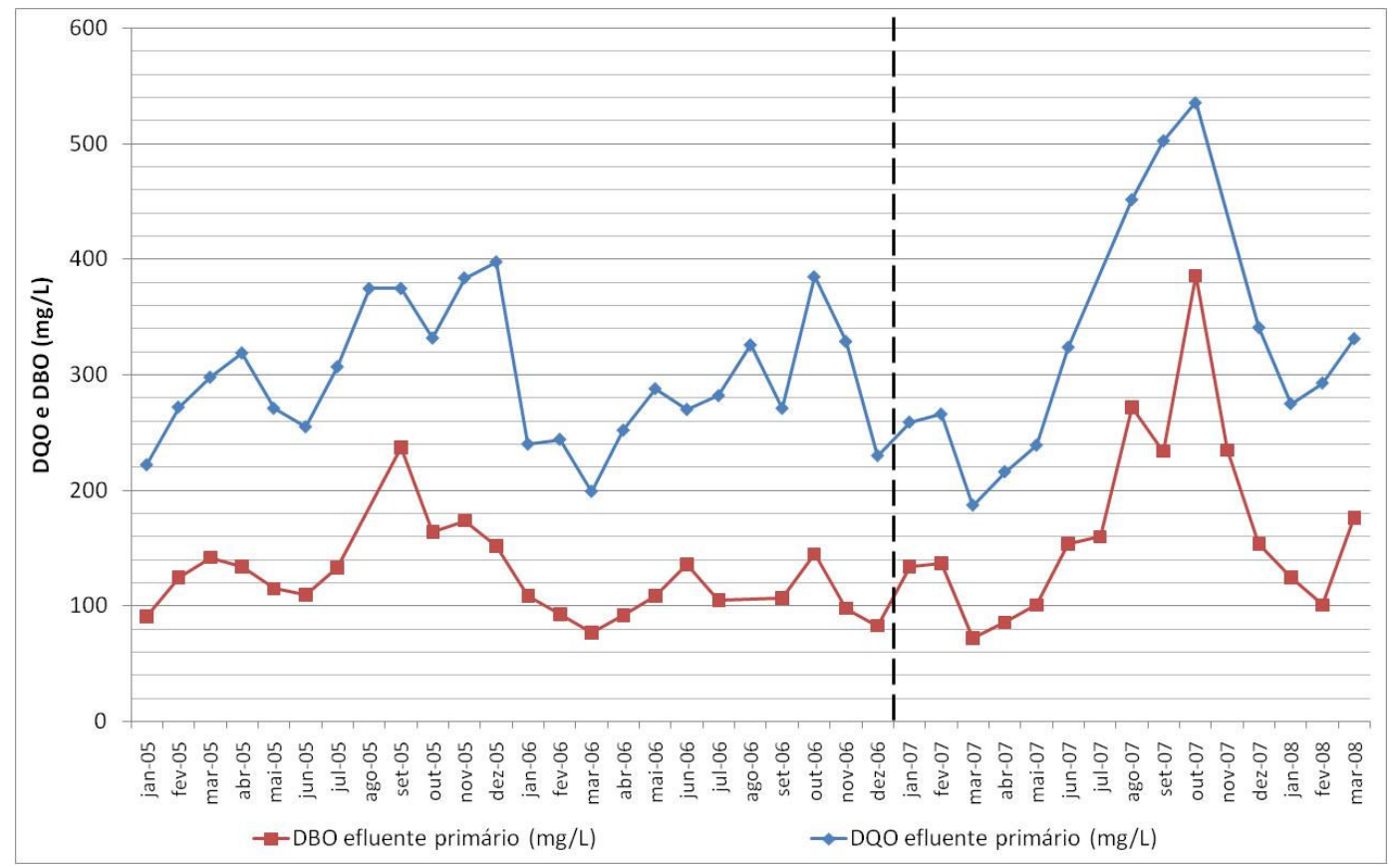

Figura 65 - Série de valores: DBO e DQO no efluente primário da ETE ABC.

O maior aumento de eficiência ocasionado pela adição de lodo nas remoções de fósforo (Tabela 9 e Figura 66) está de acordo com o observado na literatura (BABATUNDE e ZHAO, 2007; BUENO et al., 2007), ocorrendo sua remoção para a fase sólida: o fósforo é adsorvido nos flocos formados pela contribuição do coagulante advindo com o lodo da ETA. Já o ferro precipita na forma de hidróxido, 
arrastando consigo material suspenso. Porém, mesmo com maior remoção no período com lodo (Figura 68), o efluente dos decantadores primários apresenta maior concentração de ferro do que no período controle (Figura 69).

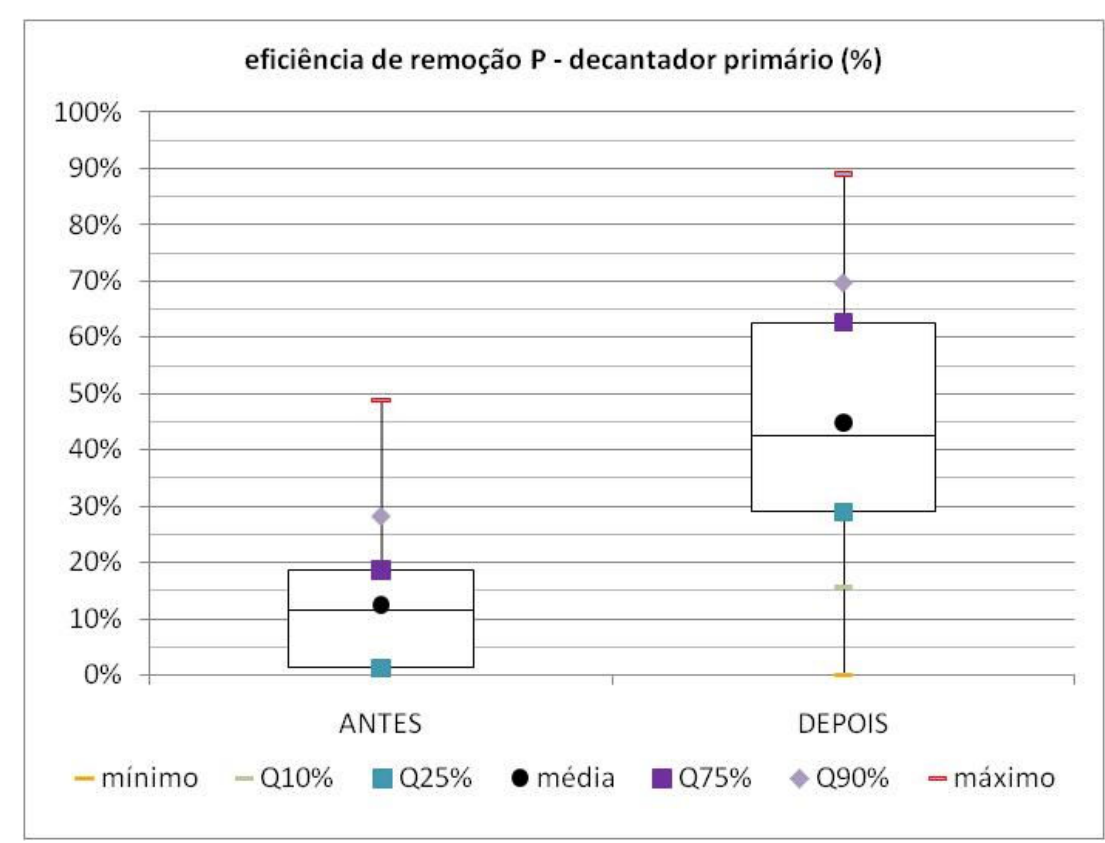

Figura 66 - Fósforo total: Eficiência de remoção no decantador primário (\%).

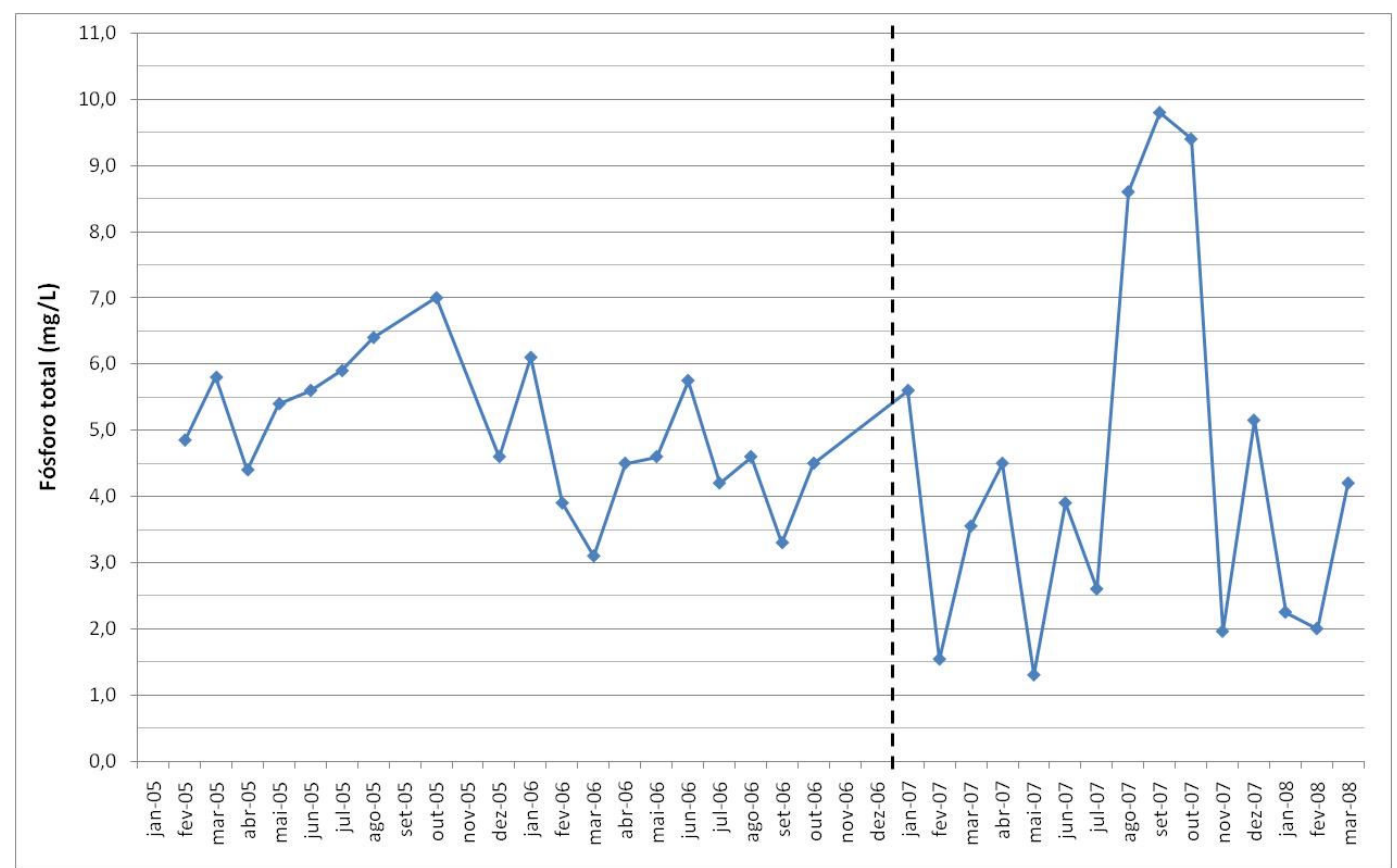

Figura 67 - Série de valores: Fósforo total no efluente primário da ETE ABC. 


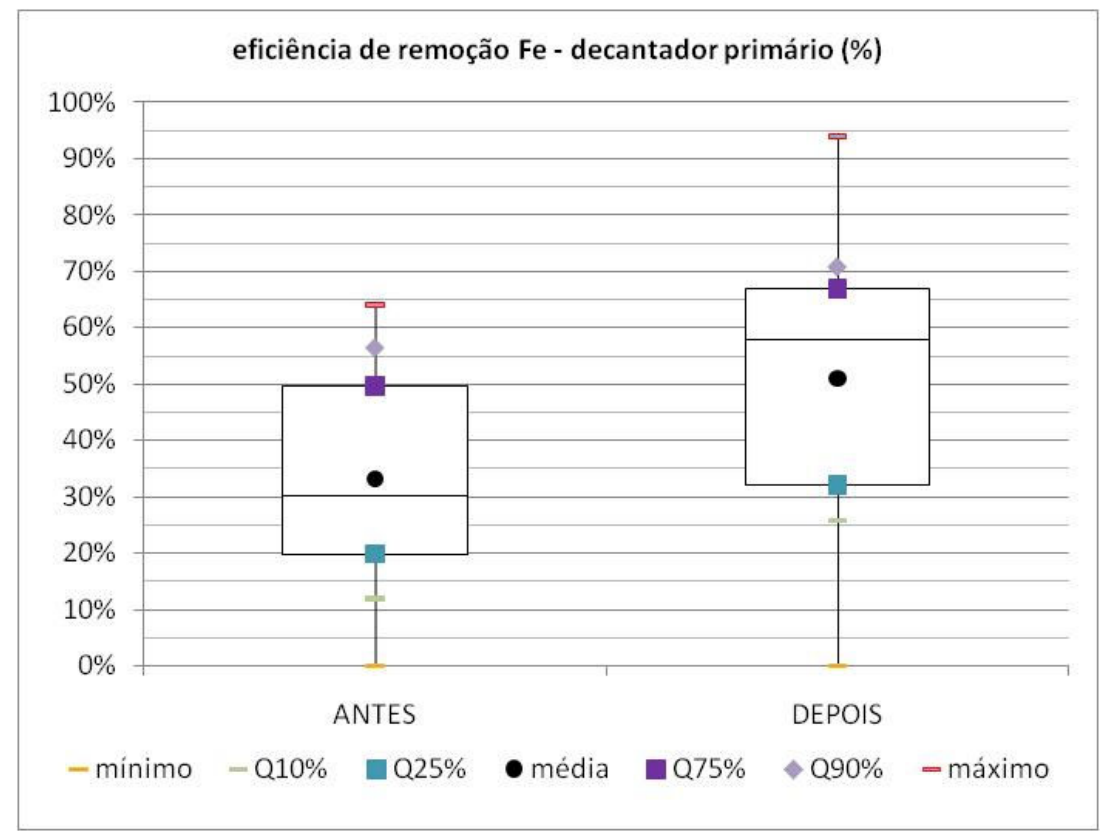

Figura 68 - Ferro total: Eficiência de remoção no decantador primário (\%).

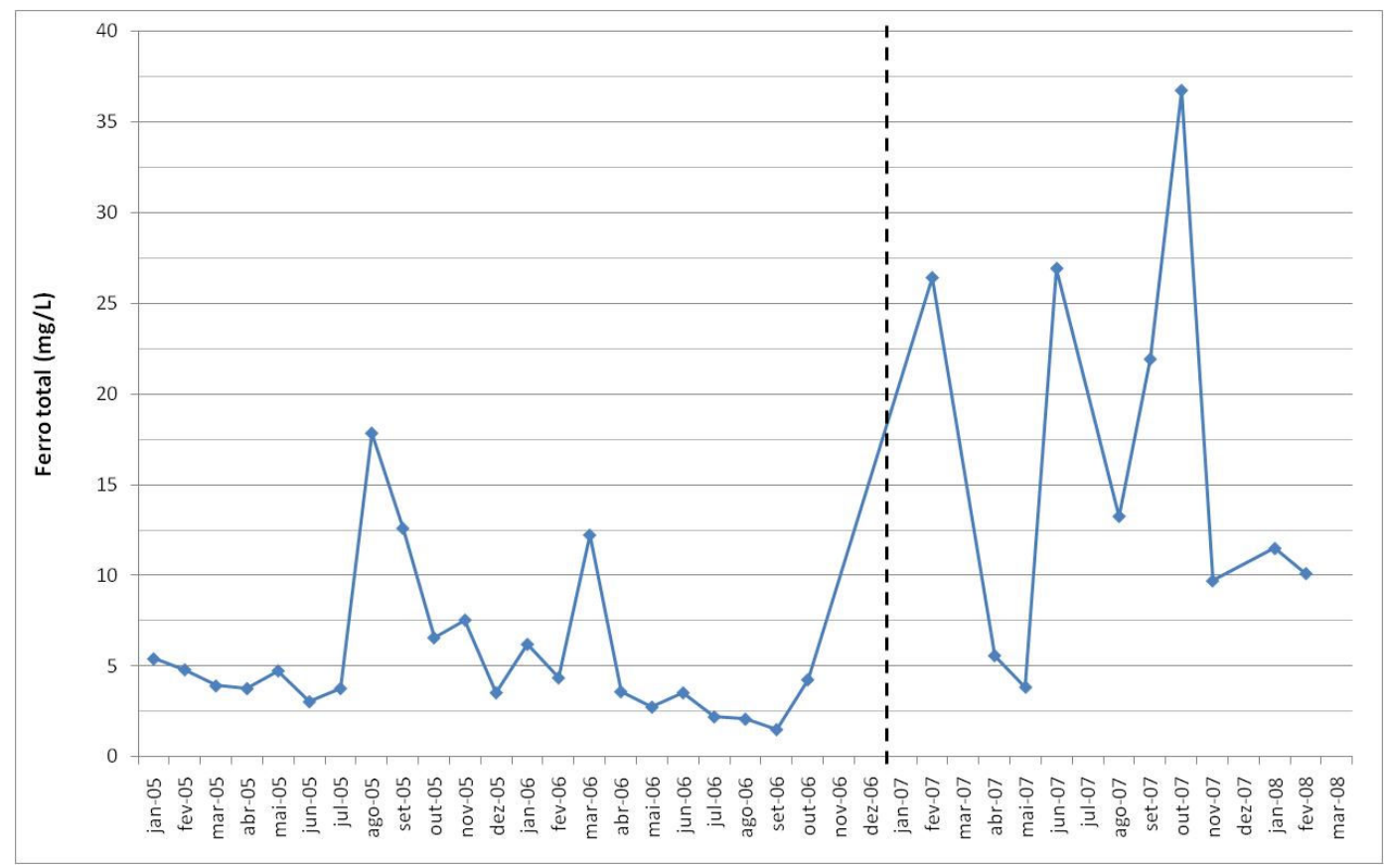

Figura 69 - Série de valores: Ferro total no efluente primário.

Ao se analisar a produção de lodo nos decantadores, confirma-se também que, com a contribuição do lodo da ETA, ocorre um aumento em termos de volume e uma diminuição sutil (na mediana) no teor de sólidos no lodo primário, conforme observado por Carvalho (2000) e Scalize (2003). Interessante notar que a diminuição no teor de sólidos voláteis no período com lodo foi maior que dos sólidos 
totais, indicando o caráter inorgânico do lodo da ETA. A Tabela 10 e os gráficos das Figura 70 e Figura 71 apresentam estas mudanças:

Tabela 10 - Variáveis monitoradas no lodo primário da ETE ABC - períodos controle e com lodo.

\begin{tabular}{ccccccccc}
\hline Variável & Período & $\mathbf{n}$ & média & \pm desvio & mediana & mín. & máx. & $\begin{array}{c}\text { coef. } \\
\text { var. }\end{array}$ \\
\hline Vazão de Lodo & Controle & 24 & 7,21 & $\pm 3,05$ & 6,71 & 2,77 & 13,5 & $42 \%$ \\
Primário (L/s) & Com lodo & 15 & 10,51 & $\pm 3,56$ & 10,28 & 3,34 & 16,5 & $34 \%$ \\
SST - Lodo & Controle & 23 & 27.572 & \pm 3.816 & 27.947 & 21.857 & 36.206 & $14 \%$ \\
Primário (mg/L) & Com lodo & 15 & 28.932 & \pm 7.371 & 27.112 & 17.925 & 44.329 & $25 \%$ \\
SSV - Lodo & Controle & 24 & 16.194 & \pm 2.171 & 15.654 & 12.334 & 20.012 & $13 \%$ \\
Primário (mg/L) & Com lodo & 15 & 14.892 & \pm 2.287 & 14.866 & 10.233 & 19.307 & $15 \%$ \\
\hline
\end{tabular}

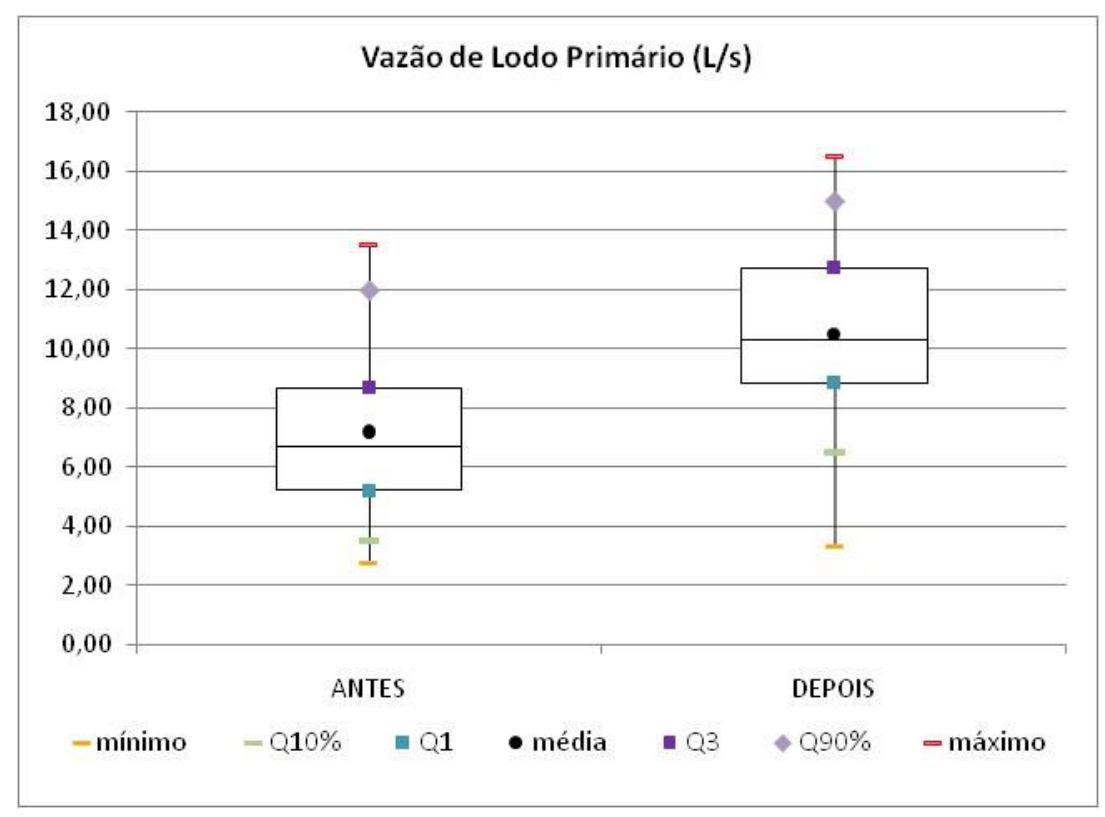

Figura 70 - Vazão de Lodo Primário (L/s). 


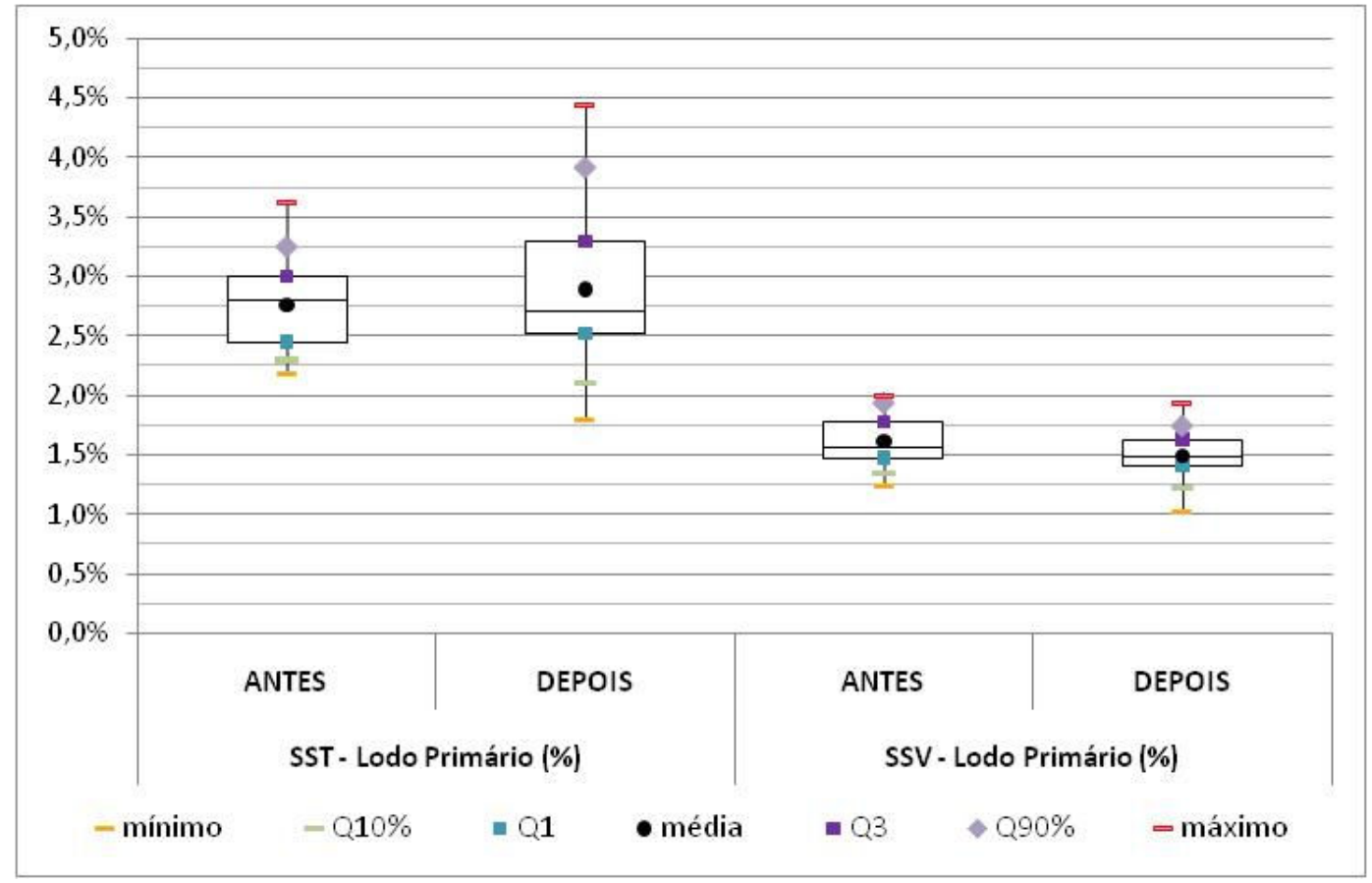

Figura 71 - SST e SSV no Lodo Primário (\%).

\subsubsection{Adensadores por Gravidade}

A ETE ABC conta com quatro tanques adensadores de lodo primário, que operam por gravidade, a fim de atingir um teor de sólidos da ordem de $7,5 \%$, segundo valores de projeto (HIDROSERVICE, 1998).

Os parâmetros operacionais de maior importância em instalações de adensamento por gravidade são a TAS, a qual se recomenda estar na faixa de 16 a $38 \mathrm{~m}^{3} / \mathrm{m}^{2}$.dia; e a taxa de aplicação de sólidos (TASol), medida em toneladas de sólidos (SST) aplicada por dia por unidade de área $\left(\mathrm{kg} / \mathrm{m}^{2}\right.$.dia), que deve se situar na faixa de 100 a $150 \mathrm{~kg} / \mathrm{m}^{2}$.dia (ABNT, 1992; METCALF \& EDDY, 2003).

A Tabela 11 abaixo apresenta os valores de TAS e TASol para ambos os períodos estudados, considerando o uso de um ou dois adensadores, cada um com $660 \mathrm{~m}^{2}$ de área: 
Tabela 11 - Parâmetros operacionais monitorados nos Adensadores por Gravidade - períodos controle e com lodo.

\begin{tabular}{ccccccccc}
\hline Parâmetro & Período & $\mathbf{n}$ & média & \pm desvio & mediana & mín. & máx. & $\begin{array}{c}\text { coef. } \\
\text { var. }\end{array}$ \\
\hline \multirow{3}{*}{ TAS $\left(\mathrm{m}^{3} / \mathrm{m}^{2}\right.$.dia) } & Projeto & - & $16 \pm-$ & - & - & - & - \\
& Controle & 24 & $0,7 \pm 0,3$ & 0,7 & 0,3 & 1,8 & $48 \%$ \\
& Com lodo & 15 & $1,2 \pm 0,5$ & 1,2 & 0,2 & 2,2 & $46 \%$ \\
& Projeto & - & $42 \pm-$ & - & - & 74 & - \\
TASol $\left(\mathrm{kg} / \mathrm{m}^{2}\right.$.dia) $)$ & Controle & 23 & $18,4 \pm 7,1$ & 17,9 & 9,6 & 40,5 & $39 \%$ \\
& Com lodo & 15 & $33,5 \pm 16,3$ & 33,3 & 5,4 & 60,1 & $49 \%$ \\
\hline
\end{tabular}

A partir destes dados, pode-se perceber que em ambos os períodos os adensadores operaram com substancial folga de capacidade, tanto para a contribuição média quanto para os valores máximos. Desta forma, não se espera qualquer diminuição de desempenho destas unidades, mesmo com o aumento volumétrico do lodo primário após a chegada do lodo da ETA Rio Grande. Isto pode ser percebido na Figura 72 abaixo, que apresenta os box-plot para a quantidade de SST e SSV no lodo adensado (em teor de sólidos):

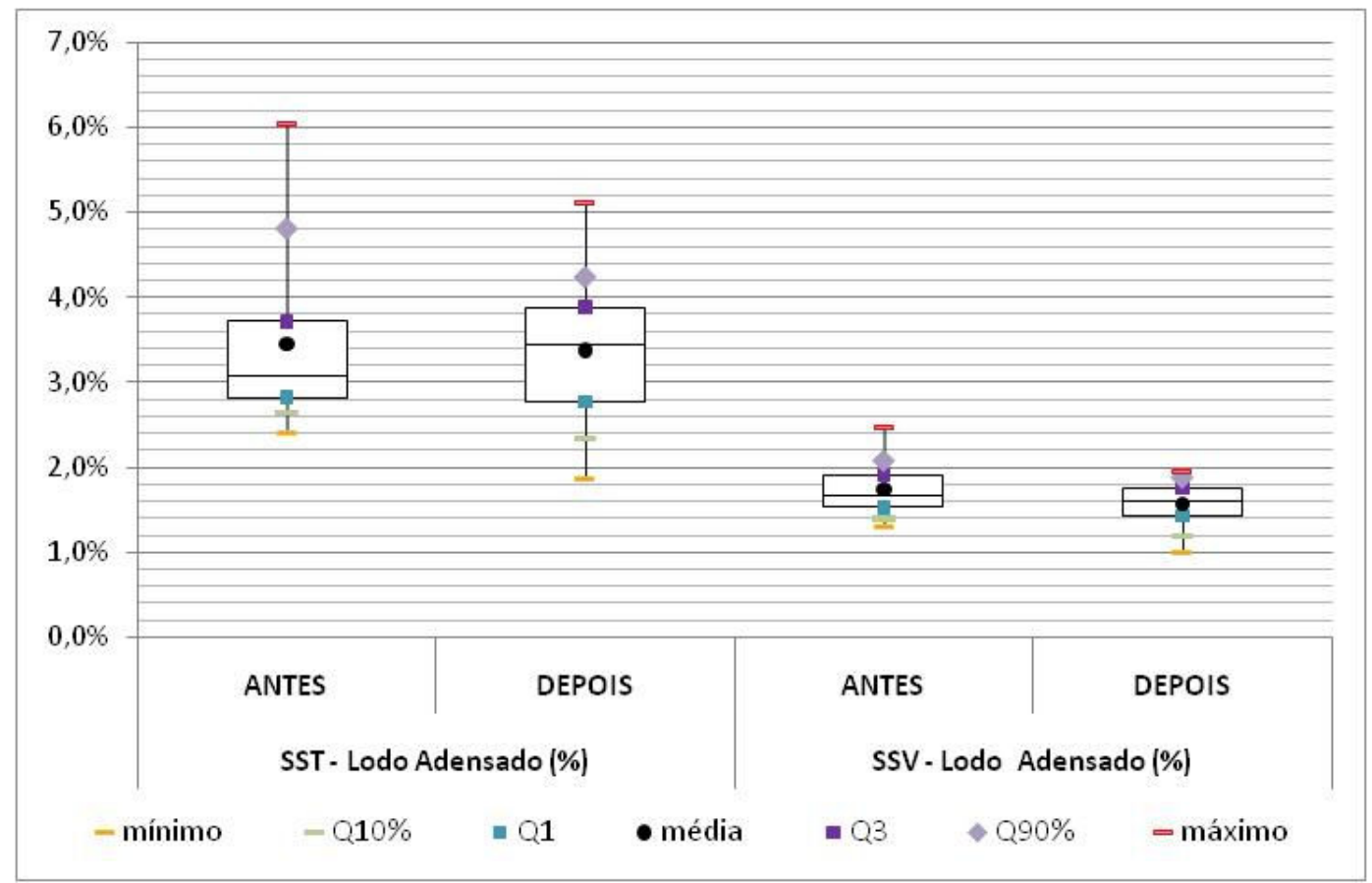

Figura 72 - SST e SSV no Lodo Adensado nos Adensadores por Gravidade (\%).

Verifica-se que o teor de sólidos no lodo adensado (em torno de 3,5\%) mantém-se substancialmente menor que o valor de projeto $(7,5 \%)$ em ambos os períodos valor este que pode ser considerado otimista para a tecnologia empregada. Além 
disso, nota-se um aumento na vazão líquida de lodo adensado (Figura 73), mas que, pela magnitude dos valores, não indica grandes impactos para as unidades posteriores de digestão, como será discutido no item a seguir.

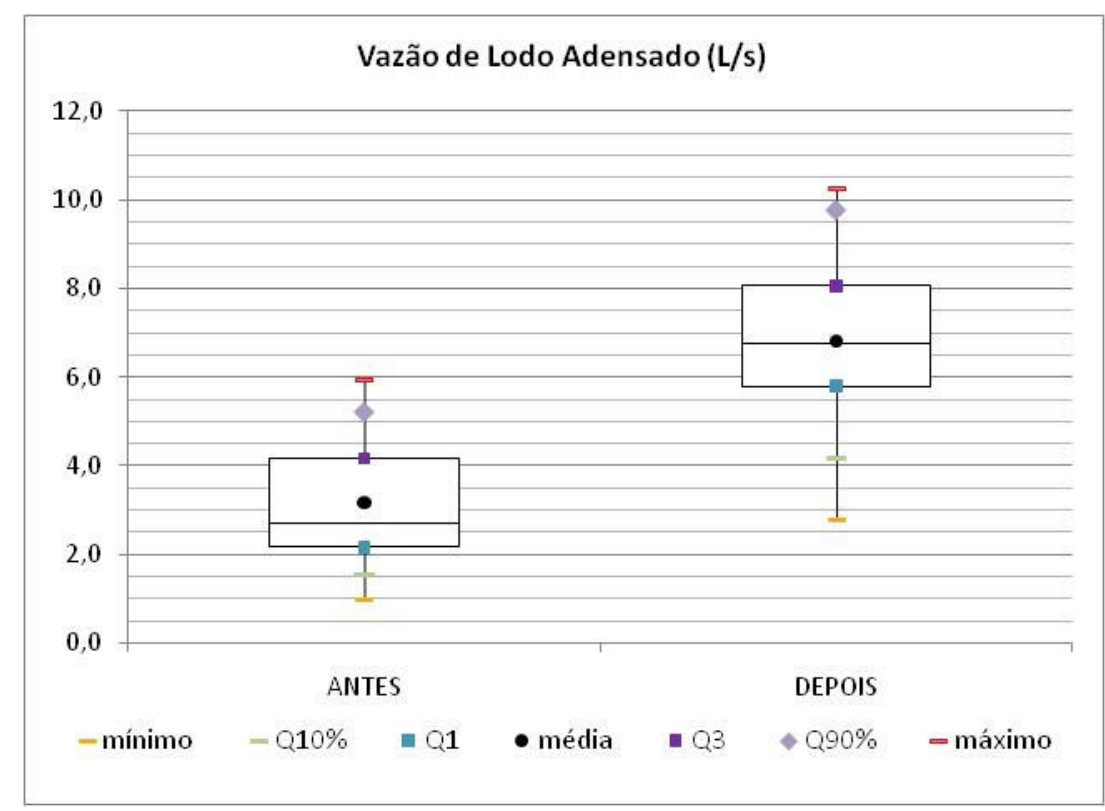

Figura 73 - Vazão de Lodo Adensado nos adensadores por gravidade (L/s).

\subsubsection{Tanque de Aeração e Decantador Secundário}

Os tanques de aeração são, em conjunto com os decantadores secundários, os principais componentes do tratamento biológico via lodos ativados. São nestes tanques que ocorre o consumo de matéria orgânica pela microbiota aeróbia, a qual cresce e se multiplica, gerando o lodo, que por sua vez é separado da fase líquida nos decantadores secundários, sendo então a maior parcela recirculada para os tanques de aeração e uma parcela menor descartada do sistema, para o tratamento de fase sólida.

Como parâmetros operacionais de importância para os tanques de aeração têm-se (METCALF e EDDY, 2003; VAN HAANDEL e MARAIS, 1999; VON SPERLING, 2002):

- Concentrações de SST e SSV: indicam a quantidade de biomassa no interior dos reatores, responsável pelo consumo da matéria orgânica. Valores de referência para estas concentrações em sistemas de lodos ativados convencional estão na faixa de 1.500 a $4.000 \mathrm{mg} / \mathrm{L}$ para SSV; 
- Relação A/M (alimento/microrganismo): razão entre a DBO aplicada aos tanques e a quantidade de sólidos nos mesmos, significando a disponibilidade de alimento para os microrganismos responsáveis pelo tratamento. A literatura indica valores na faixa de 0,2 a 0,6 kg DBO/kg SSV.dia;

- Idade do lodo: representa o tempo de detenção da biomassa no sistema, uma vez que esta é recirculada a partir dos decantadores secundários subsequentes. É calculada como a razão entre a quantidade de biomassa presente no sistema e a quantidade descartada para o tratamento de fase sólida. Lodos ativados convencionais operam com idade do lodo da ordem de 3 a 15 dias;

- Índice volumétrico do lodo (IVL): é o volume em mililitros ocupado por um grama de lodo, após sedimentação de 30 minutos. Valores acima de 150 $\mathrm{mL} / \mathrm{g}$ indicam lodo com sedimentabilidade comprometida, ocasionando separação deficiente da fase sólida nos decantadores secundários.

No período de estudo a ETE ABC operou praticamente sempre apenas um dos 4 tanques de aeração equipados, com exceção de fevereiro e março de 2008 , em que operou com dois tanques. Isto representa um volume de $17.595 \mathrm{~m}^{3}$ (HIDROSERVICE, 1998). Na Tabela 12 abaixo são apresentados os valores dos diversos parâmetros operacionais de interesse, os quais apresentaram variações entre os períodos controle e com lodo dentro das faixas de valores indicados em literatura.

Tabela 12 - Variáveis e Parâmetros Operacionais monitorados nos Tanques de Aeração períodos controle e com lodo.

\begin{tabular}{ccccccccccc}
\hline Parâmetro & Período & $\mathbf{n}$ & média & $\mathbf{\pm}$ & desvio & mediana & mín. & máx. & $\begin{array}{c}\text { coef. } \\
\text { var. }\end{array}$ \\
\hline SST & Controle & 23 & 3.583 & \pm & 892 & 3.234 & 2.486 & 5.663 & $25 \%$ \\
(mg/L) & Com lodo & 15 & 4.164 & \pm & 1.313 & 3.835 & 2.231 & 6.835 & $32 \%$ \\
SSV & Controle & 23 & 2.414 & \pm & 593 & 2.205 & 1.732 & 3.836 & $25 \%$ \\
(mg/L) & Com lodo & 15 & 2.643 & \pm & 800 & 2.368 & 1.602 & 4.413 & $30 \%$ \\
Idade do lodo & Controle & 24 & 4,3 & \pm & 0,4 & 4 & 4 & 5 & $10 \%$ \\
(dias) & Com lodo & 15 & 4,2 & \pm & 0,4 & 4 & 4 & 5 & $9 \%$ \\
Relação A/M & Controle & 24 & 0,33 & \pm & 0,08 & 0,32 & 0,21 & 0,54 & $24 \%$ \\
(kg DBO/kg & Com lodo & 15 & 0,51 & \pm & 0,15 & 0,47 & 0,35 & 0,84 & $28 \%$ \\
SSV.dia) & Controle & 24 & 68 & \pm & 23 & 62 & 45 & 138 & $34 \%$ \\
IVL (mL/g) & Com lodo & 14 & 117 & \pm & 40 & 125 & 55 & 178 & $34 \%$ \\
\hline
\end{tabular}


De modo geral, a ETE ABC operou no período com lodo com:

- Aumento na concentração de sólidos em relação ao período controle: de $3.500 \mathrm{mg} / \mathrm{L}$ para $4.300 \mathrm{mg} / \mathrm{L}$ de SST (Figura 74). A relação SSV/SST observada se manteve da ordem de $65 \%$, abaixo do valor esperado em projeto, de $75 \%$ (HIDROSERVICE, 1998);

- Relação A/M: aumentou de 0,32 kg DBO/kg SSV.dia no período controle para $0,52 \mathrm{~kg} \mathrm{DBO} / \mathrm{kg} \mathrm{SSV}$.dia no período com lodo, ocasionado pelo maior aumento percentual na concentração de DBO no efluente primário (Tabela 9) em relação ao aumento da concentração de sólidos no tanque de aeração (Tabela 12);

- Idade do Lodo manteve-se praticamente a mesma nos dois períodos;

- IVL sempre abaixo de $150 \mathrm{~mL} / \mathrm{g}$, mesmo após o aumento ocorrido no período com lodo da ETA - de $70 \mathrm{~mL} / \mathrm{g}$ para $120 \mathrm{~mL} / \mathrm{g}$ (Figura 75) - de modo que não houve indícios de problemas na sedimentabilidade do lodo. Tal situação, mesmo sendo favorável, vai contra os valores obtidos em outros estudos (ASADA, 2007; AWWA, 1996).

Assim, observa-se que o tratamento biológico se manteve estável, mesmo após o lançamento do lodo da ETA Rio Grande na ETE ABC. Isto se reflete na qualidade do efluente final que, conforme apresentado no item 5.2, manteve-se praticamente inalterada para a maioria das variáveis monitoradas (com exceção do fósforo, que apresentou melhorias). Uma justificativa plausível para isto é o fato de a remoção do lodo adicionado da ETA ocorrer em grande parte já nos decantadores primários da ETE, de modo que sua influência nas etapas subsequentes do tratamento de fase líquida não é significativa. 


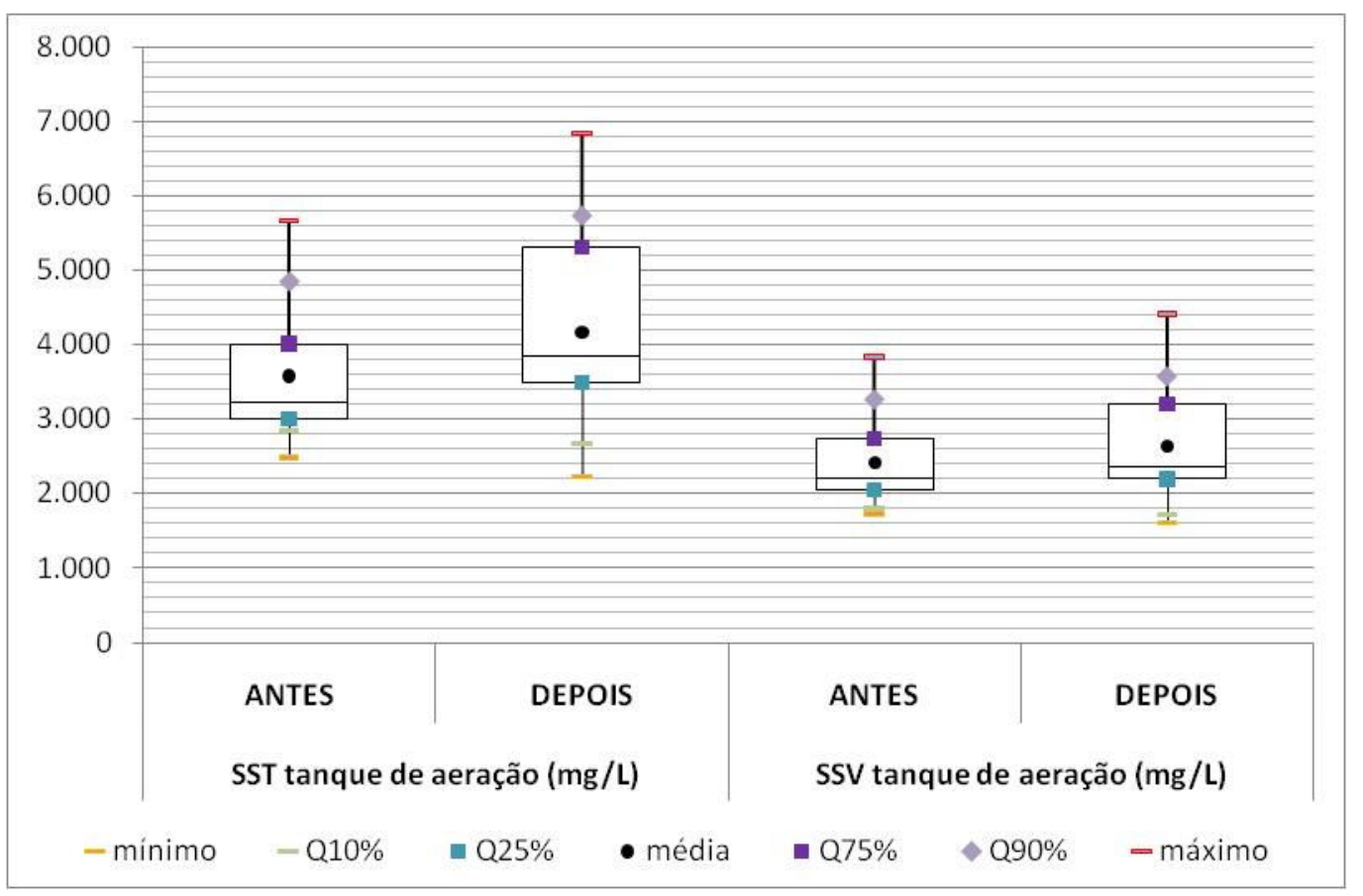

Figura 74 - SST e SSV nos Tanques de Aeração (mg/L).

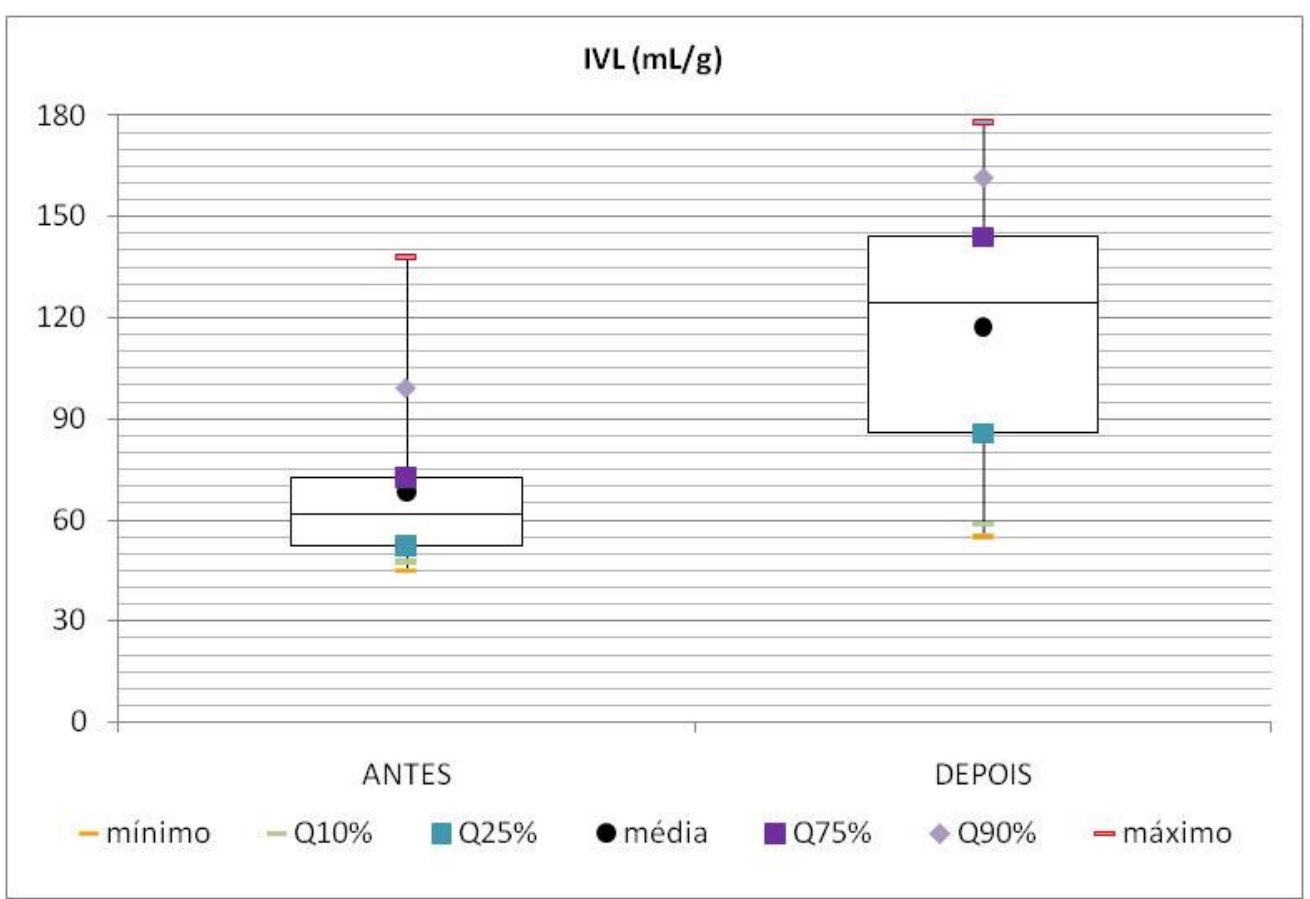

Figura 75 - Índice Volumétrico do Lodo nos Tanques de Aeração (mL/g).

No tocante aos decantadores secundários, os parâmetros operacionais analisados são as taxas de aplicação superficial (TAS - medida em $\mathrm{m}^{3} / \mathrm{m}^{2}$.dia) e de aplicação de sólidos (TASol - em kg/m².d). A Norma NBR 12.209 recomenda recomendada valores de TAS abaixo de $24 \mathrm{~m}^{3} / \mathrm{m}^{2}$.dia, calculada para a vazão média e 
considerando concentrações de SST no tanque de aeração entre 3,0 e 4,5 g/L (ABNT, 1992).

Para a TASol, a mesma Norma (ABNT, 1992) indica como valor máximo 144 $\mathrm{kg} / \mathrm{m}^{2}$.dia, calculada como a razão entre a quantidade de sólidos afluente aos decantadores secundários (considerando a soma da vazão média afluente à ETE e da vazão de retorno de lodo) e a área total de decantação em uso. Valores maiores que o recomendado favorecem o arraste de sólidos para o efluente final, prejudicando sua qualidade.

A ETE ABC operou em praticamente todos os meses com 4 unidades de decantação secundária no período controle, salvo em maio e dezembro de 2006, quando operou com apenas 3 decantadores. Cada unidade corresponde a um decantador circular, com 46 metros de diâmetro, resultando em uma área total de $6.644 \mathrm{~m}^{2}$. No período com lodo, variou-se a quantidade de decantadores em uso de 3 a 5 unidades (HIDROSERVICE, 1998).

A Tabela 13 abaixo apresenta os valores das referidas taxas, em ambos os períodos estudados. A partir dela, observa-se que as taxas de aplicação superficial encontraram-se na faixa de operação indicada na norma, tanto no período controle quanto com lodo. Porém, houve valores máximos acima dos $24 \mathrm{~m}^{3} / \mathrm{m}^{2}$. dia, os quais ocorreram em meses em que se operou com 3 decantadores apenas.

No que se refere à taxa de aplicação de sólidos, mesmo nos meses mais críticos, esta se manteve abaixo dos $144 \mathrm{~kg} / \mathrm{m}^{2}$.dia em ambos os períodos, não ocorrendo prejuízo na qualidade do efluente final, conforme se observou no item 5.2.

Tabela 13 - Parâmetros Operacionais monitorados nos Decantadores Secundários - períodos controle e com lodo.

\begin{tabular}{cccrllcccc}
\hline Parâmetro & Período & $\mathbf{n}$ & média & \pm & desvio & mediana & mín. & máx. & coef. var. \\
\hline TAS & Controle & 24 & 18 & \pm 2 & 17 & 15 & 25 & $13 \%$ \\
$\left(\mathrm{~m}^{3} / \mathrm{m}^{2}\right.$.dia $)$ & Com lodo & 15 & 21 & \pm 4 & 20 & 15 & 27 & $21 \%$ \\
TASol & Controle & 24 & 66 & \pm 19 & 59 & 41 & 114 & $29 \%$ \\
$\left(\mathrm{~kg} / \mathrm{m}^{2} . \mathrm{dia}\right)$ & Com lodo & 15 & 83 & \pm 19 & 81 & 51 & 117 & $23 \%$ \\
\hline
\end{tabular}

Em relação ao lodo separado nos decantadores secundários, do qual a maior parcela é recirculada e o restante é descartado para a linha de tratamento de fase 
sólida, têm-se os seguintes valores, reunidos na Tabela 14 abaixo e representados graficamente nos box-plot das Figura 76, Figura 77 e Figura 78:

Tabela 14 - Variáveis monitoradas no Lodo Secundário - períodos controle e com lodo.

\begin{tabular}{|c|c|c|c|c|c|c|c|c|c|}
\hline Parâmetro & Período & $\mathrm{n}$ & média & \pm & desvio & mediana & mín. & máx. & $\begin{array}{l}\text { coef } \\
\text { var. }\end{array}$ \\
\hline \multirow{2}{*}{$\begin{array}{l}\text { Vazão de Lodo } \\
\text { Recirculado } \\
\text { (L/s) }\end{array}$} & Controle & 24 & 1.145 & \pm & 81 & 1.149 & 1.021 & 1.282 & $7 \%$ \\
\hline & Com lodo & 15 & 1.299 & \pm & 101 & 1.324 & 1.137 & 1.453 & $8 \%$ \\
\hline \multirow{2}{*}{$\begin{array}{l}\text { Vazão de Lodo } \\
\text { Descartado } \\
\text { (L/s) }\end{array}$} & Controle & 24 & 22,59 & \pm & 2,88 & 22,90 & 16,00 & 27,00 & $13 \%$ \\
\hline & Com lodo & 14 & 25,24 & \pm & 3,08 & 25,30 & 21,00 & 29,14 & $12 \%$ \\
\hline \multirow{2}{*}{$\begin{array}{l}\text { SST - Lodo } \\
\text { Secundário } \\
\text { (mg/L) }\end{array}$} & Controle & 23 & 6.994 & \pm & 2.084 & 6.398 & 3.740 & 11.284 & $30 \%$ \\
\hline & Com lodo & 15 & 7.388 & \pm & 2.052 & 7.474 & 4.142 & 11.285 & $28 \%$ \\
\hline \multirow{2}{*}{$\begin{array}{l}\text { SSV - Lodo } \\
\text { Secundário } \\
\text { (mg/L) }\end{array}$} & Controle & 23 & 4.739 & \pm & 1.376 & 4.328 & 2.852 & 8.021 & $29 \%$ \\
\hline & Com lodo & 15 & 4.696 & \pm & 1.220 & 4.649 & 2.992 & 7.253 & $26 \%$ \\
\hline
\end{tabular}

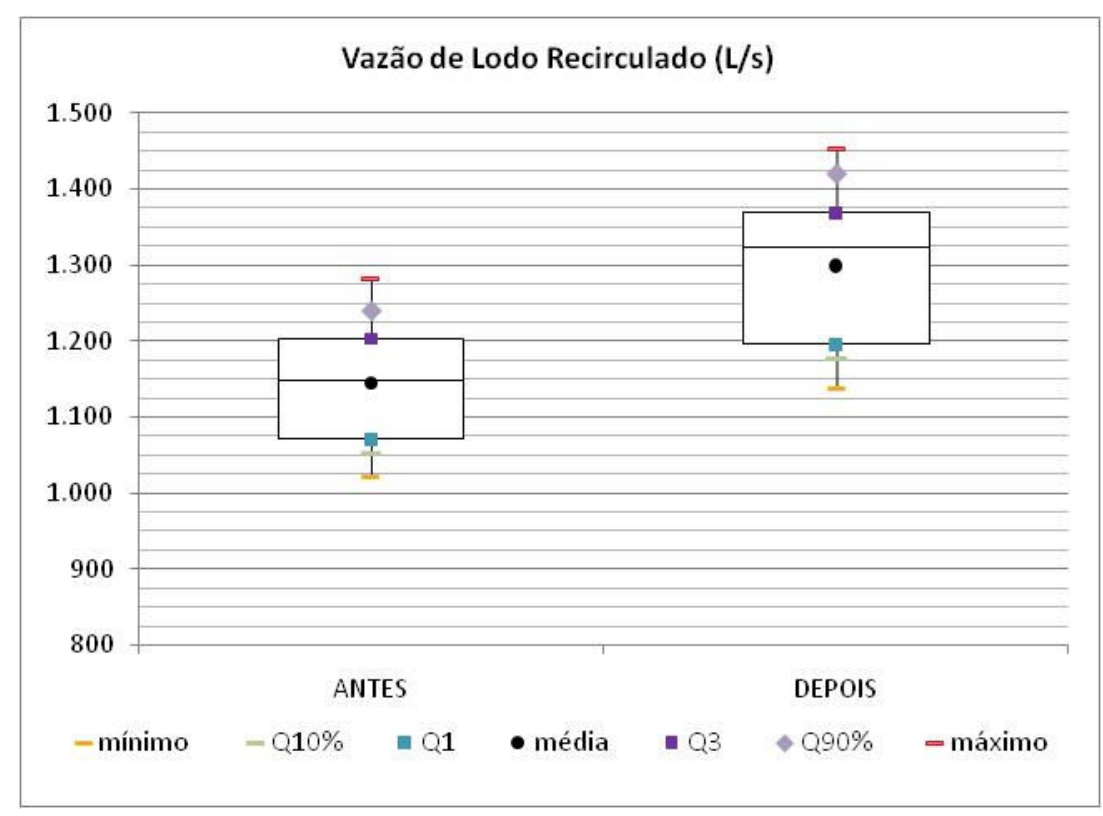

Figura 76 - Vazão de Lodo Recirculado (L/s). 


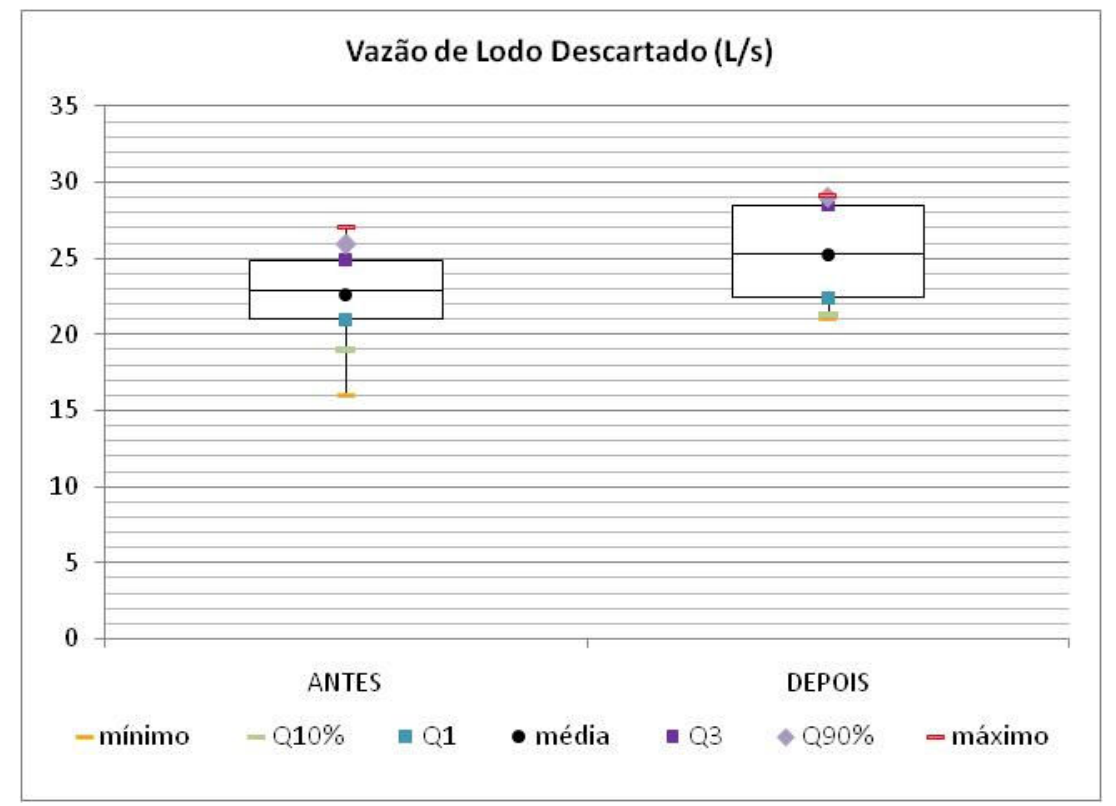

Figura 77 - Vazão de Lodo Descartado (L/s).

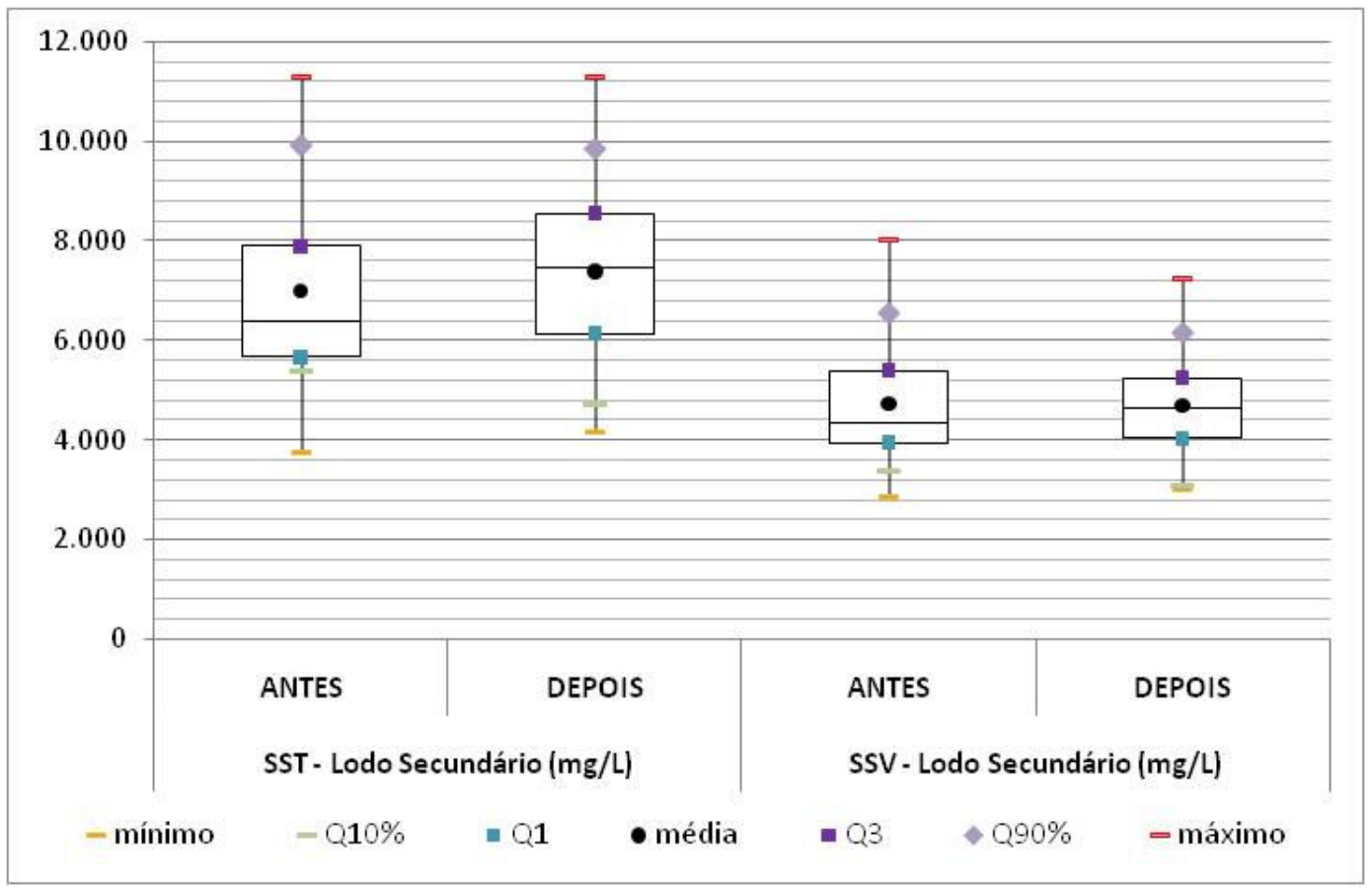

Figura 78 - SST e SSV no Lodo Secundário (mg/L).

A partir destes valores, nota-se que houve um aumento na vazão volumétrica de reciclo de lodo secundário, biológico, passando de $1,15 \mathrm{~m}^{3} / \mathrm{s}$ no período controle para $1,30 \mathrm{~m}^{3} / \mathrm{s}$ em média no período com lodo da ETA. Em termos de taxa de recirculação, porém, esta se manteve (em torno de $80 \%$ ), uma vez que a vazão afluente à ETE também sofreu aumento no período com lodo. 
Como a concentração de sólidos no lodo permaneceu praticamente inalterada nos dois períodos, tal aumento de retorno de lodo tem como consequência uma maior concentração de sólidos nos tanques de aeração, conforme apresentado na Figura 74. Este aumento também ocorreu, porém de forma mais sutil, na vazão de lodo descartada, de 22 L/s para 25 L/s (Figura 77). Com isso, espera-se que não ocorra prejuízos nas unidades de adensamento de lodo secundário, isto é, nos flotadores, analisados a seguir.

\subsubsection{Adensadores por Flotação}

Os adensadores por flotação são responsáveis pelo aumento da concentração de sólidos do lodo biológico removido dos decantadores secundários, com consequente diminuição de volume. Na ETE $A B C$, durante os períodos estudados foi utilizado apenas um tanque circular para flotação de lodo, com 14,0 m de diâmetro (153 m² de área), profundidade média de 3,0 $\mathrm{m}$ e remoção mecânica do lodo flotado. $\mathrm{O}$ teor de sólidos esperado no lodo flotado é da ordem de 4\% (HIDROSERVICE, 1998).

O parâmetro operacional monitorado na unidade de flotação refere-se à TASol, cujos valores de referência encontrados na literatura a situam entre 58 e $96 \mathrm{~kg} \mathrm{SST} / \mathrm{m}^{3}$.dia (METCALF \& EDDY, 2003), ou 50 a $220 \mathrm{~kg} \mathrm{ST} / \mathrm{m}^{2}$.dia (ANDREOLI et al, 2001).

O que se observou nos períodos estudados, conforme dados da Tabela 15 abaixo, é que a operação no flotador de lodo não sofreu grandes alterações entre os períodos controle e com lodo. Com o aumento da carga de sólidos afluente aos adensadores no período com lodo, a TASol apresentou valores acima porém não muito distantes da faixa indicada na literatura, de modo que não se pode afirmar que ocorreram prejuízos no processo de adensamento do lodo.

A concentração de sólidos no lodo flotado inclusive apresentou também ligeiro aumento (Figura 79), com consequente menor produção em volume (Figura 80), sendo esta mais estável se quando comparada com os valores no período controle. 
Tabela 15 - Variáveis e Parâmetros Operacionais monitorados nos Flotadores - períodos controle e com lodo.

\begin{tabular}{|c|c|c|c|c|c|c|c|c|c|}
\hline Parâmetro & Período & $\mathbf{n}$ & média & \pm & desvio & mediana & mín. & máx. & $\begin{array}{l}\text { coef. } \\
\text { var. }\end{array}$ \\
\hline \multirow{2}{*}{$\begin{array}{l}\text { Vazão afluente } \\
(\mathrm{L} / \mathrm{s})\end{array}$} & Controle & 24 & 22,59 & \pm & 2,88 & 22,90 & 16,00 & 27,00 & $13 \%$ \\
\hline & Com lodo & 14 & 25,24 & \pm & 3,08 & 25,30 & 21,00 & 29,14 & $12 \%$ \\
\hline \multirow{2}{*}{$\begin{array}{c}\text { SST - Lodo } \\
\text { Biológico }(\mathrm{mg} / \mathrm{L})\end{array}$} & Controle & 23 & 6.994 & \pm & 2.084 & 6.398 & 3.740 & 11.284 & $30 \%$ \\
\hline & Com lodo & 15 & 7.388 & \pm & 2.052 & 7.474 & 4.142 & 11.285 & $28 \%$ \\
\hline \multirow{2}{*}{ TASol (kg/m³.dia) } & Controle & 23 & 90 & \pm & 33 & 78 & 57 & 167 & $36 \%$ \\
\hline & Com lodo & 14 & 109 & \pm & 38 & 104 & 49 & 185 & $34 \%$ \\
\hline \multirow{2}{*}{$\begin{array}{l}\text { Vazão de Lodo } \\
\text { Flotado (L/s) }\end{array}$} & Controle & 24 & 1,96 & \pm & 1,40 & 1,60 & 0,00 & 4,37 & $71 \%$ \\
\hline & Com lodo & 15 & 1,18 & \pm & 0,95 & 0,73 & 0,50 & 3,66 & $80 \%$ \\
\hline \multirow{2}{*}{$\begin{array}{l}\text { SST - Lodo } \\
\text { Flotado (\%) }\end{array}$} & Controle & 20 & 2,3 & \pm & 0,3 & 2,3 & 1,7 & 2,8 & $14 \%$ \\
\hline & Com lodo & 14 & 2,5 & \pm & 0,6 & 2,5 & 1,4 & 3,1 & $22 \%$ \\
\hline \multirow{2}{*}{$\begin{array}{l}\text { SSV - Lodo } \\
\text { Flotado (\%) }\end{array}$} & Controle & 20 & 1,6 & \pm & 0,3 & 1,6 & 1,0 & 2,0 & $19 \%$ \\
\hline & Com lodo & 14 & 1,6 & \pm & 0,4 & 1,7 & 0,9 & 2,2 & $22 \%$ \\
\hline
\end{tabular}

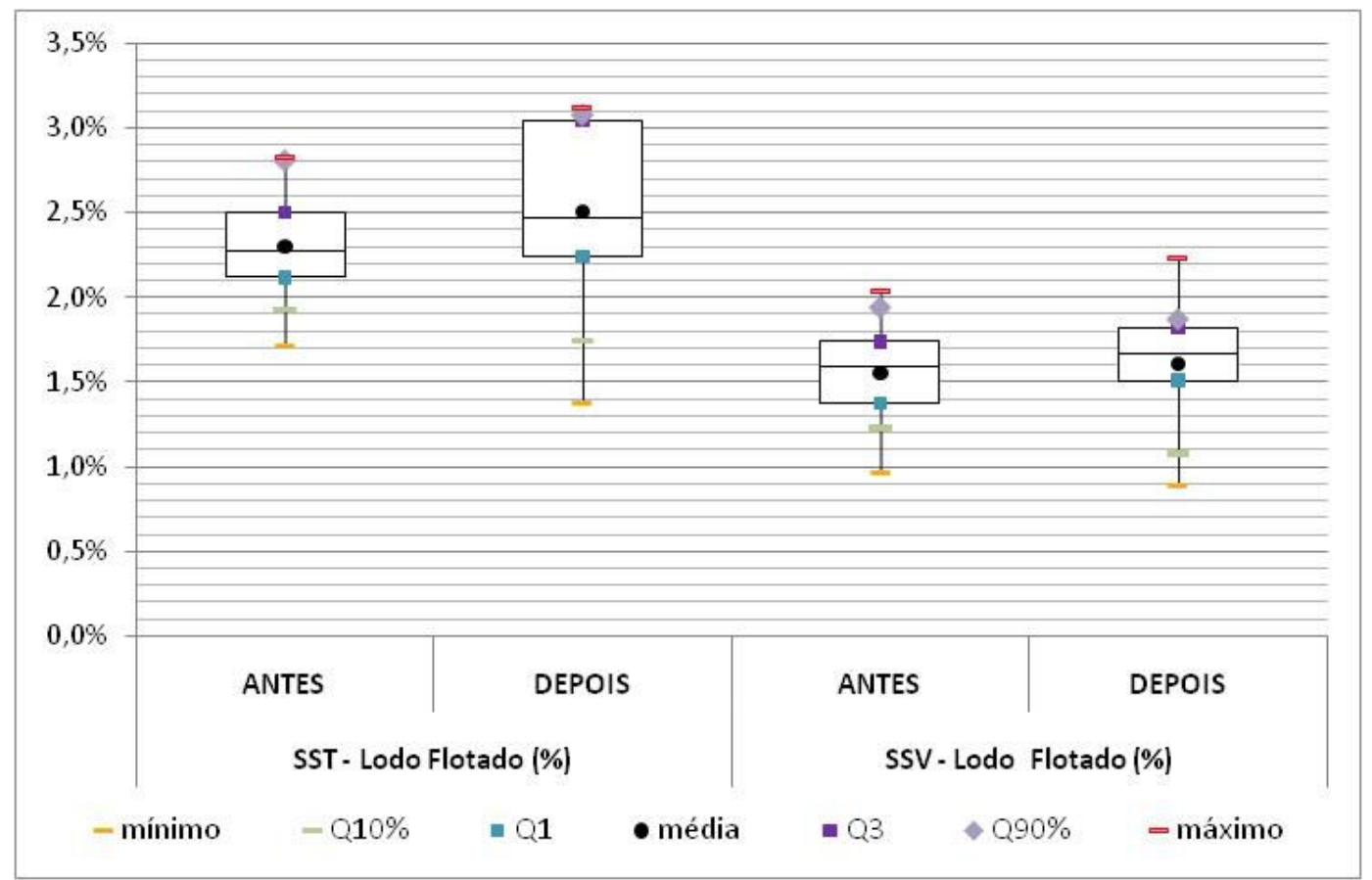

Figura 79 - SST e SSV no Lodo Flotado (\%). 


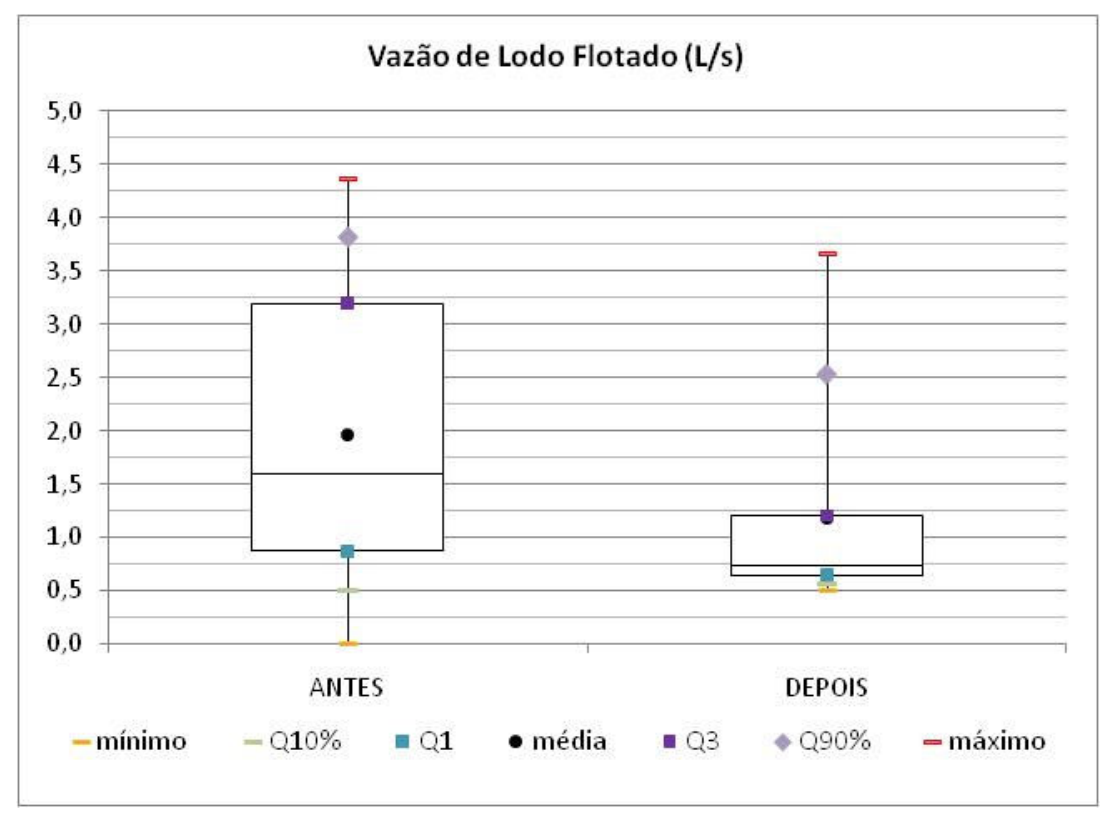

Figura 80 - Vazão de Lodo Flotado (L/s).

\subsubsection{Digestores}

Uma vez adensado, tanto o lodo primário quanto o secundário devem ser estabilizados, processo este que ocorre nos digestores anaeróbios, gerando gás metano, o qual é acumulado em um gasômetro e é ou posteriormente utilizado nas caldeiras do sistema de aquecimento de lodo ou queimado (excedente). Valores típicos de produção de gás situam-se na faixa de 0,75 a $1,12 \mathrm{~m}^{3}$ de gás/kg de SV removido (METCALF \& EDDY, 2003).

Prevê-se em projeto uma redução de $50 \%$ na concentração de sólidos voláteis pósdigestão do lodo. Para tal, como critérios de dimensionamento, adotou-se tempo de detenção total de 30 dias. Nos períodos estudados, a ETE ABC operou dois digestores, cada um com volume de $10.520 \mathrm{~m}^{3}$ (HIDROSERVICE, 1998).

A Tabela 16 abaixo reúne os valores em cada período de cada uma das variáveis operacionais de interesse desta unidade. No cálculo da eficiência de remoção de SV, o monitoramento da ETE considerou como concentração afluente uma ponderação entre as vazões de lodos adensados por gravidade e por flotação: 
Tabela 16 - Variáveis e Parâmetros Operacionais dos Digestores - períodos controle e com lodo.

\begin{tabular}{ccccccccc}
\hline Parâmetro & Período & $\mathbf{n}$ & média & \pm desvio & mediana & mín. & máx. & $\begin{array}{c}\text { Coef. } \\
\text { Var. }\end{array}$ \\
\hline Vazão afluente & Controle & 24 & 5,1 & $\pm 1,3$ & 5,2 & 1,8 & 7,1 & $25 \%$ \\
(L/s) & Com lodo & 15 & 8,0 & $\pm 1,8$ & 7,9 & 5,5 & 11,2 & $22 \%$ \\
Tempo de & Controle & 23 & 48 & \pm 11 & 45,4 & 34,3 & 71,6 & $22 \%$ \\
Detenção (dias) & Com lodo & 15 & 32 & \pm 7 & 30,7 & 21,7 & 44,0 & $21 \%$ \\
Produção de Gás & Controle & 21 & $1.759 \pm 702$ & 1.632 & 645 & 3.273 & $40 \%$ \\
(m³/dia) & Com lodo & 15 & 2.998 & \pm 1.121 & 2.617 & 1.726 & 5.457 & $37 \%$ \\
Vazão Lodo & Controle & 24 & $3,20 \pm 0,94$ & 3,30 & 1,80 & 4,61 & $29 \%$ \\
Digerido (L/s) & Com lodo & 14 & $5,20 \pm 1,36$ & 5,45 & 1,67 & 6,66 & $26 \%$ \\
ST lodo digerido & Controle & 23 & $3,7 \pm 0,3$ & 3,7 & 3,1 & 4,5 & $9 \%$ \\
(\%) & Com lodo & 15 & $3,6 \pm 0,6$ & 3,6 & 2,6 & 4,5 & $17 \%$ \\
SV lodo digerido & Controle & 23 & $1,9 \pm 0,2$ & 1,9 & 1,4 & 2,1 & $9 \%$ \\
(\%) & Com lodo & 15 & $1,8 \pm 0,2$ & 1,8 & 1,4 & 2,2 & $12 \%$ \\
Remoção de SV & Controle & 24 & $12,3 \pm 10,6$ & 13,4 & $-16,2$ & 32,0 & $86 \%$ \\
(\%) & Com lodo & 15 & $17,2 \pm 6,7$ & 15,2 & 5,4 & 28,3 & $39 \%$ \\
\hline
\end{tabular}

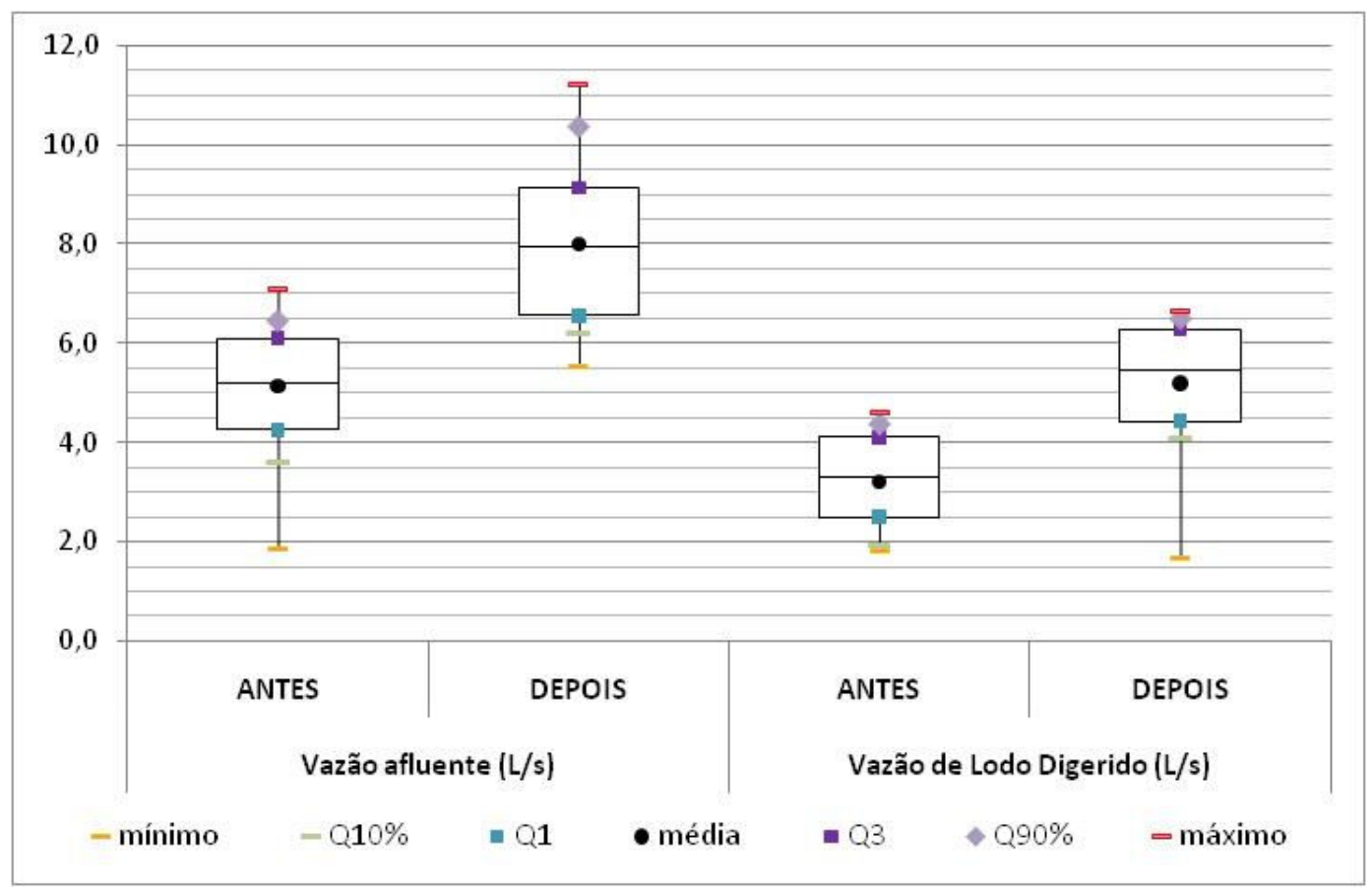

Figura 81 - Vazão de lodo afluente e efluente dos Digestores (L/s). 


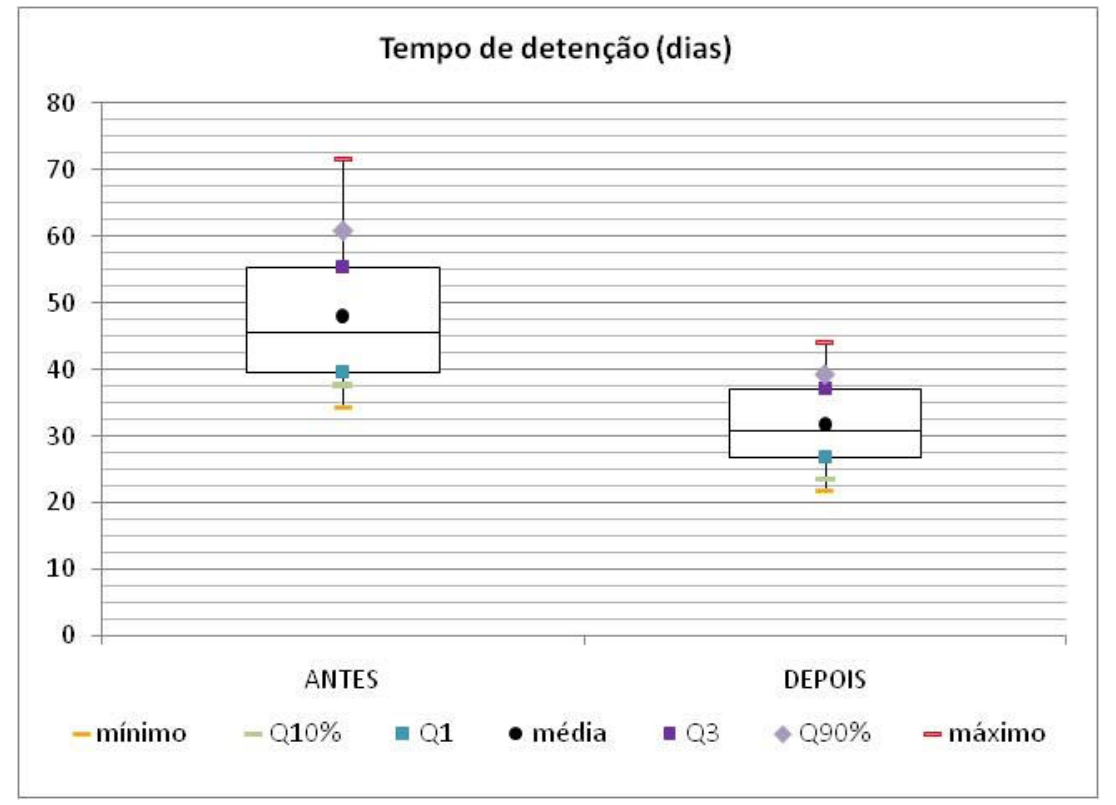

Figura 82 - Tempo de detenção nos Digestores (dias).

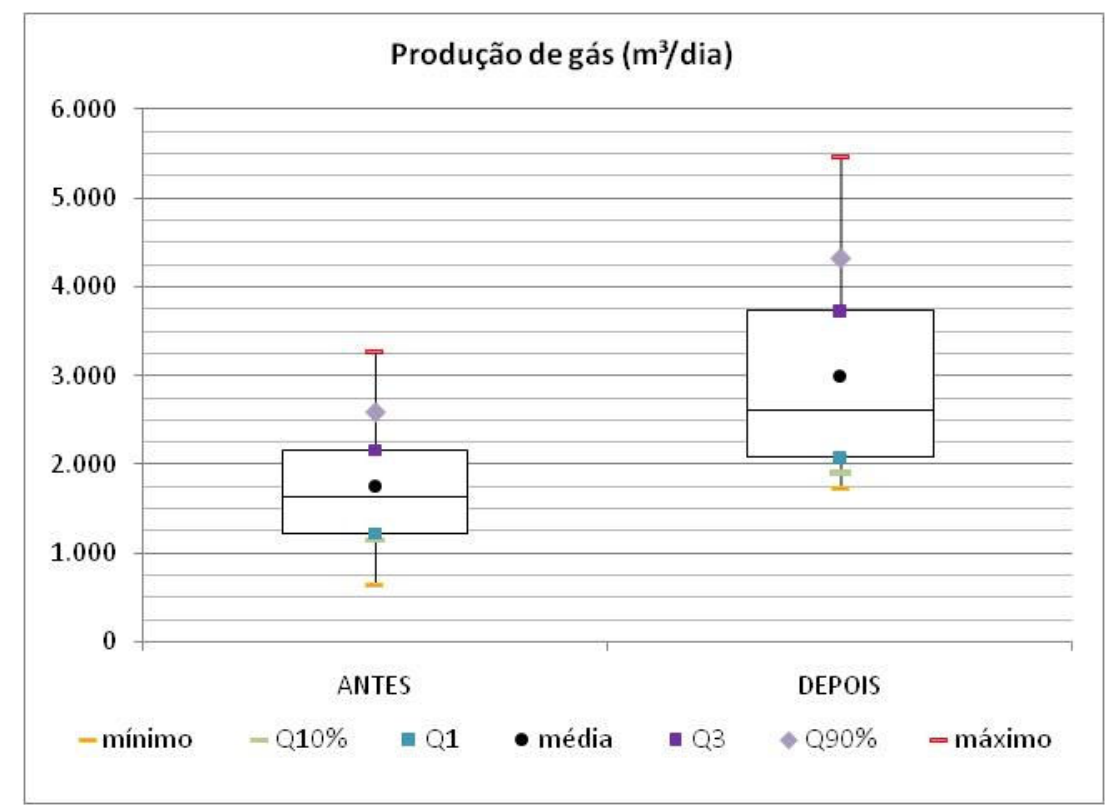

Figura 83 - Produção de Gás nos Digestores (m³/dia). 


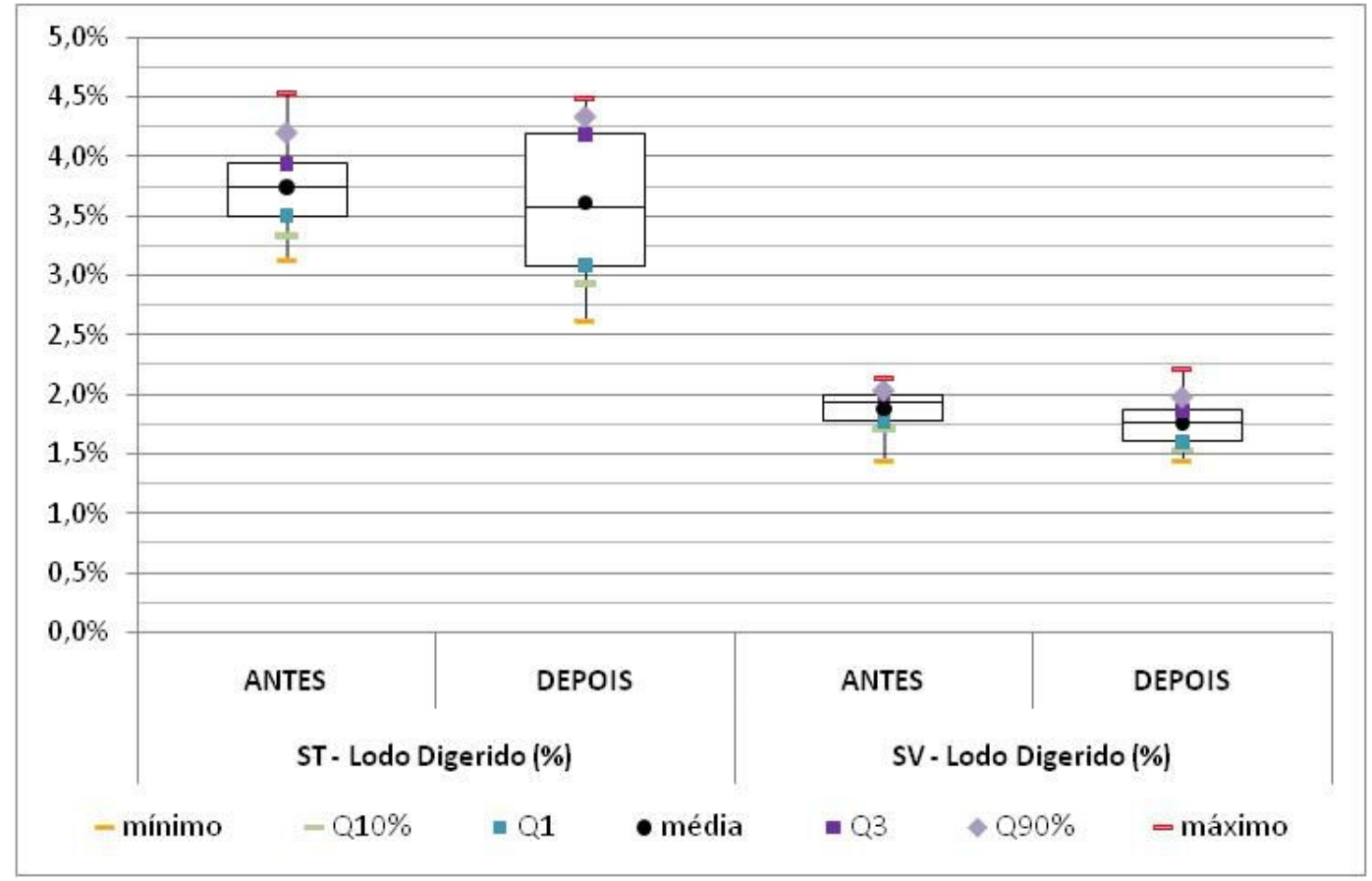

Figura 84 - ST e SV no Lodo Digerido (\%).

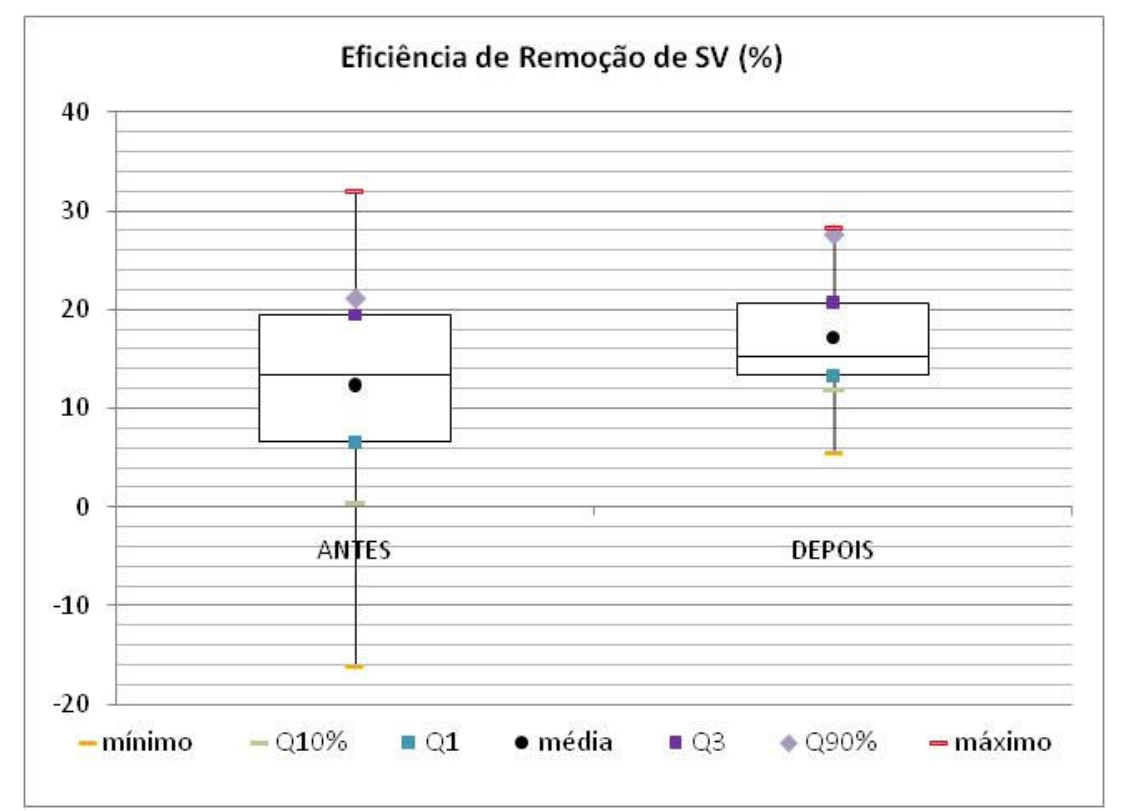

Figura 85 - Eficiência de remoção de SV nos Digestores da ETE ABC. 


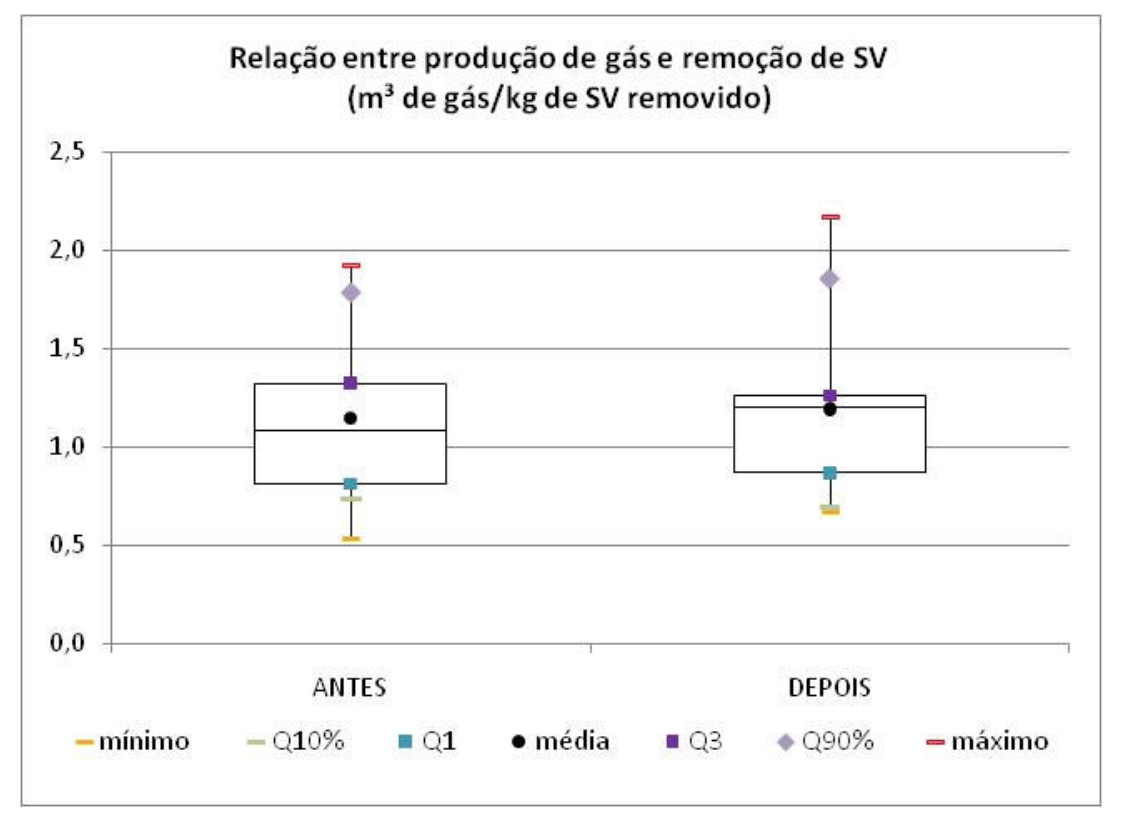

Figura 86 - Relação entre geração de gás e remoção de SV nos Digestores da ETE ABC.

A partir destes dados, constata-se que no período com lodo:

- Com o aumento da vazão afluente aos digestores no período com lodo (Figura 81), ocorreu diminuição no tempo de detenção de 48 dias para 32 dias (Figura 82), porém este ainda permaneceu acima do tempo de projeto de 30 dias;

- O aumento de vazão de lodo afluente resultou também em maior vazão de lodo digerido, destinado ao condicionamento e desidratação (Figura 81). É interessante notar que o balanço de vazões não fecha, uma vez que a afluente é maior que a efluente;

- Mesmo com a diminuição da detenção, no período com lodo ocorreram melhorias no processo de estabilização de lodo da ETE, uma vez que a aumentou-se significativamente a produção de biogás - de em torno de 1.760 $\mathrm{m}^{3} /$ dia para próximo de $3.000 \mathrm{~m}^{3} /$ dia (Figura 83). Também, a eficiência de remoção de SV se mostrou mais estável (Figura 84 e Figura 85) - embora ainda tenha se mantido muito abaixo dos 50\% esperados -, podendo o mesmo ser dito para a relação geração de gás por remoção de SV (Figura 86), no período com lodo quando comparado com o período controle.

Não se observou, portanto, a ocorrência de qualquer processo inibitório, conforme alertado por AWWA (1996), Bueno et al. (2007) e Scalize (2003), mesmo havendo 
adição de sulfato com o lodo da ETA (o qual no ambiente anaeróbio do digestor é reduzido a sulfeto).

\subsubsection{Condicionamento e Desidratação}

Como etapa final no tratamento de fase sólida na ETE ABC, ocorre o processo de desidratação mecânica do lodo, em filtros-prensa, de modo a se atingir maiores teores de sólidos (e consequentemente, menores quantidades volumétricas de lodo). Com isso, torna-se o lodo apto para transporte a sua destinação final.

A fim de se garantir a maior eficiência possível dos equipamentos mecânicos de desidratação, previamente é realizado um condicionamento químico do lodo, através da adição de produtos químicos. Indicam-se dosagens na faixa de 40 a $100 \mathrm{~kg}$ de $\mathrm{FeCl}_{3} / \mathrm{t}$ de lodo e de 110 a $300 \mathrm{~kg}$ de cal/t de lodo, quando a desidratação posterior é realizada em filtros-prensa (ANDREOLI et al., 2001).

Após o condicionamento, o lodo é desidratado nos filtros-prensa, atingindo teor de sólidos de 40\%, segundo valores de projeto da ETE ABC (HIDROSERVICE, 1998).

\section{A}

Tabela 17 abaixo apresenta os valores observados de consumo de produtos químicos no condicionamento do lodo, bem como do teor de sólidos resultante e a produção final de lodo, enviada à disposição final, em ambos os períodos de estudo. Por estes valores, nota-se que:

- Com o aumento da vazão de lodo afluente ao condicionamento (efluente dos digestores) no período com lodo, houve maior consumo de produtos químicos, principalmente de cal, cujo aumento foi de mais de 100\% (Figura 87 e Figura 88). Não se observou, portanto, a diminuição de consumo de coagulante conforme indicada por Babatunde e Zhao (2007);

- Pela mesma razão, a produção final de lodo na ETE ABC, medida em carga de sólidos (kg/dia) apresentou aumento no período com lodo de $50 \%$ em média (Figura 89). Parte deste aumento justifica-se também pelo crescimento gradual da vazão afluente à ETE ao longo dos períodos estudados (conforme apresentado no item 5.2), o que significou também aumento gradual na carga de sólidos afluente à ETE; 
- O teor de sólidos no lodo manteve-se, nos dois períodos analisados, em torno de $35 \%$, condizente com a eficiência esperada de filtros-prensa (Figura 90). No período com lodo, a variabilidade desta variável foi maior que no período controle.

Tabela 17 - Variáveis e Parâmetros Operacionais monitorados no Condicionamento e na Desidratação do lodo na ETE ABC - períodos controle e com lodo.

\begin{tabular}{cccccccccc}
\hline Parâmetro & Período & $\mathbf{n}$ & média & $\mathbf{\pm}$ & desvio & mediana & mín & máx & coef var \\
\hline Consumo de & Controle & 24 & 2.603 & \pm & 875 & 2.589 & 1.098 & 4.004 & $34 \%$ \\
$\mathrm{CaO}(\mathrm{kg} / \mathrm{dia})$ & Com lodo & 15 & 5.384 & \pm & 1.453 & 5.651 & 3.299 & 8.019 & $27 \%$ \\
$\mathrm{Consumo} \mathrm{de}$ & Controle & 24 & 2.093 & \pm & 693 & 2.027 & 868 & 3.203 & $33 \%$ \\
$\mathrm{FeCl}_{3}(\mathrm{~kg} / \mathrm{dia})$ & Com lodo & 15 & 2.910 & \pm & 769 & 2.826 & 1.135 & 4.273 & $26 \%$ \\
Produção final & Controle & 24 & 50,8 & \pm & 13,3 & 54,2 & 22,4 & 71,2 & $26 \%$ \\
de lodo (t/d) & Com lodo & 13 & 76,8 & \pm & 13,0 & 77,4 & 58,5 & 96,3 & $17 \%$ \\
Teor de sólidos & Controle & 24 & 35,9 & \pm & 2,5 & 36,0 & 30,0 & 40,0 & $7 \%$ \\
lodo & Com lodo & 15 & 36,1 & \pm & 3,9 & 35,0 & 31,0 & 42,0 & $11 \%$ \\
desidratado (\%) & Com
\end{tabular}

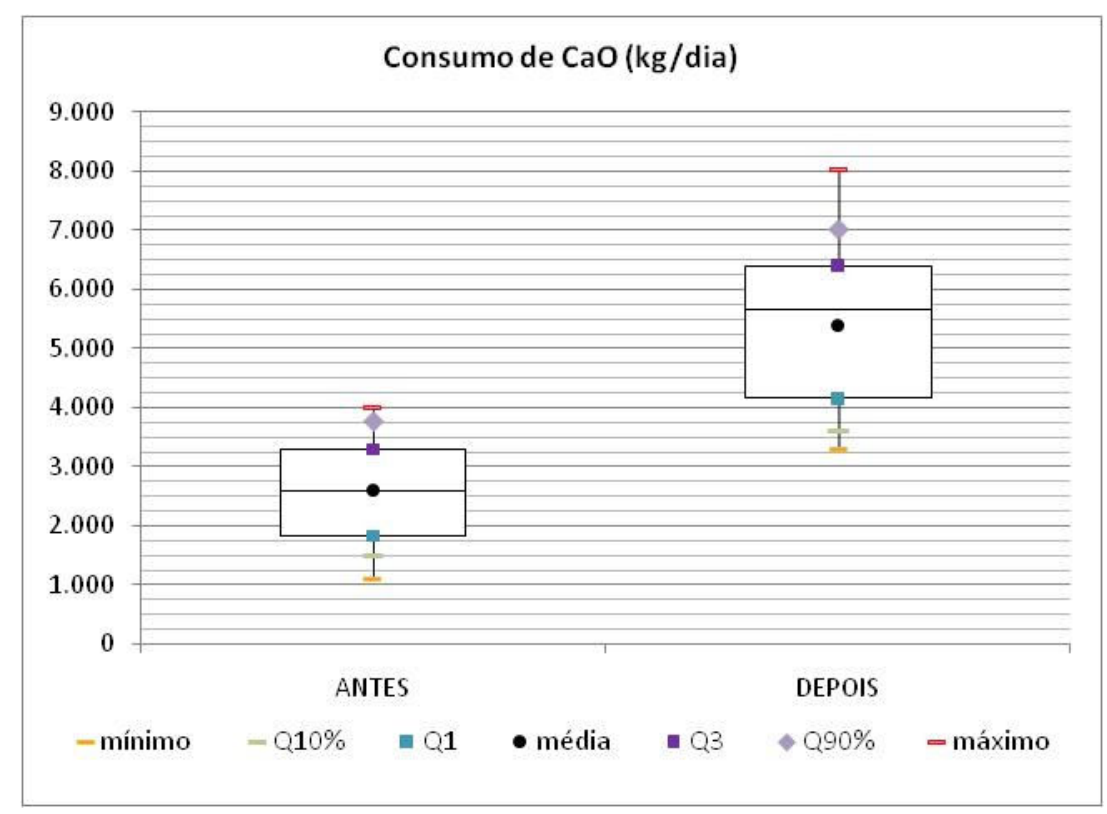

Figura 87 - Consumo de CaO no condicionamento do lodo (kg/dia). 


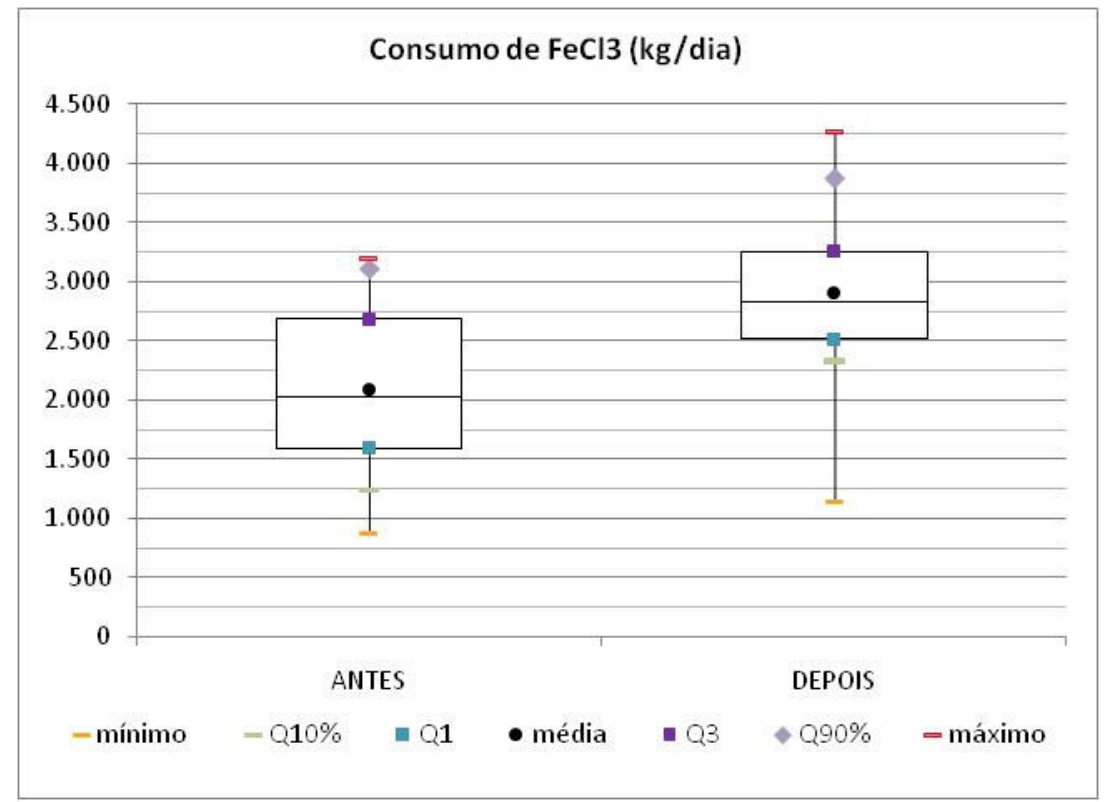

Figura 88 - Consumo de $\mathrm{FeCl}_{3}$ no condicionamento do lodo (kg/dia).

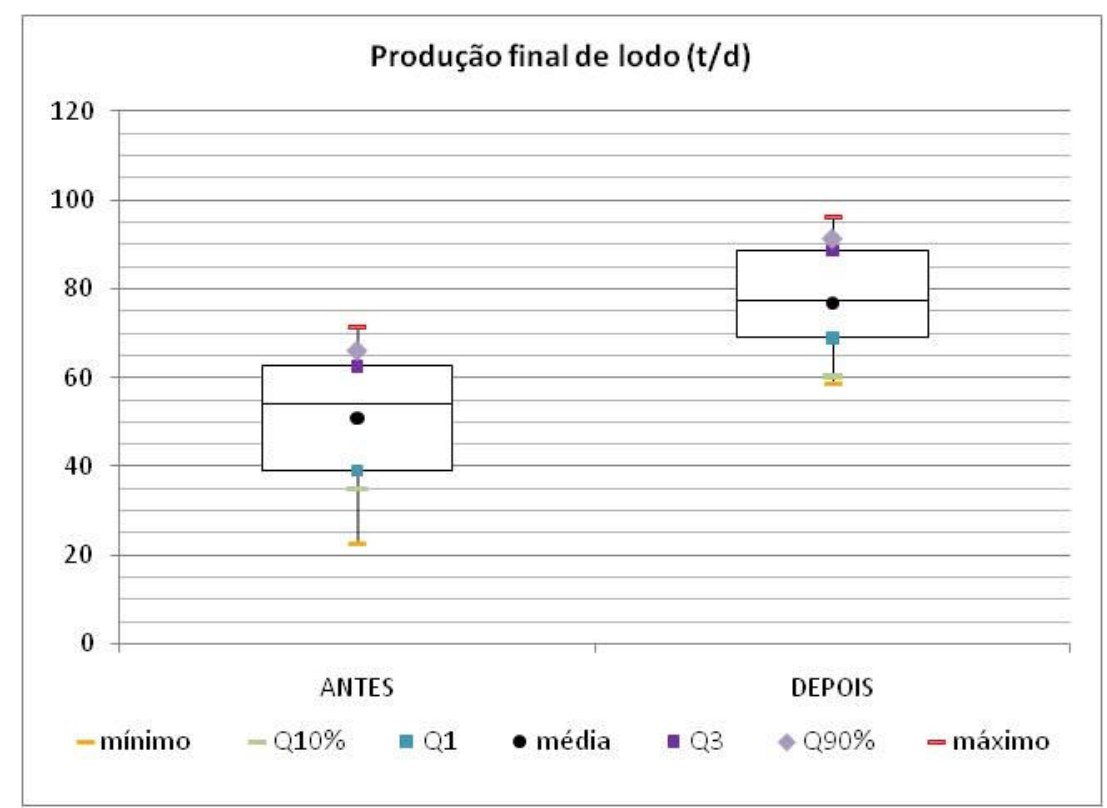

Figura 89 - Produção Final de lodo (t/d). 


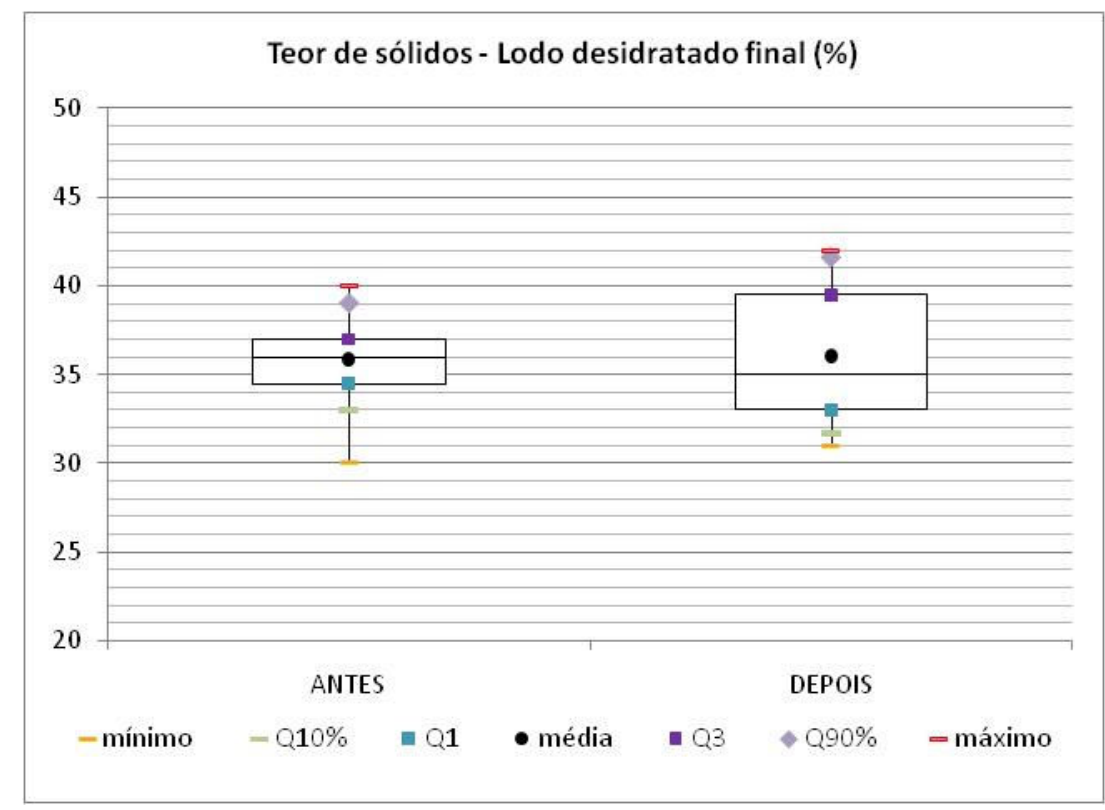

Figura 90 - Teor de Sólidos no lodo desidratado final da ETE ABC (\%).

\subsection{Validação estatística das análises}

Uma vez analisados os dados sob o ponto de vista da estatística descritiva, convém analisá-los mais criticamente, utilizando-se de ferramentas mais robustas, como regressão e testes de hipóteses, conforme explicitado no item 4.4.

A Tabela 18 abaixo apresenta o resumo dos estudos realizados ${ }^{1}$, incluindo as análises feitas em conjunto com o CEA (IME-USP), detalhadas no Anexo D.

\footnotetext{
${ }^{1}$ Notar que onde se lê "igual" na tabela deve-se entender como "não é estatisticamente diferente".
} 
Tabela 18 - Resumo das Análises Estatísticas.

\begin{tabular}{|c|c|c|c|c|}
\hline Variável & $\begin{array}{l}\text { Resultado da Análise } \\
\text { Estatística Descritiva }\end{array}$ & $\begin{array}{c}\text { Análise } \\
\text { Estatística }\end{array}$ & Resultado da Análise Estatística Inferencial & Conclusão \\
\hline Vazão (m³/s) & $\begin{array}{l}\text { Aumento gradual com o } \\
\text { passar do tempo }\end{array}$ & $\begin{array}{l}\text { Teste de Variância } \\
\text { e Teste de Médias }\end{array}$ & $\begin{array}{l}\text { Variância amostral obteve aumento } \\
\text { significativo no período com lodo comparado } \\
\text { ao período controle; médias são diferentes e } \\
\text { tal métrica teve aumento com a adição do } \\
\text { Lodo. }\end{array}$ & $\begin{array}{l}\text { Houve de fato o aumento } \\
\text { indicado pela estatística } \\
\text { descritiva }\end{array}$ \\
\hline DBO afluente (mg/L) & $\begin{array}{l}\text { Aumento no período } \\
\text { com lodo }\end{array}$ & $\begin{array}{l}\text { Teste de Variância } \\
\text { e Teste de Médias }\end{array}$ & $\begin{array}{l}\text { Variância igual em ambos os períodos; } \\
\text { médias são diferentes e tal métrica teve } \\
\text { aumento com a adição do Lodo. }\end{array}$ & $\begin{array}{l}\text { Houve de fato o aumento } \\
\text { indicado pela estatística } \\
\text { descritiva }\end{array}$ \\
\hline DBO efluente final (mg/L) & Manutenção da média & $\begin{array}{l}\text { Teste de Variância } \\
\text { e Teste de Médias }\end{array}$ & $\begin{array}{c}\text { Variáveis em que as médias e as variâncias } \\
\text { são iguais. }\end{array}$ & $\begin{array}{l}\text { Houve de fato a manutenção } \\
\text { indicado pela estatística } \\
\text { descritiva }\end{array}$ \\
\hline $\begin{array}{l}\text { Eficiência de remoção total } \\
\text { na ETE - DBO }(\%)\end{array}$ & $\begin{array}{l}\text { Aumento no período } \\
\text { com lodo }\end{array}$ & $\begin{array}{l}\text { Teste de Variância } \\
\text { e Teste de Médias }\end{array}$ & $\begin{array}{l}\text { Variância igual em ambos os períodos; } \\
\text { médias são diferentes e tal métrica teve } \\
\text { aumento com a adição do Lodo. }\end{array}$ & $\begin{array}{l}\text { Houve de fato o aumento } \\
\text { indicado pela estatística } \\
\text { descritiva }\end{array}$ \\
\hline DQO afluente (mg/L) & $\begin{array}{l}\text { Aumento no período } \\
\text { com lodo }\end{array}$ & $\begin{array}{l}\text { Teste de Variância } \\
\text { e Teste de Médias }\end{array}$ & $\begin{array}{c}\text { Variáveis em que as médias e as variâncias } \\
\text { são iguais. }\end{array}$ & $\begin{array}{l}\text { A mudança indicada pela } \\
\text { estatística descritiva não é } \\
\text { significativa }\end{array}$ \\
\hline DQO efluente final (mg/L) & Manutenção da média & $\begin{array}{l}\text { Teste de Variância } \\
\text { e Teste de Médias }\end{array}$ & $\begin{array}{c}\text { Variáveis em que as médias e as variâncias } \\
\text { são iguais. }\end{array}$ & $\begin{array}{l}\text { Houve de fato a manutenção } \\
\text { indicada pela estatística } \\
\text { descritiva }\end{array}$ \\
\hline $\begin{array}{l}\text { Eficiência de remoção total } \\
\text { na ETE - DQO }(\%)\end{array}$ & $\begin{array}{l}\text { Aumento no período } \\
\text { com lodo }\end{array}$ & $\begin{array}{l}\text { Teste de Variância } \\
\text { e Teste de Médias }\end{array}$ & $\begin{array}{l}\text { Variância igual em ambos os períodos; } \\
\text { médias são diferentes e tal métrica teve } \\
\text { aumento com a adição do Lodo. }\end{array}$ & $\begin{array}{l}\text { Houve de fato o aumento } \\
\text { indicado pela estatística } \\
\text { descritiva }\end{array}$ \\
\hline SST afluente (mg/L) & $\begin{array}{l}\text { Aumento no período } \\
\text { com lodo }\end{array}$ & $\begin{array}{l}\text { Teste de Variância } \\
\text { e Teste de Médias }\end{array}$ & $\begin{array}{l}\text { Variância igual em ambos os períodos; } \\
\text { médias são diferentes e tal métrica teve } \\
\text { aumento com a adição do Lodo. }\end{array}$ & $\begin{array}{l}\text { Houve de fato o aumento } \\
\text { indicado pela estatística } \\
\text { descritiva }\end{array}$ \\
\hline SST efluente final (mg/L) & $\begin{array}{l}\text { Diminuição no período } \\
\text { com lodo }\end{array}$ & $\begin{array}{c}\text { Regressão } \\
\text { Robusta }\end{array}$ & $\begin{array}{c}\text { Inclinação muda de decrescente para } \\
\text { crescente, sendo mais acentuada no período } \\
\text { com lodo; nível médio menor no período com } \\
\text { lodo. }\end{array}$ & $\begin{array}{c}\text { Houve de fato a diminuição } \\
\text { indicada pela estatística } \\
\text { descritiva }\end{array}$ \\
\hline
\end{tabular}


Tabela 18 - Resumo das Análises Estatísticas (continuação).

\begin{tabular}{|c|c|c|c|c|}
\hline Variável & $\begin{array}{l}\text { Resultado da Análise } \\
\text { Estatística Descritiva }\end{array}$ & $\begin{array}{c}\text { Análise } \\
\text { Estatística }\end{array}$ & Resultado da Análise Estatística Inferencial & Conclusão \\
\hline $\begin{array}{c}\text { Eficiência de remoção total } \\
\text { na ETE - SST (\%) }\end{array}$ & $\begin{array}{l}\text { Aumento no período } \\
\text { com lodo }\end{array}$ & $\begin{array}{l}\text { Teste de Variância } \\
\text { e Teste de Médias }\end{array}$ & $\begin{array}{l}\text { Variância amostral obteve aumento } \\
\text { significativo no período com lodo comparado } \\
\text { ao período controle; médias são diferentes e } \\
\text { tal métrica teve aumento com a adição do } \\
\text { Lodo. }\end{array}$ & $\begin{array}{l}\text { Houve de fato o aumento } \\
\text { indicado pela estatística } \\
\text { descritiva }\end{array}$ \\
\hline SSV afluente (mg/L) & $\begin{array}{l}\text { Aumento no período } \\
\text { com lodo }\end{array}$ & $\begin{array}{l}\text { Teste de Variância } \\
\text { e Teste de Médias }\end{array}$ & $\begin{array}{l}\text { Variância igual em ambos os períodos; } \\
\text { médias são diferentes e tal métrica teve } \\
\text { aumento com a adição do Lodo. }\end{array}$ & $\begin{array}{l}\text { Houve de fato o aumento } \\
\text { indicado pela estatística } \\
\text { descritiva }\end{array}$ \\
\hline SSV efluente final (mg/L) & $\begin{array}{l}\text { Diminuição no período } \\
\text { com lodo }\end{array}$ & $\begin{array}{l}\text { Regressão } \\
\text { Robusta }\end{array}$ & $\begin{array}{c}\text { Inclinação muda de decrescente para } \\
\text { crescente, sendo mais acentuada no período } \\
\text { com lodo; nível médio menor no período com } \\
\text { lodo. }\end{array}$ & $\begin{array}{l}\text { Houve de fato a diminuição } \\
\text { indicada pela estatística } \\
\text { descritiva }\end{array}$ \\
\hline $\begin{array}{c}\text { Eficiência de remoção total } \\
\text { na ETE - SSV (\%) }\end{array}$ & $\begin{array}{l}\text { Aumento no período } \\
\text { com lodo }\end{array}$ & $\begin{array}{l}\text { Teste de Variância } \\
\text { e Teste de Médias }\end{array}$ & $\begin{array}{l}\text { Variância amostral obteve aumento } \\
\text { significativo no período com lodo comparado } \\
\text { ao período controle; médias são diferentes e } \\
\text { tal métrica teve aumento com a adição do } \\
\text { Lodo. }\end{array}$ & $\begin{array}{l}\text { Houve de fato o aumento } \\
\text { indicado pela estatística } \\
\text { descritiva }\end{array}$ \\
\hline SSVISST afluente & $\begin{array}{l}\text { Diminuição no período } \\
\text { com lodo }\end{array}$ & $\begin{array}{l}\text { Teste de Variância } \\
\text { e Teste de Médias }\end{array}$ & $\begin{array}{l}\text { Variância igual em ambos os períodos; } \\
\text { médias são diferentes e tal métrica teve } \\
\text { diminuição com a adição do Lodo. }\end{array}$ & $\begin{array}{c}\text { Houve de fato a diminuição } \\
\text { indicada pela estatística } \\
\text { descritiva }\end{array}$ \\
\hline NTK afluente (mg/L) & Manutenção da média & $\begin{array}{l}\text { Teste de Variância } \\
\text { e Teste de Médias }\end{array}$ & $\begin{array}{c}\text { Variáveis em que as médias e as variâncias } \\
\text { são iguais. }\end{array}$ & $\begin{array}{c}\text { Houve de fato a manutenção } \\
\text { indicada pela estatística } \\
\text { descritiva }\end{array}$ \\
\hline NTK efluente final (mg/L) & Manutenção da média & $\begin{array}{l}\text { Teste de Variância } \\
\text { e Teste de Médias }\end{array}$ & $\begin{array}{c}\text { Variáveis em que as médias e as variâncias } \\
\text { são iguais. }\end{array}$ & $\begin{array}{l}\text { Houve de fato a manutenção } \\
\text { indicada pela estatística } \\
\text { descritiva }\end{array}$ \\
\hline $\begin{array}{c}\text { Eficiência de remoção total } \\
\text { na ETE - NTK }(\%)\end{array}$ & $\begin{array}{l}\text { Diminuição no período } \\
\text { com lodo }\end{array}$ & $\begin{array}{l}\text { Teste de Variância } \\
\text { e Teste de Médias }\end{array}$ & $\begin{array}{c}\text { Variáveis em que as médias e as variâncias } \\
\text { são iguais. }\end{array}$ & $\begin{array}{c}\text { A mudança indicada pela } \\
\text { estatística descritiva não é } \\
\text { significativa }\end{array}$ \\
\hline $\mathrm{N}-\mathrm{NH}_{3}$ afluente $(\mathrm{mg} / \mathrm{L})$ & Manutenção da média & $\begin{array}{l}\text { Teste de Variância } \\
\text { e Teste de Médias }\end{array}$ & $\begin{array}{c}\text { Variáveis em que as médias e as variâncias } \\
\text { são iguais. }\end{array}$ & $\begin{array}{c}\text { Houve de fato a manutenção } \\
\text { indicada pela estatística } \\
\text { descritiva }\end{array}$ \\
\hline
\end{tabular}


Tabela 18 - Resumo das Análises Estatísticas (continuação)

\begin{tabular}{|c|c|c|c|c|}
\hline Variável & $\begin{array}{l}\text { Resultado da Análise } \\
\text { Estatística Descritiva }\end{array}$ & $\begin{array}{l}\text { Análise } \\
\text { Estatística }\end{array}$ & Resultado da Análise Estatística Inferencial & Conclusão \\
\hline $\mathrm{N}-\mathrm{NH}_{3}$ efluente final (mg/L) & $\begin{array}{l}\text { Aumento no período } \\
\text { com lodo }\end{array}$ & $\begin{array}{l}\text { Teste de Variância } \\
\text { e Teste de Médias }\end{array}$ & $\begin{array}{c}\text { Variáveis em que as médias e as variâncias } \\
\text { são iguais. }\end{array}$ & $\begin{array}{l}\text { A mudança indicada pela } \\
\text { estatística descritiva não é } \\
\text { significativa }\end{array}$ \\
\hline $\begin{array}{c}\text { Eficiência de remoção total } \\
\text { na ETE - N-NH}(\%)\end{array}$ & $\begin{array}{l}\text { Diminuição no período } \\
\text { com lodo }\end{array}$ & $\begin{array}{l}\text { Teste de Variância } \\
\text { e Teste de Médias }\end{array}$ & $\begin{array}{c}\text { Variáveis em que as médias e as variâncias } \\
\text { são iguais. }\end{array}$ & $\begin{array}{l}\text { A mudança indicada pela } \\
\text { estatística descritiva não é } \\
\text { significativa }\end{array}$ \\
\hline $\mathrm{P}$ afluente (mg/L) & $\begin{array}{l}\text { Aumento no período } \\
\text { com lodo }\end{array}$ & $\begin{array}{l}\text { Teste de Variância } \\
\text { e Teste de Médias }\end{array}$ & $\begin{array}{l}\text { Variância amostral obteve aumento } \\
\text { significativo no período com lodo comparado } \\
\text { ao período controle; médias são diferentes e } \\
\text { tal métrica teve aumento com a adição do } \\
\text { Lodo. }\end{array}$ & $\begin{array}{l}\text { Houve de fato o aumento } \\
\text { indicado pela estatística } \\
\text { descritiva }\end{array}$ \\
\hline$P$ efluente final (mg/L) & $\begin{array}{l}\text { Diminuição no período } \\
\text { com lodo }\end{array}$ & $\begin{array}{l}\text { Teste de Variância } \\
\text { e Teste de Médias }\end{array}$ & $\begin{array}{l}\text { Variância igual em ambos os períodos; } \\
\text { médias são diferentes e tal métrica teve } \\
\text { diminuição com a adição do Lodo. }\end{array}$ & $\begin{array}{c}\text { Houve de fato a diminuição } \\
\text { indicada pela estatística } \\
\text { descritiva }\end{array}$ \\
\hline $\begin{array}{l}\text { Eficiência de remoção total } \\
\text { na ETE - P (\%) }\end{array}$ & $\begin{array}{l}\text { Aumento no período } \\
\text { com lodo }\end{array}$ & $\begin{array}{l}\text { Teste de Variância } \\
\text { e Teste de Médias }\end{array}$ & $\begin{array}{l}\text { Variância igual em ambos os períodos; } \\
\text { médias são diferentes e tal métrica teve } \\
\text { aumento com a adição do Lodo. }\end{array}$ & $\begin{array}{l}\text { Houve de fato o aumento } \\
\text { indicado pela estatística } \\
\text { descritiva }\end{array}$ \\
\hline Fe afluente (mg/L) & $\begin{array}{l}\text { Aumento significativo no } \\
\text { período com lodo }\end{array}$ & $\begin{array}{l}\text { Regressão } \\
\text { Robusta }\end{array}$ & $\begin{array}{l}\text { Grande mudança nos valores médios da série } \\
\text { em ambos os períodos e as inclinações em } \\
\text { ambos os períodos são decrescentes, porém, } \\
\text { a grandeza do parâmetro de inclinação na } \\
\text { equação do modelo ajustado é bem distinta; } \\
\text { nível médio maior no período com lodo. }\end{array}$ & $\begin{array}{l}\text { Houve de fato o aumento } \\
\text { indicado pela estatística } \\
\text { descritiva }\end{array}$ \\
\hline Fe efluente final (mg/L) & $\begin{array}{l}\text { Aumento no período } \\
\text { com lodo }\end{array}$ & $\begin{array}{l}\text { Regressão } \\
\text { Robusta }\end{array}$ & $\begin{array}{l}\text { A inclinação crescente bem acentuada para o } \\
\text { período “Lodo", contrário a inclinação no } \\
\text { período “Controle” que é sutilmente } \\
\text { decrescente; nível médio maior no período } \\
\text { com lodo. }\end{array}$ & $\begin{array}{l}\text { Houve de fato o aumento } \\
\text { indicado pela estatística } \\
\text { descritiva }\end{array}$ \\
\hline $\begin{array}{c}\text { Eficiência de remoção total } \\
\text { na ETE - Fe (\%) }\end{array}$ & $\begin{array}{l}\text { Aumento no período } \\
\text { com lodo }\end{array}$ & $\begin{array}{l}\text { Teste de Variância } \\
\text { e Teste de Médias }\end{array}$ & $\begin{array}{c}\text { Variáveis em que as médias e as variâncias } \\
\text { são iguais. }\end{array}$ & $\begin{array}{l}\text { A mudança indicada pela } \\
\text { estatística descritiva não é } \\
\text { significativa }\end{array}$ \\
\hline
\end{tabular}


Tabela 18 - Resumo das Análises Estatísticas (continuação).

\begin{tabular}{|c|c|c|c|c|}
\hline Variável & $\begin{array}{l}\text { Resultado da Análise } \\
\text { Estatística Descritiva }\end{array}$ & $\begin{array}{c}\text { Análise } \\
\text { Estatística }\end{array}$ & Resultado da Análise Estatística Inferencial & Conclusão \\
\hline TAS - decantador primário & Manutenção da média & $\begin{array}{l}\text { Teste de Variância } \\
\text { e Teste de Médias }\end{array}$ & $\begin{array}{c}\text { Variáveis em que as médias e as variâncias } \\
\text { são iguais. }\end{array}$ & $\begin{array}{c}\text { Houve de fato a manutenção } \\
\text { indicada pela estatística } \\
\text { descritiva }\end{array}$ \\
\hline $\begin{array}{l}\text { DBO efluente primário } \\
(\mathrm{mg} / \mathrm{L})\end{array}$ & $\begin{array}{l}\text { Aumento no período } \\
\text { com lodo }\end{array}$ & $\begin{array}{l}\text { Teste de Variância } \\
\text { e Teste de Médias }\end{array}$ & $\begin{array}{l}\text { Variância amostral obteve aumento } \\
\text { significativo no período com lodo comparado } \\
\text { ao período controle; médias são iguais } \\
\text { comparando os dois períodos. }\end{array}$ & $\begin{array}{c}\text { A mudança indicada pela } \\
\text { estatística descritiva não é } \\
\text { significativa }\end{array}$ \\
\hline $\begin{array}{l}\text { Eficiência de remoção DBO } \\
\text { - decantador primário (\%) }\end{array}$ & Manutenção da média & $\begin{array}{l}\text { Teste de Variância } \\
\text { e Teste de Médias }\end{array}$ & $\begin{array}{c}\text { Variáveis em que as médias e as variâncias } \\
\text { são iguais. }\end{array}$ & $\begin{array}{l}\text { Houve de fato a manutenção } \\
\text { indicada pela estatística } \\
\text { descritiva }\end{array}$ \\
\hline $\begin{array}{l}\text { DQO efluente primário } \\
(\mathrm{mg} / \mathrm{L})\end{array}$ & Manutenção da média & $\begin{array}{l}\text { Teste de Variância } \\
\text { e Teste de Médias }\end{array}$ & $\begin{array}{l}\text { Variância amostral obteve aumento } \\
\text { significativo no período com lodo comparado } \\
\text { ao período controle; médias são iguais } \\
\text { comparando os dois períodos. }\end{array}$ & $\begin{array}{c}\text { Houve de fato a manutenção } \\
\text { indicada pela estatística } \\
\text { descritiva }\end{array}$ \\
\hline $\begin{array}{l}\text { Eficiência de remoção DQO } \\
\text { - decantador primário (\%) }\end{array}$ & Manutenção da média & $\begin{array}{l}\text { Teste de Variância } \\
\text { e Teste de Médias }\end{array}$ & $\begin{array}{c}\text { Variáveis em que as médias e as variâncias } \\
\text { são iguais. }\end{array}$ & $\begin{array}{c}\text { Houve de fato a manutenção } \\
\text { indicada pela estatística } \\
\text { descritiva }\end{array}$ \\
\hline $\begin{array}{l}\text { SST efluente primário } \\
(\mathrm{mg} / \mathrm{L})\end{array}$ & $\begin{array}{l}\text { Aumento no período } \\
\text { com lodo }\end{array}$ & $\begin{array}{l}\text { Regressão } \\
\text { Robusta }\end{array}$ & $\begin{array}{c}\text { Inclinação muda de decrescente para } \\
\text { crescente; nível médio maior no período com } \\
\text { lodo. }\end{array}$ & $\begin{array}{l}\text { Houve de fato o aumento } \\
\text { indicado pela estatística } \\
\text { descritiva }\end{array}$ \\
\hline $\begin{array}{l}\text { Eficiência de remoção SST - } \\
\text { decantador primário (\%) }\end{array}$ & $\begin{array}{l}\text { Aumento no período } \\
\text { com lodo }\end{array}$ & $\begin{array}{l}\text { Regressão } \\
\text { Robusta }\end{array}$ & $\begin{array}{c}\text { Variáveis em que as médias e as variâncias } \\
\text { são iguais. }\end{array}$ & $\begin{array}{l}\text { A mudança indicada pela } \\
\text { estatística descritiva não é } \\
\text { significativa }\end{array}$ \\
\hline $\begin{array}{l}\text { SSV efluente primário } \\
\text { (mg/L) }\end{array}$ & $\begin{array}{l}\text { Aumento no período } \\
\text { com lodo }\end{array}$ & $\begin{array}{l}\text { Regressão } \\
\text { Robusta }\end{array}$ & $\begin{array}{l}\text { Inclinação muda de decrescente para } \\
\text { crescente; nível médio maior no período com } \\
\text { lodo. }\end{array}$ & $\begin{array}{l}\text { Houve de fato o aumento } \\
\text { indicado pela estatística } \\
\text { descritiva }\end{array}$ \\
\hline $\begin{array}{l}\text { Eficiência de remoção SSV - } \\
\text { decantador primário (\%) }\end{array}$ & $\begin{array}{l}\text { Aumento no período } \\
\text { com lodo }\end{array}$ & $\begin{array}{l}\text { Teste de Variância } \\
\text { e Teste de Médias }\end{array}$ & $\begin{array}{c}\text { Variáveis em que as médias e as variâncias } \\
\text { são iguais. }\end{array}$ & $\begin{array}{l}\text { A mudança indicada pela } \\
\text { estatística descritiva não é } \\
\text { significativa }\end{array}$ \\
\hline
\end{tabular}


Tabela 18 - Resumo das Análises Estatísticas (continuação).

\begin{tabular}{|c|c|c|c|c|}
\hline Variável & $\begin{array}{l}\text { Resultado da Análise } \\
\text { Estatística Descritiva }\end{array}$ & $\begin{array}{c}\text { Análise } \\
\text { Estatística }\end{array}$ & Resultado da Análise Estatística Inferencial & Conclusão \\
\hline $\begin{array}{l}\text { NTK efluente primário } \\
\text { (mg/L) }\end{array}$ & Manutenção da média & $\begin{array}{l}\text { Teste de Variância } \\
\text { e Teste de Médias }\end{array}$ & $\begin{array}{c}\text { Variáveis em que as médias e as variâncias } \\
\text { são iguais. }\end{array}$ & $\begin{array}{c}\text { Houve de fato a manutenção } \\
\text { indicada pela estatística } \\
\text { descritiva }\end{array}$ \\
\hline $\begin{array}{l}\text { Eficiência de remoção NTK - } \\
\text { decantador primário (\%) }\end{array}$ & $\begin{array}{l}\text { Aumento no período } \\
\text { com lodo }\end{array}$ & $\begin{array}{l}\text { Teste de Variância } \\
\text { e Teste de Médias }\end{array}$ & $\begin{array}{l}\text { Variância igual em ambos os períodos; } \\
\text { médias são diferentes e tal métrica teve } \\
\text { aumento com a adição do Lodo. }\end{array}$ & $\begin{array}{c}\text { Houve de fato o aumento } \\
\text { indicado pela estatística } \\
\text { descritiva }\end{array}$ \\
\hline $\mathrm{P}$ efluente primário $(\mathrm{mg} / \mathrm{L})$ & Manutenção da média & $\begin{array}{l}\text { Teste de Variância } \\
\text { e Teste de Médias }\end{array}$ & $\begin{array}{l}\text { Variância amostral obteve aumento } \\
\text { significativo no período com lodo comparado } \\
\text { ao período controle; médias são iguais } \\
\text { comparando os dois períodos. }\end{array}$ & $\begin{array}{c}\text { Houve de fato a manutenção } \\
\text { indicada pela estatística } \\
\text { descritiva }\end{array}$ \\
\hline $\begin{array}{l}\text { Eficiência de remoção } P \text { - } \\
\text { decantador primário (\%) }\end{array}$ & $\begin{array}{l}\text { Aumento significativo no } \\
\text { período com lodo }\end{array}$ & $\begin{array}{l}\text { Teste de Variância } \\
\text { e Teste de Médias }\end{array}$ & $\begin{array}{l}\text { Variância amostral obteve aumento } \\
\text { significativo no período com lodo comparado } \\
\text { ao período controle; médias são diferentes e } \\
\text { tal métrica teve aumento com a adição do } \\
\text { Lodo. }\end{array}$ & $\begin{array}{l}\text { Houve de fato o aumento } \\
\text { indicado pela estatística } \\
\text { descritiva }\end{array}$ \\
\hline Fe efluente primário (mg/L) & $\begin{array}{l}\text { Aumento significativo no } \\
\text { período com lodo }\end{array}$ & $\begin{array}{l}\text { Teste de Variância } \\
\text { e Teste de Médias }\end{array}$ & $\begin{array}{l}\text { Variância amostral obteve aumento } \\
\text { significativo no período com lodo comparado } \\
\text { ao período controle; médias são iguais } \\
\text { comparando os dois períodos. }\end{array}$ & $\begin{array}{l}\text { A mudança indicada pela } \\
\text { estatística descritiva não é } \\
\text { significativa }\end{array}$ \\
\hline $\begin{array}{c}\text { Eficiência de remoção Fe - } \\
\text { decantador primário (\%) }\end{array}$ & $\begin{array}{l}\text { Aumento significativo no } \\
\text { período com lodo }\end{array}$ & $\begin{array}{l}\text { Teste de Variância } \\
\text { e Teste de Médias }\end{array}$ & $\begin{array}{l}\text { Variância igual em ambos os períodos; } \\
\text { médias são diferentes e tal métrica teve } \\
\text { aumento com a adição do Lodo. }\end{array}$ & $\begin{array}{l}\text { Houve de fato o aumento } \\
\text { indicado pela estatística } \\
\text { descritiva }\end{array}$ \\
\hline $\begin{array}{l}\text { Vazão de Lodo Primário } \\
\text { (L/s) }\end{array}$ & $\begin{array}{l}\text { Aumento no período } \\
\text { com lodo }\end{array}$ & $\begin{array}{l}\text { Teste de Variância } \\
\text { e Teste de Médias }\end{array}$ & $\begin{array}{l}\text { Variância igual em ambos os períodos; } \\
\text { médias são diferentes e tal métrica teve } \\
\text { aumento com a adição do Lodo. }\end{array}$ & $\begin{array}{l}\text { Houve de fato o aumento } \\
\text { indicado pela estatística } \\
\text { descritiva }\end{array}$ \\
\hline SST - Lodo Primário (mg/L) & $\begin{array}{l}\text { Diminuição no período } \\
\text { com lodo }\end{array}$ & $\begin{array}{l}\text { Regressão } \\
\text { Robusta }\end{array}$ & $\begin{array}{l}\text { Níveis médios diferentes, com tendência de } \\
\text { diminuição no período “Lodo". }\end{array}$ & $\begin{array}{l}\text { Houve de fato a diminuição } \\
\text { indicada pela estatística } \\
\text { descritiva }\end{array}$ \\
\hline
\end{tabular}


Tabela 18 - Resumo das Análises Estatísticas (continuação).

\begin{tabular}{|c|c|c|c|c|}
\hline Variável & $\begin{array}{l}\text { Resultado da Análise } \\
\text { Estatística Descritiva }\end{array}$ & $\begin{array}{l}\text { Análise } \\
\text { Estatística }\end{array}$ & Resultado da Análise Estatística Inferencial & Conclusão \\
\hline SSV - Lodo Primário (mg/L) & Manutenção da média & $\begin{array}{l}\text { Teste de Variância } \\
\text { e Teste de Médias }\end{array}$ & $\begin{array}{l}\text { Variância igual em ambos os períodos; } \\
\text { médias são diferentes e tal métrica teve } \\
\text { diminuição com a adição do Lodo. }\end{array}$ & $\begin{array}{l}\text { A manutenção indicada pela } \\
\text { estatística descritiva não é real, } \\
\text { ocorrendo uma diminuição da } \\
\text { média no período com lodo }\end{array}$ \\
\hline $\begin{array}{l}\text { TAS - adensador por } \\
\text { gravidade }\end{array}$ & $\begin{array}{l}\text { Aumento no período } \\
\text { com lodo }\end{array}$ & $\begin{array}{l}\text { Teste de Variância } \\
\text { e Teste de Médias }\end{array}$ & $\begin{array}{l}\text { Variância amostral obteve aumento } \\
\text { significativo no período com lodo comparado } \\
\text { ao período controle; médias são diferentes e } \\
\text { tal métrica teve aumento com a adição do } \\
\text { Lodo. } \\
\text { Variância amostral obteve aumento }\end{array}$ & $\begin{array}{l}\text { Houve de fato o aumento } \\
\text { indicado pela estatística } \\
\text { descritiva }\end{array}$ \\
\hline $\begin{array}{l}\text { TASol - adensador por } \\
\text { gravidade }\end{array}$ & $\begin{array}{l}\text { Aumento significativo no } \\
\text { período com lodo }\end{array}$ & $\begin{array}{l}\text { Teste de Variância } \\
\text { e Teste de Médias }\end{array}$ & $\begin{array}{l}\text { significativo no período com lodo comparado } \\
\text { ao período controle; médias são diferentes e } \\
\text { tal métrica teve aumento com a adição do } \\
\text { Lodo. }\end{array}$ & $\begin{array}{l}\text { Houve de fato o aumento } \\
\text { indicado pela estatística } \\
\text { descritiva }\end{array}$ \\
\hline $\begin{array}{l}\text { Vazão de Lodo Adensado } \\
\text { (L/s) }\end{array}$ & $\begin{array}{l}\text { Aumento no período } \\
\text { com lodo }\end{array}$ & $\begin{array}{l}\text { Teste de Variância } \\
\text { e Teste de Médias }\end{array}$ & $\begin{array}{l}\text { Variância igual em ambos os períodos; } \\
\text { médias são diferentes e tal métrica teve } \\
\text { aumento com a adição do Lodo. }\end{array}$ & $\begin{array}{l}\text { Houve de fato o aumento } \\
\text { indicado pela estatística } \\
\text { descritiva }\end{array}$ \\
\hline $\begin{array}{l}\text { SST - Lodo Adensado } \\
\text { (mg/L) }\end{array}$ & Manutenção da média & $\begin{array}{l}\text { Regressão } \\
\text { Robusta }\end{array}$ & $\begin{array}{l}\text { Níveis médios diferentes, com tendência de } \\
\text { diminuição no período "Lodo". }\end{array}$ & $\begin{array}{l}\text { A manutenção indicada pela } \\
\text { estatística descritiva não é real, } \\
\text { ocorrendo uma diminuição da } \\
\text { média no período com lodo }\end{array}$ \\
\hline $\begin{array}{l}\text { SSV - Lodo Adensado } \\
\text { (mg/L) }\end{array}$ & Manutenção da média & $\begin{array}{l}\text { Teste de Variância } \\
\text { e Teste de Médias }\end{array}$ & $\begin{array}{c}\text { Variáveis em que as médias e as variâncias } \\
\text { são iguais. }\end{array}$ & $\begin{array}{l}\text { Houve de fato a manutenção } \\
\text { indicada pela estatística } \\
\text { descritiva }\end{array}$ \\
\hline $\begin{array}{l}\text { SST tanque de aeração } \\
(\mathrm{mg} / \mathrm{L})\end{array}$ & $\begin{array}{l}\text { Aumento no período } \\
\text { com lodo }\end{array}$ & $\begin{array}{l}\text { Regressão } \\
\text { Robusta }\end{array}$ & $\begin{array}{l}\text { Inclinação crescente em ambos os períodos, } \\
\text { porém, em “Lodo" tal crescimento é bem mais } \\
\text { acentuado. }\end{array}$ & $\begin{array}{l}\text { Houve de fato o aumento } \\
\text { indicado pela estatística } \\
\text { descritiva }\end{array}$ \\
\hline $\begin{array}{l}\text { SSV tanque de aeração } \\
(\mathrm{mg} / \mathrm{L})\end{array}$ & $\begin{array}{l}\text { Aumento no período } \\
\text { com lodo }\end{array}$ & $\begin{array}{l}\text { Regressão } \\
\text { Robusta }\end{array}$ & $\begin{array}{l}\text { Inclinação crescente em ambos os períodos, } \\
\text { porém, em "Lodo" tal crescimento é bem mais } \\
\text { acentuado. }\end{array}$ & $\begin{array}{l}\text { Houve de fato o aumento } \\
\text { indicado pela estatística } \\
\text { descritiva }\end{array}$ \\
\hline
\end{tabular}


Tabela 18 - Resumo das Análises Estatísticas (continuação)

\begin{tabular}{|c|c|c|c|c|}
\hline Variável & $\begin{array}{l}\text { Resultado da Análise } \\
\text { Estatística Descritiva }\end{array}$ & $\begin{array}{c}\text { Análise } \\
\text { Estatística }\end{array}$ & Resultado da Análise Estatística Inferencial & Conclusão \\
\hline $\mathrm{IVL}(\mathrm{mL} / \mathrm{g})$ & $\begin{array}{l}\text { Aumento no período } \\
\text { com lodo }\end{array}$ & $\begin{array}{l}\text { Regressão } \\
\text { Robusta }\end{array}$ & $\begin{array}{l}\text { Inclinação crescente em ambos os períodos, } \\
\text { porém a grandeza do parâmetro de inclinação } \\
\text { na equação do modelo é maior no período } \\
\text { "Lodo". }\end{array}$ & $\begin{array}{l}\text { Houve de fato o aumento } \\
\text { indicado pela estatística } \\
\text { descritiva }\end{array}$ \\
\hline Idade do Lodo & Manutenção da média & $\begin{array}{l}\text { Teste de Variância } \\
\text { e Teste de Médias }\end{array}$ & $\begin{array}{c}\text { Variáveis em que as médias e as variâncias } \\
\text { são iguais. }\end{array}$ & $\begin{array}{l}\text { Houve de fato a manutenção } \\
\text { indicada pela estatística } \\
\text { descritiva }\end{array}$ \\
\hline Relação A/M & $\begin{array}{l}\text { Aumento no período } \\
\text { com lodo }\end{array}$ & $\begin{array}{l}\text { Teste de Variância } \\
\text { e Teste de Médias }\end{array}$ & $\begin{array}{l}\text { Variância amostral obteve aumento } \\
\text { significativo no período com lodo comparado } \\
\text { ao período controle; médias são diferentes e } \\
\text { tal métrica teve aumento com a adição do } \\
\text { Lodo. }\end{array}$ & $\begin{array}{l}\text { Houve de fato o aumento } \\
\text { indicado pela estatística } \\
\text { descritiva }\end{array}$ \\
\hline $\begin{array}{l}\text { TAS - decantador } \\
\text { secundário }\end{array}$ & Manutenção da média & $\begin{array}{l}\text { Teste de Variância } \\
\text { e Teste de Médias }\end{array}$ & $\begin{array}{l}\text { Variância amostral obteve aumento } \\
\text { significativo no período com lodo comparado } \\
\text { ao período controle; médias são diferentes e } \\
\text { tal métrica teve aumento com a adição do } \\
\text { Lodo. }\end{array}$ & $\begin{array}{l}\text { A manutenção indicada pela } \\
\text { estatística descritiva não é real, } \\
\text { ocorrendo um aumento da } \\
\text { média no período com lodo }\end{array}$ \\
\hline $\begin{array}{l}\text { TASol - decantador } \\
\text { secundário }\end{array}$ & $\begin{array}{l}\text { Aumento no período } \\
\text { com lodo }\end{array}$ & $\begin{array}{l}\text { Teste de Variância } \\
\text { e Teste de Médias }\end{array}$ & $\begin{array}{l}\text { Variância igual em ambos os períodos; } \\
\text { médias são diferentes e tal métrica teve } \\
\text { aumento com a adição do Lodo. }\end{array}$ & $\begin{array}{l}\text { Houve de fato o aumento } \\
\text { indicado pela estatística } \\
\text { descritiva }\end{array}$ \\
\hline $\begin{array}{l}\text { Vazão de Lodo Recirculado } \\
\qquad(\mathrm{L} / \mathrm{s})\end{array}$ & $\begin{array}{l}\text { Aumento no período } \\
\text { com lodo }\end{array}$ & $\begin{array}{l}\text { Teste de Variância } \\
\text { e Teste de Médias }\end{array}$ & $\begin{array}{l}\text { Variância igual em ambos os períodos; } \\
\text { médias são diferentes e tal métrica teve } \\
\text { aumento com a adição do Lodo. }\end{array}$ & $\begin{array}{l}\text { Houve de fato o aumento } \\
\text { indicado pela estatística } \\
\text { descritiva }\end{array}$ \\
\hline $\begin{array}{l}\text { Vazão de Lodo Descartado } \\
\text { (L/s) }\end{array}$ & $\begin{array}{l}\text { Aumento no período } \\
\text { com lodo }\end{array}$ & $\begin{array}{l}\text { Teste de Variância } \\
\text { e Teste de Médias }\end{array}$ & $\begin{array}{l}\text { Variância igual em ambos os períodos; } \\
\text { médias são diferentes e tal métrica teve } \\
\text { aumento com a adição do Lodo. }\end{array}$ & $\begin{array}{l}\text { Houve de fato o aumento } \\
\text { indicado pela estatística } \\
\text { descritiva }\end{array}$ \\
\hline $\begin{array}{l}\text { SST - Lodo Secundário } \\
\text { (mg/L) }\end{array}$ & Manutenção da média & $\begin{array}{l}\text { Teste de Variância } \\
\text { e Teste de Médias }\end{array}$ & $\begin{array}{c}\text { Variáveis em que as médias e as variâncias } \\
\text { são iguais. }\end{array}$ & $\begin{array}{l}\text { Houve de fato a manutenção } \\
\text { indicada pela estatística } \\
\text { descritiva }\end{array}$ \\
\hline $\begin{array}{l}\text { SSV - Lodo Secundário } \\
\text { (mg/L) }\end{array}$ & Manutenção da média & $\begin{array}{l}\text { Teste de Variância } \\
\text { e Teste de Médias }\end{array}$ & $\begin{array}{c}\text { Variáveis em que as médias e as variâncias } \\
\text { são iguais. }\end{array}$ & $\begin{array}{l}\text { Houve de fato a manutenção } \\
\text { indicada pela estatística } \\
\text { descritiva }\end{array}$ \\
\hline
\end{tabular}


Tabela 18 - Resumo das Análises Estatísticas (continuação).

\begin{tabular}{|c|c|c|c|c|}
\hline Variável & $\begin{array}{l}\text { Resultado da Análise } \\
\text { Estatística Descritiva }\end{array}$ & $\begin{array}{l}\text { Análise } \\
\text { Estatística }\end{array}$ & Resultado da Análise Estatística Inferencial & Conclusão \\
\hline $\begin{array}{l}\text { TASol - adensador por } \\
\text { flotação }\end{array}$ & Manutenção da média & $\begin{array}{l}\text { Teste de Variância } \\
\text { e Teste de Médias }\end{array}$ & $\begin{array}{c}\text { Variáveis em que as médias e as variâncias } \\
\text { são iguais. }\end{array}$ & $\begin{array}{l}\text { Houve de fato a manutenção } \\
\text { indicada pela estatística } \\
\text { descritiva }\end{array}$ \\
\hline Vazão de Lodo Flotado (L/s) & $\begin{array}{l}\text { Diminuição no período } \\
\text { com lodo }\end{array}$ & $\begin{array}{l}\text { Teste de Variância } \\
\text { e Teste de Médias }\end{array}$ & $\begin{array}{l}\text { Variância amostral obteve aumento } \\
\text { significativo no período com lodo comparado } \\
\text { ao período controle; médias são diferentes e } \\
\text { tal métrica teve diminuição com a adição do } \\
\text { Lodo. }\end{array}$ & $\begin{array}{l}\text { Houve de fato a diminuição } \\
\text { indicada pela estatística } \\
\text { descritiva }\end{array}$ \\
\hline SST - Lodo Flotado (mg/L) & Manutenção da média & $\begin{array}{l}\text { Regressão } \\
\text { Robusta }\end{array}$ & $\begin{array}{l}\text { Níveis médios diferentes, com tendência de } \\
\text { diminuição no período "Lodo". }\end{array}$ & $\begin{array}{l}\text { A mudança indicada pela } \\
\text { estatística descritiva não é } \\
\text { significativa }\end{array}$ \\
\hline SSV - Lodo Flotado (mg/L) & Manutenção da média & $\begin{array}{l}\text { Regressão } \\
\text { Robusta }\end{array}$ & $\begin{array}{l}\text { Níveis médios diferentes, com tendência de } \\
\text { diminuição no período "Lodo". }\end{array}$ & $\begin{array}{l}\text { A mudança indicada pela } \\
\text { estatística descritiva não é } \\
\text { significativa }\end{array}$ \\
\hline $\begin{array}{l}\text { Vazão de Lodo Digerido } \\
\text { (L/s) }\end{array}$ & $\begin{array}{l}\text { Aumento no período } \\
\text { com lodo }\end{array}$ & $\begin{array}{l}\text { Teste de Variância } \\
\text { e Teste de Médias }\end{array}$ & $\begin{array}{l}\text { Variância igual em ambos os períodos; } \\
\text { médias são diferentes e tal métrica teve } \\
\text { aumento com a adição do Lodo. }\end{array}$ & $\begin{array}{l}\text { Houve de fato o aumento } \\
\text { indicado pela estatística } \\
\text { descritiva }\end{array}$ \\
\hline ST - Lodo Digerido (mg/L) & Manutenção da média & $\begin{array}{l}\text { Regressão } \\
\text { Robusta }\end{array}$ & $\begin{array}{l}\text { Níveis médios diferentes, com tendência de } \\
\text { diminuição no período "Lodo". }\end{array}$ & $\begin{array}{l}\text { A manutenção indicada pela } \\
\text { estatística descritiva não é real, } \\
\text { ocorrendo uma diminuição da } \\
\text { média no período com lodo }\end{array}$ \\
\hline SV - Lodo Digerido (mg/L) & Manutenção da média & $\begin{array}{l}\text { Regressão } \\
\text { Robusta }\end{array}$ & $\begin{array}{l}\text { Tendência de aumento no período "Controle", } \\
\text { no período "Lodo" há tendência de diminuição. }\end{array}$ & $\begin{array}{l}\text { A manutenção indicada pela } \\
\text { estatística descritiva não é real, } \\
\text { ocorrendo uma diminuição da } \\
\text { média no período com lodo }\end{array}$ \\
\hline $\begin{array}{l}\text { Tempo de detenção - } \\
\text { digestores }\end{array}$ & $\begin{array}{l}\text { Diminuição no período } \\
\text { com lodo }\end{array}$ & $\begin{array}{l}\text { Teste de Variância } \\
\text { e Teste de Médias }\end{array}$ & $\begin{array}{l}\text { Variância amostral obteve aumento } \\
\text { significativo no período com lodo comparado } \\
\text { ao período controle; médias são diferentes e } \\
\text { tal métrica teve diminuição com a adição do } \\
\text { Lodo. }\end{array}$ & $\begin{array}{c}\text { Houve de fato a diminuição } \\
\text { indicada pela estatística } \\
\text { descritiva }\end{array}$ \\
\hline
\end{tabular}

Continua. 
Tabela 18 - Resumo das Análises Estatísticas (conclusão).

\begin{tabular}{|c|c|c|c|c|}
\hline Variável & $\begin{array}{l}\text { Resultado da Análise } \\
\text { Estatística Descritiva }\end{array}$ & $\begin{array}{l}\text { Análise } \\
\text { Estatística }\end{array}$ & $\begin{array}{l}\text { Resultado da Análise Estatística } \\
\text { Inferencial }\end{array}$ & Conclusão \\
\hline $\begin{array}{l}\text { Produção de gás - } \\
\text { digestores }\end{array}$ & $\begin{array}{l}\text { Aumento significativo no } \\
\text { período com lodo }\end{array}$ & $\begin{array}{l}\text { Teste de Variância } \\
\text { e Teste de Médias }\end{array}$ & $\begin{array}{l}\text { Variância igual em ambos os períodos; } \\
\text { médias são diferentes e tal métrica teve } \\
\text { aumento com a adição do Lodo. }\end{array}$ & $\begin{array}{l}\text { Houve de fato o aumento } \\
\text { indicado pela estatística } \\
\text { descritiva }\end{array}$ \\
\hline $\begin{array}{l}\text { Remoção de SV - } \\
\text { digestores }\end{array}$ & $\begin{array}{l}\text { Aumento no período com } \\
\text { lodo }\end{array}$ & $\begin{array}{l}\text { Teste de Variância } \\
\text { e Teste de Médias }\end{array}$ & $\begin{array}{c}\text { Variáveis em que as médias e as variâncias } \\
\text { são iguais. }\end{array}$ & $\begin{array}{l}\text { Houve de fato a manutenção } \\
\text { indicada pela estatística } \\
\text { descritiva }\end{array}$ \\
\hline $\begin{array}{l}\text { Produção de gás por } \\
\text { remoção de SV (m³/kg) }\end{array}$ & Manutenção da média & $\begin{array}{l}\text { Teste de Variância } \\
\text { e Teste de Médias }\end{array}$ & $\begin{array}{l}\text { Variância igual em ambos os períodos; } \\
\text { médias são diferentes e tal métrica teve } \\
\text { aumento com a adição do Lodo. }\end{array}$ & $\begin{array}{l}\text { Houve de fato a manutenção } \\
\text { indicada pela estatística } \\
\text { descritiva }\end{array}$ \\
\hline $\begin{array}{l}\text { Consumo de } \mathrm{CaO} \text { - } \\
\text { condicionamento }\end{array}$ & $\begin{array}{l}\text { Aumento significativo no } \\
\text { período com lodo }\end{array}$ & $\begin{array}{l}\text { Teste de Variância } \\
\text { e Teste de Médias }\end{array}$ & $\begin{array}{l}\text { Variância amostral obteve aumento } \\
\text { significativo no período com lodo comparado } \\
\text { ao período controle; médias são diferentes e } \\
\text { tal métrica teve aumento com a adição do } \\
\text { Lodo. }\end{array}$ & $\begin{array}{l}\text { Houve de fato o aumento } \\
\text { indicado pela estatística } \\
\text { descritiva }\end{array}$ \\
\hline $\begin{array}{l}\text { Consumo de } \mathrm{FeCl}_{3}- \\
\text { condicionamento }\end{array}$ & $\begin{array}{l}\text { Aumento no período com } \\
\text { lodo }\end{array}$ & $\begin{array}{l}\text { Teste de Variância } \\
\text { e Teste de Médias }\end{array}$ & $\begin{array}{l}\text { Variância igual em ambos os períodos; } \\
\text { médias são diferentes e tal métrica teve } \\
\text { aumento com a adição do Lodo. }\end{array}$ & $\begin{array}{l}\text { Houve de fato o aumento } \\
\text { indicado pela estatística } \\
\text { descritiva }\end{array}$ \\
\hline Produção final de lodo (t/d) & $\begin{array}{l}\text { Aumento significativo no } \\
\text { período com lodo }\end{array}$ & $\begin{array}{l}\text { Teste de Variância } \\
\text { e Teste de Médias }\end{array}$ & $\begin{array}{l}\text { Variância igual em ambos os períodos; } \\
\text { médias são diferentes e tal métrica teve } \\
\text { aumento com a adição do Lodo. }\end{array}$ & $\begin{array}{l}\text { Houve de fato o aumento } \\
\text { indicado pela estatística } \\
\text { descritiva }\end{array}$ \\
\hline $\begin{array}{l}\text { Teor de sólidos - Lodo } \\
\text { desidratado final (\%) }\end{array}$ & Manutenção da média & $\begin{array}{l}\text { Teste de Variância } \\
\text { e Teste de Médias }\end{array}$ & $\begin{array}{l}\text { Variância amostral obteve aumento } \\
\text { significativo no período com lodo comparado } \\
\text { ao período controle; médias são iguais } \\
\text { comparando os dois períodos. }\end{array}$ & $\begin{array}{l}\text { Houve de fato a manutenção } \\
\text { indicada pela estatística } \\
\text { descritiva }\end{array}$ \\
\hline
\end{tabular}


Pode-se afirmar que, para a grande maioria das variáveis, as observações feitas através das medidas estatísticas e dos gráficos box-plot foram confirmadas ou pela regressão ou pelos testes de hipótese. Para algumas variáveis, porém, os testes indicaram resultados diferentes, a saber:

- DQO afluente, eficiência de remoção total NTK, N-NH 3 final, eficiência de remoção total de $\mathrm{N}-\mathrm{NH}_{3}$, eficiência de remoção total de $\mathrm{Fe}$, DBO primário, eficiência de remoção de SST e SSV no tratamento primário, e Fe primário: as variações sutis observadas nos dados não constituem modificações significativas de um período para o outro, isto é, no período com lodo tais variáveis se mantiveram tal como no período controle;

- SSV no lodo primário, SST no lodo adensado, SSV e SST no lodo flotado, e ST e SV no lodo digerido: pelos box-plot aparentemente não houve mudança de um período para outro, porém ao se analisar a tendência, observa-se que no período com lodo houve uma diminuição nos valores da variável;

- TAS no decantador secundário: pela análise do box-plot, a média se manteve de um período para o outro, porém os testes indicam que houve um aumento no seu valor no período com lodo. 


\section{CONCLUSÕES E RECOMENDAÇÕES}

A partir das análises realizadas, pode-se concluir que:

I. A contribuição do lodo da ETA alterou as qualidades do esgoto bruto afluente ao tratamento na ETE $A B C$, verificada pelas concentrações de matéria orgânica (medida em termos de DBO), sólidos (SST e SSV), fósforo e ferro totais. Para as duas últimas, observaram-se as maiores alterações relativas a concentração afluente de ferro quintuplicou, enquanto para o fósforo houve aumento próximo de $50 \%$. Em termos de sólidos, o aumento de concentração no período com lodo foi majorado também por fator externo ao lançamento de lodo da ETA. Além disso, observou-se uma diminuição na relação SSVISST (de $66 \%$ para $61 \%$ ), pelo maior aporte de material inorgânico contido no lodo da ETA. No tocante às concentrações de DQO e nitrogênio (amoniacal e total), não se observou alterações significativas de qualidade no esgoto afluente à $E T E A B C$ no período com lodo, sendo isto já esperado para o caso do nitrogênio.

II. A remoção global de sólidos ao longo do tratamento de fase líquida aumentou com o lançamento de lodo da ETA, acarretando em concentrações aproximadamente $30 \%$ menores de sólidos no efluente final, mesmo com o aumento da concentração no esgoto afluente. Nos decantadores primários, as eficiências de remoção de sólidos mantiveram-se as mesmas que no período controle, acarretando em maiores concentrações no efluente primário. Nos tanques de aeração, o processo biológico não sofreu prejuízos com o recebimento do lodo da ETA em termos de crescimento microbiológico, uma vez que as concentrações de sólidos nestes tanques apresentaram aumento mais acentuado no período com lodo que no período controle, ultrapassando $4.000 \mathrm{mg} / \mathrm{L}$. Em relação aos decantadores secundários, mesmo com o aumento da vazão e quantidade de sólidos afluentes, houve melhoria na remoção de sólidos, apresentada pela melhor qualidade do efluente final - as 
taxas de aplicação (superficial e de sólidos) apresentaram aumento, porém se mantiveram ainda abaixo dos valores de projeto e norma.

III. A remoção de material orgânico pelo tratamento de fase líquida da ETE, avaliado pelas concentrações de DBO e de DQO sofreu alterações semelhantes ao caso dos sólidos: houve maiores eficiências de remoção no período com lodo, uma vez que se aumentaram as concentrações no esgoto afluente e se manteve a qualidade do efluente final no tocante à DBO e DQO, quando comparado com o período controle. $O$ aumento na eficiência de remoção se deve ao tratamento secundário (tanques de aeração mais decantadores secundários), uma vez que o tratamento primário se manteve com as mesmas características - concentração no efluente primário e eficiência de remoção nos decantadores - em ambos os períodos. Vê-se, portanto, que não ocorreu qualquer inibição do tratamento biológico na ETE, acarretando inclusive em lodo com melhores características de sedimentação nos decantadores secundários (aumento de IVL até $120 \mathrm{~mL} / \mathrm{g}$, mantendo-se ainda abaixo de valores limites encontrados na literatura). Nos tanques de aeração houve manutenção da idade do lodo de um período para o outro, e aumento aceitável na relação $\mathrm{A} / \mathrm{M}$.

IV. Em relação ao nitrogênio, pode-se afirmar que as remoções das formas analisadas (amoniacal e total) não foram influenciadas de forma alguma com o lançamento de lodo da ETA Rio Grande na ETE ABC, uma vez que praticamente mantiveram-se em ambos os períodos as concentrações afluentes e efluentes nas unidades de tratamento primário e secundário da fase líquida na ETE, com consequente manutenção das eficiências de cada unidade - médias acima de $80 \%$ de remoção global, mesmo a ETE não tendo sido projetada para ocorrência de nitrificação e desnitrificação.

V. Para a variável de qualidade fósforo total, observou-se as melhorias de remoção conforme indicado na literatura: mesmo com o aumento em quase $50 \%$ de concentração afluente, advindo com o lodo da ETA Rio Grande no período em que houve o recebimento deste, as concentrações no efluente final da ETE diminuíram significativamente no período com lodo - média de 
0,7 $\mathrm{mg} / \mathrm{L}$, contra $2,7 \mathrm{mg} / \mathrm{L}$ no período controle. O tratamento primário apresentou aumento na eficiência de remoção de fósforo no segundo período, diminuindo a maior concentração afluente até o mesmo nível de qualidade do efluente primário do período controle.

VI. A concentração de ferro total afluente aumentou cinco vezes no período com lodo, advindo do coagulante utilizado na ETA Rio Grande (sulfato férrico). A eficiência de remoção global de ferro no tratamento de fase líquida da ETE $A B C$ se manteve praticamente a mesma nos dois períodos, impactando assim na concentração de ferro no efluente final, a qual também foi maior no segundo período. Em relação ao tratamento primário, a eficiência de remoção nos decantadores aumentou no período com lodo (de 30\% para 60\%), garantindo a manutenção das concentrações no efluente primário.

VII. Em termos de taxa de aplicação superficial nos decantadores primários, sua média não sofreu alterações significativas de um período para outro, continuando em torno de $35 \mathrm{~m} / \mathrm{m}^{2}$.dia, abaixo dos valores de projeto e dos recomendados pela literatura. Com isso, não se pode afirmar que ocorreram prejuízos operacionais nos decantadores primários com o lançamento do lodo da ETA.

VIII. No tratamento secundário, não se observou nos tanques de aeração qualquer inibição dos processos biológicos do período controle no período com lodo, ocorrendo aumento da concentração de sólidos nos reatores, na relação $A / M$ e no IVL, mas ainda operando nas faixas indicadas na literatura -, além da manutenção da idade do lodo. Para os decantadores secundários, houve aumento da TAS e da TASol no período com lodo, mas os valores destas variáveis - $20 \mathrm{~m} / \mathrm{m}^{2}$.dia e $80 \mathrm{~kg} / \mathrm{m}^{2}$.dia, respectivamente - ainda se mantiveram bastante abaixo dos limites máximos estabelecidos em norma.

IX. O maior aporte de sólidos no afluente à ETE no período com lodo e o aumento da eficiência de remoção dos decantadores primários destes sólidos acarretaram em uma maior geração volumétrica de lodo primário (vazão em L/s), com a qual se percebeu diminuição tanto na concentração de SST 
quanto de SSV neste período, ou seja, obteve-se um lodo mais diluído, conforme esperado. Além disso, no período com lodo foi observada maior vazão de lodo adensado por gravidade, com indícios de diminuição no teor de sólidos do mesmo, em termos de SST. Porém, não se pode atribuir como causa desta diminuição de performance dos adensadores o aumento tanto da sua TAS quanto da sua TASol, uma vez que os valores de teor de sólidos resultante se mantiveram acima dos $3 \%$ e as taxas também se mantiveram abaixo dos limites máximos de projeto da ETE, os quais respeitam a norma brasileira e a literatura.

X. O aumento na concentração de sólidos nos tanques de aeração e a manutenção da idade do lodo em torno de 4 dias na operação destes biorreatores durante o período com lodo levaram a uma maior geração de lodo secundário nos decantadores circulares, implicando em maiores vazões de recirculação e de descarte de lodo. Com isso, os flotadores passaram a receber maior carga de sólidos, mas a qual não alterou de maneira significativa a TASol, de modo que o desempenho da unidade se manteve como no período controle, com teor de sólidos no lodo flotado da ordem de $2,5 \%$. Uma vez que se manteve o TS no lodo flotado, mesmo com o aumento da vazão de lodo afluente aos flotadores, ocorreu, então, uma diminuição na vazão volumétrica deste lodo efluente.

XI. Em relação aos digestores, como o aporte de lodo adensado, somatória das parcelas adensada por gravidade e por flotação, aumentou no período com lodo, observou-se como consequência uma maior vazão de lodo digerido, bem como uma diminuição no tempo de detenção nos digestores de 48 dias para 32 dias. Porém, mesmo com esta diminuição, a performance dos digestores não foi prejudicada em relação ao observado no período controle, ocorrendo a manutenção da eficiência de remoção de SV, inclusive com maior tendência de diminuição das concentrações de SV e ST no lodo digerido no período com lodo, praticamente dobrando a produção de gás.

XII. Por fim, observou-se no período com lodo o aumento no consumo de produtos químicos em relação ao período controle, decorrente da maior vazão 
afluente ao sistema de condicionamento e desidratação, sendo este aumento mais significativo para a cal - praticamente dobrou-se o consumo. $\mathrm{Na}$ desidratação, houve manutenção dos valores médios de teor de sólidos na torta, próximos de $40 \%$, decorrendo disto também uma maior produção mássica final de torta na desidratação.

A partir disso, pode-se afirmar que o lançamento de lodo da ETA Rio Grande não causou impactos significativos nos processos de tratamento e qualidade do efluente final da ETE ABC, durante o período analisado (janeiro de 2007 a março de 2008). Isto fornece indícios de que esta prática de disposição de lodo de ETA em ETE pode ser aplicada em outras instalações que apresentem as características das estações estudadas, isto é, processo de tratamento convencional de água e processo de tratamento de esgotos por lodos ativados, estando a ETE com folga na capacidade tanto de volume de esgoto recebido quanto de sólidos.

Destaca-se novamente o fato de a ETA Rio Grande apresentar vazão de tratamento de praticamente o triplo da vazão operante na ETE ABC. A importância disto reside no fato de este diferencial de portes não ter influído na magnitude dos impactos causados no processo de tratamento na ETE advindos do recebimento de grande quantidade relativa de lodo da ETA, o que indica tal aplicação em, por exemplo, municípios em que haja apenas uma ETA e uma ETE, de modo que suas vazões são praticamente iguais (salvo parcela de retorno e infiltrações). Novamente, são casos bastante frequentes no Brasil, que podem ter melhor destinação dos lodos, evitando a disposição e sobrecarga em aterros sanitários.

Porém, deve-se atentar para a qualidade do lodo final da ETE. Como a aplicação de lodo da ETA traz melhorias na remoção de componentes do esgoto principalmente nas unidades de sedimentação primária, via arraste e adsorção nos flocos, há maior chance de remoção principalmente de metais, que concentrados no lodo final inviabilizam a sua aplicação, por exemplo, na agricultura. Além disso, espera-se que a quantidade de metais no lodo final seja maior pela simples contribuição do lodo da ETA - vide resultados obtidos para o ferro -, uma vez que este lodo é composto em grande parte pelos produtos químicos aplicados no tratamento de água coagulantes, alcalinizantes e coadjuvantes de coagulação/floculação (polímeros) os quais podem apresentar impurezas. 
Recomendam-se, então, estudos mais aprofundados deste tema (caracterização do lodo) bem como sobre a destinação do fósforo removido e sua especiação, uma vez que se acredita que este foi meramente transferido da fase líquida na fase sólida na forma de fosfato precipitado. O estudo de destinação do fósforo pode levar em conta, inclusive, a análise da composição do lodo da ETA e também do floco biológico formado no tanque de aeração da ETE, a fim de se analisar a magnitude da adsorção do fósforo nos mesmos. 


\section{REFERÊNCIAS}

ABNT - Associação Brasileira de Normas Técnicas. NBR 10.004: Classificação de Resíduos Sólidos. Rio de Janeiro, 1987.

ABNT - Associação Brasileira de Normas Técnicas. NBR 12.209: Projeto de Estações de Tratamento de Esgoto Sanitário. Rio de Janeiro, 1992.

ALVAREZ ROSÁRIO, C. G. Avaliação da disposição do lodo gerado numa estação de tratamento de água em reator anaeróbio de fluxo ascendente e manto de lodo (UASB). 2007. 236 p. Dissertação (Mestrado) - Escola Politécnica da Universidade de São Paulo, São Paulo, 2007.

ALENCAR, A. P., CHIANN, C., ANDRADE, J., SILVA, P. G., (2011) Relatório de análise estatística sobre o projeto: "Efeito do recebimento de lodos oriundos de estações de tratamento de água nos processos de tratamento de esgotos por lodos ativados convencional”. São Paulo. IME-USP, (RAE-CEA-11P20).

ANDREOLI, C. V. Resíduos Sólidos do saneamento: processamento, reciclagem e disposição final. Rio de Janeiro: Rima/ABES, 2001. xxiv, 257 p. (Projeto PROSAB).

ANDREOLI, C. et al. Lodos de Esgoto: Tratamento e Disposição Final. $1^{\text {a }}$ ed. rev. Belo Horizonte: DESA/UFMG, 2001. v. 6.

ASADA, L. N. Avaliação dos efeitos do recebimento do lodo de estação de tratamento de água em sistema de tratamento de esgoto pelo processo de lodo ativado com aeração prolongada. 2007. 189 p. Dissertação (Mestrado) - Escola Politécnica da Universidade de São Paulo, São Paulo, 2007.

AWWA - American Water Works Association. Water quality and treatment a handbook of community water supplies. 5th ed. New York, McGrawHill, c1999. 1 v.

AMERICAN SOCIETY OF CIVIL ENGINEERS. American Water Works Association. US Environmental Protection Agency. Management of water treatment plant residuals: technology transfer handbook. New York, NY; Denver, CO : American Society of Civil Engineers: American Water Works Association, c1996. Xxv, 294 p. (ASCE manuals and reports of engineering practice, $n .88$ ). 
BABATUNDE, A. Q., ZHAO, Y. Q. Constructive approaches toward water treatment works sludge management: An international review of beneficial reuses. Critical Reviews in Environmental Science and Technology. n. 37, p. 129164, 2007.

BABATUNDE, A. Q. et al. Characterization of aluminium-based water treatment residual for potential phosphorus removal in engineered wetlands.

Environmental Pollution. n. 157, p. 2830-2836, 2009.

BUENO et al. Estudo em escala real da operação da ETE Franca com recebimentos de lodo da ETA Norte (Franca, SP). In: $24^{\circ}$ Congresso Brasileiro de Engenharia Sanitária e Ambiental, Belo Horizonte. Anais. ABES. 2007.

BUSSAB, W.O e MORETTIN, P.A. Estatística Básica. São Paulo: Editora Saraiva, 2006.

CARVALHO, E. H. Disposição de resíduos gerados nas estações de tratamento de água em estações de tratamento de esgoto com decantação primária. 2000. 171 p. Tese (Doutorado) - Escola de Engenharia de São Carlos, Universidade de São Paulo, São Carlos, 2000.

CONAMA - CONSELHO NACIONAL DO MEIO AMBIENTE. Resolução n. 357, de 17 de março de 2005. Dispõe sobre a classificação dos corpos de água e diretrizes ambientais para o seu enquadramento, bem como estabelece as condições e padrões de lançamento de efluentes, e dá outras providências. Disponível em: <www.mma.gov.br/port/conama/res/res05/res35705.pdf>. Acesso em: 30 nov. 2010.

CONAMA - CONSELHO NACIONAL DO MEIO AMBIENTE. Resolução n. 430, de 13 de maio de 2011. Dispõe sobre condições e padrões de lançamento de efluentes, complementa e altera a Resolução no 357, de 17 de março de 2005, do Conselho Nacional do Meio Ambiente - CONAMA. Disponível em:

<http://www.mma.gov.br/port/conama/legiabre.cfm?codlegi=646>. Acesso em: 30 nov. 2010.

CORDEIRO, J. S., CAMPOS, J. R. O impacto ambiental provocado pela indústria da água de abastecimento. Saneamento Ambiental, São Paulo, v. 10, n. 56, p. 5257, mar./abr. 1999.

CORNWELL, D. A. American Water Works Association Foundation. Water Treatment plant waste management. Denver, CO: AWWA Research Foundation, 1987, xx, 459 p. 
DI BERNARDO, L. Métodos e técnicas de tratamento de água. $2^{\mathrm{a}}$ ed. São Carlos: Rima/ABES, 2005. v. 1 e v. 2.

ENCIBRA S. A. Estudos e Projetos de Engenharia; HIDROCONSULT Consultoria, Estudos e Projetos S.A. Revisão e Atualização do Plano Diretor de Abastecimento de Água da RMSP. São Paulo: Estudo Técnico ENCIBRAHIDROCONSULT/SABESP, 2004.

FERREIRA FILHO, S. S. Avaliação e Diagnóstico da Estação de Tratamento de Água do Rio Grande. São Paulo: Escola Politécnica da Universidade de São Paulo, 2006.

FERREIRA FILHO, S. S.; ALEM SOBRINHO, P. Considerações sobre o tratamento de despejos líquidos gerados em estações de tratamento de água. Revista Engenharia Sanitária e Ambiental, Rio de Janeiro, v. 3, n. 3/4, p. 128-136, jul/dez. 1998.

HIDROSERVICE. Manual Operacional da ETE ABC. São Paulo: HIDROSERVICE, 1998.

HORAN, N. J. Biological Wastewater Treatment systems: theory and operation. Chichester; New York: Wiley, 1990. viii, 310 p.

HUBER, P.J. Robust Statistics. Wiley. 1981

JANUÁRIO, G. F. Planejamento e aspectos ambientais envolvidos na disposição final de lodos de estações de tratamento de água da região metropolitana de São Paulo. 2005. 222 p. Dissertação (Mestrado) - Escola Politécnica da Universidade de São Paulo, São Paulo, 2005.

JANUÁRIO, G. F.; FERREIRA FILHO, S.S. Planejamento e aspectos ambientais envolvidos na disposição final de lodos das estações de tratamento de água da região metropolitana de São Paulo. Revista Engenharia Sanitária e Ambiental, Rio de Janeiro, v. 12, n. 2, p. 117-126, abr./jun. 2007.

METCALF \& EDDY. Wastewater engineering: treatment and reuse. $4^{\text {th }}$ ed. Boston; London: McGraw-Hill, c2003. xxviii, 1819 p.

SABESP. Estação de Tratamento de Esgotos ABC - folder. São Paulo: SABESP, 2005a. 
SABESP. Relatório Gerencial da ETE ABC - jan/05 a dez/05. São Paulo:

SABESP, 2005b. SABESP, 2006.

Relatório Gerencial da ETE ABC - jan/06 a dez/06. São Paulo: SABESP, 2007.

Relatório Gerencial da ETE ABC - jan/07 a dez/07. São Paulo:

SABESP, 2008.

Relatório Gerencial da ETE ABC - jan/08 a dez/08. São Paulo:

SÃO PAULO (Estado). Decreto no 8.468, de 08 de setembro de 1976. Aprova o Regulamento da Lei $n^{\circ}$ 997, de 31 de maio de 1976, que dispõe sobre a prevenção e o controle da poluição do meio ambiente. Disponível em:

$<$ http://www.cetesb.sp.gov.br/Servicos/licenciamento/postos/legislacao/Decreto_Esta dual_8468_76.pdf>. Acesso em: 30 nov. 2010.

SARON, A.; LEITE, V. M. B. Quantificação de lodo em estação de tratamento de Água. In: $21^{\circ}$ Congresso Brasileiro de Engenharia Sanitária e Ambiental, João Pessoa. Anais. ABES. 2001.

SCALIZE, P. S. Disposição de resíduos gerados em estações de tratamento de água em estações de tratamento de esgoto. 2003. 146 p. Tese (Doutorado) Escola de Engenharia de São Carlos, Universidade de São Paulo, São Carlos, 2003.

SCALIZE, E. H., DI BERNARDO, L. Estudo das interferências ocorridas em digestores anaeróbios de lodo primário de estações de tratamento de esgotos após receber resíduos de estação de tratamento de água. In: $25^{\circ}$ Congresso Brasileiro de Engenharia Sanitária e Ambiental, Recife. Anais. ABES. 2009.

SCALIZE, E. H., DI BERNARDO, L. Estudo em escala piloto da disposição em uma ETE de resíduos de ETA que utiliza cloreto férrico como coagulante. In: $25^{\circ}$ Congresso Brasileiro de Engenharia Sanitária e Ambiental, Recife. Anais. ABES. 2009.

SUNDEFELD, G. C. Efeitos do recebimento do lodo da estação de tratamento de água pelo sistema de tratamento de esgoto por lodo ativado em bateladas e aeração prolongada do município de Juquitiba - SP. 2007. 107 p. Dissertação (Mestrado) - Escola Politécnica da Universidade de São Paulo, São Paulo, 2007. 
VAN HAANDEL, A. C., MARAIS, G. O Comportamento do Sistema de Lodos Ativados: Teoria e Aplicações para Projetos e Operação. Campina Grande, PB: Efgraf, 1999. $472 \mathrm{p}$.

VON SPERLING, M. Lodos Ativados: Princípios do tratamento biológico de água residuárias. $2^{\mathrm{a}}$ ed. Belo Horizonte: DESA/UFMG, 2002. v. 4.

ZHAO, Y. Q. et al. Use of dewatered alum sludge as main substrate in treatment reed bed receiving agricultural wastewater: long-term trial. Bioresource Technology. n. 100, p. 644-648, 2008. 
ANEXO A - DADOS UTILIZADOS - FASE LÍQUIDA 
Tabela 19 - Dados Mensais da Fase Líquida.

\begin{tabular}{|c|c|c|c|c|c|c|c|c|c|c|c|c|c|c|c|c|c|}
\hline DATA & $\begin{array}{l}\text { Vazão } \\
\left(\mathrm{m}^{3} / \mathbf{s}\right)\end{array}$ & $\begin{array}{c}\text { SST } \\
\text { afluente } \\
\text { (mg/L) }\end{array}$ & $\begin{array}{c}\text { SST } \\
\text { efluente } \\
\text { primário } \\
\text { (mg/L) }\end{array}$ & $\begin{array}{c}\text { eficiência de } \\
\text { remoção SST - } \\
\text { decantador } \\
\text { primário }(\%) \\
\end{array}$ & $\begin{array}{l}\text { SST tanque } \\
\text { de aeraçãa } \\
\text { (mg/L) }\end{array}$ & $\begin{array}{c}\text { SST } \\
\text { efluente } \\
\text { final (mg/L) }\end{array}$ & $\begin{array}{c}\text { eficiência de } \\
\text { remoçãoo } \\
\text { total na ETE - } \\
\text { SST (\%) } \\
\end{array}$ & $\begin{array}{c}\text { SSV } \\
\text { afluente } \\
\text { (mg/L) }\end{array}$ & $\begin{array}{l}\text { SSV } \\
\text { efluente } \\
\text { primário } \\
\text { (mg/L) }\end{array}$ & $\begin{array}{c}\text { eficiência de } \\
\text { remoção SSV - } \\
\text { decantador } \\
\text { primário (\%) }\end{array}$ & $\begin{array}{l}\text { SSV tanque } \\
\text { de aeração } \\
\text { (mg/L) }\end{array}$ & $\begin{array}{c}\text { SSV } \\
\text { efluente } \\
\text { final } \\
\text { (mg/L) }\end{array}$ & $\begin{array}{l}\text { eficiência de } \\
\text { remoção } \\
\text { total na ETE } \\
\text { - SSV (\%) }\end{array}$ & $\begin{array}{l}\text { SSVISST } \\
\text { afluente }\end{array}$ & $\begin{array}{c}\text { DBO } \\
\text { afluente } \\
\text { (mg/L) }\end{array}$ & $\begin{array}{c}\text { DBO } \\
\text { efluente } \\
\text { primário } \\
\text { (mg/L) }\end{array}$ & $\begin{array}{c}\text { eficiênncia de } \\
\text { remoção DBO } \\
\text { - decantador } \\
\text { primário (\%) }\end{array}$ \\
\hline jan-05 & 1,248 & 255 & 155 & $39 \%$ & 3.015 & 19 & $93 \%$ & 173 & 100 & $42 \%$ & 1.799 & 13 & $92 \%$ & $68 \%$ & 147 & 91 & $38 \%$ \\
\hline fev-05 & 1,213 & 243 & 158 & $35 \%$ & 3.023 & 19 & $92 \%$ & 160 & 99 & $38 \%$ & 1.839 & 10 & $94 \%$ & $66 \%$ & 179 & 125 & $30 \%$ \\
\hline mar-05 & 1,191 & 358 & 206 & $42 \%$ & 3.880 & 18 & $95 \%$ & 218 & 123 & $44 \%$ & 2.311 & 11 & $95 \%$ & $61 \%$ & 172 & 142 & $17 \%$ \\
\hline abr-05 & 1,269 & 278 & 225 & $19 \%$ & 3.300 & 18 & $94 \%$ & 163 & 142 & $13 \%$ & 2.012 & 10 & $94 \%$ & $59 \%$ & 178 & 134 & $25 \%$ \\
\hline mai-05 & 1,243 & 270 & 138 & $49 \%$ & 2.553 & 23 & $91 \%$ & 172 & 90 & $48 \%$ & 1.732 & 15 & $91 \%$ & $64 \%$ & 212 & 115 & $46 \%$ \\
\hline jun-05 & 1,331 & 246 & 129 & $48 \%$ & 2.486 & 22 & $91 \%$ & 161 & 90 & $44 \%$ & 1.782 & 14 & $91 \%$ & $65 \%$ & 354 & 110 & $69 \%$ \\
\hline jul-05 & 1,309 & 294 & 152 & $48 \%$ & 3.126 & 19 & $94 \%$ & 206 & 104 & $50 \%$ & 2.298 & 11 & $95 \%$ & $70 \%$ & 331 & 133 & $60 \%$ \\
\hline ago-05 & 1,145 & 378 & 194 & $49 \%$ & 3.654 & 20 & $95 \%$ & 244 & 123 & $50 \%$ & 2.641 & 12 & $95 \%$ & $65 \%$ & & & \\
\hline set-05 & 1,231 & & & & 5.349 & & & & & & 3.689 & & & & 392 & 237 & $40 \%$ \\
\hline out-05 & 1,345 & 289 & 206 & $29 \%$ & 5.663 & 16 & $94 \%$ & 194 & 131 & $32 \%$ & 3.836 & 10 & $95 \%$ & $67 \%$ & 285 & 164 & $42 \%$ \\
\hline nov-05 & 1,335 & 295 & 233 & $21 \%$ & 4.871 & 15 & $95 \%$ & 193 & 145 & $25 \%$ & 3.281 & 9 & $95 \%$ & $65 \%$ & 293 & 174 & $41 \%$ \\
\hline dez-05 & 1,385 & 359 & 287 & $20 \%$ & & 19 & $95 \%$ & 243 & 165 & $32 \%$ & & 12 & $95 \%$ & $68 \%$ & 239 & 152 & $36 \%$ \\
\hline jan-06 & 1,300 & 239 & 139 & $42 \%$ & 4.647 & 13 & $95 \%$ & 149 & 91 & $39 \%$ & 2.834 & 9 & $94 \%$ & $62 \%$ & 186 & 109 & $41 \%$ \\
\hline fev-06 & 1,395 & 240 & 142 & $41 \%$ & 3.571 & 15 & $94 \%$ & 157 & 87 & $45 \%$ & 2.169 & 10 & $94 \%$ & $65 \%$ & 136 & 93 & $32 \%$ \\
\hline mar-06 & 1,399 & 168 & 101 & $40 \%$ & 3.157 & 19 & $89 \%$ & 109 & 68 & $38 \%$ & 2.105 & 13 & $88 \%$ & $65 \%$ & 122 & 77 & $37 \%$ \\
\hline abr-06 & 1,448 & 190 & 122 & $36 \%$ & 3.267 & 19 & $90 \%$ & 134 & 91 & $32 \%$ & 2.171 & 13 & $90 \%$ & $71 \%$ & 149 & 92 & $38 \%$ \\
\hline mai-06 & 1,356 & 273 & 132 & $52 \%$ & 2.971 & 19 & $93 \%$ & 191 & 91 & $52 \%$ & 2.019 & 13 & $93 \%$ & $70 \%$ & 209 & 109 & $48 \%$ \\
\hline jun-06 & 1,258 & 279 & 114 & $59 \%$ & 2.932 & 15 & $95 \%$ & 200 & 84 & $58 \%$ & 2.202 & 11 & $95 \%$ & $72 \%$ & 192 & 136 & $29 \%$ \\
\hline jul-06 & 1,426 & 233 & 103 & $56 \%$ & 2.986 & 17 & $93 \%$ & 147 & 70 & $52 \%$ & 2.233 & 11 & $93 \%$ & $63 \%$ & 182 & 105 & $42 \%$ \\
\hline ago-06 & 1,421 & 149 & 118 & $21 \%$ & 2.836 & 10 & $93 \%$ & 99 & 81 & $18 \%$ & 2.205 & 6 & $94 \%$ & $66 \%$ & & & \\
\hline set-06 & 1,421 & & & & 3.050 & & & & & & 2.278 & & & & 199 & 107 & $46 \%$ \\
\hline out-06 & 1,402 & 350 & 238 & $32 \%$ & 4.137 & 21 & $94 \%$ & 243 & 155 & $36 \%$ & 2.839 & 14 & $94 \%$ & $69 \%$ & 232 & 145 & $38 \%$ \\
\hline nov-06 & 1,475 & 306 & 172 & $44 \%$ & 4.709 & 16 & $95 \%$ & 211 & 113 & $46 \%$ & 3.160 & 10 & $95 \%$ & $69 \%$ & 147 & 98 & $33 \%$ \\
\hline dez-06 & 1,443 & 204 & 107 & $48 \%$ & 3.234 & 16 & $92 \%$ & 126 & 73 & $42 \%$ & 2.081 & 11 & $91 \%$ & $62 \%$ & 127 & 83 & $35 \%$ \\
\hline jan-07 & 1,500 & 299 & 147 & $51 \%$ & 3.617 & 12 & $96 \%$ & 173 & 91 & $47 \%$ & 2.187 & 8 & $95 \%$ & $58 \%$ & 215 & 134 & $38 \%$ \\
\hline fev-07 & 1,554 & 285 & 166 & $42 \%$ & 3.854 & 7 & $98 \%$ & 150 & 98 & $35 \%$ & 2.209 & 4 & $97 \%$ & $53 \%$ & 171 & 137 & $20 \%$ \\
\hline mar-07 & 1,575 & 228 & 99 & $57 \%$ & 2.747 & 14 & $94 \%$ & 124 & 45 & $64 \%$ & 1.641 & 7 & $94 \%$ & $54 \%$ & 146 & 72 & $51 \%$ \\
\hline abr-07 & 1,563 & 260 & 82 & $68 \%$ & 2.231 & 11 & $96 \%$ & 168 & 56 & $67 \%$ & 1.602 & 7 & $96 \%$ & $65 \%$ & 155 & 86 & $45 \%$ \\
\hline mai-07 & 1,500 & 322 & 85 & $74 \%$ & 2.622 & 9 & $97 \%$ & 198 & 47 & $76 \%$ & 1.824 & 5 & $97 \%$ & $61 \%$ & 229 & 101 & $56 \%$ \\
\hline jun-07 & 1,514 & 342 & 145 & $58 \%$ & 3.530 & 9 & $97 \%$ & 206 & 81 & $61 \%$ & 2.368 & 6 & $97 \%$ & $60 \%$ & 298 & 154 & $48 \%$ \\
\hline jul-07 & 1,722 & 474 & 163 & $66 \%$ & 3.835 & 18 & $96 \%$ & 272 & 98 & $64 \%$ & 2.565 & 10 & $96 \%$ & $57 \%$ & 390 & 160 & $59 \%$ \\
\hline ago-07 & 1,457 & 380 & 203 & $47 \%$ & 3.994 & 9 & $98 \%$ & 255 & 133 & $48 \%$ & 2.720 & 6 & $98 \%$ & $67 \%$ & 495 & 272 & $45 \%$ \\
\hline set-07 & 1,473 & 390 & 277 & $29 \%$ & 5.264 & 17 & $96 \%$ & 243 & 180 & $26 \%$ & 3.543 & 10 & $96 \%$ & $62 \%$ & 361 & 234 & $35 \%$ \\
\hline out-07 & 1,650 & 451 & 390 & $14 \%$ & 6.835 & 12 & $97 \%$ & 286 & 246 & $14 \%$ & 4.413 & 7 & $98 \%$ & $63 \%$ & 476 & 386 & $19 \%$ \\
\hline nov- 07 & 1,453 & 414 & 225 & $46 \%$ & 5.964 & 15 & $96 \%$ & 256 & 132 & $48 \%$ & 3.585 & 8 & $97 \%$ & $62 \%$ & 363 & 235 & $35 \%$ \\
\hline dez-07 & 1,693 & 379 & 213 & $44 \%$ & 5.361 & 14 & $96 \%$ & 225 & 116 & $48 \%$ & 3.240 & 8 & $96 \%$ & $59 \%$ & 300 & 154 & $49 \%$ \\
\hline jan-08 & & 273 & 145 & $47 \%$ & 3.786 & 11 & $96 \%$ & 161 & 89 & $45 \%$ & 2.366 & 7 & $96 \%$ & $59 \%$ & 258 & 125 & $52 \%$ \\
\hline fev-08 & 1,985 & 237 & 160 & $32 \%$ & 3.457 & 11 & $95 \%$ & 160 & 108 & $33 \%$ & 2.213 & 8 & $95 \%$ & $68 \%$ & 228 & 101 & $56 \%$ \\
\hline mar-08 & 1,761 & 398 & 217 & $45 \%$ & 5.362 & 13,57 & $97 \%$ & 242 & 136 & $44 \%$ & 3.170 & 8 & $97 \%$ & $61 \%$ & 302,8 & 177 & $42 \%$ \\
\hline
\end{tabular}


Tabela 19 - Dados Mensais da Fase Líquida (cont.).

\begin{tabular}{|c|c|c|c|c|c|c|c|c|c|c|c|c|c|c|c|c|}
\hline DATA & $\begin{array}{c}\text { DQO } \\
\text { afluente } \\
\text { (mg/L) }\end{array}$ & $\begin{array}{l}\text { DQO } \\
\text { efluente } \\
\text { primário } \\
\text { (mg/L) }\end{array}$ & $\begin{array}{l}\text { eficiência de } \\
\text { remoção DQO } \\
\text { - decantador } \\
\text { primário (\%) }\end{array}$ & $\begin{array}{c}\text { DQO } \\
\text { efluente } \\
\text { final } \\
(\mathrm{mg} / \mathrm{L})\end{array}$ & $\begin{array}{l}\text { eficiência de } \\
\text { remoção } \\
\text { total na ETE } \\
\text { - DQO (\%) }\end{array}$ & $\begin{array}{c}\text { NTK } \\
\text { afluente } \\
\text { (mg/L) }\end{array}$ & $\begin{array}{c}\text { NTK } \\
\text { efluente } \\
\text { primário } \\
\text { (mg/L) }\end{array}$ & $\begin{array}{l}\text { eficiência de } \\
\text { remoção NTK } \\
\text { - decantador } \\
\text { primário (\%) }\end{array}$ & $\begin{array}{c}\text { NTK } \\
\text { efluente } \\
\text { final } \\
\text { (mg/L) }\end{array}$ & $\begin{array}{c}\text { eficiência de } \\
\text { remoção } \\
\text { total na ETE - } \\
\text { NTK (\%) }\end{array}$ & $\begin{array}{c}\mathrm{N}-\mathrm{NH}_{3} \\
\text { afluente } \\
\text { (mg/L) }\end{array}$ & $\begin{array}{c}\mathrm{N}-\mathrm{NH}_{3} \\
\text { efluente } \\
\text { final } \\
\text { (mg/L) }\end{array}$ & $\begin{array}{l}\text { eficiência de } \\
\text { remoção total na } \\
\text { ETE - N-NH } 3(\%)\end{array}$ & $\begin{array}{l}P \text { afluente } \\
\text { (mg/L) }\end{array}$ & $\begin{array}{l}\text { P efluente } \\
\text { primário } \\
\text { (mg/L) }\end{array}$ & $\begin{array}{l}\text { eficiência de } \\
\text { remoção P - } \\
\text { decantador } \\
\text { primário (\%) }\end{array}$ \\
\hline jan-05 & 270 & 222 & $18 \%$ & 35 & $87 \%$ & 25,0 & 23,7 & $5 \%$ & 3,35 & $87 \%$ & 15,00 & 2,30 & $85 \%$ & & & \\
\hline fev-05 & 374 & 272 & $27 \%$ & 38 & $90 \%$ & 30,0 & 29,6 & $1 \%$ & 1,89 & $94 \%$ & 18,10 & 0,70 & $96 \%$ & 5,0 & 4,9 & $3 \%$ \\
\hline mar-05 & 445 & 298 & $33 \%$ & 34 & $92 \%$ & 28,5 & 28,8 & $0 \%$ & 0,96 & $97 \%$ & 15,60 & 0,50 & $97 \%$ & 8,0 & 5,8 & $28 \%$ \\
\hline abr-05 & 425 & 319 & $25 \%$ & 34 & $92 \%$ & 30,6 & 32,2 & $0 \%$ & 0,9 & $97 \%$ & 19,90 & 0,78 & $96 \%$ & 4,4 & 4,4 & $0 \%$ \\
\hline mai-05 & 430 & 271 & $37 \%$ & 38 & $91 \%$ & 33,0 & 31,0 & $6 \%$ & 1,97 & $94 \%$ & 21,00 & 1,40 & $93 \%$ & 6,1 & 5,4 & $11 \%$ \\
\hline jun-05 & 425 & 255 & $40 \%$ & 40 & $91 \%$ & 41,1 & 29,4 & $28 \%$ & 1,61 & $96 \%$ & 20,00 & 0,97 & $95 \%$ & 7,1 & 5,6 & $21 \%$ \\
\hline jul-05 & 533 & 307 & $42 \%$ & 43 & $92 \%$ & 39,0 & 34,1 & $13 \%$ & 1,67 & $96 \%$ & 24,80 & 1,00 & $96 \%$ & 5,8 & 5,9 & $0 \%$ \\
\hline ago-05 & 587 & 375 & $36 \%$ & 43 & $93 \%$ & 47,8 & 42,3 & $12 \%$ & 4,55 & $90 \%$ & 24,30 & 3,66 & $85 \%$ & 6,0 & 6,4 & $0 \%$ \\
\hline set-05 & 590 & 375 & $36 \%$ & 37 & $94 \%$ & 44,7 & 34,7 & $22 \%$ & 2,15 & $95 \%$ & 20,10 & 1,10 & $95 \%$ & & & \\
\hline out-05 & 450 & 332 & $26 \%$ & 37 & $92 \%$ & 33,0 & 31,8 & $4 \%$ & 2,3 & $93 \%$ & 18,30 & 1,34 & $93 \%$ & 8,5 & 7,0 & $18 \%$ \\
\hline nov-05 & 447 & 384 & $14 \%$ & 29 & $94 \%$ & 35,2 & 35,1 & $0 \%$ & 1,86 & $95 \%$ & 19,80 & 1,83 & $91 \%$ & & & \\
\hline dez-05 & 460 & 398 & $13 \%$ & 34 & $93 \%$ & 29,4 & 29,4 & $0 \%$ & 1,78 & $94 \%$ & 19,00 & 0,84 & $96 \%$ & 5,2 & 4,6 & $12 \%$ \\
\hline jan-06 & 354 & 240 & $32 \%$ & 29 & $92 \%$ & 23,70 & 24,2 & $0 \%$ & 2,44 & $90 \%$ & 13,90 & 1,74 & $87 \%$ & 7,60 & 6,1 & $20 \%$ \\
\hline fev-06 & 369 & 244 & $34 \%$ & 31 & $92 \%$ & 31,60 & 26,0 & $18 \%$ & 7,1 & $78 \%$ & 20,40 & 6,06 & $70 \%$ & 4,00 & 3,9 & $3 \%$ \\
\hline mar-06 & 279 & 199 & $29 \%$ & 32 & $89 \%$ & 25,20 & 23,6 & $6 \%$ & 2,9 & $88 \%$ & 16,50 & 1,80 & $89 \%$ & 3,70 & 3,1 & $16 \%$ \\
\hline abr-06 & 332 & 252 & $24 \%$ & 36 & $89 \%$ & 29,30 & 29,1 & $1 \%$ & 3,8 & $87 \%$ & 20,80 & 1,36 & $93 \%$ & 4,40 & 4,5 & $0 \%$ \\
\hline mai-06 & 460 & 288 & $37 \%$ & 38 & $92 \%$ & 36,50 & 33,1 & $9 \%$ & 4,8 & $87 \%$ & 22,80 & 4,00 & $82 \%$ & 4,90 & 4,6 & $6 \%$ \\
\hline jun-06 & 514 & 270 & $47 \%$ & 36 & $93 \%$ & 41,80 & 37,6 & $10 \%$ & 3,71 & $91 \%$ & 28,50 & 2,25 & $92 \%$ & 5,00 & 5,8 & $0 \%$ \\
\hline jul-06 & 456 & 282 & $38 \%$ & 42 & $91 \%$ & 33,00 & 32,4 & $2 \%$ & 3,23 & $90 \%$ & 23,30 & 1,80 & $92 \%$ & 4,60 & 4,2 & $9 \%$ \\
\hline ago-06 & 388 & 326 & $16 \%$ & 42 & $89 \%$ & 43,00 & 39,1 & $9 \%$ & 10,1 & $77 \%$ & 32,00 & 8,82 & $72 \%$ & 5,30 & 4,6 & $13 \%$ \\
\hline set-06 & 416 & 271 & $35 \%$ & 30 & $93 \%$ & 38,90 & 38,0 & $2 \%$ & 5,7 & $85 \%$ & 26,70 & 4,70 & $82 \%$ & 4,80 & 3,3 & $31 \%$ \\
\hline out-06 & 558 & 385 & $31 \%$ & 41 & $93 \%$ & 39,70 & 41,0 & $0 \%$ & 9,21 & $77 \%$ & 25,30 & 8,40 & $67 \%$ & 8,80 & 4,5 & $49 \%$ \\
\hline nov-06 & 399 & 329 & $18 \%$ & 38 & $90 \%$ & & & & & & & & & & & \\
\hline dez-06 & 322 & 230 & $29 \%$ & 34 & $89 \%$ & 30,80 & 27,2 & $12 \%$ & 7 & $77 \%$ & 22,00 & 5,60 & $75 \%$ & & & \\
\hline jan-07 & 335 & 259 & $23 \%$ & 31 & $91 \%$ & 32,04 & 30,5 & $5 \%$ & 4,00 & $88 \%$ & 19,60 & 3,44 & $82 \%$ & 7,25 & 5,6 & $23 \%$ \\
\hline fev-07 & 362 & 266 & $27 \%$ & 24 & $93 \%$ & 46,40 & 25,4 & $45 \%$ & 1,85 & $96 \%$ & 25,13 & 0,63 & $97 \%$ & 14,00 & 1,5 & $89 \%$ \\
\hline mar-07 & 314 & 187 & $40 \%$ & 30 & $91 \%$ & 32,10 & 27,0 & $16 \%$ & 2,26 & $93 \%$ & 20,10 & 2,03 & $90 \%$ & 3,03 & 3,6 & $0 \%$ \\
\hline abr-07 & 431 & 216 & $50 \%$ & 37 & $91 \%$ & 32,90 & 27,0 & $18 \%$ & 6,00 & $82 \%$ & 20,80 & 4,40 & $79 \%$ & 6,90 & 4,5 & $35 \%$ \\
\hline mai-07 & 530 & 239 & $55 \%$ & 32 & $94 \%$ & 38,10 & 29,0 & $24 \%$ & 3,60 & $91 \%$ & 23,40 & 2,94 & $87 \%$ & 4,50 & 1,3 & $71 \%$ \\
\hline jun-07 & 604 & 324 & $46 \%$ & 34 & $94 \%$ & 34,30 & 34,2 & $0 \%$ & 10,50 & $69 \%$ & 21,40 & 8,80 & $59 \%$ & 6,80 & 3,9 & $43 \%$ \\
\hline jul-07 & & & & & & 40,00 & 31,6 & $21 \%$ & 10,60 & $74 \%$ & 22,00 & 9,10 & $59 \%$ & 7,00 & 2,6 & $63 \%$ \\
\hline ago-07 & 678 & 452 & $33 \%$ & 43 & $94 \%$ & & & & & & 26,70 & 8,39 & $69 \%$ & 17,80 & 8,6 & $52 \%$ \\
\hline set-07 & 627 & 503 & $20 \%$ & 46 & $93 \%$ & 43,00 & 39,7 & $8 \%$ & 9,36 & $78 \%$ & 27,00 & 2,82 & $90 \%$ & 11,00 & 9,8 & $11 \%$ \\
\hline out-07 & 689 & 536 & $22 \%$ & 39 & $94 \%$ & & & & & & 27,80 & 2,07 & $93 \%$ & 15,60 & 9,4 & $40 \%$ \\
\hline nov-07 & & & & & & & & & & & 19,20 & 0,81 & $96 \%$ & 6,00 & 2,0 & $67 \%$ \\
\hline dez-07 & 555 & 341 & $39 \%$ & 38 & $93 \%$ & 42,00 & 39,6 & $6 \%$ & 2,67 & $94 \%$ & 23,00 & 2,95 & $87 \%$ & 6,70 & 5,2 & $23 \%$ \\
\hline jan-08 & 400 & 275 & $31 \%$ & 31 & $92 \%$ & 30,90 & 27,0 & $13 \%$ & 3,86 & $88 \%$ & 18,80 & 2,42 & $87 \%$ & 3,50 & 2,3 & $36 \%$ \\
\hline fev-08 & 359 & 293 & $18 \%$ & 31 & $91 \%$ & 32,80 & 24,3 & $26 \%$ & 4,05 & $88 \%$ & 17,80 & 4,21 & $76 \%$ & 4,80 & 2,0 & $58 \%$ \\
\hline mar-08 & 487 & 331 & $32 \%$ & 37 & $92 \%$ & & & & & & 22,13 & 7,79 & $65 \%$ & 11,20 & 4,2 & $63 \%$ \\
\hline
\end{tabular}


Tabela 19 - Dados Mensais da Fase Líquida (conclusão).

\begin{tabular}{|c|c|c|c|c|c|c|c|c|}
\hline DATA & $\begin{array}{c}\text { P efluente } \\
\text { final } \\
\text { (mg/L) }\end{array}$ & $\begin{array}{c}\text { eficiência de } \\
\text { remoção } \\
\text { total na ETE } \\
\text { - P (\%) }\end{array}$ & $\begin{array}{c}\mathrm{Fe} \\
\text { afluente } \\
\text { (mg/L) }\end{array}$ & $\begin{array}{c}\mathrm{Fe} \\
\text { efluente } \\
\text { primário } \\
\text { (mg/L) }\end{array}$ & $\begin{array}{l}\text { eficiência de } \\
\text { remoção Fe } \\
\text { - decantador } \\
\text { primário (\%) }\end{array}$ & $\begin{array}{l}\text { Fe efluente } \\
\text { final (mg/L) }\end{array}$ & $\begin{array}{c}\text { eficiência de } \\
\text { remoção } \\
\text { total na ETE } \\
\text { - Fe (\%) }\end{array}$ & $\underset{(\mathrm{mL} / \mathrm{g})}{\mathrm{IVL}}$ \\
\hline jan-05 & & & 6,74 & 5,412 & $20 \%$ & 0,79 & $88 \%$ & 46 \\
\hline fev-05 & 2,55 & $49 \%$ & 6,97 & 4,81 & $31 \%$ & 0,64 & $91 \%$ & 45 \\
\hline mar-05 & 3,20 & $60 \%$ & 10,91 & 3,92 & $64 \%$ & 0,31 & $97 \%$ & 50 \\
\hline abr-05 & 2,55 & $42 \%$ & 4,28 & 3,78 & $12 \%$ & 0,74 & $83 \%$ & 47 \\
\hline mai-05 & 1,75 & $71 \%$ & 5,98 & 4,75 & $21 \%$ & 0,31 & $95 \%$ & 49 \\
\hline jun-05 & 3,30 & $54 \%$ & 7,02 & 3,05 & $57 \%$ & 0,25 & $96 \%$ & 51 \\
\hline jul-05 & 3,20 & $45 \%$ & 4,36 & 3,78 & $13 \%$ & 0,54 & $88 \%$ & 53 \\
\hline ago-05 & 4,10 & $32 \%$ & 25,26 & 17,84 & $29 \%$ & 0,44 & $98 \%$ & 63 \\
\hline set-05 & & & 12,99 & 12,60 & $3 \%$ & 0,38 & $97 \%$ & 78 \\
\hline out-05 & 2,70 & $68 \%$ & 13,19 & 6,57 & $50 \%$ & 0,47 & $96 \%$ & 69 \\
\hline nov-05 & & & 10,02 & 7,55 & $25 \%$ & 0,41 & $96 \%$ & 61 \\
\hline dez-05 & 2,30 & $56 \%$ & 6,14 & 3,54 & $42 \%$ & 0,59 & $90 \%$ & 71 \\
\hline jan-06 & 2,70 & $64 \%$ & 13,55 & 6,21 & $54 \%$ & 1,03 & $92 \%$ & 58 \\
\hline fev-06 & 1,90 & $53 \%$ & 7,10 & 4,36 & $39 \%$ & 0,25 & $97 \%$ & 54 \\
\hline mar-06 & 1,95 & $47 \%$ & 14,83 & 12,23 & $18 \%$ & 0,42 & $97 \%$ & 61 \\
\hline abr-06 & 2,20 & $50 \%$ & 3,00 & 3,60 & $0 \%$ & 0,59 & $80 \%$ & 62 \\
\hline mai-06 & 2,95 & $40 \%$ & 4,78 & 2,75 & $42 \%$ & 0,38 & $92 \%$ & 69 \\
\hline jun-06 & 2,80 & $44 \%$ & 4,85 & 3,54 & $27 \%$ & 0,34 & $93 \%$ & 59 \\
\hline jul-06 & 2,60 & $43 \%$ & 4,28 & 2,22 & $48 \%$ & 0,58 & $87 \%$ & 75 \\
\hline ago-06 & 3,10 & $42 \%$ & 2,77 & 2,09 & $24 \%$ & 0,71 & $75 \%$ & 85 \\
\hline set-06 & 1,80 & $63 \%$ & 3,48 & 1,51 & $57 \%$ & 0,15 & $96 \%$ & 105 \\
\hline out-06 & 3,20 & $64 \%$ & 9,39 & 4,26 & $55 \%$ & 0,64 & $93 \%$ & 119 \\
\hline nov-06 & & & & & & & & 138 \\
\hline dez-06 & & & & & & & & 72 \\
\hline jan-07 & 1,67 & $77 \%$ & & & & & & 68 \\
\hline fev-07 & 0,36 & $97 \%$ & 76,49 & 26,41 & $65 \%$ & 0,36 & $100 \%$ & 55 \\
\hline mar-07 & 1,75 & $42 \%$ & & & & & & 55 \\
\hline abr-07 & 2,25 & $67 \%$ & 5,38 & 5,59 & $0 \%$ & 1,00 & $81 \%$ & 78 \\
\hline mai-07 & 0,40 & $91 \%$ & 63,69 & 3,85 & $94 \%$ & 0,78 & $99 \%$ & 122 \\
\hline jun-07 & 0,24 & $96 \%$ & 45,91 & 26,92 & $41 \%$ & 0,39 & $99 \%$ & 147 \\
\hline jul-07 & 0,30 & $96 \%$ & & & & & & \\
\hline ago-07 & 1,30 & $93 \%$ & 37,81 & 13,26 & $65 \%$ & 0,43 & $99 \%$ & 178 \\
\hline set-07 & 0,16 & $99 \%$ & 30,93 & 21,92 & $29 \%$ & 0,41 & $99 \%$ & 163 \\
\hline out-07 & 0,27 & $98 \%$ & 74,61 & 36,72 & $51 \%$ & 0,96 & $99 \%$ & 135 \\
\hline nov-07 & 0,20 & $97 \%$ & 30,46 & 9,71 & $68 \%$ & 0,40 & $99 \%$ & 113 \\
\hline dez-07 & 0,28 & $96 \%$ & & & & & & 135 \\
\hline jan-08 & 0,36 & $90 \%$ & 16,12 & 11,49 & $29 \%$ & 1,78 & $89 \%$ & 109 \\
\hline fev-08 & 0,55 & $89 \%$ & 31,05 & 10,11 & $67 \%$ & 2,14 & $93 \%$ & 127 \\
\hline mar-08 & 0,32 & $97 \%$ & & & & & & 159 \\
\hline
\end{tabular}


ANEXO B - DADOS UTILIZADOS - FASE SÓLIDA 
Tabela 20 - Dados da Fase Sólida.

\begin{tabular}{|c|c|c|c|c|c|c|c|c|c|c|c|c|c|c|c|c|c|c|}
\hline DATA & $\begin{array}{l}\text { Vazão de } \\
\text { Lodo } \\
\text { Primário } \\
\text { (L/s) }\end{array}$ & $\begin{array}{l}\text { SST - } \\
\text { Lodo } \\
\text { Primário } \\
(\%)\end{array}$ & $\begin{array}{c}\text { SSV - } \\
\text { Lodo } \\
\text { Primário } \\
(\%)\end{array}$ & $\begin{array}{l}\text { Vazão de } \\
\text { Lodo } \\
\text { Adensado } \\
\text { (L/s) }\end{array}$ & $\begin{array}{c}\text { SST - } \\
\text { Lodo } \\
\text { Adensado } \\
(\%)\end{array}$ & $\begin{array}{c}\text { SSV - } \\
\text { Lodo } \\
\text { Adensado } \\
(\%)\end{array}$ & $\begin{array}{c}\text { Vazão de } \\
\text { Lodo } \\
\text { Recirculado } \\
\text { (L/s) }\end{array}$ & $\begin{array}{l}\text { Vazão de } \\
\text { Lodo } \\
\text { Descartado } \\
\text { (L/s) }\end{array}$ & $\begin{array}{c}\text { SST - Lodo } \\
\text { Secundário } \\
\text { (\%) }\end{array}$ & $\begin{array}{c}\text { SSV - Lodo } \\
\text { Secundário } \\
\text { (\%) }\end{array}$ & $\begin{array}{l}\text { Vazão de } \\
\text { Lodo } \\
\text { Flotado } \\
\text { (L/s) }\end{array}$ & $\begin{array}{l}\text { SST - } \\
\text { Lodo } \\
\text { Flotado } \\
(\%)\end{array}$ & $\begin{array}{l}\text { SSV - } \\
\text { Lodo } \\
\text { Flotado } \\
(\%)\end{array}$ & $\begin{array}{l}\text { Vazão de } \\
\text { Lodo } \\
\text { Digerido } \\
\text { (L/s) }\end{array}$ & $\begin{array}{c}\text { ST - } \\
\text { Lodo } \\
\text { Digerido } \\
(\%)\end{array}$ & $\begin{array}{c}\text { SV - } \\
\text { Lodo } \\
\text { Digerido } \\
(\%)\end{array}$ & $\begin{array}{l}\text { Produção } \\
\text { final de } \\
\text { lodo }(t / d)\end{array}$ & $\begin{array}{c}\text { Teor de } \\
\text { sólidos - } \\
\text { Lodo } \\
\text { desidratado } \\
\text { final (\%) }\end{array}$ \\
\hline jan-05 & 3,01 & & $2,0 \%$ & 2,70 & $3,6 \%$ & $1,6 \%$ & 1.102 & 21,0 & $0,6 \%$ & $0,4 \%$ & 1,60 & $1,9 \%$ & $1,1 \%$ & 2,4 & $3,1 \%$ & $1,4 \%$ & 37 & 35 \\
\hline fev-05 & 2,77 & $3,3 \%$ & $1,7 \%$ & 3,50 & $3,3 \%$ & $1,6 \%$ & 1.021 & 23,3 & $0,6 \%$ & $0,4 \%$ & 0,50 & & & 1,8 & $4,2 \%$ & $1,7 \%$ & 46 & 36 \\
\hline mar-05 & 3,56 & $3,0 \%$ & $1,6 \%$ & 2,50 & $3,8 \%$ & $1,9 \%$ & 1.052 & 22,3 & $0,7 \%$ & $0,4 \%$ & 0,90 & $2,1 \%$ & $1,4 \%$ & 2,0 & $4,5 \%$ & $1,9 \%$ & 35 & 39 \\
\hline abr-05 & 3,50 & $3,3 \%$ & $1,6 \%$ & 4,11 & $2,8 \%$ & $1,4 \%$ & 1.054 & 24,1 & $0,6 \%$ & $0,3 \%$ & 0,90 & $2,8 \%$ & $1,7 \%$ & 4,3 & $3,9 \%$ & $1,7 \%$ & 64 & 39 \\
\hline mai-05 & 5,10 & $2,8 \%$ & $1,8 \%$ & 5,00 & $2,6 \%$ & $1,4 \%$ & 1.075 & 27,0 & $0,4 \%$ & $0,3 \%$ & 0,89 & $2,3 \%$ & $1,6 \%$ & 4,2 & $3,2 \%$ & $1,6 \%$ & 56 & 40 \\
\hline jun-05 & 5,00 & $2,9 \%$ & $1,8 \%$ & 2,64 & $2,4 \%$ & $1,5 \%$ & 1.143 & 24,8 & $0,4 \%$ & $0,3 \%$ & 0,85 & $1,8 \%$ & $1,2 \%$ & 3,3 & $3,5 \%$ & $1,7 \%$ & 42 & 37 \\
\hline jul-05 & 6,89 & $2,8 \%$ & $1,9 \%$ & 5,20 & $2,9 \%$ & $1,9 \%$ & 1.084 & 22,1 & $0,6 \%$ & $0,4 \%$ & 0,50 & $2,0 \%$ & $1,5 \%$ & 1,9 & & & 31 & 34 \\
\hline ago-05 & 6,60 & $3,0 \%$ & $2,0 \%$ & 5,20 & $2,7 \%$ & $1,7 \%$ & 1.023 & 22,0 & $0,7 \%$ & $0,5 \%$ & 0,00 & & & 3,3 & $4,2 \%$ & $1,9 \%$ & 52 & 36 \\
\hline set-05 & 7,60 & $2,5 \%$ & $1,6 \%$ & 5,94 & $3,0 \%$ & $1,7 \%$ & 1.057 & 25,4 & $1,1 \%$ & $0,8 \%$ & 0,30 & & & 2,6 & $3,5 \%$ & $1,7 \%$ & 39 & 37 \\
\hline out-05 & 6,20 & $2,4 \%$ & $1,5 \%$ & 5,80 & $2,9 \%$ & $1,7 \%$ & 1.149 & 26,3 & $1,1 \%$ & $0,8 \%$ & 1,30 & $2,4 \%$ & $1,7 \%$ & 3,6 & $3,7 \%$ & $1,9 \%$ & 57 & 37 \\
\hline nov-05 & 8,49 & $2,4 \%$ & $1,5 \%$ & 4,23 & $2,8 \%$ & $1,6 \%$ & 1.186 & 25,8 & $0,9 \%$ & $0,6 \%$ & 1,30 & $2,5 \%$ & $1,7 \%$ & 2,7 & $3,8 \%$ & $2,0 \%$ & 39 & 37 \\
\hline dez-05 & 13,50 & $2,3 \%$ & $1,3 \%$ & 1,16 & $3,1 \%$ & $1,8 \%$ & 1.146 & 23,1 & & & 0,69 & $2,2 \%$ & $1,4 \%$ & 1,8 & $4,0 \%$ & $1,9 \%$ & 22 & 33 \\
\hline jan-06 & 7,67 & $2,2 \%$ & $1,2 \%$ & 2,11 & $3,1 \%$ & $1,6 \%$ & 1.149 & 22,9 & $1,0 \%$ & $0,6 \%$ & 2,11 & $2,1 \%$ & $1,3 \%$ & 3,4 & $3,7 \%$ & $1,9 \%$ & 62 & 36 \\
\hline fev-06 & 10,61 & $2,7 \%$ & $1,3 \%$ & 2,23 & $3,0 \%$ & $1,3 \%$ & 1.236 & 21,7 & $0,7 \%$ & $0,4 \%$ & 3,48 & $1,7 \%$ & $1,0 \%$ & 3,7 & $4,0 \%$ & $2,1 \%$ & 67 & 39 \\
\hline mar-06 & 7,59 & $3,0 \%$ & $1,6 \%$ & 1,53 & $4,8 \%$ & $2,1 \%$ & 1.225 & 19,0 & $0,7 \%$ & $0,4 \%$ & 3,19 & $2,2 \%$ & $1,4 \%$ & 2,8 & $3,9 \%$ & $2,0 \%$ & 58 & 37 \\
\hline abr-06 & 5,32 & $3,6 \%$ & $1,8 \%$ & 0,99 & $5,7 \%$ & $2,1 \%$ & 1.242 & 16,0 & $0,7 \%$ & $0,5 \%$ & 3,07 & $2,8 \%$ & $1,9 \%$ & 2,7 & $3,8 \%$ & $1,9 \%$ & 53 & 37 \\
\hline mai-06 & 12,85 & $2,3 \%$ & $1,4 \%$ & 1,70 & $6,0 \%$ & $2,5 \%$ & 1.187 & 19,0 & $0,6 \%$ & $0,4 \%$ & 3,20 & $2,8 \%$ & $2,0 \%$ & 2,7 & $3,8 \%$ & $1,9 \%$ & 55 & 35 \\
\hline jun-06 & 6,71 & $3,1 \%$ & $1,9 \%$ & 2,70 & $3,9 \%$ & $2,0 \%$ & 1.067 & 18,0 & $0,6 \%$ & $0,4 \%$ & 3,79 & $2,2 \%$ & $1,6 \%$ & 4,3 & $3,9 \%$ & $2,1 \%$ & 71 & 37 \\
\hline jul-06 & 5,69 & $2,8 \%$ & $1,7 \%$ & 2,46 & $4,8 \%$ & $2,4 \%$ & 1.282 & 20,0 & $0,6 \%$ & $0,5 \%$ & 3,82 & $2,5 \%$ & $1,9 \%$ & 4,4 & $3,6 \%$ & $2,0 \%$ & 63 & 31 \\
\hline ago-06 & 5,99 & $2,5 \%$ & $1,7 \%$ & 2,76 & $2,8 \%$ & $1,5 \%$ & 1.282 & 25,0 & $0,5 \%$ & $0,4 \%$ & 4,30 & $2,5 \%$ & $2,0 \%$ & 4,6 & $3,6 \%$ & $2,0 \%$ & 67 & 30 \\
\hline set-06 & 8,88 & $2,9 \%$ & $1,6 \%$ & 1,63 & $3,4 \%$ & $1,9 \%$ & 1.219 & 26,0 & $0,6 \%$ & $0,5 \%$ & 4,37 & $2,4 \%$ & $1,7 \%$ & 4,6 & $3,4 \%$ & $1,9 \%$ & 63 & 34 \\
\hline out-06 & 12,31 & $2,3 \%$ & $1,5 \%$ & 3,01 & $3,1 \%$ & $1,7 \%$ & 1.169 & 24,0 & $0,8 \%$ & $0,6 \%$ & 1,95 & $2,1 \%$ & $1,4 \%$ & 2,4 & $3,6 \%$ & $2,0 \%$ & 36 & 36 \\
\hline nov-06 & 10,09 & $2,5 \%$ & $1,4 \%$ & 4,01 & $2,6 \%$ & $1,3 \%$ & 1.177 & 21,0 & $1,0 \%$ & $0,7 \%$ & 2,18 & $2,6 \%$ & $1,6 \%$ & 4,0 & $3,3 \%$ & $1,9 \%$ & 54 & 33 \\
\hline dez-06 & 5,96 & $4,4 \%$ & $1,9 \%$ & 4,48 & $3,7 \%$ & $1,6 \%$ & 1.195 & 21,0 & $0,7 \%$ & $0,4 \%$ & 3,66 & & & 4,0 & $4,2 \%$ & $2,2 \%$ & 60 & 35 \\
\hline jan-07 & 7,30 & $3,5 \%$ & $1,6 \%$ & 2,78 & $4,3 \%$ & $1,6 \%$ & 1.182 & 22,0 & $0,8 \%$ & $0,5 \%$ & 2,76 & $3,1 \%$ & $1,9 \%$ & 4,2 & $4,3 \%$ & $2,0 \%$ & 69 & 41 \\
\hline fev-07 & 8,64 & $3,4 \%$ & $1,4 \%$ & 3,95 & $5,1 \%$ & $1,8 \%$ & 1.197 & 24,0 & $0,8 \%$ & $0,4 \%$ & 2,20 & $3,1 \%$ & $1,8 \%$ & 6,5 & $4,1 \%$ & $1,8 \%$ & 96 & 42 \\
\hline mar-07 & 9,07 & $4,2 \%$ & $1,8 \%$ & 5,60 & $3,9 \%$ & $1,7 \%$ & 1.137 & & $0,5 \%$ & $0,3 \%$ & 0,65 & $3,1 \%$ & $1,8 \%$ & 5,8 & $4,5 \%$ & $1,8 \%$ & 90 & 42 \\
\hline abr-07 & 14,89 & $2,7 \%$ & $1,5 \%$ & 7,51 & $2,2 \%$ & $1,1 \%$ & 1.174 & 21,0 & $0,4 \%$ & $0,3 \%$ & 0,72 & $2,7 \%$ & $1,9 \%$ & 4,4 & $4,4 \%$ & $1,9 \%$ & 61 & 41 \\
\hline mai-07 & 13,61 & $3,2 \%$ & $1,7 \%$ & 7,07 & $3,9 \%$ & $1,9 \%$ & 1.393 & 23,7 & $0,4 \%$ & $0,3 \%$ & 0,86 & $3,1 \%$ & $2,2 \%$ & 5,3 & $3,7 \%$ & $1,8 \%$ & 69 & 35 \\
\hline jun-07 & 16,50 & $2,8 \%$ & $1,4 \%$ & 6,76 & $3,8 \%$ & $1,7 \%$ & 1.398 & 27,0 & $0,6 \%$ & $0,4 \%$ & 0,75 & $2,2 \%$ & $1,4 \%$ & 6,1 & $3,6 \%$ & $1,8 \%$ & 79 & 38 \\
\hline jul-07 & 15,10 & $2,7 \%$ & $1,5 \%$ & 6,07 & $4,1 \%$ & $2,0 \%$ & 1.436 & 29,1 & $0,7 \%$ & $0,5 \%$ & 0,54 & $2,4 \%$ & $1,6 \%$ & 4,5 & $4,0 \%$ & $1,9 \%$ & 59 & 37 \\
\hline ago-07 & 11,90 & $2,7 \%$ & $1,6 \%$ & 8,52 & $3,0 \%$ & $1,5 \%$ & 1.324 & 29,0 & $0,7 \%$ & $0,5 \%$ & 1,45 & $2,2 \%$ & $1,6 \%$ & 5,5 & $3,3 \%$ & $1,7 \%$ & 72 & 33 \\
\hline set-07 & 10,05 & $2,0 \%$ & $1,2 \%$ & 6,23 & $3,2 \%$ & $1,8 \%$ & 1.453 & 26,0 & $0,9 \%$ & $0,6 \%$ & 0,73 & $2,4 \%$ & $1,7 \%$ & 5,4 & $2,9 \%$ & $1,6 \%$ & 77 & 32 \\
\hline out-07 & 3,34 & $2,5 \%$ & $1,4 \%$ & 10,25 & $2,5 \%$ & $1,4 \%$ & 1.300 & 29,0 & $1,1 \%$ & $0,7 \%$ & 0,96 & $2,5 \%$ & $1,7 \%$ & & $2,6 \%$ & $1,4 \%$ & & 33 \\
\hline nov-07 & 10,81 & $2,6 \%$ & $1,4 \%$ & 7,60 & $3,4 \%$ & $1,7 \%$ & 1.285 & 29,0 & $1,0 \%$ & $0,6 \%$ & 0,70 & $3,0 \%$ & $1,7 \%$ & 6,3 & $3,1 \%$ & $1,6 \%$ & 92 & 31 \\
\hline dez-07 & 10,82 & $2,7 \%$ & $1,5 \%$ & 9,39 & $2,7 \%$ & $1,5 \%$ & 1.344 & 26,0 & $0,9 \%$ & $0,6 \%$ & 0,64 & $2,4 \%$ & $1,5 \%$ & 6,4 & $3,0 \%$ & $1,5 \%$ & 87 & 31,5 \\
\hline jan-08 & 10,28 & $1,8 \%$ & $1,0 \%$ & 10,02 & $1,9 \%$ & $1,0 \%$ & 1.342 & 24,6 & $0,8 \%$ & $0,5 \%$ & 0,59 & $1,6 \%$ & $0,9 \%$ & 6,7 & $3,1 \%$ & $1,6 \%$ & 89 & 33 \\
\hline fev-08 & 9,39 & $2,3 \%$ & $1,3 \%$ & 6,00 & $2,8 \%$ & $1,3 \%$ & 1.326 & 22,0 & $0,7 \%$ & $0,5 \%$ & 0,50 & $1,4 \%$ & $0,9 \%$ & 1,7 & $3,5 \%$ & $1,7 \%$ & & 36,3 \\
\hline mar-08 & 16,31 & $2,1 \%$ & $1,2 \%$ & 9,63 & $2,5 \%$ & $1,1 \%$ & 1.412 & 23,0 & $1,1 \%$ & $0,6 \%$ & 0,58 & $1,7 \%$ & $1,0 \%$ & 6,3 & $3,7 \%$ & $1,7 \%$ & 88 & 35,23 \\
\hline
\end{tabular}


ANEXO C - DADOS UTILIZADOS - PARÂMETROS OPERACIONAIS 
Tabela 21 - Parâmetros Operacionais.

\begin{tabular}{|c|c|c|c|c|c|c|c|c|c|c|c|c|c|}
\hline Data & $\begin{array}{c}\text { TAS - } \\
\text { decantador } \\
\text { primário } \\
\left(\mathrm{m}^{3} / \mathrm{m}^{2} . \text { dia }\right)\end{array}$ & $\begin{array}{c}\text { TAS - } \\
\text { adensador } \\
\text { por gravidade } \\
\left(\mathrm{m}^{3} / \mathrm{m}^{2} . \text { dia }\right)\end{array}$ & $\begin{array}{c}\text { TASol - } \\
\text { adensador } \\
\text { por gravidade } \\
\left(\mathrm{kg} / \mathrm{m}^{2} . \text { dia) }\right.\end{array}$ & $\begin{array}{l}\text { Tanques de } \\
\text { aeração - } \\
\text { Idade do Lodo } \\
\text { (dias) }\end{array}$ & $\begin{array}{c}\text { Tanques de } \\
\text { aeração - } \\
\text { Relação A/M } \\
\text { (kgDBO I } \\
\text { kgSSV.dia) }\end{array}$ & $\begin{array}{c}\text { TAS - } \\
\text { decantador } \\
\text { secundário } \\
\left(\mathrm{m}^{3} / \mathrm{m}^{2} \text {.dia) }\right.\end{array}$ & $\begin{array}{l}\text { TASol - } \\
\text { decantador } \\
\text { secundário } \\
\left(\mathrm{kg} / \mathrm{m}^{2} . \mathrm{dia}\right)\end{array}$ & $\begin{array}{l}\text { TASol - } \\
\text { flotadores } \\
\text { (kg/m².dia) }\end{array}$ & $\begin{array}{l}\text { Tempo de } \\
\text { detenção - } \\
\text { Digestores } \\
\text { (dias) }\end{array}$ & $\begin{array}{l}\text { Produção } \\
\text { de gás - } \\
\text { Digestores } \\
\left(\mathrm{m}^{3} / \mathrm{dia}\right)\end{array}$ & $\begin{array}{l}\text { Remoção de } \\
\text { SV - } \\
\text { Digestores } \\
(\%)\end{array}$ & $\begin{array}{l}\text { Consumo de CaO - } \\
\text { Condicionamento } \\
\text { (kg/dia) }\end{array}$ & $\begin{array}{c}\text { Consumo de } \mathrm{FeCl}_{3}- \\
\text { Condicionamento } \\
\text { (kg/dia) }\end{array}$ \\
\hline jan-05 & 39,9 & 0,39 & 17,99 & 4 & 0,28 & 16 & 2,03 & 73,47 & 57 & & 32 & 1.710 & 1.560 \\
\hline fev-05 & 38,8 & 0,36 & 11,95 & 4 & 0,41 & 16 & 1,98 & 79,40 & 61 & 1.591 & 21 & 1.428 & 1.607 \\
\hline mar-05 & 38,1 & 0,47 & 14,09 & 4 & 0,21 & 15 & 2,50 & 88,90 & 72 & & 6 & 2.256 & 1.253 \\
\hline abr-05 & 40,6 & 0,46 & 14,92 & 4 & 0,41 & 16 & 2,26 & 75,85 & 49 & & 20 & 3.117 & 3.179 \\
\hline mai-05 & 39,8 & 0,67 & 18,83 & 4 & 0,43 & 16 & 1,71 & 57,02 & 41 & 2.123 & 18 & 3.273 & 2.620 \\
\hline jun-05 & 42,6 & 0,65 & 19,05 & 4 & 0,36 & 17 & 1,79 & 58,30 & 70 & 1.759 & 7 & 2.606 & 1.948 \\
\hline jul-05 & 41,9 & 0,90 & 25,34 & 4 & 0,37 & 17 & 2,21 & 70,40 & 43 & 2.518 & -16 & 1.592 & 1.239 \\
\hline ago-05 & 24,4 & 0,86 & 26,01 & 4 & 0,54 & 15 & 2,25 & 84,05 & 47 & 1.673 & 5 & 3.307 & 2.027 \\
\hline set-05 & 26,3 & 0,99 & 24,83 & 4 & 0,42 & 16 & 3,55 & 161,57 & 39 & 1.156 & 17 & 1.657 & 1.126 \\
\hline out-05 & 28,7 & 0,81 & 19,87 & 4 & 0,27 & 17 & 4,11 & 167,08 & 34 & 1.170 & -4 & 1.458 & 2.247 \\
\hline nov-05 & 28,5 & 1,11 & 26,81 & 4 & 0,30 & 17 & 3,50 & 134,46 & 44 & 1.240 & 0 & 2.142 & 1.610 \\
\hline dez-05 & 29,5 & 1,77 & 40,44 & 4 & 0,25 & 18 & 4,73 & 179,43 & 132 & 645 & 2 & 1.098 & 868 \\
\hline jan-06 & 27,7 & 0,50 & 10,97 & 4 & 0,23 & 17 & 3,27 & 124,97 & 58 & 1.235 & 19 & 2.858 & 2.235 \\
\hline fev-06 & 44,6 & 0,69 & 18,92 & 5 & 0,29 & 18 & 2,70 & 82,09 & 43 & 1.480 & 10 & 2.929 & 2.132 \\
\hline mar-06 & 44,8 & 0,50 & 14,71 & 5 & 0,26 & 18 & 2,39 & 70,79 & 52 & 1.428 & 19 & 2.539 & 2.081 \\
\hline abr-06 & 46,3 & 0,35 & 12,61 & 5 & 0,31 & 19 & 2,56 & 64,68 & 60 & 1.145 & 25 & 2.485 & 1.912 \\
\hline mai-06 & 43,4 & 0,84 & 19,17 & 5 & 0,33 & 24 & 2,91 & 59,99 & 50 & 1.905 & 21 & 2.589 & 1.993 \\
\hline jun-06 & 40,3 & 0,44 & 13,70 & 5 & 0,33 & 16 & 2,00 & 57,85 & 38 & 2.367 & 9 & 3.886 & 2.986 \\
\hline jul-06 & 45,6 & 0,37 & 10,35 & 5 & 0,36 & 19 & 2,31 & 67,35 & 39 & 2.275 & 17 & 3.725 & 2.846 \\
\hline ago-06 & 45,5 & 0,39 & 9,61 & 4 & 0,41 & 18 & 2,18 & 75,84 & 34 & 3.273 & 13 & 4.004 & 3.203 \\
\hline set-06 & 45,5 & 0,58 & 17,02 & 4 & 0,30 & 18 & 2,35 & 89,49 & 41 & 3.239 & 20 & 3.789 & 3.139 \\
\hline out-06 & 29,9 & 0,81 & 18,89 & 4 & 0,37 & 18 & 3,14 & 110,38 & 49 & 1.838 & 13 & 1.950 & 1.584 \\
\hline nov-06 & 31,5 & 0,66 & 16,33 & 4 & 0,22 & 19 & 3,76 & 117,81 & 39 & 1.110 & 9 & 3.464 & 2.751 \\
\hline dez-06 & 30,8 & 0,39 & 17,00 & 4 & 0,31 & 25 & 3,37 & 84,00 & 30 & 2.137 & 13 & 3.910 & 2.644 \\
\hline jan-07 & 48,0 & 0,96 & 33,28 & 4 & 0,44 & 26 & 3,92 & 95,84 & 44 & 2.037 & 14 & 3.500 & 2.990 \\
\hline fev-07 & 33,2 & 1,13 & 38,11 & 4 & 0,50 & 27 & 4,33 & 101,77 & 40 & 1.823 & 14 & 5.947 & 4.273 \\
\hline mar-07 & 33,6 & 1,19 & 49,80 & 5 & 0,35 & 27 & 3,13 & 89,24 & 39 & 2.996 & 15 & 5.651 & 3.279 \\
\hline abr-07 & 33,3 & 1,95 & 52,25 & 5 & 0,45 & 27 & 2,52 & 49,12 & 30 & 3.806 & 5 & 7.198 & 2.298 \\
\hline mai-07 & 32,0 & 1,78 & 57,40 & 5 & 0,39 & 20 & 2,13 & 60,03 & 31 & 5.457 & 17 & 4.502 & 2.826 \\
\hline jun-07 & 32,3 & 2,16 & 60,10 & 4 & 0,54 & 20 & 2,90 & 85,38 & 32 & 4.519 & 25 & 4.409 & 2.673 \\
\hline jul-07 & 36,7 & 0,99 & 26,80 & 4 & 0,51 & 22 & 3,58 & 117,82 & 37 & 4.037 & 27 & 3.747 & 2.391 \\
\hline ago-07 & 31,1 & 0,78 & 21,13 & 4 & 0,84 & 15 & 2,52 & 109,30 & 24 & 3.656 & 11 & 6.779 & 2.649 \\
\hline set-07 & 23,6 & 0,66 & 12,98 & 4 & 0,47 & 15 & 3,36 & 138,34 & 35 & 2.479 & 28 & 5.732 & 2.378 \\
\hline out-07 & 26,4 & 0,22 & 5,36 & 4 & 0,83 & 17 & 4,89 & 184,81 & 22 & 1.726 & 15 & 6.033 & 3.906 \\
\hline nov-07 & 31,0 & 1,42 & 36,61 & 4 & 0,53 & 17 & 4,27 & 165,70 & 29 & 2.028 & 12 & 5.261 & 3.231 \\
\hline dez-07 & 36,1 & 1,42 & 38,39 & 4 & 0,38 & 18 & 3,93 & 137,81 & 24 & 2.122 & 16 & 8.019 & 3.161 \\
\hline jan-08 & 32,9 & 1,35 & 24,12 & 4 & 0,59 & 21 & 3,37 & 106,01 & 23 & 3.536 & 17 & 6.774 & 3.822 \\
\hline fev-08 & 42,3 & 1,23 & 28,23 & 4 & 0,43 & 21 & 2,97 & 92,85 & 37 & 2.617 & 28 & 3.299 & 1.135 \\
\hline mar-08 & 56,4 & 2,14 & 44,56 & 4 & 0,45 & 18 & 4,09 & 140,63 & 24 & 3.155 & 9 & 10.086 & 3.620 \\
\hline
\end{tabular}


ANEXO D - ESTUDO ESTATÍSTICO - CEA / IME-USP 